
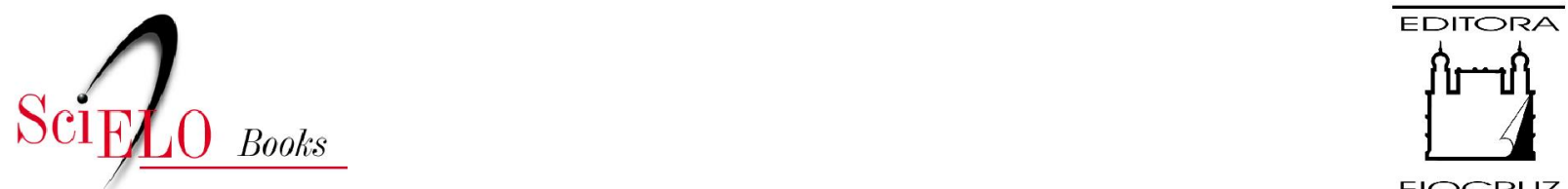

FIOCRUZ

\title{
Raça, Ciência e Sociedade
}

\author{
Marcos Chor Maio \\ Ricardo Ventura Santos \\ (orgs.)
}

MAIO, M.C., and SANTOS, R.V., orgs. Raça, ciência e sociedade [online]. Rio de Janeiro: Editora FIOCRUZ; CCBB, 1996, 252 p. ISBN: 978-85-7541-517-7. Available from: doi:

10.7476/9788575415177. Also available in ePUB from: http://books.scielo.org/id/djnty/epub/maio9788575415177.epub.

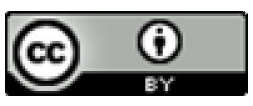

All the contents of this work, except where otherwise noted, is licensed under a Creative Commons Attribution $\underline{4.0 \text { International license. }}$

Todo o conteúdo deste trabalho, exceto quando houver ressalva, é publicado sob a licença Creative Commons Atribição 4.0.

Todo el contenido de esta obra, excepto donde se indique lo contrario, está bajo licencia de la licencia $\underline{\text { Creative }}$ Commons Reconocimento 4.0. 
Raça, Ciência e Sociedade 


\section{FUNDAÇÃO OSWALDO CRUZ}

Presidente

Carlos Médicis Morel

Vice-Presidente de Ensino e Informação

Paulo Marchiori Buss

\section{EDITORA FIOCRUZ}

Coordenador

Paulo Marchiori Buss

Conselho Editorial

Carlos E. A. Coimbra Jr.

Charles Pessanha

Hooman Momen

José da Rocha Carvalheiro

Luiz Fernando Ferreira

Paulo Gadelha

Paulo Marchiori Buss

Sergio Goes de Paula

Zigman Brener

Coordenador Executivo

João Carlos Canossa P. Mendes 
Organizadores:

Marcos Chor Maio

Ricardo Ventura Santos

\section{Raça, Ciência e Sociedade}


Copyright (C) 1996

Todos os direitos desta edição reservados à

EDITORA FIOCRUZ

ISBN: $85.85676-25-6$

Capa:

Danowski Design

Projeto Gráfico e Editoração Eletrônica:

Angélica Mello

Revisão:

Marcionílio Cavalcanti de Paiva

Surpervisão Gráfica:

Walter Duarte

Catalogação-na-Fonte

Centro de Informação Científica e Tecnológica

Biblioteca Lincoln de Freitas Filho

M227r Maio, Marcos Chor (org.)

Raça, ciência e sociedade/Organizado por Marcos Chor Maio,

Ricardo Ventura Santos, - Rio de Janciro: FIOCRUZ/CCBB, 1996. $252 \mathrm{p}$.

Trabalhos apresentados durante seminário: Raça, Ciência e Sociedade no Brasil, realizado no Centro Cultural Banco do Brasil, Rio de Janeiro, 30-31 maio 1995.

1. Raças. 2. Preconceito

CDD. - 20. ed. -305.8

1996

EDITORA FIOCRUZ

Rua Leopoldo Bulhões, 1480 - Térreo - Manguinhos

21041-210 - Rio de Janeiro - RJ

Tel.: (021) 5903789 ramal 2009 Fax: (021) 2808194 


\section{AUTORES \\ Antonio Sérgio Alfredo Guimarães}

(Departamento de Sociologia, UFBA, Bahia)

\section{Carlos Hasenbalg}

(Instituto Universitário de Pesquisas do Rio de Janeiro, IUPERJ, Rio de Janeiro)

\section{Gilberto Hochman}

(Casa de Oswaldo Cruz, Fiocruz, Rio de Janeiro)

\section{Giralda Seyferth}

(Departamento de Antropologia, Museu Nacional, UFRJ, Rio de Janeiro)

\section{Jair de Souza Ramos}

(Departamento de Sociologia e Metodologia das Ciências Sociais, UFF, Rio de Janeiro)

\section{Joel Rufino dos Santos}

(Fundação Cultural Palmares, Ministério da Cultura, Brasília e Universidade Federal do Rio de Janeiro, Rio de Janeiro)

\section{John Manuel Monteiro}

(Departamento de Antropologia, UNICAMP e Centro Brasileiro de Análise e Planejamento, CEBRAP, São Paulo)

\section{Lívio Sansone}

(Departamento de Sociologia, UFBA, Bahia)

\section{Lourdes Martínez-Echazábal}

(University of California at Santa Cruz, California, U.S.A.)

\section{Marcos Chor Maio}

(Casa de Oswaldo Cruz, Fiocruz, Rio de Janeiro)

\section{Maria Arminda do Nascimento Arruda}

(Departamento de Sociologia, USP, São Paulo)

\section{Maria Lúcia de Santana Braga}

(Departamento de Sociologia, UnB, Brasília) 
Nísia Trindade Lima

(Casa de Oswaldo Cruz, FIoCRuy e Universidade Estadual do Rio de Janeiro, UER.J, Rio de Janeiro)

\section{Omar Ribeiro Thomaz}

(Centro Brasileiro de Análise e Planejamento, CIBBRAP. São Paulo)

\section{Ricardo Ventura Santos}

(Museu Nacional. UFRJ e Escola Nacional de Saúde Pública, FlockI\%. Rio de Janeiro)

\section{Yvonne Maggie}

(Instituto de Filosofia e Ciências Sociais, UFR. Rio de Janeiro) 


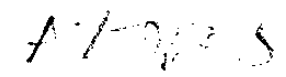

\section{SUMÁRIO \\ PREFi' \\ APRESENT AÇÃO}

Marcos Chor Maio e Ricardo Ventura Santos

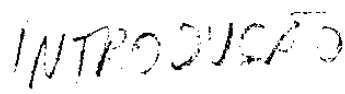

\section{PARTE I: RAÇA, CIÊNCIA E NAÇÃO NA VIRADA DO SÉCULO}

1. As "Raças" Indígenas no Pensamento Brasileiro do Império John Manuel Monteiro.

2. Condenado pela Raça, Absolvido pela Medicina: o Brasil Descoberto pelo Movimento Sanitarista da Primeira República

Nisia Trindade Lima \& Gilberto Hochman 23

3. Construindo a Nação: Hierarquias Raciais e o Papel do Racismo na Política de Imigração e Colonização

Giralda Seyferth

4. Dos Males que Vêm com o Sangue: as Representações Raciais e a Categoria do Imigrante Indesejável nas Concepções sobre Imigração da Década de 20

Jair de Souza Ramos 59

\section{PARTE II: A REINVENÇÃO DA RAÇA NAS DÉCADAS DE 30} E 40

5. Do Saber Colonial ao Luso-Tropicalismo: "Raça" e "Nação" nas Primeiras Décadas do Salazarismo

Omar Ribeiro Thomaz

6. O Culturalismo dos Anos 30 no Brasil e na América Latina: Deslocamento Retórico ou Mudança Conceitual?

Lourdes Martínez-Echazábal

7. Da Morfologia às Moléculas, de Raça à População: Trajetórias Conceituais em Antropologia Física no Século XX

Ricardo Ventura Santos 


\section{PARTE III: O BRASIL COMO "LABORATÓRIO RACIAL": OS ESTUDOS SOBRE RELAÇÕES RACIAIS ENTRE OS ANOS 40 E 60}

8. Cor, Classes e Status nos Estudos de Pierson, Azevedo e Harris na Bahia: 1940-1960

Antonio Sérgio Alfredo Guimarães

9. Roger Bastide: Paisagista

Maria Lúcia de Santana Braga.

10. A Questão Racial no Pensamento de Guerreiro Ramos

Marcos Chor Maio.

11. Dilemas do Brasil Moderno: A Questão Racial na Obra de Florestan Fernandes

Maria Arminda do Nascimento Arruda

\section{PARTE IV: PERSPECTIVAS CONTEMPORÂNEAS ACERCA DA QUESTÃO RACIAL}

12. As Relações Raciais em Casa-Grande \& Senzala Revisitadas à Luz do Processo de Internacionalização e Globalização

Lívio Sansone

13. O Negro como Lugar

Joel Rufino dos Santos

14. "Aqueles a Quem foi Negada a Cor do Dia": As Categorias Cor e Raça na Cultura Brasileira

Yvonne Maggie

15. Entre o Mito e os Fatos: Racismo e Relações Raciais no Brasil

Carlos Hasenbalg. 


\section{APRESENTAÇÃO}

As vinculações entre raça, ciência e sociedade no Brasil, tal como na cultura de diversos outros países ocidentais, é tão antiga quanto multifacetada. Ao analisarmos a trajetória das ciências no Brasil, especialmente a partir do século XIX, defrontamonos repetidamente com exemplos que ilustram a intima e recorrente associação entre tais conceitos. Vejamos alguns deles. Em 1845 o naturalista alemão Karl von Martius publicou no. Jornal do Instituto Histórico e Geográfico Brasileiro um ensaio no qual argumentava que, para se escrever a história do Brasil, era premente abordar as características das três raças que o compunham. quais sejam, dos brancos, índios e negros. Algumas décadas depois, já no início deste século, em 1911, o médico e antropólogo físico João Batista de L acerda, então diretor do Museu Nacional, no Rio de Janeiro, viajou para Londres como representante do Governo brasileiro para apresentar no I Congresso Internacional das Raças um trabalho no qual argumentava que o Brasil mestiço de então estava em processo de branqueamento. Para ilustrar sua proposta, Lacerda lançou mão de uma pintura de Brocos y Gómez, reproduzida na capa deste livro, que para ele encapsulava a "esperança" de que a população brasileira viria a branquear em poucas gerações. Os elementos constitutivos da obra - incluindo expressão, postura, tonalidade da te e disposição espacial dos personagens - veiculam uma mensagem inequívoca, qual seja, a de que a miscigenação na direção "correta" rapidamente alteraria a constituição racial brasileira.' As predições acerca do branqueamento não se concretizaram e na década de 30 os interesses estavam voltados não mais para compreender como havia se processado a diluição e/ou a absorção de uma raça na outra, mas os mecanismos que permitiam uma convivência racial com reduzida taxa de preconceitos no Brasil. Nos anos 50, a "fórmula" (ou "modelo") nacional de articular raça e sociedade tornou-se tema de interesse científico para além das fronteiras do País. Foi quando, no clima do pós-guerra, a UNESCO promoveu diversos estudos sobre as relações raciais no Brasil. Tais investigações colocaram em questão o mito da "democracia racial", especialmente na Região Sudeste, ao darem visibilidade à discriminação racial existente no País. Nesta nossa década de 90 não esvaeceu o interesse pelos imbricamentos entre raça, ciência e sociedade. Particularmente relevantes são as análises de indicadores sociais, tais como renda, educação e saúde, entre outros, que apontam para a persistencia de profundas desigualdades raciais contemporaneamente. Além disso, raça persiste como tema central nas reflexões de caráter histórico ante a relevância do conceito na gênese e desenvolvimento das ciências sociais no Brasil. mento da raça no Brasil: a tese de João Batista de Lacerda ${ }^{\circ}$. Revista do Museu Paulista. n.s. 30:81-98, 1985. 
Os temas mencionados acima são, dentre outros, alguns daqueles analisados nos capítulos que compõem este volume. À medida que se avança na leitura dos textos percebe-se que, longe de se constituírem em fatos isolados, as questões levantadas pelos autores inserem-se num arcabouço maior. qual seja, a longa e recorrente associação entre raça, ciência e sociedade no Brasil.

Esta coletânea teve como ponto de partida o seminário "Raça. Ciência e Sociedade no Brasil", realizado no Centro Cultural Banco do Brasil. Rio de Janeiro, em 30 e 31 de maio de 1995. Por motivos diversos, nem todos os participantes do evento puderam colaborar com este livro. Visando preencher certas lacunas. convidamos posteriormente alguns autores para se unirem a nós na reflexão sobre o tema em apreço (Nísia Trindade Lima, Gilberto Hochman, Jair de Souza Ramos e Maria Lúcia Braga). Três foram os objetivos fundamentais do seminário. que se refletem na composição deste volume. Primeiro, abordar os temas da raça e das relações raciais a partir de uma perspectiva diacrônica, desde o século XIX até o presente, com o intuito de observar as mudanças e deslocamentos conceituais de forma abrangente. Segundo, apresentar um conjunto de trabalhos elaborados a partir de reflexões em diversos campos do conhecimento (antropologia. sociologia, história. ciência politica e literatura), revelando assim a pluralidade de enfoques através dos quais a tríade raça, ciência c sociedade tem sido abordada. Terceiro, fornecer subsídios para a compreensão do cenário racial brasileiro contemporâneo.

O livro está organizado em quatro seções e quinze capítulos.

A primeira seção, constituída de quatro capítulos, discute as relações entre raça. ciência e nação da virada do século XIX até os anos vinte deste. Esta parte inclui análises de John Monteiro. Nísia Trindade Lima, Gilberto Hochman. Giralda Seyferth e Jair de Souza Ramos, que demonstram que reflexões sobre índios, negros, imigrantes, política imigratória, colonização e saúde pública foram matérias obrig̣atórias para as diversas definições de identidade nacional. Os artigos revelam as oscilações presentes à época entre enfoques mais afeitos ao determinismo racial e aqueles que se esforçavam em relativizar a importância da raça e do meio sobre a formação de constructos raciais.

A segunda seção traz três capítulos que tratam dos deslocamentos ocorridos no âmbito do conceito de raça a partir das décadas de 30 e 40. Sem a pretensão de estabelecer marcos cronológicos rígidos, observa-se que tanto no campo da cultura (I ourdes Martínez-Echazábal), da biologia/antropologia física (Ricardo Ventura Santos) ou mesmo da política - via lusotropicalismo - (Omar Ribeiro Thomaz) ocorreram mudanças não destituídas de importância do conceito de raça para o de cultura, ou de raça para população no caso específico da antropologia física. Os textos procuram não somente incorporar o debate e as experiências internacionais, mas também se indagam quanto a vigência de fato do cancelamento das matrizes anteriores de cunho racialista e os limites dos deslocamentos ocorridos.

A terceira parte é composta de quatro capítulos que têm como eixo central a produção de sociólogos e antropólogos nacionais e estrangeiros sobre as relações raciais no Brasil entre as décadas de 40 e 60 . Reúne contribuições de Maria Lúcia Braga, Antonio Sérgio Guimarães, Marcos Chor Maio e Maria Aminda Arruda. A parte mais substantiva dessa produção acadêmica foi elaborada no momento em que o Brasil era visto como um "laboratório" para a "experimentação" e entendimento positivo das interações raciais. 
Neste sentido, as análises têm como referência central os trabalhos realizados sob patrocínio da UNisco no início dos anos 50.

Finalmente, a quarta seção reúne quatro capítulos que se lançam num esforço abrangente de releitura da produção sociológica te antropológica anteriores, ante os desafios do momento presente. Neste sentido os temas do racismo e das desigualdades raciais (Carlos Hasenbalg), do complexo sistema de categorização de cores e raças pela cultura brasileira (Yvonne Maggie) e a atualidade de (iilberto Freyre ou Guerreiro Ramos (Lívio Sansone e Joel Rufino dos Santos, respectivamente) são alguns dos pontos de partida para a compreensão do dilema racial brasileiro e sua inserção no contexto internacional.

Agradecemos aos autores pela paciência e presteza exercitadas ao longo do processo de elaboração deste volume. Também à equipe do Centro Cultural Banco do Brasil, cujos esforço e apoio toram imprescindiveis não só para a realização do seminário "Raça. Ciência e Sociedade no Brasil". como também para a concretização deste projeto editorial. Finalmente, à equipe da Editora Fiocruz. pelo enorme interesse e empenho ao longo do processo de feitura deste livro.

Marcos Chor Maio e Ricardo Ventura Santos 


\section{Parte I}

\section{RAÇA, CIÊNCIA E NAÇÃO NA VIRADA DO SÉCULO}




\title{
1 AS "RAÇAS" INDÍGENAS NO PENSAMENTO BRASILEIRO DO IMPÉRIO
}

\author{
John Manuel Monteiro
}

\section{INTRODUÇÃO}

No dia 29 de julho de 1882, com a presença do Imperador D. Pedro II, foi inaugurada a primeira Exposição Antropológica Brasileira, organizada pelo Museu Nacional. Voltada quase exclusivamente para os aspectos históricos, etnográficos e antropológicos da presença indígena no Brasil, chamava a atenção o contraste entre a enorme importância que se dava às origens indígenas do País e o perfil manifestamente negativo que se traçava dos indios da atualidade, representados por um pequeno grupo de Botocudos, exibidos ao vivo no meio de cerâmicas e artefatos arqueológicos. Neste inusitado encontro entre os freqüentadores do Museu - tão acostumados com os índios da literatura, ou com aqueles que povoavam as páginas das revistas literárias e históricas ou, quando muito, com os embarcadiços da marinha e as pequenas comitivas que buscavam audiência com o Imperador - e os selvagens Botocudos, não se sabe quem se espantou mais. Uma charge irônica da Revista llustrada, após lembrar que se tratava de "comedores de gente". retratou bem a situação: "Mas quem diria? Esses antropófagos é que ficaram com medo de serem devorados pela curiosidade pública', I'

Tema de presença constante no pensamento brasileiro do século XIX, o contraste entre o índio histórico, matriz da nacionalidade, tupi por excelência, extinto de preferência. e o índio contemporâneo, integrante das "hordas selvagens" que erravam pelos sertões incultos, ganhava, pouco a pouco, ares de ciência. A Revista da Exposição Anthropologica, compilada por Mello Morais Filho para o evento, apresentava um cardápio realmente diversificado, dosando ponderações históricas, etnográficas, lingüísticas e - o prato principal, do ponto de vista do Museu Nacional - antropológicas que, na época, dizia respeito às características físicas e morais das raças humanas. Para Ladislau Netto, Diretor do Museu, em seu discurso dirigido ao Imperador quando da abertura da Exposição, esta havia sido organizada com "o fito de soerguer o Império do Brasil ao nível da intelectualidade universal, na máxima altura a que pode ela atingir além do Atlântico e nas extremas luminosas ao norte do continente americano". Como conciliar este nobre intuito com o "fato" de que a parcela mais brasileira da população - a indígena encontrava-se no "maior grau de inferioridade (...) sob o ponto de vista moral e intelectual" (Revista, 1882:2), constituiu-se num desafio para o qual a ciência tinha uma resposta, no mínimo, ambígua.

Revista llustrada, 5/8/1882. Às ilustrações. que são reproduzidas em Schwarcz (1993:76-77), acrescenta-se um texto bastante divertido, assinado por "Julio I). ". noticiando a abertura do evento. 


\section{O ÍNDIO BRASILEIRO PERANTE AS TEORIAS RACIAIS}

Quando, em 1843, o naturalista alemão Carl F. P. von Martius apresentou o ensaio vencedor do concurso do recém-constituído Instituto Histórico e Geográfico Brasileiro, fixando a pedra fundamental da fábula das três raças, conhecia-se muito pouco sobre o Brasil indígena. De fato, um dos principais desafios na construção de uma história nacional residia em localizar, recuperar e divulgar os relatos que davam conta dos aspectos históricos e etnográficos das sociedades indígenas, ainda inéditos em sua vasta maioria. Tal tarefa foi enfrentada não apenas pelo próprio Instituto, através de sua revista trimestral, como também por numerosas revistas literárias e políticas que animavam a vida intelectual da Regência e do Segundo Reinado. Nesses anos, a produção do saber etnográfico também caminhava de mãos dadas com a emergente literatura nacional: poctas e romancistas fundamentavam suas obras indianistas a partir de uma vasta familiaridade com a etnografia.

Von Martius falava em três raças, porém, no contexto brasileiro, este termo enquanto conceito científico ainda cra pouco desenvolvido no período, confundindo-se de certo modo com o conceito de nação. Mesmo antes da penetração definitiva de teorias e técnicas para o estudo das raças, os estudos etnográficos dos meados do século XIX estabeleceram algumas questões de fundo que acabaram condicionando o consumo das teses estrangeiras referentes às raças humanas. Um primeiro condicionante, nada mais que uma elaboração em cima dos tratados, crônicas, cartas, legislação e outros documentos dos primeiros séculos da colonização, diz respeito à construção do Tupi e de seu contraponto, quase sempre definido a partir da negação - o não Tupi -, o Tapuia. Este binômio, recurso que tornava minimamente compreensível a diversidade cultural e lingüística que marcava o Brasil indígena, ganhava novos sentidos no contexto do século XIX. O Tupi representava a matriz da nacionalidade, posto que foram as alianças e a mestiçagem luso-tupi que consolidaram a presença portuguesa na América e que estabeleceram os primeiros troncos de famílias brasileiras. A língua geral, ou nheengatu, ainda falada pelos mais fićis representantes da brasilidade - os caboclos, caipiras e curibocas - foi cultivada pelos intelectuais oitocentistas, inclusive D. Pedro II, como a verdadeira lingua nacional: na introdução à já referida Revista da Exposição Anthropologica, Ladislau Netto lembrava que o "próprio soberano brasileiro (...) se há consagrado em horas de lazer ao estudo acurado da extensa língua guarano-tupí, ou língua geral da América austral cisandina" (Revista, 1882:vii).

Para os pensadores do Império, os índios Tupis, relegados ao passado remoto das origens da nacionalidade, teriam desaparecido enquanto povo, porém tendo contribuído sobremaneira para a gênese da nação, através da mestiçagem e da herança de sua língua. Já os Tapuias, a despeito de enormes evidências históricas em contrário, situavam-se num pólo oposto. Frequientemente caracterizados como inimigos ao invés de aliados, representavam, em síntese, o traiçoeiro selvagem dos sertões que atrapalhava o avanço da civilização, ao invés do nobre guerreiro que fez pacto de paz e de sangue com o colonizador. Se esta última opção custou aos Tupis a sua sobrevivência enquanto povo, a recusa dos outros garantiu-lhes a sobrevivência até o século XIX. Foi, a princípio, neste volátil contexto que marcou o processo de construção de uma identidade nacional, onde se contrapunha índios históricos aos atuais, índios assimiláveis aos recalcitrantes, que as teorias raciais dialogavam com o pensamento brasileiro. 
Deve-se ressaltar, contudo, pelo menos dois outros fatores que também condicionaram a penetração de doutrinas raciais. Um primeiro fator, que de certo modo espelhava o modelo bipolar Tupi-Tapuia, decorria da política indigenista do Império. Desde o período português, as demandas conflitantes de diferentes agentes coloniais geravam uma tensão entre políticas assimilacionistas e repressivas. Com as mudanças institucionais da década de 1840, envolvendo a instalação de diretorias gerais e o apoio estatal à formação de missões capuchinhas, aflorava novamente uma situação de tensão. Tanto nos recintos elegantes das academias e institutos das capitais, quanto nos recantos rústicos dos sertões do Império, as disputas entre os que defendiam a "catequese e civilização" dos índios e aqueles que promoviam a sua remoção e mesmo extermínio intensificavam-se cada vez mais. Neste contexto, as doutrinas raciais - que pregavam a inerente inferioridade dos índios, a impossibilidade dos mesmos atingirem um estado de civilização e, por fim, a inevitabilidade de seu desaparecimento da face da terra - teriam um lugar de destaque no debate em torno da política indigenista. ${ }^{2}$

Segundo, não se pode menosprezar a importância da abolição, em 1850, do tráfico negreiro e a lenta extinção da escravidão no Brasil para o debate indigenista. Embora tenha se tornado lugar comum na historiografia brasileira a afirmação de que a mão-deobra indígena pouco contribuiu para a formação econômica do País, houve fortes defensores da substituição do escravo africano pelo trabalhador indígena, tanto na colônia quanto no Império. É curioso notar, por exemplo, no volume preparado pelo governo brasileiro oferecendo um retrato do País para a Exposição Centenária de Filadélfia, realizada em 1876, que se estimava em um milhão o número de "selvagens que vagueam pelos sertões", e que este número não figurava no primeiro censo nacional, de 1872. Esta pequena informação fazia parte do capítulo "Catechese", provavelmente redigido por Couto de Magalhães, cuja proposta civilizatória incluía o aproveitamento da mão-de-obra indígena na produção da riqueza nacional, diante de um sistema escravista que definhava (Império, 1875:424-426). ${ }^{3}$

As teses raciais passaram a permear esta discussão, colocando em causa a potencialidade não apenas do índio, como também dos mestiços, dos descendentes de escravos e dos próprios ex-escravos, diante da propalada superioridade de imigrantes brancos. Tais questões alimentavam uma parcela significativa do pensamento social brasileiro no ocaso do Império e no início da República e ocupavam, neste mesmo período, a agenda dos cientistas então abrigados nos museus de história natural e nas academias de medicina. ${ }^{4}$

Sobre a persistência da tensão entre distintas vertentes do pensamento indigenista brasileiro, Castro Faria (1993:68-70) aponta para a atualização da polêmica Varnhagen-Lisboa na própria Revista da Exposição Anthropologica, onde se pode contrastar a visão pessimista dos cientistas do Museu com o otimismo de $\mathrm{J}$. Serra quanto à catequese dos índios. Esta mesma tensão se manifesta no catálogo enviado à exposição de Filadélfia (Império, 1875). O contexto geral do debate e suas implicações para a política e legislação indigenistas é mapeado em Carneiro da Cunha (1992).

Deve-se ressaltar, no entanto, que o tom predominante do material propagandístico enviado pelo Império para as exposições internacionais apresentava um país atraente para os imigrantes e apto para os investimentos estrangeiros. Sobre este "gênero de literatura", veja-se o excelente ensaio de Castro Faria (1993). 


\section{O PESSIMISMO DA CIÊNCIA}

Sobretudo a partir do último quartel do século XIX, uma abordagem racial do Brasil indígena começou a fincar pé nos círculos científicos e intelectuais do País. Pode-se afirmar que, sob certo ponto de vista, havia um consenso em torno de uma espécie de padrão evolucionista, onde os índios "remanescentes" constituíam uma "raça" - ou mesmo um conjunto de "raças" - em vias de extinção. No entanto, os usos e abusos do conceito de raça eram bem variados desde o princípio. Para uma vertente do pensamento imperial, apoiando-se na literatura científica de origem européia sobre "raças antropológicas" e "raças históricas", uma enorme gama de atributos positivos das "raças" nativas concorria, através da mestiçagem, para a formação do povo brasileiro, dando um caráter específico a esta nação. ${ }^{5}$ Para outra, também lançando mão da literatura científica estrangeira, foram antes os atributos negativos dessas mesmas "raças" - sobretudo a sua inferioridade moral, física e intelectual - que justificavam e autorizavam a exclusão dos índios do futuro da nação, inclusive por meios violentos.

O que estava em jogo, evidentemente, era a caracterização do Brasil enquanto país civilizado ou, pelo menos, como um país capaz de superar o atraso e as contradições para alcançar um lugar ao lado das luminosas civilizações do hemisfério norte. Intrinsecamente amarrada aos problemas do índio e da escravidão, a perspectiva de se atingir tal estado dependia, em última instância, da incorporação ou da eliminação (e substituição, no caso dos escravos) destes elementos. No entanto, pelo menos enquanto ainda vigorava a escravidão, o debate em torno das idéias de "raça" e "civilização" fixava-se prio-
ritariamente no índio.

Ao abordar "o declínio do bom selvagem" no pensamento europeu e norte-americano, George Stocking Jr. ressalta como o próprio conceito de "civilização" se transformou no decorrer do século XIX, com o surgimento de novos discursos científicos sobre as raças humanas. Se, para uns, era este o destino comum de toda a humanidade, para outros tornou-se um estado ao alcance de algumas "raças". O recorte pessimista dos teóricos que postulavam a impossibilidade de certas raças atingirem a civilização confirmava-se nas próprias circunstâncias históricas da expansão européia, com o rápido desaparecimento de diversas sociedades primitivas nas Américas e no Pacífico Sul (Stocking
Jr., 1968:35-41).

No Brasil, com a penetração das novas idéias, aprofundou-se a vertente pessimista que prognosticava a extinção total dos índios. Na obra de von Martius, ainda na primeira metade do século XIX, a sentença é dura, sem possibilidade de comutação da pena: "[a raça vermelha] traz já visível o gérmen do desaparecimento rápido" (Martius, 1982[1845]:70). De forma mais meticulosa, os primeiros antropólogos do Museu Nacio-

O principal expositor desta vertente foi o Gal. Couto de Magalhães, cuja obra teve uma influência muito profunda sobre setores do pensamento nacionalista no País. Vide Machado (1996) para uma discussão

De fato, é notável que, num País tão marcado pela instituição escravista, a escravidão entrava com pouquíssima frequêencia na pauta das discussões e das matérias publicadas pelo Instituto Histórico Brasileiro, ao passo que a preocupação - histórica e etnográfica - com os indios, de certo modo, predominava sobre
outros assuntos. 
nal e, um pouco mais tarde, do Museu Paulista, aprofundaram esta perspectiva com base nos conhecimentos produzidos pela antropologia física. ${ }^{7}$

Verdadeiros pioneiros, João Batista de Lacerda Filho e seus colaboradores no Museu Nacional iniciaram, a partir da década de 1870 , a pesquisa sistemática das "raças indígenas" do Brasil, divulgando suas conclusões através dos Arquivos do Museu Nacional e, de forma mais pública, na própria Exposição Antropológica de 1882. Inspirados nos "moderníssimos estudos" de Paul Broca, Armand de Quatrefages e Paul Topinard, entre outros, denunciavam o atraso na produção do conhecimento sobre os "caracteres físicos das raças indígenas", em comparação com o enorme acervo de crânios organizado pelo poligenista Samuel Morton na Universidade de Pennsylvania ou, ainda, as investigações craniométricas do antropólogo argentino Moreno sobre os nativos da Patagônia (Lacerda $\mathrm{F}^{\mathcal{Q}} \&$ Peixoto, 1876:47).

Apesar do tamanho reduzido da amostragem empregada pelos pesquisadores brasileiros - seis crânios Botocudos, um de um índio de Macaé, um da llha do Governador, um do sítio arqueológico da Lagoa Santa e um último proveniente do Ceará - os autores de um primeiro artigo nos Arquivos adiantaram uma série de conclusões que ilustram o quanto, também no Brasil, a ciência servia para confirmar noções preconcebidas sobre a inferioridade dos não europeus. A análise dos seis crânios da primeira série autorizava a seguinte afirmação:

Pela sua pequena capacidade craniana, os Botocudos devem ser colocados a par dos Neo-Caledônios e dos Australianos, isto é, entre as raças mais notáveis pelo seu grau de inferioridade intelectual. As suas aptidões são, com efeito, muito limitadas e dificil é faze-los entrar no caminho da civilização. (Lacerda Fo \& Peixoto, 1876:71-72)

O segundo tipo de crânio examinado, um único exemplar de um sítio em Macaé, pelas suas características físicas representava "um produto de cruzamento muito adiantado e nele existem caracteres que indicam um certo grau de superioridade intelectual relativamente aos crânios da primeira série [isto é, dos Botocudos]' . De fato, como o crânio foi retirado de um contexto arqueológico onde se encontrou também uma espada portuguesa, "podemos, portanto, suspeitar que o cruzamento aqui se fez com o tipo europeu".

Os autores também estabeleceram a superioridade do crânio encontrado na Ilha do Governador, para eles provavelmente de um "Tamoio subdolicocéfalo", ou seja, de um Tupi histórico, por assim dizer. Apesar de compartilhar certos traços com os crânios botocudos, deste crânio tamoio foi possível especular o seguinte: "Os Tamoios, portanto, a julgar por este espécime, não eram de todo semelhantes aos Botocudos e neles já se tinha modificado um pouco o tipo primitivo", 8

A última prova, envolvendo um crânio da Lagoa Santa, rebaixava mais ainda os pobres Botocudos. A capacidade cefálica deste crânio, de $1388 \mathrm{cc}$, ao mostrar-se superior a dos crânios botocudos, "leva-nos a admitir que no decurso de muitos séculos, a raça

Neste texto, atenho-me à discussão no âmbito do Império. Sobre o debate em torno dos Kaingang paulistas nos anos iniciais da República, vide Monteiro (1992) e Lima (1989).

8 Implícito aqui é o argumento de que os Tamoios constituíam uma das "raças" formadoras da população do Rio de Janeiro e, portanto, era necessário distanciá-los histórica e racialmente dos Botocudos, execrados e excluídos no projeto de mistura de raças. Para uma abordagem destes temas no contexto paulista, onde os Kaingang entravam no papel dos Botocudos, vide Monteiro (1992). 
dos Botocudos não tem subido um só grau na escala da intelectualidade" (Lacerda $F^{Q} \&$ Peixoto, 1876:72-73).

A postura dos cientistas do Museu Nacional revelava-se de forma mais explícita na Revista da Exposição Anthropologica. Em suas " Observações relativas à teoria da evolução", provenientes de uma conferência lida na Sociedade Científica de Buenos Aires, Ladislau Netto declarou:

E perdoai-me senhores, se vos pareço exagerado no que vos aqui exponho, mas deveis confessar que, estudados detidamente os organismos na sua ascendência gradual, e bem apreciadas as qualidades superiores que logrou adquirir a raça indogermânica, máxima expressão do aperfeiçoamento humano, como que achamos maior diferença entre os mais cultos e os mais imperfeitos e bestiais individuos humanos, do que entre estes últimos e os gorilas e chimpanzés. (Revista, 1882:113)

Por seu turno, João Batista Lacerda desejava mostrar o lado útil das experiências científicas no estudo dos índios brasileiros. Retomando uma velha discussão sobre a suposta superioridade da força física do selvagem, o Dr. Lacerda negou a asserção a partir de testes realizados em três adultos do sexo masculino, um Xerente e dois Botocudos, utilizando o "dinamômetro de Mathieu" para medir a força. ${ }^{9}$ Estes selvagens, mostrando uma tendência à fadiga, não conseguiram atingir os mesmos índices dos "indivíduos civilizados da raça branca, de musculatura medíocre e que jamais se tinham entregado a trabalhos braçais" - provavelmente funcionários do próprio Museu, que participaram de outros testes comparativos. Se as conclusões são bastante óbvias, o Dr. Lacerda fez questão de explicitá-las:

A conseqüencia importante deste fato seria - que o nosso indigena, mesmo civilizado, não poderia produzir a mesma quantidade de trabalho útil, no mesmo tempo, que os indivíduos de outra raça, especialmente da raça negra (...) O indio não poderia substituir o negro como instrumento de trabalho (...) Eis ai como de um problema antropológico deduz-se um problema econômico e industrial, o que mais uma vez demonstra que a antropologia não é uma ciência meramente especulativa, mas que ela é susceptivel de ter aplicações práticas e úteis. (Lacerda Fo, 1882:6-7)

\section{CONSIDERAÇÕES FINAIS}

Na segunda metade do século XIX, a penetração de novas idéias sobre raça e evolução encontrava um campo já armado no que diz respeito ao debate sobre os índios no Brasil. Longe de sustentarem uma política única, concebivelmente conivente com a violência premeditada que fazia dos índios objetos de extermínio, os pressupostos raciais tiveram que dialogar com um contradiscurso que via no índio não apenas as raízes da nacionalidade, como também um caminho para o futuro da civilização brasileira, sobretudo através do processo de mestiçagem.

Ainda assim, mesmo os mais dedicados defensores dos índios tendiam a concordar que os mesmos haviam de desaparecer, porém não necessariamente pelos defeitos da

9 Segundo Ricardo Ventura Santos, este aparelho é parte do acervo do Setor de Antropologia Biológica do Departamento de Antropologia do Museu Nacional, Rio de Janeiro. 
raça. Couto de Magalhães, em trecho d'O Selvagem dedicado às raças indígenas e mestiças, buscou reverter o pessimismo que a antropologia suscitava na época:

Não devemos conservar, pois, apreensões e receios a respeito dos futuros habitantes do Brasil. Cumpre apenas não turbar, partindo de prejuízos de raças, o processo lento, porém sábio, da natureza. Nosso grande reservatório de população é a Europa; não continuamos a importar africanos; os indigenas, por uma lei de seleção natural, hão de cedo ou tarde desaparecer; mas se formos previdentes e humanos, eles não desaparecerão antes de haver confundido parte do seu sangue com o nosso, comunicando-nos as imunidades para resistirmos à ação deletéria do clima intertropical que predomina no Brasil. (Magalhães, 1975 [1876]:73)

\section{AGRADECIMENTOS}

O autor agradece as críticas e sugestões de Maria Helena P. T. Machado, Antonio Carlos de Souza Lima, Miriam Dolhnikoff, Ângela Alonso, Omar Ribeiro Thomaz e Emília Pietrafesa de Godoi.

\section{REFERÊNCIAS BIBLIOGRÁFICAS}

CARNEIRO DA CUNHA, M., 1992. Política indigenista no século XIX. In: História dos Índios no Brasil (M. Carneiro da Cunha, org.), pp. 133-154, São Paulo: Companhia das Letras.

CASTRO FARIA, L., 1993. Antropologia: Espetáculo e Excelência. Rio de Janeiro: Editora UFRJ.

IMPÉRIO, 1875. O Imperio do Brazil na Exposição Universal de 1876 em Philadelphia. Rio de Janeiro: Typographia Nacional.

LACERDA Fo, J. B. \& PEIXOTO, R., 1876. Contribuições para o estudo anthropológico das raças indígenas do Brazil. Archivos do Museu Nacional, 1:47-75.

LACERDA Foo, J. B., 1882. A força muscular e a delicadeza dos sentidos dos nossos indígenas. Revista da Exposição Anthropologica, pp. 6-7.

LIMA, A. C. S., 1989. Os museus de história natural e a construção do indigenismo. Revista de Antropologia, 30-32:277-230.

MACHADO, M. H. P. T., 1996. Um país em busca de moldura: o pensamento do General Couto de Magalhães, o selvagem e os sertões. In: Confronto de Culturas (J. Monteiro \& F. Azevedo, orgs.), São Paulo: Edusp e Rio de Janeiro: Expressão e Cultura (no prelo).

MAGALHÃES, J. V. C., 1975 [1876]. O Selvagem. São Paulo: Edusp e Belo Horizonte: Itatiaia

MARTIUS, C. F. P. von, 1982 [1845]. O Estado de Direito entre os Autóctones do Brasil. São Paulo: Edusp e Belo Horizonte: Itatiaia.

MONTEIRO, J. M., 1992. Tupis, Tapuias e a história de São Paulo. Revisitando a velha questão Guaianá. Novos Estudos Cebrap, 34:125-35.

REVISTA, 1882. Revista da Exposição Anthropologica (Mello Morais Filho, org.), Rio de Janeiro: Typ. Ribeiro \& C. 
SCHWARCZ, L. K. M., 1993. O Espetáculo das Raças. Cientistas, Instituições e Questão Racial no Brasil, 1870-1930. São Paulo: Companhia das Letras.

STOCKING Jr., G., 1968. Race, Culture and Evolution. Essays in the History of Anthropology. Chicago: University of Chicago Press. 


\title{
2 CONDENADO PELA RAÇA, ABSOLVIDO PELA MEDICINA: O BRASIL DESCOBERTO PELO MOVIMENTO SANITARISTA DA PRIMEIRA REPÚBLICA
}

\author{
Nísia Trindade Lima \& Gilberto Hochman
}

\section{INTRODUÇÃO}

\begin{abstract}
Respiramos hoje com mais desafogo. O laboratório dá-nos o argumento por que ansiamos. Firmados nele contraporemos à condenação sociológica de Le Bon a voz mais alta da biologia. (In: Problema Vital, Lobato, 1918)
\end{abstract}

Essa passagem de Monteiro Lobato revela o alívio de parte significativa da intelectualidade brasileira nos anos de 1910. Afinal, a ciência experimental oferecia uma saída para o drama vivido por alguns brasileiros: teríamos sido condenados, pelo nosso estoque racial e pelo clima tropical da pátria, à eterna inferioridade e improdutividade? A resposta da biologia, da medicina moderna, indicava que não. Os conhecimentos dos médicos-higienistas sobre a saúde dos brasileiros e sobre as condições sanitárias em grande parte do território nacional, revelados ao público em meados da década de 1910, nos absolviam enquanto povo e encontravam um novo réu. $\mathrm{O}$ brasileiro era indolente, preguiçoso e improdutivo porque estava doente e abandonado pelas elites políticas. Redimir o Brasil seria saneá-lo, higienizá-lo, uma tarefa obrigatória dos governos.

O alívio expresso por Monteiro Lobato - "O Jeca não é assim: está assim" - refletia a campanha de um amplo e diferenciado movimento político e intelectual que, de 1916 a 1920, proclamou a doença como principal problema do País e o maior obstáculo à civilização. O movimento pelo saneamento do Brasil, pelo saneamento dos sertões, concentrou esforços na rejeição do determinismo racial e climático e na reivindicação da remoção dos principais obstáculos à redenção do povo brasileiro: as endemias rurais.

Este trabalho discute as principais formulações do movimento pela reforma da saúde pública na Primeira República, concentrando-se na sua interpretação do Brasil como país doente e nas suas sugestões em termos de políticas de saúde e saneamento a serem implementadas para a superação do quadro sanitário vigente. Nossa hipótese é que este movimento teve um papel central e prolongado na reconstrução da identidade nacional a partir da identificação da doença como o elemento distintivo da condição de ser brasileiro. Para o movimento pelo saneamento do Brasil, a redenção nacional demandava ações centralizadas, nacionais e tecnicamente autônomas, que legitimariam o crescimento do papel do Estado brasileiro no campo da saúde pública. 
Nas partes seguintes deste trabalho, discutiremos o contexto histórico e intelectual do movimento, a sua interpretação sobre o País, as soluções apontadas e as repercussões e impactos políticos da campanha pelo saneamento do Brasil.

\section{CONTEXTO DA CAMPANHA DO SANEAMENTO DO BRASIL}

"O Brasil é um imenso hospital". A denúncia feita pelo médico e professor da Faculdade de Medicina do Rio de Janeiro, Miguel Pereira, em outubro de 1916, tornou-se um emblema das posições críticas à ordem social e política da Primeira República. Esta frase é apontada como marco de origem da campanha do saneamento rural e sua contextualização contribui para a melhor compreensão desse movimento. ${ }^{1}$

A célebre frase contestava o pronunciamento de um deputado federal que declarara estar disposto, em caso de invasão estrangeira, a ir aos sertões e convocar os caboclos para defender o País. É importante observar que ela foi proferida em discurso de saudação a Aloysio de Castro, diretor da Faculdade de Medicina do Rio de Janeiro, pelo êxito da delegação brasileira em congresso médico realizado em Buenos Aires. A imagem do Brasil como hospital foi retomada por Miguel Pereira na homenagem prestada ao cientista e membro da delegação, Carlos Chagas. No caso da segunda homenagem, o orador acentuou a importância da descoberta da endemia rural que grassava em extensas áreas do território brasileiro: a tripanossomíase americana, doença mais conhecida como mal de Chagas.

A expressiva imagem resumiu, dessa forma, importantes elementos que contribuíram para o deflagrar da campanha pelo saneamento rural: o debate nacionalista intensificado com a Primeira Guerra Mundial, o impacto das viagens e descobertas científicas do Instituto Oswaldo $\mathrm{Cruz}^{2}$ e as críticas à decadência da experiência republicana.

Ao se opor ao deputado que via na força do sertanejo um elemento de soberania nacional, Miguel Pereira expressava um debate mais amplo concernente à imagem da nação e de seu povo. De fato, o período da Primeira Guerra Mundial e do imediato pósguerra foi, no exterior e no Brasil, marcado por intensa atuação de movimentos de caráter nacionalista que pretendiam descobrir, afirmar e reclamar os princípios da nacionalidade e realizá-lo através do Estado Nacional (Joll, 1982; Hobsbawn, 1991). Há inúmeras indicações sobre como guerras, em geral problemas de recrutamento e derrotas militares, geraram debates e polêmicas sobre determinismo e melhoria racial, nas quais as condições de saúde tiveram papel relevante (Porter, 1991).

No caso brasileiro, esses movimentos vislumbraram vários caminhos para a recuperação e/ou fundação da nacionalidade: recrutamento militar e profissionalização do Exército; alfabetização; saúde; culto ao civismo; ampliação do colégio eleitoral, entre outros (Skidmore, 1976; Oliveira, 1990). Organizados sob a forma de ligas, reuniram re-

Os principais trabalhos a abordar a campanha do saneamento rural foram realizados por Luiz Antonio de Castro Santos $(1985,1987)$ e ressaltam a ideologia de construção da nacionalidade como dimensão mais relevante do movimento. Sobre o tema, vide também Costa (1985) e Labra (1985).

2

O Instituto Oswaldo Cruz sucedeu o Instituto Soroterápico, criado em 1900, na capital federal, durante a epidemia de peste bubônica. Na gestão do cientista Oswaldo Cruz (1903-1917) tornou-se um importante centro de pesquisas e de formação de profissionais especializados em saúde pública. Sobre o papel desse (1993); Luz (1982); Schwartzman (1979) e Stepan (1976). 
presentantes das elites intelectual e política do País. Uma importante tendência que se consolidou progressivamente consistiu em ver nas doenças o problema crucial para a
construção da nacionalidade.

A descoberta da tripanossomíase americana e de suas graves formas clínicas - problemas cardíacos, neurológicos e deformações físicas - trazia uma imagem sobre as populações do interior distinta da idealizada pela literatura romântica. Somada a outras doenças endêmicas, conformava um quadro em que era impossível apostar na vitalidade do caboclo. Miguel Pereira reportava-se, ao proferir sua frase, ao Brasil revelado pelas expedições científicas do Instituto Oswaldo Cruz. ${ }^{3}$

As homenagens a Aloysio de Castro e Carlos Chagas expressaram o congraçamento da elite médica do período, que ocupava os cargos mais importantes da Faculdade de Medicina do Rio de Janeiro e da Academia Nacional de Medicina, em torno da descoberta de um pesquisador do Instituto Oswaldo Cruz. Foi celebrada, naquele momento, como uma vitória que ultrapassou os limites do instituto de pesquisas, transformando-se numa conquista da medicina brasileira. Miguel Pereira lançava, então, uma "cruzada da medicina pela pátria", afirmando que ao médico cabia substituir a autoridade governamental, ausente na maior parte do território nacional (Couto, 1917:13-17 apud Britto, 1995:23).

O papel atribuído ao médico não pode ser dissociado da crítica à República, especialmente dirigida à adoção do federalismo na Carta Constitucional de 1891. O federalismo teria propiciado, na perspectiva de importantes intelectuais do período, a oligarquização da política, consistindo numa solução artificial e incompatível diante do que entendiam ser a realidade brasileira. É a essa linha de crítica que se reporta Miguel Pereira. ${ }^{4}$

Atribuir à ciência, mais especificamente à medicina, o papel-chave numa nova organização nacional, parece sugerir ainda um novo elemento de oposição. De fato, no discurso da elite médica do período, era comum o descontentamento com a subordinação das áreas de educação e saúde ao Ministério da Justiça e Negócios Interiores, visto como uma agência dominada pelos políticos e pelos bacharéis.

A crítica mais importante à forma de atenção à saúde voltava-se para o princípio constitucional de autonomia estadual e municipal, que restringia as possibilidades de uma ação coordenada em âmbito federal. No arranjo federativo cabia aos poderes locais o cuidado com a saúde da população. Ao governo federal competia as ações de saúde no Distrito Federal, a vigilância sanitária dos portos e a assistência aos estados da federação, em casos previstos e regulados constitucionalmente. O órgão federal responsável era a Diretoria Geral de Saúde Pública (DGSP), criada em 1897 como parte da estrutura do Ministério da Justiça e Negócios Interiores.

O relativo consenso sobre a gravidade do quadro sanitário do País pode ser identificado desde os momentos iniciais de atuação da DGSP. Especialmente as epidemias urbanas foram objeto de ações mais sistemáticas com impactos na redefinição das

\footnotetext{
Percorrendo o Brasil nas duas primeiras décadas do século $\mathrm{XX}$, as expedições científicas do Instituto Os-
waldo Cruz desempenharam papel destacado no waldo Cruz desempenharam papel destacado no conhecimento sobre a incidência de doenças e o debate
dos problemas nacionais. Estiveram intimamente bilidade de utilização de potencial econômico de rios como o São Franciaco de ferrovias, avaliações da viade Obras contra as Secas. Vide a respeito Albuquerque et al.(1992). Compartilhavam essa critica expressivos nomes do pensamento socic Oliveira Viana.
} 
atribuições do governo no campo da saúde. Mas é na década de 1910 que os problemas de saúde pública passam a ocupar um lugar central na agenda política do País.

A frase de Miguel Pereira expressou importantes tendências que se manifestavam no Brasil, durante a década de 1910. Partindo dos dados registrados pelas expedições científicas organizadas pelo Instituto Oswaldo Cruz, especialmente no relatório da que foi dirigida pelos médicos Belisário Penna e Arthur Neiva, ela contribuiu para transformar em tema de debate público algo que era discutido em periódicos especializados e nos principais fóruns acadêmicos dos médicos. Sua repercussão na grande imprensa foi intensificada com a publicação, de novembro de 1916 a janeiro de 1917, no jornal Correio da Manhã, de uma série de artigos de Belisário Penna conclamando o País a participar de uma campanha pelo saneamento do Brasil. ${ }^{5}$

Enfatizando a necessidade de recuperar e integrar o País e o homem do interior, a mobilização em torno da idéia do saneamento reuniu progressivamente importantes setores das elites intelectual e política que participaram da criação da Liga Pró-Saneamento do Brasil, em fevereiro de 1918. Foram seus sócios fundadores, entre outros, membros da Academia Nacional de Medicina, catedráticos da Faculdade de Medicina do Rio de Janeiro, cientistas do Instituto Oswaldo Cruz, antropólogos do Museu Nacional, militares, educadores, juristas e o próprio Presidente da República, Wenceslau Brás.

Dirigida pelo seu mais ativo militante, Belisário Penna, a Liga Pró-Saneamento realizou intensa propaganda através de conferências; palestras em escolas, entidades associativas de proprietários rurais e nas Forças Armadas; distribuição de folhetos de educação sanitária, entre outras ações. A repercussão da campanha pelo saneamento foi expressiva na imprensa e nos debates do Congresso Nacional. Outro dado relevante consiste na organização de delegações regionais da entidade em nove estados, considerados, à época, representativos de todas as regiões geográficas do País.

A campanha da Liga tinha como objetivo mais imediato a criação de uma agência pública de âmbito federal que coordenasse efetivamente as ações de saúde em todo o território nacional e superasse os limites que constrangiam a ação da Diretoria Geral de Saúde Pública. A realização desse objetivo supunha a geração de uma consciência nacional que identificasse no abandono e na presença das endemias as características distintivas da população rural brasileira.

\section{BRASIL: UM PAÍS DOENTE}

O debate sobre a identidade nacional ocupou lugar privilegiado no Brasil da Primeira República. Que o País não constituía uma nação era voz corrente: no máximo reunia províncias pouco integradas, transformadas em estados pela constituição republicana de 1891. Nenhum sentimento de nacionalidade era percebido no povo brasileiro. Compartilhando esse diagnóstico, as correntes de pensamento do período diferenciavam-se quanto à crença na viabilidade da construção nacional do país e às imagens de sociedade que idealizavam (Carvalho, 1994). 
Para alguns intelectuais, os obstáculos representados pela base racial eram insuperáveis. Influenciados por teóricos como Gobineau, Agassiz e Le Bon, só viam num programa intenso de imigração uma saída favorável para a nação brasileira. Nessa perspectiva, o grande problema da nacionalidade radicava-se no povo que, no limite, deveria ser substituído (Skidmore, 1976; Carvalho, 1994).

O conteúdo atribuído à palavra raça era muito impreciso e idéias de superioridade racial estiveram presentes mesmo entre os críticos da primeira corrente intelectual mencionada. Entre esses, ainda que muitas vezes de forma ambígua, encontramos posições de crítica à idéia fatalista da inviabilidade do Brasil e de seu povo. Autores como Manoel Bomfim e Alberto Torres podem ser apontados como intelectuais que, nos primeiros anos do século XX, contribuíram para deslocar as teses de determinismo racial e climático, enfatizando dimensões culturais do passado nacional e da organização da sociedade, ao mesmo tempo em que apontavam alternativas para o País. No caso de Alberto Torres, a revisão dos princípios federalistas e o incentivo à pequena propriedade rural e de Manoel Bomfim, um amplo projeto educacional (Bomfim, 1905; Torres, 1914a, 1914b).

Os intelectuais da campanha do saneamento rural aproximavam-se, assim, de uma tendência de crítica às teses de determinismo racial, que se tornou mais visível com o debate sobre a afirmação da nacionalidade brasileira durante a Primeira Guerra Mundial. ${ }^{6}$ Influenciados pelas correntes de pensamento social do primeiro período republicano, não cumpriram apenas o papel de divulgadores de idéias preexistentes; trouxeram para o debate dois novos elementos: a idéia da doença como característica central do povo e a qualificação do isolamento do sertanejo, indicado por Euclides da Cunha, como um estado de abandono da população do interior pelos governos.

Essas imagens alcançavam legitimidade à medida que, como afirmavam, baseavam-se no conhecimento do "Brasil Real", através das viagens científicas, em contraste com a idealização do país característico das análises originárias de informações de gabinete. Duas representações sobre o Brasil consistem no objeto central de sua crítica - a ufanista, que apresentava um retrato otimista e de exaltação do País, e a fatalista, inspirada nas teses de inferioridade racial.

O ufanismo, termo utilizado em estudos recentes para se referir à corrente de pensamento que propunha a autocongratulação dos brasileiros, encontrou sua expressão máxima no livro Porque me Ufano de Meu País, escrito pelo monarquista Conde de Afonso Celso e publicado em 1900 (Oliveira, 1990; Carvalho, 1994). Apesar de tendências de exaltação do País se manifestarem desde o período colonial, a obra de Afonso Celso trazia com mais força um novo elemento: a valorização das três raças. ${ }^{7}$

6 O termo raça aparece de forma muito imprecisa nos textos dos intelcctuais participantes da campanha. Uma discussão mais aprofundada sobre seu significado entre os higienistas brasileiros encontra-se em Stepan (1991). Segundo esta autora, os intelectuais que aderiram ao saneamento rural, e a outros movimentos semelhantes na América Latina, expressavam uma variante das propostas eugenistas, identificada com a higiene pública e compatível com a miscigenação racial.

7 A novidade aqui não está tanto no caráter original da proposta, pois Carl Friedrich von Martius já havia defendido, em sua dissertação para o concurso promovido em 1840 pelo Instituto Histórico e Geográfico Brasileiro (IHGB), a tese de que uma "historiografia filosófica" do País deveria cleger como tema central o encontro das três raças que formavam a populaçâo brasileira. Refcrimo-nos mais, ao falar em novo elemento, ao impacto da proposta para um público mais amplo. 
A imagem positiva do Brasil era também compartilhada pela literatura romântica, que exaltou a natureza e o homem brasileiros. Entre os autores românticos, não encontramos, no entanto, a idéia do encontro das três raças. O brasileiro era representado pelo indígena, num primeiro momento e, posteriormente, pelo caboclo sertanejo, notando-se a ausência quase absoluta do negro (Carvalho, 1994).

Cenário de expressiva literatura no século XIX, o sertão recebe especial atenção da que ficou conhecida como terceira geração de escritores românticos, constituída por José de Alencar, Bernardo Guimarães e Franklin Távora, entre outros autores. Com eles, a ficção romântica consolidou-se sob a forma indianista, sertanista e regionalista (Coutinho, 1978).

Como característica comum à obra dessa geração sobressai a visão idílica das regiões interioranas do Brasil e de seus habitantes - a exuberância da natureza brasileira, o vigor e a bondade inatos nos indígenas e nos sertanejos. O interessante é que essa representação era comum a outros discursos que não o literário, entre os quais merece registro, pelo tema de que se ocupa este trabalho, o da Academia Imperial de Medicina e das teses defendidas na Faculdade de Medicina do Rio de Janeiro. No discurso médico predominante na segunda metade do século XIX, o campo e os sertões eram focalizados como lugar propício à vida saudável e harmoniosa. Em contraste, a cidade revelava-se perigosa - espaço de doenças e vícios.

Um importante ponto de ruptura em face desse imaginário, senão pelo ineditismo, certamente pela repercussão que alcançou, pode ser identificado na obra de Euclides da Cunha, Os Sertões (1902). Nela sobressaem elementos de força e de fragilidade - o sertanejo é um forte, mas é também rude e carente de civilização. Uma das versões mais recorrentes sobre a sociedade brasileira - aquela que acentua o descompasso entre as áreas urbana e rural - tem em Euclides da Cunha um expressivo porta-voz. Em Os Sertões também se destaca a importância do conhecimento empírico do País, o que, como veremos, é uma premissa para os intelectuais que aderem à campanha do saneamento.

A segunda representação do Brasil, contestada pelo movimento, caracteriza-se pela imagem negativa do povo, especialmente da população do interior. Por sua expressividade simbólica e importância para a campanha do saneamento, podemos exemplificá-la através do personagem Jeca Tatu, criado pelo escritor paulista Monteiro Lobato. Em dois artigos publicados no jornal O Estado de São Paulo, em 1914, Lobato defende ser o caboclo a principal praga nacional e o descreve com palavras fortes: "funesto parasita da terra (...) homem baldio, inadaptável à civilização" (Lobato, 1957a:271).

O autor observa, numa crítica à literatura romântica e regionalista, que o indianismo estaria mudando de nome, transformado em caboclismo e sertanismo e, a partir de sua experiência pessoal como fazendeiro, afirma retratar o verdadeiro homem do interior, resumindo sua posição em frases de efeito, tais como: "Pobre Jeca. Como és bonito no romance e feio na realidade" (Lobato, 1957a:292). É curioso pensar como uma representação particular, baseada no trabalhador rural da lavoura decadente do café, transforma-se num novo símbolo de brasilidade. ${ }^{8}$

8 Em certo momento, Lobato precisa a origem de Jeca Tatu. O Jeca era um "piraquara", um caipira, do Vale do Paraíba. Portanto, uma outra imagem de brasileiro, o habitante das zonas de decadência econômica do Sudeste do Pais, diferente do sertanejo abandonado identificado por Penna e Neiva. Para uma análise da obra de Lobato, vide Campos (1986). 
Como outros estudos já observaram, a imagem negativa do caboclo seria alterada através do contato de Monteiro Lobato com lideranças da campanha do saneamento, particularmente com Belisário Penna e Arthur Neiva (Skidmore, 1976; Castro Santos, 1985, 1987). As razões para essa mudança podem ser, ao menos em parte, explicadas pela imagem do Brasil e do povo brasileiro construída pela campanha do saneamento. Opondo-se ao ufanismo e ao determinismo racial fatalista, e qualificando como científica a natureza de sua proposta, seus participantes divulgaram uma nova explicação para as origens dos "males do Brasil",.

A obra $O s$ Sertões é vista como um marco crucial de referência para os intelectuais da campanha do saneamento, que ao tema do isolamento do sertanejo, sugerido por Euclides da Cunha, associam o termo abandono - responsabilizando enfaticamente as elites intelectuais e políticas por essa situação. As viagens científicas pelo interior do Brasil, das quais participaram alguns importantes membros da Liga PróSaneamento, são igualmente por eles apontadas como o ponto de origem de sua interpretação.

A principal referência é a Viagem Cientifica pelo Norte da Bahia, Sudoeste de Pernambuco, Sul do Pará e de Norte a Sul de Goiás, organizada pelo Instituto Oswaldo Cruz, em 1912, por solicitação da Inspetoria de Obras contra as Secas. ${ }^{9}$ Ao relatório dessa viagem referia-se Miguel Pereira no ato considerado o início da campanha do saneamento. A visão do País divulgada no documento é reproduzida numa série de artigos publicados por Belisário Penna no Correio da Manhã e no periódico oficial da Liga PróSaneamento, a revista Saúde. ${ }^{10}$ Estes textos consistem nas fontes privilegiadas para reconstruirmos a imagem do Brasil como um país dominado pela doença.

Percorrendo durante sete meses uma extensa área em que predominavam regiões periodicamente assoladas pela seca, a expedição dirigida por Belisário Penna e Arthur Neiva realizou amplo levantamento das condições climáticas, socioeconômicas e nosológicas, fartamente documentadas através de registro fotográfico (Albuquerque et al., 1992). Ao que parece, as áreas visitadas eram muito pouco e, em alguns casos, praticamente desconhecidas por naturalistas estrangeiros e brasileiros. Segundo dados do relatório, o único naturalista a percorrer a região compreendida entre Parnaguá, no Piauí, e Natividade, em Goiás, fôra George Gardner em 1836 (Penna \& Neiva, 1916).

O relatório, além de informações sobre clima, fauna e flora, apresenta, em detalhes, as doenças que afetavam homens e atividade pecuária. Vários comentários acompanham a apresentação dos dados, muitos com o caráter de recomendações. Tratando-se de um estudo prévio à construção de açudes pela Inspetoria de Obras contra as Secas, seus autores em vários momentos sublinham a ineficácia dessa medida, se tomada isoladamente.

9 No mesmo período em que o Instituto Oswaldo Cruz realizou suas viagens científicas, outras expedições ao interior do Brasil foram organizadas, quer com finalidades cientificas, quer estratégicas e, muitas vezes, reunindo ambas. Pela vinculação de seus participantes à campanha do saneamento rural, merece registro o da Comissão de Linhas Telegráficas Estratégicas de Mato Grosso ao Amazonas, mais conhecida como Comissão Rondon, que percorreu esses estados em 1907 e 1908.

10 Foram publicados oito números da revista, quatro em 1918 e quatro em 1919. Sua leitura indica grande diversidade de temas, que iam da etiologia e profilaxia de doenças a assuntos políticos e pedagógicos. Para uma análise desse periódico, vide Britto \& Lima (1991). 
A posição fica clara no debate sobre as medidas de combate à malária, uma das doenças mais disseminadas nas proximidades do São Francisco e outros rios. Os autores são enfáticos em destacar a necessidade de ações profiláticas que impedissem a associação perversa entre disponibilidade de água e foco de doenças. Deixando os pormenores de lado, se tentarmos destacar o que aparece como argumento mais forte ao longo do relatório, teríamos que apontar a idéia do abandono da população do "Brasil Central",

Era uma população abandonada e esquecida que, ainda que vitimada por doenças, poderia, em algumas regiões, como viram em áreas da Bahia e de Pernambuco, apresentar-se robusta e resistente. O cenário apresentava-se de fato "dantesco' onde era alarmante o número de portadores da doença de Chagas, especialmente em localidades do Estado de Goiás. Dessa forma, a leitura do relatório indica que, naquele momento, os médicos Belisário Penna e Arthur Neiva viam como característica de toda a população com que entraram em contato o abandono, o tradicionalismo, a total ausência de identidade nacional. Acreditamos que a imagem do Brasil doente foi pouco a pouco construída à medida da repercussão do próprio relatório de viagem e das publicações que lhe seguiram.

Os autores ressaltam o contraste entre o "desertão" do interior do País e a "Canaan Sertaneja" da retórica romântica, descrevendo o povo como ignorante, isolado, pobre em folclore, primitivo nos instrumentos de trabalho e nas trocas econômicas (praticamente não utilizavam moeda) e refratário ao progresso. Os habitantes das vilas e povoados desconheciam, em grande parte, o fósforo, o moinho de café e a máquina de costura. Esse quadro de isolamento era responsável pela ausência de qualquer sentimento de identidade nacional, tal como se evidencia no seguinte trecho: "raro o indivíduo que sabe o que é o Brasil. Piauí é uma terra, Ceará outra terra. Pernambuco outra (...) A única bandeira que conhecem é a do divino"' (Penna \& Neiva, 1916:121).

A ausência absoluta de sentimento nacional cra acentuada, de acordo com Penna e Neiva, pelo abandono do governo federal, cuja presença só se fazia sentir nos aspectos coercitivos. Mais uma vez, o texto do relatório é eloqüente:

Vivem eles abandonados de toda e qualquer assistência, sem estrada, sem polícia, sem escolas, sem cuidados médicos nem higiênicos (...) sem proteção de espécie alguma, sabendo de governos porque se lhes cobram impostos de bezerros, de bois, de cavalos e burros. (Penna \& Neiva, 1916:199)

A imagem do povo, em várias passagens, assemelha-se ao retrato do Jeca Tatu esboçado por Lobato. Muda, no entanto, a atribuição de responsabilidade pela apatia e pelo atraso. O governo, que abandona a população à sua própria sorte, e a incapacidade física e intelectual decorrente da doença, especialmente no caso das regiões em que se disseminava a doença de Chagas, são apontados como os verdadeiros responsáveis pela situação do interior do País. De qualquer forma, o povo brasileiro representava ainda uma miragem, um povo que estava por vir.

Distanciando-se da análise mais matizada e complexa do relatório da expedição científica, Belisário Penna nos oferece, em Saneamento do Brasil, uma versão mais precisa, até mesmo caricata, das relações entre a doença e a sociedade brasileira e a proposição mais radical em relação ao papel do governo federal no saneamento, povoamento e saúde pública. As idéias e a campanha de Penna influenciaram outros escritores como 
Monteiro Lobato que, em uma série de artigos publicados no jornal O Estado de São Paulo, esboçou uma nova imagem do Jeca Tatu: este estava indolente, por causa das doenças, uma vez tratado se tornaria a redenção do homem do interior e do próprio País. ${ }^{11}$

No texto de Belisário Penna, o Brasil é apresentado como um país de doentes e analfabetos, vítimas de uma indolência mórbida. O povo é novamente retratado como um ator em "estado de latência", que se manteria "bestializado" como no momento da Proclamação da República (Carvalho, 1987). Segundo o autor, " a bestialização permaneceu, agravada dia a dia pela miséria, pela doença generalizada e pelo alcoolismo incontrolável do povo ignorante" (Penna, 1923:99).

Ao discutir as causas para os fatos apontados, Penna considera determinantes de natureza social e política: a abolição abrupta do trabalho escravo, a extensão relativamente rápida das redes ferroviárias e a ausência de incentivo à atividade rural. Dos treze artigos publicados originalmente na imprensa, dez tratam, ao lado do tema das condições sanitárias, da responsabilidade política do regime republicano, ao menos do seu formato federalista, pela gravidade da situação nacional.

Penna afirmava que o País estaria dividido em "pequenas satrapias", entregues a tiranetes locais. Com a República, o Brasil promulgara em 1891 uma "constituição licenciosa" (Penna, 1923:157) na qual se consagrava a perda das principais virtudes do Império: a unidade de comando e a solidariedade nacional (Penna, 1923:158). A própria libertação dos escravos é vista como mal conduzida por ter lançado abruptamente enormes contingentes populacionais, desprotegidos e não qualificados, nas periferias das cidades, gerando o despovoamento do interior e a carência de mão-de-obra na lavoura. Ao mesmo tempo criava sérios problemas habitacionais, de educação e de saneamento nos centros urbanos.

Na tradição de Alberto Torres, Penna investe também contra a indústria e o urbanismo como prioridades nacionais, chamando atenção para o descaso com a agricultura e a indústria "natural" e para com as "classes agrícolas", os verdadeiros "alicerces da nacionalidade"' (Penna, 1923:149). Por último, completando a crítica, teríamos o equívoco das políticas de estradas que estimulariam as migrações para os centros urbanos e, na direção inversa, povoariam os sertões com as "pragas da cidade": o jogo, a sífilis, o álcool e o "gosto do luxo e da aventura".

Essa moldura mais geral do argumento permite compreender o lugar atribuído à doença na. sociedade brasileira. Ela seria resultado do abandono, da inoperância e da descentralização das políticas existentes e, ao mesmo tempo, fator de integração nacional, na medida em que passava a definir o próprio país. Portanto, para os missionários do saneamento, qualquer solução exigia a conscientização das elites brasileiras sobre os riscos e custos crescentes da manutenção desse quadro negativo e a necessidade de centralizar as ações de saúde.

As endemias rurais seriam o foco principal dessa ação, em especial a opilação (ancilostomose), o impaludismo (malária) e o mal de Chagas (tripanossomíase americana). A ancilostomose, a chamada "doença da preguiça", que, segundo Belisário Penna, infestava $70 \%$ da população rural, deveria ser o primeiro alvo de uma campa-

11 Esses artigos foram reunidos no livro Problema Vital, publicado originalmente em 1918. O texto a que fazemos referência neste trabalho é o da $11^{\underline{a}}$ edição, publicada em 1957. 
nha nacional de saneamento e educação higiênica. ${ }^{12} \mathrm{O}$ autor calculava que 6 milhões de brasileiros, quando comparados a trabalhadores estrangeiros, produziam apenas $1 / 3$ do que, livres das doenças, seriam capazes. O País despovoado, doente e improdutivo consistia também num obstáculo para qualquer política de imigração. Num comentário instigante, Penna sugere que o imigrante seria "abrasileirado" logo ao chegar ao País e ser marcado "com o ferrete da verminose" (Penna, 1923:55). Nesta interpretação, o imigrante se naturaliza por passar a compartilhar com o povo brasileiro aquilo que mais o identificava e distinguia: a doença.

Os elementos centrais desse discurso foram reproduzidos em vários outros textos, de Belisário Penna e de outros autores, especialmente nos editoriais e artigos publicados no periódico oficial da campanha do saneamento - a revista Saúde. Completando o diagnóstico dos "males do Brasil", em alguns editoriais se acentuou a idéia da ameaça à soberania nacional implicada no despovoamento e na presença de um "rebanho" doente em lugar de povo (Editorial, Saúde, n.3, 1918). Encontramos também nessa revista um artigo que pode ser considerado paradigmático do projeto de integração dos "sertões" proposto pelo movimento. Trata-se de $A$ Canaan Sertaneja, um entusiástico elogio à empresa agroindustrial criada por Delmiro Gouveia no sertão de Alagoas (Cavalcanti, 1918).

O autor relata a visita feita à propriedade chamando atenção para a instalação de água, luz e esgotos, e para as máquinas modernas da fábrica de linhas, a utilização do potencial hidrelétrico da Cachoeira de Paulo Afonso e a construção da vila operária. A obra, segundo ele, só fôra possível pela confluência das qualidades do sertanejo com a missão civilizadora do homem do litoral, papel que, aliás, era recorrentemente atribuído pelos participantes da campanha do saneamento aos cientistas e às expedições científicas (Britto \& Lima, 1991:28).

O projeto de integração do interior brasileiro e de construção da nacionalidade em novas bases encontrou a imagem mais expressiva na revisão feita por Monteiro Lobato de seu personagem Jeca Tatu, antes condenado por sua insuperável preguiça. Ao passar a acreditar na ciência médica e a seguir suas prescrições, o Jeca transforma-se. Livre da opilação e, como conseqüência, do estado permanente de desânimo, torna-se produtivo e, em pouco tempo, um próspero fazendeiro. Monteiro Lobato relata a ressurreição de Jeca Tatu na forma de uma parábola dirigida às crianças. O antigo caipira passou a competir com seu vizinho italiano e rapidamente o ultrapassou. Mais do que isso: o Jeca modernizou sua propriedade, introduziu novas lavouras e tecnologia e aprendeu a falar inglês. Ao fim da história, um ensinamento moral: Jeca Tatu transformara-se não apenas num homem rico, mas num incansável educador sanitário que transmitia a seus empregados todos os conhecimentos que aprendera. Morreu muito idoso, sem glórias, mas consciente de que havia cumprido sua missão (Lobato, 1957b).

Muitos elementos poderiam ser destacados da narrativa de Lobato, entre eles a comparação da produtividade do trabalhador nacional sadio com a do imigrante italiano;

12 A ancilostomose foi também objeto de ampla campanha sanitária promovida em escala mundial pela Fundação Rockefeller. Os registros sobre a atuação desse organismo em Porto Rico, e no sul dos Estados Unidos, entre as populações rurais, revela uma representação do povo muito próxima a que encontramos no Brasil, sendo freqüente a associação entre verminose e improdutividade. A Fundação Rockefeller teve também participação expressiva nas campanhas de combate à ancilostomose realizadas no Brasil. Sobre a associação entre opilação e identidade nacional nos Estados Unidos, vide Marcus (1989). 
a defesa enfática da modernização da agricultura como alternativa para o País; o fazendeiro norte-americano como modelo e a atribuição de uma responsabilidade social ao novo empresário rural. ${ }^{13}$ É significativo que a narrativa da ressurreição do Jeca reforce a superação de sua mentalidade tradicional. A ele, após a cura, não interessava mais trabalhar apenas para viver, como também não se desejava enriquecer apenas para ostentar consumo. A higiene seria o evangelho que daria sentido à missão deste brasileiro regenerado na terra. ${ }^{14}$

Cabe ressaltar que Lobato enfatiza mais a periferia dos núcleos urbanos do que os sertões como alvo prioritário de uma campanha de saneamento (Lobato, 1957b:313314). Isto sugere que o movimento tinha um diagnóstico comum sobre os males do Brasil e portava diferentes geografias para seus diferentes projetos de regeneração do País e do seu povo. De um lado, com a celebração de Delmiro Gouveia, um projeto de agroindústria no sertão nordestino em contraponto ao engenho tradicional e, de outro, com o Jeca Tatu renovado, o espírito do capitalismo agrário americano para, a partir de São Paulo, remover as estruturas tradicionais e improdutivas. Os dois projetos ressaltavam que o trabalhador brasileiro, sertanejo ou caipira, poderia ser recuperado se fosse retirado do abandono em que se encontrava e curado das doenças que o parasitavam.

Concluindo: na visão do movimento pelo saneamento do País, simbolizada nessa parábola de Monteiro Lobato sobre a ressurreição do homem brasileiro, a higiene seria o instrumento central para a reforma do País porque viabilizava a remoção do atributo que o identificava e o desqualificava: a doença.

\section{AS REPERCUSSÕES E IMPACTOS DA CAMPANHA PELO SANEAMENTO DO BRASIL}

A campanha pelo saneamento do Brasil, iniciada de forma não organizada em 1916 e ampliada a partir de 1918 com a criação da Liga Pró-Saneamento do Brasil, teve impactos significativos na sociedade brasileira. Desde a publicação do relatório de Penna e Neiva e da já citada frase de Miguel Pereira, o tema do saneamento e da saúde pública ganhou as páginas dos jornais e a tribuna do Congresso Nacional. Os próprios livros de Lobato e Penna resultaram de artigos publicados em jornais nos anos de 1916 e 1918 . A saúde se tornara uma questão central no debate político nacional, em grande parte moldado a partir dos argumentos dos militantes desse movimento.

Os jornais cariocas como O Paiz e o Correio da Manhã deram grande cobertura ao movimento e tornaram-se fóruns do debate sobre o saneamento rural. Uma leitura desses jornais relativa aos anos de 1918 e 1919 revela a presença diária do tema tanto em noticiários quanto em colunas e artigos de membros da Liga Pró-Saneamento e de outros autores: médicos, juristas, políticos etc. Temas como a profilaxia rural, a mortalidade infantil, as endemias, as soluções institucionais para a redenção do País, aparecem fre-

13 Para uma análise da "ressurreição do Jeca" com ênfase na questão da propriedade rural, vide Ribeiro (1993).

14 Cabe ressaltar que alguns trabalhos chamam a atenção para as estreitas relações entre higienismo e religião no início do movimento sanitarista norte-americano. Vide Rosenberg \& Smith-Rosenberg (1968) e Whorton (1982). 
qüentemente na imprensa, além da repercussão do debate legislativo em torno da proposta de criação de um Ministério da Saúde Pública, centralizando parte considerável dos serviços sanitários na esfera federal (Britto \& Lima, 1991). A imprensa evidenciava e, literalmente, reconhecia a penetração da campanha pelo saneamento nas várias esferas da vida pública como nesta passagem:

... o patriótico brado de alarma lançado por Miguel Pereira, Arthur Neiva, Belisário Penna, com o sentimento de responsabilidade que a investidura médica impõe na defesa da saúde pública, produziu o seu efeito salutar. No congresso fala-se em questões sanitárias. A imprensa tem mantido o assunto em foco e a opinião pública já vai sendo infiltrada pela idéia lançada, há dois anos, pelos iniciadores dessa campanha benemérita. (O Paiz, 28/07/1918)

Acompanhando as atividades do movimento pelo saneamento do Brasil, e revelando a difusão da preocupação com o tema da saúde pública, ocorreram manifestações das instituições médicas, especialmente aquela que veicula as opiniões das elites médicas: a Academia Nacional de Medicina (ANM). Ainda em 1917, uma comissão de notáveis, nomeada pela ANM, apresentou um relatório com sugestões para a promoção do saneamento dos sertões. ${ }^{15}$

A principal conclusão da comissão foi que para sanear o interior, considerando o caráter técnico do empreendimento, a complexidade do País, a disseminação das endemias e o nível de infestação da população, era necessário conceder autonomia aos serviços de saúde pública. Aconselhava a criação do Ministério da Saúde Pública, "constituído pela fusão dos vários serviços de higiene e assistência pública, dotado de um regulamento que o fortaleça na sua missão e entregue a um profissional de indiscutível competência'. ${ }^{16}$ O Ministério era apresentado como solução, mas sabendo das dificuldades a comissão sugeriu como recurso provisório a criação de um Conselho de Higiene, com atribuições de coordenar as ações de saúde e saneamento, desde que garantida a sua autonomia política, técnica, financeira e administrativa.

Segundo alguns, o Governo Wenceslau Brás teria acatado duas sugestões da comissão: a criação do Serviço de Quinina Oficial, para produzir medicamento de combate à malária, e de um serviço de profilaxia rural, autônomo em relação à Diretoria Geral de Saúde Pública, a partir da experiência dos postos sanitários na periferia do DF. ${ }^{17}$ Estes serviços foram a base para as primeiras mudanças significativas no papel da União.

Em setembro de 1918, discutindo as repercussões da campanha da Liga, o deputado pelo Rio de Janeiro, Azevedo Sodré, médico, membro e.ex-presidente da ANM, professor da Faculdade de Medicina do Rio de Janeiro, e membro da Liga, propõe a criação de um Ministério da Saúde Pública como mecanismo institucional para realizar as de-

15 A Comissão era composta por Miguel Couto, Miguel Pereira, Carlos Seidl, Afrânio Peixoto, Carlos Chagas e Aloysio de Castro. Este último substituíra Oswaldo Cruz, que falecera em fevereiro de 1917.

16 Relatório da Comissão está publicado nos Anais da Câmara Federal na sessão de 10/09/1917.

17 Para Miguel Couto, membro desta comissão e Presidente da ANM, o governo acatava suas sugestões, enquanto para Belisário Penna o Serviço de Profilaxia Rural resultava da reivindicação da Liga Pró-Saneamento. Essas interpretações eram fundamentalmente políticas uma vez que as propostas eram muito gerais e indistintas. O que importa é que as mudanças decorrem desse movimento mais geral de opinião pública que demandava reformas. 
mandas pelo saneamento do Brasil. Para Sodré, o saneamento não poderia ter caráter local, deveria ser uma obra nacional, e os estados da União não estavam preparados para isso, à exceção do Estado de São Paulo. ${ }^{18}$ Sua crítica voltava-se para a dispersão dos órgãos de saúde e saneamento em vários ministérios e, principalmente, para a subordinação da saúde, via DGSP ao Ministério da Justiça e Negócios Interiores, considerado essencialmente político pelo movimento.

O projeto de Sodré era moderado no que dizia respeito ao incremento do papel da União no campo do saneamento e saúde e condicionava a ação do novo Ministério a acordos e autorizações dos governos estaduais. Mesmo assim, o projeto sofreu duras críticas de outros parlamentares, em especial de Teixeira Brandão, presidente da Comissão de Saúde Pública da Câmara, médico, professor e membro da ANM. As críticas dirigidas a Sodré eram extensivas às reivindicações da Liga Pró-Saneamento. O argumento utilizado para derrotar o projeto de Sodré foi a sua inconstitucionalidade, uma vez que a reorganização da saúde pública federal proposta feria a autonomia dos estados e municípios garantida pela Carta de 1891, além de representar um aumento de despesas e de burocracia.

Os argumentos favoráveis e contrários ao ministério são reproduzidos pela imprensa e provocam debates acalorados. Apesar de a saúde e o saneamento terem se tornado problemas nacionais, e o projeto ter sido bastante debatido, não houve maioria legislativa em torno de mudanças na direção desejada pela Liga Pró-Saneamento. O projeto recebeu pareceres contrários em várias comissões e teve como maiores opositores os membros da Comissão de Saúde Pública da Câmara Federal.

Um fato pontual e decisivo para a campanha e as demandas do movimento pelo saneamento foi o fato de o Brasil, desde o final de 1918, especialmente nas grandes cidades, ter sido atingido pela epidemia de gripe espanhola. A capital do País, entre outubro e dezembro, desorganizou-se completamente. Além do grande número de mortes, a epidemia paralisou a vida da cidade, com falta de alimentos e remédios, carestia, e a completa incapacidade das autoridades públicas em responder adequadamente. As descrições dos jornais, que foram submetidos à censura, são aterrorizantes. Faltavam coveiros e caixões para tantos mortos. Essa experiência de terror e medo causada por uma epidemia que atingiu as cidades sem muita distinção de classe social, ocupação ou região, com a autoridade pública revelando-se impotente e despreparada, significou uma inflexão nas respostas até então dadas pelo Estado. No Distrito Federal calcula-se que metade da população tenha contraído a gripe, com aproximadamente 12 mil mortos entre outubro e dezembro de 1918 (Torres, 1919; Bertolli Filho, 1989; Lima \& Britto, 1991).

A epidemia oferecia à opinião pública razões suficientes para desconfiar da estrutura federal vigente na área de saúde. Para os defensores da centralização, as estruturas públicas existentes não seriam mais capazes de resolver problemas elementares de saúde pública, portanto tornava-se necessária uma revisão completa da competência da União nesta área. $\mathrm{O}$ elemento catalisador dessas mudanças foi uma epidemia urbana que, ao explicitar os efeitos negativos da crescente interdependência social, promoveu uma consciência sobre a necessidade de soluções amplas e de largo alcance. A Câmara dos 
Deputados que, em 1918, através da sua Comissão de Saúde Pública, vetara o projeto de criação do Ministério da Saúde do deputado Azevedo Sodré, um ano depois, no final de dezembro, aprovava um substitutivo a uma mensagem do Presidente Epitácio Pessoa criando o Departamento Nacional de Saúde Pública (DNSP) com atribuições e mecanismos de financiamento federal amplos, ainda que mantivesse a necessidade de acordo com os estados para obras de saneamento e profilaxia (Labra, 1985; Castro Santos, 1987; Hochman, 1991). Antes disso, em abril de 1919, a reestruturação do Serviço de Profilaxia Rural, vinculado não mais a DGSP mas diretamente ao Ministério da Justiça, significou um avanço considerável no papel do poder central nos campos da saúde pública e do
saneamento rural.

Epitácio Pessoa, recém-empossado, sugeria a criação de um Ministério da Saúde e Instrução Pública. Mas, sabedor das dificuldades que enfrentaria, aceitava uma reforma que ampliasse os serviços sanitários federais. ${ }^{19}$ Argumentava que a medida não implicaria sobrecarga no orçamento da União, já que os serviços dispersos em vários ministérios seriam reunidos no novo órgão, além de ser criado um Fundo Sanitário. Influenciado pela campanha do saneamento, Pessoa defendia alguma forma de centralização dos serviços sanitários.

Depois de intensos debates e muitos substitutivos, foi aprovado na Câmara, e no Senado, um substitutivo de Teixeira Brandão, justamente aquele que no ano anterior fôra o maior adversário da idéia de centralização. Em fins de dezembro de 1919, foi criado o DNSP, reorganizando e dando maior amplitude aos serviços sanitários federais, mantendo a necessidade de acordos com os estados para que os trabalhos de profilaxia rural fossem realizados pela União. A aprovação do novo Departamento, depois de tantas resistências, pode ser explicada pela formação de uma consciência sobre o estado sanitário do país via campanha da Liga Pró-Saneamento, pelo impacto da epidemia de gripe espanhola, pelo empenho do presidente da república e pela percepção das elites políticas estaduais de que, sem o consórcio do governo federal, apenas São Paulo poderia implementar, e efetivamente o fazia, políticas de saúde e saneamento (Castro Santos, 1987,
1993; Hochman, 1993).

Belisário Penna afirmava no último número da revista Saúde (dezembro, 1919) que o novo Departamento era a realização dos objetivos da Liga Pró-Saneamento. Na segunda edição de Saneamento no Brasil ele revelaria que a Liga fora extinta porque não teria mais razão para existir (Penna, 1923). A partir daquele momento era realizar o ideal do saneamento, gerindo a nova organização. O ano de 1920 marcou o início da nacionalização das políticas de saúde e saneamento e da definição de uma nova identidade profissional para um grupo de médicos, a de profissionais de saúde pública vinculados à administração pública. E foram membros da Liga Pró-Saneamento do Brasil que dirigiram esses novos serviços, como Carlos Chagas, diretor do DNSP de 1920 a 1926 e Belisário Penna, na Diretoria de Saneamento e de Profilaxia Rural de 1920 a 1923. 


\section{CONSIDERAÇÕES FINAIS}

Procuramos neste trabalho reconstruir e analisar o processo de elaboração da metáfora da doença como expressão do Brasil e dos brasileiros. O Brasil doente descoberto pelos médicos e higienistas se contrapunha tanto às visões negativas e desesperançadas do País como àquelas de caráter ufanista. O que distinguia os sertões brasileiros e seus habitantes era o fato de terem sido abandonados pela "República dos Bacharéis" e encontrarem-se doentes. Esse pedaço de Brasil abandonado não era nem tão longínquo nem tão pequeno assim. Afinal, como lembrava o médico e escritor Afrânio Peixoto, os sertões do Brasil começavam quando terminava a Avenida Central, portanto na periferia da cidade do Rio de Janeiro, capital da República.

O diagnóstico médico sobre o Brasil e as soluções apontadas tiveram conseqüências que ultrapassaram o curto período histórico aqui analisado. O movimento pela reforma da saúde pode ter seus impactos avaliados na reorganização dos serviços sanitários federais que se ampliaram e se racionalizaram consideravelmente ao longo dos anos de 1920, deixando um legado institucional que foi pouco alterado nas duas décadas seguintes. Além disso, este movimento reivindicou para os médicos um papel relevante na gestão da saúde pública.

Nesse processo, formou-se uma nova identidade profissional, a de médicos especializados em saúde pública, empregados do governo, com cursos de especialização e organização profissional distinta dos demais médicos (Labra, 1985). Assim, o movimento pelo saneamento do Brasil teve conseqüências de longo prazo em termos de políticas públicas e identidades profissionais, e seus diagnósticos e argumentos ajudaram a legitimar a presença do Estado no campo da saúde pública. E, o mais significativo, a descoberta da importância sociológica da doença, foi incorporada por parte considerável daqueles que refletiram sobre o Brasil e sobre a identidade de ser brasileiro. A identificação da doença como o principal problema do País não o condenava à barbárie eterna mas, ao contrário, apontava os instrumentos para sua superação: a ciência médica e as políticas públicas de saúde e saneamento. Assim, a sensação de alívio experimentada por Monteiro Lobato pôde ser compartilhada por várias gerações de intelectuais.

Para finalizar, lembremos que em Casa-Grande \& Senzala (1933), uma das principais obras de interpretação do Brasil, Gilberto Freyre abordou com rara sensibilidade a metáfora da doença como expressão do País e de seu povo:

... vi uma vez, depois de quase três anos de ausência de Brasil, um bando de marinheiros nacionais-mulatos e cafuzos - descendo não me lembro se do São Paulo ou do Minas pela neve mole do Brooklin. Deram-me a impressão de caricaturas de homens e veio-me à lembrança a frase de um viajante inglês ou americano que acabara de ler sobre o Brasil: "the fearfully mongrel aspect of population". A miscigenação resultava naquilo. Faltou-me quem me dissesse, então, como em 1929, Roquete Pinto aos arianistas do Congresso Brasileiro de Eugenia, que não eram simplesmente mulatos ou cafuzos os individuos que eu julgava representarem o Brasil, mas mulatos ou cafuzos doentes. (Freyre, 1978:23) 


\section{REFERÊNCIAS BIBLIOGRÁFICAS}

ALBUQUERQUE, M.; ALVES, F. A. P.; BENCHIMOL, J. L.; SANTOS, R. A. S.; THIELEN, E. U. \& WELTMAN, W., 1992. A Ciência a Caminho da Roça. Imagens das Expedições Científicas do Instituto Oswaldo Cruz (1903-1911). Rio de Janeiro: Casa de Oswaldo Cruz, Fiocruz.

BENCHIMOL, J., 1990. Manguinhos: do Sonho à Vida - A Ciência na Belle Époque. Rio de Janeiro: Casa de Oswaldo Cruz, Fiocruz.

BENCHIMOL, J. \& TEIXEIRA, L. A., 1993. Cobras, Lagartos e outros Bichos. Uma História Comparada dos Institutos Oswaldo Cruz e Butantã. Rio de Janeiro: Editora UFRJ/Casa de Oswaldo Cruz, Fiocruz.

BERTOLLI FILHO, C., 1989. A gripe espanhola em São Paulo. Ciência Hoje, 10:31-41.

BOMFIM, M., (1905) 1993. América Latina. Seus Males de Origem. Rio de Janeiro: Topbooks.

BRITTO, N., 1995. Oswaldo Cruz: A Construção de um Mito da Ciência Brasileira. Rio de Janeiro: Editora Fiocruz.

BRITTO, N. \& LIMA, N. T., 1991. Saúde e nação. A proposta do saneamento rural. Um estudo da revista saúde. Estudos de História e Saúde, 3.

CAMPOS, A. L. V., 1986. A República do Picapau Amarelo. São Paulo: Martins Fontes.

CARVALHO, J. M., 1987. Os Bestializados. O Rio de Janeiro e a República Que Não Foi. São Paulo, Companhia das Letras.

CARVALHO, J. M., 1994. Brasil, naciones imaginadas. In: De Los Impérios a las Naciones: IberoAmerica. (A. Aninno, L. C. Leiva \& F. Guerra, orgs.), pp. 401-423, Saragoza: Ibercaja.

CASTRO SANTOS, L. A., 1985. O pensamento sanitarista na primeira república: uma ideologia de construção da nacionalidade. Dados-Revista de Ciências Sociais, 28:193-210.

CASTRO SANTOS, L. A., 1987. Power, Ideology and Public Health in Brazil (1889-1930). Ph.D. Thesis, Cambridge: Harvard University.

CASTRO SANTOS, L. A., 1993. A reforma sanitária "pelo alto": o pioneirismo paulista no início do século XX. Dados-Revista de Ciências Sociais, 36:393-418.

CAVALCANTI, P., 1918. A Canaan sertaneja. Saúde, 4-6:265-321.

CHAGAS FILHO, C., 1993. Meu Pai. Rio de Janeiro: Casa de Oswaldo Cruz, Fiocruz.

COSTA, N. R., 1985. Lutas Urbanas e Controle Sanitário: Origens das Políticas de Saúde no Brasil. Petrópolis: Vozes/ Rio de Janeiro: Abrasco.

COUTINHO, A., 1978. Introdução à Literatura Brasileira. Rio de Janeiro: Civilização Brasileira.

CUNHA, E., (1902) 1963. Os Sertões: Campanha de Canudos. Brasília: Editora da UnB.

FREYRE, G., (1933) 1978. Casa Grande e Senzala. Formação da Família Brasileira sobo Regime Patriarcal. Rio de Janeiro: Livraria José Olympio Editora.

HOBSBAWN, E., 1991. Nações e Nacionalismo. Rio de Janeiro: Paz e Terra. 
HOCHMAN, G., 1991. Veto e Negociação: A Centralização da Política de Saúde em Debate na Câmara de Deputados (1918-1919). Rio de Janeiro: Casa de Oswaldo Cruz, Fiocruz. (mimeo.)

HOCHMAN, G., 1993. Regulando os efeitos da interdependência: sobre as relações entre saúde pública e a construção do Estado (Brasil 1910-1930). Estudos Históricos, 11:40-61.

JOLL, J., 1982. A Europa desde 1870. Lisboa: Editora Dom Quixote.

LABRA, M. E., 1985. O Movimento Sanitarista nos Anos 20: Da Conexão Internacional à Especificidade da Saúde Pública no Brasil. Tese de Mestrado, Rio de Janeiro: Ebap/FGV.

LIMA, N. T. \& BRITTO, N., 1991. A Campanha do Saneamento Rural na Imprensa do Rio de Janeiro (1918-1919). Rio de Janeiro: Casa de Oswaldo Cruz, Fiocruz. (mimeo.)

LOBATO, J. B. M., (1914) 1957a. Urupês. São Paulo: Brasiliense.

LOBATO, J. B. M., (1918) 1957b. Mr. Slang e o Brasil e Problema Vital. São Paulo: Brasiliense.

LUZ, M. T., 1982. Medicina e Ordem Politica Brasileira: Politicas e Instituições de Saúde (1850-1930). Rio de Janeiro: Graal.

MARCUS, A. I., 1989. Physicians open a can of worms. American nationality and hookworm in the United States, 1893-1909. American Studies, 30:103-119.

OLIVEIRA, L. L., 1990. A Questão Nacional na Primeira República. São Paulo: Brasiliense/CNPq.

PENNA, B. \& NEIVA, A., 1916. Viagem científica pelo norte da Bahia, sudoeste de Pernambuco, sul do Piauí e de norte a sul de Goiás. Memórias do Instituto Oswaldo Cruz, 8:74224.

PENNA, B., 1923. O Saneamento do Brasil. Rio de Janeiro: Editora dos Tribunais.

PORTER, D., 1991. 'Enemies of the race': biologism, environmentalism, and public health in Edwardian England. Victorian Studies, 34:159-178.

RIBEIRO, M. A. R., 1993. História Sem Fim... Inventário da Saúde Pública, São Paulo1880-1930. São Paulo: Editora Unesp.

ROSENBERG, C. E. \& SMITH-ROSENBERG, C., 1968. Pietism and the origins of the American public health movement: A note on John H. Griscom and Robert M. Hartley. Journal of the History of Medicine and Allied Sciences, 23:16-35.

SCHWARTZMAN, S., 1979. Formação da Comunidade Científica no Brasil. São Paulo: Companhia Editora Nacional.

SKIDMORE, T., 1976. Preto no Branco: Raça e Nacionalidade no Pensamento Brasileiro. Rio de Janeiro: Paz e Terra.

STEPAN, N., 1976. Gênese e Evolução da Ciência no Brasil. Rio de Janeiro: Artenova e Fundação Oswaldo Cruz.

STEPAN, N., 1991. The Hour of Eugenics: Race, Gender and Nation in Latin America. New York: Cornell University Press.

TORRES, A., 1914a. O Problema Nacional Brasileiro. Rio de Janeiro: Imprensa Nacional. 
TORRES, A., 1914b. A Organização Nacional. Rio de Janeiro: Imprensa Nacional.

TORRES, T., 1919. A Saúde Pública em 1918. Revista Médico-Cirúrgica do Brazil, ano XXVII, 2:29-54.

WHORTON, J., 1982. Crusaders for Fitness - The History of American Reformers. Princeton: Princeton University Press.

\section{OUTRAS FONTES}

Jornais e Revistas:

O Paiz (1918/1919)

Correio da Manhã (1918/1919)

Saúde. Revista de Higiene e Assuntos Sociais (publicada em 1918 e 1919)

Outros:

Anais da Câmara Federal, 1917-1919 


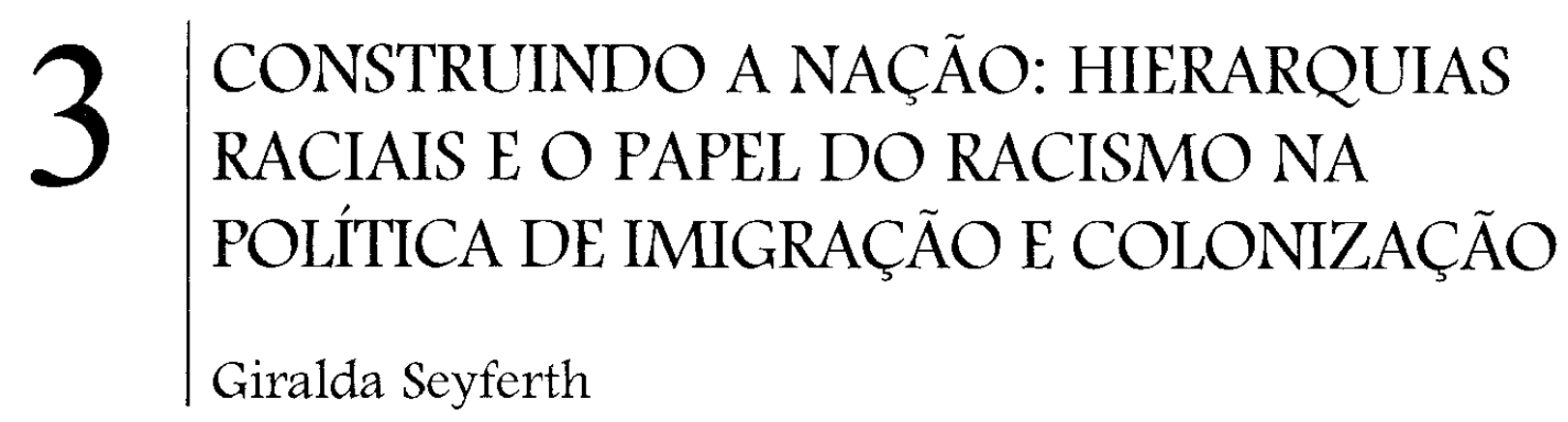

\section{INTRODUÇÃO}

Num texto escrito provavelmente ao término da Primeira Guerra Mundial - que designou como "guerra de nacionalidades"- Marcel Mauss fez um estudo da nação no campo político (onde o Estado nacional aparece como fenômeno europeu ocidental) e, ao mesmo tempo, apresenta o nacionalismo como algo negativo. Nos seus termos, "para um grande número de nossos contemporâneos, a noção de nação é, antes de tudo, aquela de nacionalidade, aquela de nacionalismo" (Mauss, 1969:576). Entre as características normalmente associadas à nação, Mauss inclui a crença na raça, língua e civilização comuns - que embasa a maior parte das ideologias nacionalistas. Assim, em tom irônico, diz que "a raça cria a nacionalidade num grande número de espíritos ...e porque a nação criou a raça acreditamos que a raça criou a nação" (Mauss, 1969:595-596). Da mesma forma, tece comentários sobre o "conservantismo", o "proselitismo" e o "fanatismo" lingüístico que exprimem a profunda individualização das modernas línguas nacionais; a noção de "língua materna" desvirtuando o verdadeiro sentido da nação, tanto quanto a noção de raça, a ponto de serem criadas "línguas nacionais" pelas nacionalidades que não as possuem. Critica, ainda, o que chama "nacionalização do pensamento", "folclorização", a partir da "trágica noção de civilização dominante" porque "uma nação acredita na sua civilização, nos seus costumes... tem o fetichismo da sua literatura, da sua plástica, da sua ciência, da sua técnica, da sua moral, da sua tradição e do seu caráter" (Mauss, 1969:599).

Mauss certamente está se reportando aos excessos do nacionalismo, onde os valores nacionais são exagerados em detrimento dos valores dos outros. De fato, em muitos casos, o conteúdo político do conceito de nação é suplantado pela idéia de nacionalismo, que atribui valor excessivo à individualidade nacional - a nacionalidade pensada como atributo natural. E tal individualidade é, em parte, construída sobre a idéia de raça, por um lado, e sobre a concepção de língua nacional e cultura (ou civilização) nacional, por outro lado - o que resulta na equação 1 povo (raça) +1 cultura (civilização) +1 língua $=1$ nação! A este esquema se acrescentou o Estado e este devia coincidir com a Nação, conforme pode ser verificado na maior parte das ideologias nacionalistas. Segundo Banton (1977:7), "os que pregaram o nacionalismo no século XIX estavam ansiosos por juntar em unidades políticas singulares os povos que eles pensavam ter uma origem comum. Os grupos intermediários e as minorias nacionais destruíram este esquema". 
Apesar dos nacionalismos, as minorias étnicas se multiplicavam e, na sociedade moderna, não tem como única perspectiva a assimilação, ou, nos termos brasileiros, o "caldeamento". O próprio Banton assinalou que as minorias étnicas são grupos que possuem atributos nacionais.

A semelhança entre as concepções de pertencimento étnico e nacional também foi assinalada por Max Weber (1971), preocupado com a ambigüidade das noções de etnia e nação e as dificuldades de concebê-las sociologicamente. Apesar de privilegiar o conteúdo político do conceito de nação, a análise de Weber se volta para as concepções de nacionalidade e sentimento nacional e, neste plano, os termos de definição são os mesmos empregados na análise das "comunidades étnicas"- habitus, vida em comum etc.

Gellner (1983) definiu nacionalismo como princípio político que afirma a coincidência entre unidade política e nacional. Na prática, esta coincidência é pouco freqüente porque fronteiras políticas e étnicas raramente são as mesmas.

De fato, a crença na origem comum e num processo histórico compartilhado que servem de fundamento à noção de pertencimento a um grupo étnico estão muito próximas aos ideais nacionalistas que dão sentido primordial à nacionalidade. As similaridades das concepções de comunidade nacional e comunidade étnica foram assinaladas por diferentes autores, inclusive Weber (1971), que trata de ambas num mesmo capítulo; e algumas análises mais recentes sobre nação e nacionalismo remetem explicitamente à questão da etnicidade - caso de Smith (1986) e Hobsbawn (1991), entre outros. As dificuldades conceituais são óbvias pois a nação é, na prática, confundida com nacionalismo (que vem antes do surgimento dos Estados nacionais, segundo Hobsbawn), e sua definição mudou bastante ao longo do século XIX.

Para os propósitos deste trabalho, interessa antes a idéia de nacionalismo, na forma definida por Boehm (1933) num verbete da Enciclopaedia of the Social Sciences: "em seu sentido amplo, se refere à atitude que atribui à individualidade nacional um lugar de destaque na hierarquia de valores". Esta definição certamente está relacionada ao formato assumido pelos nacionalismos nas últimas décadas do século XIX, nos quais "a etnicidade e a língua tornaram-se o critério central, crescentemente decisivo ou mesmo único para a existência de uma nação potencial", conforme observação de Hobsbawn (1991:126). O fenômeno destacado por este autor para a segunda metade do século XIX é o que chama de "nacionalismo étnico" que foi impulsionado não só pela intensificação de movimentos nacionalistas nos impérios multinacionais (sobretudo austríaco, russo e turco), mas também através dos movimentos imigratórios e da ciência que ajudou a transformar a raça em conceito central das ciências sociais.

A identificação das nações fundamentada na idéia de raça, assim, suplantou, ao final do século XIX, o nacionalismo cultural elaborado pelo romantismo, no qual a língua nacional era o elemento fundamental, juntamente com o folclore demarcador das "tradições populares". Muitos nacionalismos, então, descobriram o que Hannah Arendt (1976) chamou de "nova chave da história" - o racismo. Este termo designa as doutrinas que afirmaram a desigualdade das raças humanas partindo do pressuposto que a cultura é biologicamente determinada. A idéia de raça construída sobre hierarquias denotando desigualdade dominou o pensamento social em muitos lugares, inclusive no Brasil. Foi respaldada, em parte, pela ciência, principalmente pela Antropologia Física empenhada em classificar a humanidade em tipos naturais, arbitrando certas características fenotípicas por suas freqüências em diferentes grupos humanos; mas, igualmente, por alguns estu- 
diosos do campo das ciências sociais e humanas, que usaram e abusaram da metáfora darwinista da "sobrevivência dos mais aptos" e que inventaram a Eugenia para sugerir políticas públicas que, entre outras coisas, implicavam limpeza étnica.

$O$ respaldo científico dado às doutrinas raciais vigentes na passagem para o século XX remete à sua importância como ideologia para finns políticos. Neste caso, conforme Arendt (1976), os "pregadores científicos" são mais importantes que os cientistas - caso de autores como Gobineau, Chamberlain, Lapouge, Haeckel etc. - e dão elementos convincentes para a afirmação das individualidades nacionais. Para Arendt, a tragédia do Estado-nação estava justamente na "consciência nacional" que forçou o Estado a reconhecer como cidadãos somente os nacionais. Enfim, podemos voltar a Mauss (1969:595) que, entre outras coisas, afirma: "uma nação moderna acredita na sua raça".

Não cabe aqui discutir a gênese do conceito de raça no contexto das teorias que foram elaboradas principalmente na segunda metade do século XIX, e mais tarde rotuladas "racistas". Guardadas as diferenças de interpretação, todas elas tinham em comum o dogma de que a diversidade humana, anatômica e cultural, era produzida pela desigualdade das raças; e a partir deste dogma, produziram-se hierarquias raciais que invariavelmente localizavam os europeus civilizados no topo, os negros "bárbaros" e os índios "selvagens" se revezando na base, e todos os demais ocupando as posições intermediárias. Os exercícios tipológicos de classificação racial variavam conforme a seleção de características - cor da pele, capacidade craniana, índice cefálico etc. - e não se limitavam às quatro ou cinco grandes raças geográficas identificadas pelos cientistas desde fins do século XVIII. Nas hierarquias racistas nem todos os brancos eram considerados iguais e a própria posição de classe se tornou elemento denotativo de inferioridade, como na classificação de Lapouge que inferiorizou todos os braquicéfalos europeus por oposição aos seus superiores arianos dolicocéfalos.

O darwinismo social - principal doutrina racista vigente na passagem do século radicalizou o primado das leis biológicas na determinação da civilização, afirmando que o progresso humano é um resultado da luta e da competição entre raças, vencendo os mais capazes (ou aptos) - no caso, os brancos, porque as demais raças, principalmente os negros, acabariam sucumbindo à seleção natural e social. Apesar da condenação à mestiçagem entre raças desiguais, estes darwinistas sociais "pensavam que a operação da seleção natural criaria raças puras a partir da diversidade que então era dominante; e muitos deles mantiveram que, se adotassem medidas de eugenia, a mudança biológica poderia estar do lado do progresso humano" (Banton, 1977:89). Esta afirmação, aparentemente levada a sério como mecanismo geral de seleção por muitos brasileiros do período, se aplicava aos europeus. Nenhum racista como Lapouge defenderia a mistura com raças consideradas inferiores. No contexto das discussões sobre a mestiçagem, os racistas de fins do século XIX também resgataram o trabalho de Gobineau (1853), que atribuía a decadência das civilizações aos "excessos de mestiçagem".

A miscigenação se transformou em assunto privilegiado no discurso nacionalista brasileiro após 1850 - vista como mecanismo de formação da nação desde os tempos coloniais e base de uma futura raça histórica brasileira, de um tipo nacional, resultante de um processo seletivo direcionado para o branqueamento da população. Como conseqüência, será assunto obrigatório na discussão da política imigratória, especialmente a relacionada com a colonização, porque nesta estava em jogo o outro elemento fundamental para a nação - a ocupação do território. Esta discussão - que toma a idéia de raça 
e as classificações raciais como referência para o modelo de colonização baseado na pequena propriedade familiar - ć o objeto do presente trabalho, focalizando, sobretudo, as primeira décadas do período republicano, quando as ideologias racistas tiveram influência preponderante em segmentos da elite brasileira voltados para a análise da política
imigratória.

\section{F. COLONIZAÇÃO NO IMPÉRIO}

As primeiras tentativas de colonização com imigrantes europeus ocorreram antes da independência: houve assentamentos de alemães no Nordeste e de suíços no Estado do Rio de Janeiro em 1818, com a intenção de implementar um modelo de agricultura diverso da grande propriedade monocultora. Uma tentativa anterior de assentamentos de pequenos agricultores, com motivo semelhante mas procurando, sobretudo, uma solução para a ocupação territorial, especialmente no Sul, contou com colonos provenientes das Ilhas Açores, que se estabeleceram em terras litorâneas do Rio Grande do Sul e Santa Catarina (e, também, no extremo norte) na segunda metade do século XVIII. Os açorianos, porém, não foram em número suficiente para povoar os "vazios demográficos". Por outro lado, as experiências com alemães no Nordeste fracassaram e o empreendimento com imigrantes suíços em Nova Friburgo não atraiu um fluxo imigratório da Suíça para

Após a independência a colonização com imigrantes foi retomada em 1824, voltada para o Sul do País em parte devido ao fracasso da experiência com alemães no Nordeste, mas também por causa das disputas territoriais com a Argentina e o Uruguai. O Norte passou a ser visto como região problemática para estabelecer curopeus em face do clima tropical; mas, na verdade, ao longo do Império quase todas as discussões sobre colonização levantaram a questão da grande propriedade escravocrata como entrave para qualquer política consistente de imigração. A rigor, a primeira fase do sistema de colonização com imigrantes não produziu grandes resultados e foi interrompida, no Sul em 1830 e só retomada em 1846, após a revolução farroupilha. Entre 1818 e 1850 o Brasil recebeu um número relativamente pequeno de europeus (menos de 20.000 indivíduos) $^{l}$ e, entre eles, cerca de scis mil alemães foram encaminhados para projetos de colonização nos Estados do Rio Grande do Sul, Santa Catarina e Paraná. E quase dois mil suíços fundaram Nova Friburgo (Rio de Janeiro) em 1819; mas a imigração suíça começou e termi-
nou neste mesmo ano.

$O$ debate sobre a colonização tornou-se mais acirrado na década de 1840 , diante das dificuldades de atrair imigrantes da Europa. Uma política mais consistente passou a vigorar em 1850, com a promulgação da Lei 601 que regulamentou a concessão de terras públicas e tornou mais fácil a expedição de títulos de propriedade para estrangeiros - um ato coincidente com a abolição do tráfico de escravos. Durante o Império, os debates so-

Conforme dados de Carneiro (1950). Este total inclui pouco mais de duas centenas de portugueses, ou-

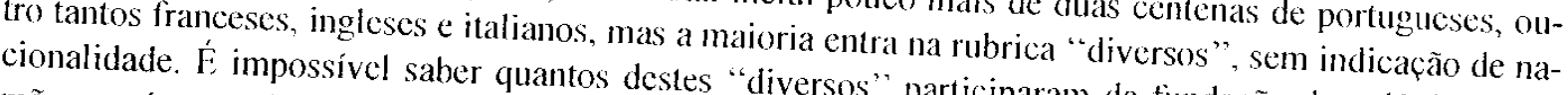
mães e suiços, assim, formaram os dois contines "diversos" participaram da fundação de colônias. Ale- 
bre política de imigração/colonização girou em torno de dois conjuntos de questões: a) as dificuldades decorrentes do assentamento de imigrantes em terras devolutas, isolados, e as medidas necessárias ao sucesso econômico das colônias - tendo como modelo padrão os assentamentos já realizados, fato que levou a uma hierarquização de imigrantes com base na sua suposta capacidade para produzir uma agricultura "moderna"; b) a abolição da escravidão como única medida capaz de tornar o Brasil um país civilizado com seu corolário, o "trabalho livre" associado ao imigrante europeu; na prática, isto excluiu os "nacionais" (trabalhadores livres e escravos) do sistema de colonização com pequena propriedade.

Os dois temas estão presentes num texto publicado em 1846 pelo Visconde de Abrantes, então em missão especial do governo brasileiro em Berlim, onde sugere um conjunto de medidas necessárias para atrair preferencialmente imigrantes de nacionalidade alemã. ${ }^{2}$ Para ele, os alemães, por sua índole e sua capacidade como agricultores e artífices, eram os mais recomendados para colonizar. Entre as medidas recomendadas lista: a abolição da escravidão (pelos entraves que o regime escravista impunha à propaganda na Europa), a simplificação da naturalização, um sistema de venda de terras públicas aos imigrantes, regulamentado depois pela Lei 601 , além de mudanças que atingiam o poder temporal da Igreja Católica (que estaria dificultando a vinda de imigrantes de religião protestante) etc. De forma mais elaborada, o que foi sugerido por Abrantes em 1846 será objeto de manifestações mais inflamadas nas décadas seguintes, como pode ser visto, por exemplo, em textos de A. C. Tavares Bastos, Augusto de Carvalho e J. C. de Menezes e Souza $^{3}$ - que representam a parcela da elite favorável à colonização com pequena propriedade, com uma postura crítica em relação ao sistema de parceria, posto em prática pelos grandes fazendeiros do café em São Paulo, a partir da experiência pioneira do Senador Vergueiro na década de 1850 que terminou com uma revolta de colonos em Ibiacaba em $1856 .^{4}$

Nas três obras citadas, a imigração (européia) é apresentada como instrumento da civilização; a escravidão e a grande propriedade como impedimento à imigração espontânea, estorvo ao desenvolvimento econômico e do trabalho livre. Pode haver alguma variação na forma como a questão da escravidão é abordada. Tavares Bastos, por exemplo, afirma que "a imigração não é incompatível com a escravidão", mas sim "incompatível com o tráfico de escravos", já abolido (Tavares Bastos, 1976). Os outros dois autores mencionados simplesmente consideram a abolição uma condição indispensável para acabar de vez com a imagem negativa do País na Europa. São detalhes que não afastam tais autores dos dois conjuntos de questões mencionados antes. Criticam a falta de vias de

2 O texto "Memória sobre os meios de promover a colonização" foi republicado na Revista de Imigração e Colonização, ano II. $\mathrm{n}^{\underline{o s}} .2 / 3,1941$.

3 A memória "Reflexões sobre a Imigração", de Tavares Bastos, foi apresentada à Sociedade Internacional de Imigração em 1867; o texto do jornalista de Campos (RI) Augusto de Carvalho data de 1874 e o do Conselheiro Menezes e Souza é um relatório apresentado ao Ministério da Agricultura. Comércio e Obras Públicas, publicado pela Tipogratia Nacional em 1875.

4 A revolta de colonos foi relatada por um dos seus lideres, Thomas Davatz, em livro publicado na Europa na mesma década (Davatz. 1941). A repercussão dos acontecimentos e outras denúncias sobre as más condições das colônias em geral teve como resultado prático um decreto prussiano que proibiu a imigração de alemães para o Brasil. 
comunicação que deixa as colônias fora do alcance dos mercados consumidores - já que o Estado privilegiou a ocupação de terras públịcas, consideradas desabitadas; ${ }^{5}$ as colônias foram estabelecidas em áreas de floresta, margeando os principais cursos d'água que serviram como via precária para o escoamento da produção. Falam da necessidade de taxar com rigor os grandes proprietários que possuem "vastas extensões das melhores terras" sem cultivá-las, enquanto a colonização se faz em terras nem sempre apropriadas para cultivo. Sugerem modificações nos contratos de parceria vigentes em São Paulo, de forma a torná-los mais atrativos para os europeus. Exigem, ainda, mudanças na lei de naturalização, liberdade religiosa, instituição do casamento civil, o fïm da "ambição de mando temporal do episcopado brasileiro"' (nos termos de Menezes e Souza, 1875:33).

Por outro lado, as construções em torno do "trabalho livre"(ou "braço livre") que remetem à abolição - deixam claro, conforme frase de Carvalho (1874:189), que "a colonização não deve ser apenas a substituição do odioso tráfico de africanos". Apesar da condenação explícita do escravismo, não há qualquer preocupação com o destino da população escrava, nem mesmo com os demais trabalhadores nacionais, e o significado mais imediato de "trabalho livre" é a desqualificação dos negros e mestiços para o trabalho independente. Eram, pois, considerados incapazes de agir por iniciativa própria pressupondo, portanto, que fracassariam como pequenos proprietários.

Desta forma, a política de colonização se voltou para a Europa em busca de colonos, usando, durante o Império, o expediente dos contratos firmados com aliciadores que se encarregavam da propaganda e do recrutamento em diversos países europeus. Nos autores citados há uma clara preferência pelos alemães - explicitamente manifestada ou indiretamente sugerida a partir das investidas contra a posição oficial da Igreja Católica e seu poder temporal. As dificuldades encontradas pelos agenciadores na Alemanha fez com que as atenções se voltassem para a Itália a partir da década de 1870 .

A ocupação do território e a introdução de agricultores modernos voltados para a produção de alimentos, num sistema que privilegiou a livre iniciativa, onde o modelo farmer americano era o objetivo a atingir, ${ }^{6}$ são os temas centrais neste debate, mas seus autores também se empenharam na elaboração de hierarquias raciais, descartando como "atraso" qualquer corrente imigratória africana ou asiática. A desqualificação dos não brancos se faz por critérios de natureza moral e pela suposta incapacidade de produzir num sistema de livre iniciativa. Ou, quando não há uma desqualificação explícita, o modo como o "trabalho livre" é discutido omite a questão posta pelo fím da escravidão: é como se os descendentes de africanos estivessem simplesmente destinados ao desaparecimento no contexto de uma civilização não escravista. Por outro lado, as considerações sobre uma possível imigração asiática, mais especificamente da China, são significativas das premissas de cunho racial presentes no debate. Menezes e Souza se mostra radicalmente contra essa possibilidade, temendo seus efeitos de "raça abastarda"

5 Nas regiões destinadas a projetos de colonização no Sul havia populações indígenas e, em algumas áreas, também, posseiros "nacionais"; ambos os segmentos da população brasileira foram simplesmente ignorados - era como se não existissem!

6 Tavares Bastos (1976:62), por exemplo, defendeu a criação de uma agência especial do governo brasileiro em Nova Orleans para tentar trazer ao Brasil farmers americanos que pudessem "satisfazer a grande necessidade de lavradores inteligentes e ousados". 
sobre os caminhos da mestiçagem à brasileira. ${ }^{7}$ Tavares Bastos é a favor da imigração de "chins", desde que sejam encaminhados para o norte como trabalhadores rurais, apesar dos seus "defeitos" e "vícios". E conclui: a imigração chinesa deve ser deixada para a iniciativa particular, devidamente fiscalizada para não se repetir o "tráfico"; e o governo deve dirigir "seus esforços diretos e auxílios pecuniários ... para a formação de uma corrente de emigrantes dos povos civilizados" (Tavares Bastos, 1976:90). Civilizados, pois, só os europeus!

A hierarquização dos europeus, per outro lado, não obedece a critérios de natureza racial (afinal, são todos "brancos"): as referências dizem respeito, sobretudo, à condição camponesa. Empenhados na imigração destinada a projetos agrícolas, se interessavam principalmente pelos camponeses e artesãos. Neste caso, as experiências bem-sucedidas que serviram de modelo durante o Império eram colônias alemãs do Rio de Grande do Sul e Santa Catarina, como São Leopoldo, Blumenau e D. Francisca - e os "alemães" acabaram sendo o exemplo prático do colono eficiente. Aparecem, assim, no topo das hierarquias, embora houvesse interesse também num fluxo de agricultores norte-americanos e nos italianos. É interessante observar que franceses, ingleses e irlandeses são descartados em face de experiências mal-sucedidas em algumas colônias do Paraná e Santa Catarina. De modo geral, sendo todos brancos europeus, a forma de desqualificação opera com critérios que remetem à posição de classe, como pode ser visto também em relatórios de diretores de colônias. Invariavelmente, o termo usado para desqualificar é "escória" e os agenciadores são acusados de trazer da Europa aventureiros, lumpen e comunistas ao invés de camponeses morigerados. ${ }^{8}$

A miscigenação, como problema, ficou em plano secundário neste debate sobre políticas de colonização, até porque as chamadas "raças inferiores" foram deixadas à margem de todos os projetos oficiais ou particulares envolvendo imigrantes: "agricultura moderna" era coisa para civilizados brancos.

Ao direcionar os imigrantes para assentamentos em terras devolutas no Sul do País, ${ }^{9}$ o governo imperial acabou promovendo o estabelecimento de colônias inicialmente homogêneas - principalmente "alemãs" e "italianas" - com presença mínima de brasileiros. A estes se fizeram restrições, quase sempre constantes de alvarás e recomendações por ofício a diretores de colônias e chefes de Comissões de Terras e Colonização (e que não aparecem na legislação), que regulamentavam a concessão de terras, tais como: atestados de casamento (já que a concessão era "familiar") - espécie de comprovante de "moralidade" -, imponderáveis provas de "bom comportamento" e

7 As representações de parte da elite brasileira sobre miscigenação e imigração e as especulações sobre o "perigo amarelo" são analisadas em Skidmore (1976), Azevedo (1987) e Seyferth (1991).

8 Deve ser lembrado que estes agenciadores recebiam pagamento por indivíduo aliciado (diferenciado conforme idade e sexo), embora os contratos especificassem um número máximo de imigrantes. Um deles, Caetano Pinto Júnior, foi contratado na década de 1870 para trazer 100.000 imigrantes europeus para os projetos desenvolvidos pelo governo em Santa Catarina e Rio Grande do Sul. Sobre os preconceitos de classe acerca dos imigrantes "indesejáveis", vide Seyferth (1988).

9 Até 1889 a instalação de colônias em outras regiões foi ocasional, envolvendo um número pequeno de imigrantes: houve assentamentos no interior de São Paulo, em Minas Gerais (Teófilo Ottoni e Juiz de Fora) - considerados empreendimentos "fracassados"; no Estado do Rio (Petrópolis e Nova Friburgo) e no Espírito Santo. 
"escrúpulos", eufemismos que permitiram a exclusão, sobretudo, da população regional chamada "cabocla". Caboclos, negros, mestiços em geral e até imigrantes portugueses eram considerados apenas coadjuvantes do progresso a ser introduzido por uma agricultura "racional" - serviam para o trabalho "pesado" de desbravamento e desmatamento conforme opinião de Menezes e Souza (1875). Os pressupostos de inferioridade e a hierarquização baseada em elementos de natureza racial (como determinante de "capacidades") são mais do que óbvios quando está em jogo a idéia de "progresso" orientadora das políticas de colonização.

\section{DISCURSOS SOBRE IMIGRAÇÃO E RAÇA NO INÍCIO DA REPÚBLICA}

O eixo da discussão sobre política imigratória passa para a questão racial, de forma mais explícita, nas primeiras décadas da república, sempre vinculada à colonização - ou seja, o imigrante preferencial é aquele que pretende se fixar como agricultor ou trabalhador rural. O tema preponderante é o da assimilação associado à miscigenação enquanto processo histórico de formação de uma "raça" ou "tipo" nacional.

O Brasil já possuía uma ciência das raças, gestada desde 1860 , sob influência da obra de Paul Broca, eminente anatomista e antropólogo francês - conforme periodização e referências em Castro Faria (1952). Até 1877 são trabalhos esparsos, realizados no âmbito das escolas de medicina, versando sobre as origens das raças humanas e temas próximos. Em 1877 foi instituído o primeiro curso de Antropologia Física no Museu Nacional - lecionado por João Batista de Lacerda. A partir daí, os estudos sobre raças se tornaram mais sistematizados, tanto nos Museus como na Medicina Legal - os pesquisadores interessados, principalmente, na morfologia e classificação de tipos indígenas e de mestiços. Essa ciência tinha como premissa a desigualdade das raças e construiu hierarquias baseadas na superioridade da "raça branca". na inferioridade das "raças de cor" e nos "prejuízos" da mestiçagem embaralhada (termo pelo qual alguns intérpretes da formação racial brasileira se referiam à massa de "trabalhadores nacionais"). Os antropólogos seguiam o rigor metodológico e estatístico preconizado por Broca, que sistematizou a Antropometria e estava convencido da inferioridade dos não brancos como muitos outros cientistas da sua época preocupados com a elaboração de rigorosas hierarquias raciais. Por outro lado, até a Primeira Guerra Mundial, estavam em evidência as teses darwinistas sociais e o mito ariano (principalmente na forma inventada por Gobineau, Chamberlain e Lapouge), e a mestiçagem aparece como elemento negativo em todas elas. 10

Mas os cientistas brasileiros encontraram meios para contornar a visão negativa seguida pelo racismo para a mistura de raças ora classificadas como inferiores, ora como atrasadas: inventaram a tese do branqueamento e os mestiços "superiores"'! Nos termos

Dois dos principais pregadores científicos do arianismo estiveram no Brasil - Gobineau e Lapouge - e ambos se referiram negativamente àquilo que consideraram como "excessos de mestiçagem". Um terceiro. Louis Agassiz, também se mostrou pessimista com o futuro de um pais de raças misturadas. Claro que nossos próprios "pregadores" ficaram indignados, sobretudo com o vaticínio de Lapouge, que previu um "futuro negro" para o Brasil 
da sua versão "científica", através da memória apresentada por J. B. de Lacerda no Congresso Universal das Raças, Londres, 1911, como delegado do governo brasileiro (Lacerda, 1911), o branqueamento da raça era visualizado como um processo seletivo de miscigenação que, dentro de um certo tempo (três gerações), produziria uma população de fenótipo branco. ${ }^{11}$ Portanto, em termos gerais, o Brasil teria uma raça, ou um tipo ou, ainda, um povo (o conceito empregado não importa) nacional. Em suma, a característica que faltava para definir a nação. Sendo assim, os imigrantes tinham um papel adicional a exercer: contribuir para o branqueamento e, ao mesmo tempo, submergir na cultura brasileira através de um processo de assimilação.

O fluxo imigratório para o Brasil foi mais intenso entre 1880 e 1920, e a década de 1890 concentrou o maior volume de entradas de estrangeiros (que engrossaram as estatísticas imigratórias) - mais de um milhão e duzentos mil indivíduos (Carneiro, 1950), a maioria proveniente da Europa (sobretudo da Itália). Na virada do século, as estatísticas serviram para dar credibilidade à imaginada nação branca do futuro. Os assuntos da colonização e da imigração, assim, passaram a ser discutidos por cientistas de todos os matizes como uma "questão de raça".

"Assimilação" e "mistura" (ou "miscigenação", "caldeamento" etc.) são palavras-chave dos discursos nacionalistas num contexto de crítica às políticas de imigração e colonização implementadas durante o Império. Claro que o "monroísmo" e a propaganda ostensiva da Liga Pan-Germânica, bem como o acirramento dos nacionalismos europeus no período, além das doutrinas raciais já mencionadas, contribuíram para radicalizar posições xenófobas - dirigidas principalmente às etnias consideradas "inassimiláveis". O sistema de colonização do Império foi considerado um desastre por ter permitido a concentração de estrangeiros no Sul do País em "colônias homogêneas" que permaneceram à margem da sociedade nacional. Observações desta natureza foram comuns também no Império, como se pode observar em Carvalho (1874), não obstante sua posição favorável à imigração européia, em especial de portugueses; mas apesar do caráter genérico que remetia à "imigração", as "colônias alemãs" se tornaram o alvo mais sistemático do discurso xenófobo. Neste caso, o imigrante privilegiado do regime anterior (pelo menos pela parcela da elite comprometida com a colonização baseada na pequena propriedade familiar) se transformou em perigo potencial para a nacionalidade, tendo em vista sua "consciência nacional" pautada por valores estranhos à brasilidade.

Na prática, colônias "homogêneas" não existiam no final do século XIX: na maioria das regiões inicialmente povoadas por alemães e italianos, foram introduzidos imigrantes de outras etnias. Mas o número de brasileiros nestas regiões era quase insignificante - situação que não mudou com a República, nem mesmo na colonização do oeste do Rio Grande do Sul, Santa Catarina e do planalto paranaense, em grande parte realizada no século XX por companhias particulares apoiadas pelo Estado, onde os elementos assentados vinham das colônias antigas (filhos ou netos de imigrantes) ou eram

11 A concepção de seleção natural e social inspirada no darwinismo social presumia que os mestiços mais bem dotados (classificados como superiores) procurariam cônjuges de pele mais clara; para os "mestiços inferiores" e as "raças inferiores" (índios e negros) foi vaticinado o desaparecimento progressivo no contexto de uma civilização em progresso. Sobre o desenvolvimento da idéia de raça e concepções de mestiçagem no pensamento brasileiro, vide, entre outros, Skidmore (1976), Da Matta (198I), Seyferth (1991, 1995) e Schwarcz (1993). 
imigrantes, mas da qual a população brasileira regional foi excluída. ${ }^{12}$ A posição crítica em relação ao sistema anterior, portanto, não resultou em mudanças substantivas na política de colonização do Sul, nem mudou a direção das correntes imigratórias européias para o Norte, tal como exigido por alguns nacionalistas, em nome do equilíbrio racial. Entre os que acreditavam na possibilidade do branqueamento - apoiados nas estatísticas censitárias que apontavam para uma "inversão" da pirâmide demográfica herdada do império - podemos destacar Silvio Romero como exemplo significativo. Reportando ao "perigo alemão", denunciado dentro e fora do Brasil, ${ }^{13} \mathrm{em}$ alguns dos seus textos mais panfletários propôs que os imigrantes fossem distribuídos por todo o território nacional, em particular na região que chamou de "Brasil intermediário"14 - localizada do Maranhão ao Espírito Santo - que considerou a de "maior mestiçagem" com as duas "raças inferiores" (negra e índia), com predominância de "mulatismo" em alguns lugares e do "caboclismo" em outros.

O imperativo da imigração, assim, era de natureza racial porque aquela parte do Brasil "mais português" definharia "sem a inoculação do elemento estrangeiro". Como era comum na época, remete à América Central, mais especificamente à República Dominicana (embora o exemplo preferido de "atraso" associado à inferioridade racial fosse o Haiti) para servir como exemplo do futuro do Nordeste caso as correntes imigratórias contínuas fossem direcionadas para o Sul.

O "desequilíbrio regional" volta a ser discutido em outro texto panfletário publicado em 1906, onde investe contra o que considera a "crescente desnacionalização do Brasil meridional" verificada, principalmente, nas colônias alemãs:

destarte, o erro gravíssimo, o erro inexplicável dos governos brasileiros, o erro que nos há de trazer a perda das belíssimas regiões do Sul, foi se haver consentido na formação lenta por 80 dilatados anos, de fortes grupos da população que ficou irremediavelmente germânica, sem a menor fusão com as populações brasileiras. (Romero, 1906:44)

Neste mesmo texto, compara a invasão germânica do Império Romano com a colonização alemã no Sul - "meteram-se por todas as províncias, como hoje se metem pelo nosso Brasil meridional" (Romero, 1906:10). Esta figura da "invasão" já fôra empregada por articulistas de jornais brasileiros, conforme observação de Carvalho (1874:203). Enfim, nesta perspectiva, para que servem arianos conquistadores (conforme imagem de Gobineau, citado por Romero na sua obra mais conhecida, a História da Literatura Brasileira) se eles recusam a "fusão" com os nacionais. O "desequilíbrio" referido, sem dúvida, remete à questão racial relacionada a uma concepção de mestiçagem seletiva. Assim, a mistura do português com o índio e o negro, base da formação racial brasileira,

12 Sobre a exclusão dos nacionais nos projetos de colonização do Oeste, vide Renk (1990).

13 Expressão usada para fazer referência à possibilidade de uma secessão dos estados do Sul, ante a presença predominante de população de origem alemã, patrocinada pela Alemanha ou, simplesmente, dos riscos para a nacionalidade em face da presença de uma população não assimilada e falante de outra língua
(Gertz, 1991; Seyferth, 1994).

14 Romero (1902:53) dividiu o País em quatro "zonas etnográficas" - o Vale do Amazonas, o Far-west (Centro-Oeste), as províncias do Sul e o Brasil intermediário. Se dedica mais às duas últimas, em particular à terceira (Sul) por considerá-la muito distante, em termos culturais e raciais, da sociedade brasileira. 
foi conveniente para "garantir o trabalho indispensável à produção da vida econômica" e teve como "vantagens" a aclimatação ao novo meio, a civilização das raças menos avançadas, a preparação da "possível unidade das gerações futuras" (impossível sem mestiçagem), o desenvolvimento das "faculdades estéticas", da "imaginativa" e do "sentimento". 15

O que parece ser, a princípio, uma simples apologia da mestiçagem, não foge aos pressupostos sobre a inferioridade de negros, índios e da massa mestiça, quando diz, com convicção:

Manda a verdade, porém, afirmar que uma almejada unidade, só possivel pelo mestiçamento, só se realizará em futuro mais ou menos remoto; pois será mister que se deem poucos cruzamentos dos dois povos inferiores entre si. produzindo-se assim a natural diminuição destes, e se deem ao contrário em escala cada vez maior com indivíduos da raça branca ... E, mais ainda, manda a verdade afirmar ser o mestiçamento uma das causas de certa instabilidade moral na população, pela desarmonia das indoles e das aspirações no povo, que traz a dificuldade de formação de um ideal nacional comum. (Romero, 1949:294, 296, ênfase adicionada)

O papel do imigrante, portanto, está bem definido - concorrer para a formação de um tipo brasileiro, elemento da unidade nacional (que, paradoxalmente, vê comprometida pela "desarmonia das índoles" decorrentes da mestiçagem). Trata-se de uma construção racial - clarear a pele do brasileiro do futuro, pelo menos - pois a nacionalidade já tem sua cultura, sua língua e sua religião. Na concepção de Romero a nação brasileira do futuro deve ser uma civilização latina e branca, o que implica na assimilação dos imigrantes à formação lusitana do País. Assim, as políticas de imigração e colonização deviam estar voltadas para as gentes latinas - da Espanha, Portugal, Itália. Alemães irredutíveis à assimilação podiam ser bons para colonizar, mas constituíam ameaça à nacionalidade.

Lacerda também discute este papel racial da imigração branca, concluindo que ela coopera para a extinção dos mestiços, negros e índios no Brasil (Lacerda, 1911:29-31).

A noção de tipo racial domina estes escritos, associada a uma concepção de raça histórica inspirada em modismos racistas do período - a história brasileira como a história da formação de um tipo racial que aos poucos, seletivamente, se desembaraça dos tipos inferiores. As palavras "extinção" e "desaparecimento" são tão comuns a textos como estes quanto "raça" e "tipo", pois seus autores acreditavam que os tipos mestiços - isto é, caboclos, gaúchos, jagunços, mulatos, cafuzos, caborés etc. - e as raças inferiores ou destinadas à vida selvagem, conforme Lacerda (1912), cedo ou tarde sucumbiriam à civilização.

Nas classificações decorrentes, os brancos não são hierarquizados por sua capacidade em relação à produção agrícola (como em Menezes e Souza, por exemplo); o critério fundamental é a maior aproximação cultural - o que faz dos portugueses, espanhóis e italianos (nesta ordem) imigrantes ideais, de "civilização latina" e "assimiláveis".

15 Ao falar das qualidades estéticas dos mestiços se reporta diretamente a Gobineau (1853). Deve ser lembrado que o "pai" do mito ariano creditou o florescimento das aries em geral a uma mestiçagem leve, bem dosada, de sangue negro, mas acreditava na degenerescência provocada pela mestiçagem sem limites. 
Deve ser observado que o uso do termo raça não tem qualquer compromisso com os conceitos delineados na ciência, mais especificamente na Antropologia Física, e mesmo um antropólogo como Lacerda fala quase aleatoriamente em raça negra, tipo nacional, raça latina, tipo latino, tipos mestiços, e assim por diante. Os dois termos - raça e tipo - são utilizados para classificar e hierarquizar a população brasileira através de critérios de superioridade e inferioridade quase sempre associados a supostos traços do caráter geneticamente (racialmente) determinados. A cor da pele é o elemento preponderante que define as categorias raciais empregadas, mas a hierarquização é subjetivamente ancorada, num sentido civilizatório, na ordem moral. Daí o uso da expressão "mestiçamento moral" para denotar a influência africana "inoculada" na índole brasileira (Romero, 1949:294) e seus "efeitos negativos" também enumerados por Lacerda (1911) quando diz que os "vícios do negro" aviltaram o caráter dos mestiços. Na verdade, qualquer que seja a imagem construída de cada tipo ou raça, e apesar da crença nos bons resultados do processo de branqueamento pela miscigenação, há uma divisão bipartida onde, de uma lado, estão os brancos (assimiláveis ou não) e do outro todos os diversos graus de "inferiores" - pois mesmo a concepção de "mestiço superior"16 implica distanciamento seletivo por contraste com o civilizado pleno - o branco.

A maior intensidade da imigração européia nas duas últimas décadas do século XIX e a inexistência do tráfico de africanos desde 1850 alimentaram as especulações sobre o futuro "tipo brasileiro". E estas especulações podem ser encontradas em outro tipo de trabalho, mais diretamente associado às práticas da política de colonização com imigrantes. Num texto bastante referido ao Congresso Internacional das Raças, realizado em Londres em 1911 (e do qual Lacerda participou), Joaquim da Silva Rocha, chefe de seção da Diretoria do Serviço de Povoamento do Ministério da Agricultura, Indústria e Comércio, fez uma História da Colonização do Brasil (publicada pela Imprensa Nacional em 1918) com o intuito de condensar "a ação do governo brasileiro e dos seus agentes sobre esses dois importantes fatores do desenvolvimento econômico do País" (imigração e colonização), conforme o prefácio de Dulphe Pinheiro Machado dirigido ao Ministro J. Pandiá Calógeras. O que deveria ser um relatório sobre a legislação e as práticas de colonização com imigrantes desde a independência (mas também remetendo ao período colonial) é um texto entremeado por diversos capítulos dedicados à análise das correntes imigratórias reais e possíveis do ponto de vista da questão racial.

Existem muitos pontos em comum com o trabalho similar de Menezes e Souza publicado em 1875 - como a condenação da imigração asiática, considerada prejudicial à formação do "tipo brasileiro" (além dos problemas práticos relacionados ao assentamento de colonos). Mas tem algumas características bem específicas. Em primeiro lugar, toma como exemplo de colonização bem-sucedida as práticas colonialistas dos Estados imperialistas europeus na Ásia, África e Austrália - usando a palavra colonização como sinônimo de colonialismo, justificando este último em nome da superioridade mental dos brancos. Em segundo lugar, as medidas propostas para obter boa colonização remetem à

16 O conceito é de Nina Rodrigues, contemporâneo de Lacerda e Romero, mas cético com relação às possibilidades do branqueamento. Os mestiços superiores são definidos pela "predominância da raça civilizada na sua organização hereditária ou por uma combinação mental feliz", isto é, são indivíduos equilibrados e responsáveis (Rodrigues, 1938:216). 
questão da nacionalização dos imigrantes - como "dar sentido cívico à naturalização", garantir uma "tutela moral através do ensino público", ampliar as possibilidades do contato provendo as colônias com vias de comunicação mais adequadas etc. Em terceiro lugar, cita um grande número de autores europeus e norte-americanos que trataram tanto do tema da colonização como da raça, e adota a divisão de raças proposta por Le Bon primitivas (australianos), inferiores (negros, capazes apenas de rudimentos de civilização), médias (chineses, japoneses, povos semitas) e superiores (indo-europeus). A partir deste critério de desigualdade, defende a colonização com imigrantes europeus fazendo apreciações sobre as principais etnias que se estabeleceram no País: portugueses (forma com índios e negros as três raças que deram origem à nacionalidade, "ativos", "inteligentes", "resistentes ao sol" etc.); italianos (com sua propensão ao pastoreio e artes industriais); espanhóis ("sóbrios", "laboriosos", "perseverantes", "humildes" etc.); alemães (pelo seu "valor produtivo"). Faz, ainda, menção aos ingleses (que não emigram), franceses (que "se conformam com os costumes dos povos onde se estabelecem"), belgas, austro-húngaros (e sua "dedicação à lavoura"). É difícil imaginar como são operacionalizados por Silva Rocha os critérios que qualificam ou desqualificam imigrantes: lamenta o fato de a França não ser país de emigração (por ter suas próprias colônias) porque os franceses trazem consigo "os princípios de desenvolvimento e de progresso", embora não tenham a perseverança e paciência dos alemães e a energia dos ingleses, e logo depois desqualifica os belgas, cuja imigração poderia fracassar no Brasil por serem um povo voltado para a indústria manufatureira. Isto é, construiu uma hierarquia de imigrantes possíveis com base numa suposta aptidão "econômica" específica de cada nacionalidade. Nesta perspectiva, interessam principalmente os assimiláveis latinos - portugueses, italianos, franceses e espanhóis (e os "produtivos" alemães são inconvenientes por sua irredutibilidade étnica) e os que tem melhor desempenho na atividade agrícola e artesanal (Silva Rocha, 1918:56-75, vol. I).

Este tipo de exercício classificatório de etnias européias em função das suas aptidões colonizadoras não constitui novidade. O que chama a atenção neste texto (e nos outros que discutem "colonização" ainda no Império) é a ausência de referências mais demoradas aos trabalhadores nacionais, uma categoria já em uso no período, e aos negros e mestiços enquanto possíveis colonos no regime de pequena propriedade. Ou seja, sua participação em projetos de colonização sequer é considerado - mostrando que o esquema de classificação de raças de Le Bon foi levado a sério: supõe que as raças chamadas "superiores" são as únicas capazes de civilização. E, em nome da unificação do tipo nacional, Silva Rocha, citando Salvador de Mendonça, Cônsul do Brasil nos Estados Unidos, descarta os inferiores e só admite a introdução de asiáticos (as "raças médias" de Le Bon) desde que não sejam concedidas a eles "condições de permanência", isto é, não devem "fixar-se em nosso solo" (Silva Rocha, 1918:89, vol. I). Enfim, as "colônias de povoamento" precisavam de civilizados, mas estes, por sua vez, deviam ser nacionaliza-
dos.

Entre os comentários à legislação de 1850 a 1859 e de 1860 a 1869, Silva Rocha introduz uma discussão sobre a desnacionalização dos centros agrícolas e a unidade do tipo nacional. O significado desta localização do problema no texto tem relação com as críticas feitas ao regime monárquico porque permitiu a formação de colônias etnicamente homogêneas. O exemplo de desnacionalização é, mais uma vez, o das "colônias alemãs" e a solução aprcsentada se aproxima das proposições de Silvio Romero - tem, 
pois, relação com concepções claras de "equilíbrio racial" em todas as regiões do País. Diz Silva Rocha (1918:313, vol. I):

a permuta de população interestadual, sob as formas moral, intelectual e propriamente social, seria um elemento de prosperidade e grandeza de nossa nacionalidade, pois a importação, pelo sul, do elemento nortista levar-lhe-ia parte destes fatores, como o elemento sulista seria portador de outros. Isto para evitar que o elemento estrangeiro congregado em massa no território nacional não venha, em determinados pontos, fazer o meio, trazer os usos e os costumes da sua raça e muito menos ainda, sobrepujar a nossa ...

Mas, apesar de visualizar uma divisão bipartida do País, com a parte ao norte "manifestando os verdadeiros sentimentos de uma nacionalidade" e a parte sul onde a nacionalidade está ameaçada pela "promiscuidade dos elementos que a imigração européia lhe trouxe", não há indicação mais precisa de aproveitamento do elemento nacional nos projetos de colonização. Dedica-se, antes, a especular sobre a composição étnica do País, atribuindo o atraso na formação de um "tipo definitivo" de brasileiro à política de colonização anterior à república.

A "primitiva fusão de sangue" no território brasileiro - a das três raças "formadoras" - devia ser temperada com o elemento civilizador da imigração, o que, para Silva Rocha, não ocorreu. E propõe: "trata-se, agora, do aperfeiçoamento da espécie; trata-se de nacionalizar a população existente no Brasil; trata-se, finalmente, de obter sua representação por um tipo definitivo" (Silva Rocha, 1918:5, vol. II). Na perspectiva apresentada, a unidade nacional estava ancorada a esta idéia de um "tipo racial" representativo do brasileiro, que o Brasil Imperial inviabilizou ao permitir que os elementos civilizados ficassem isolados no Sul. Na perspectiva sugerida, o "elemento civilizado" devia ser introduzido "no meio dos que não o fossem", mas nunca permitindo uma preponderância sobre os usos e costumes nacionais (aí compreendida a língua nacional). Assim, por um lado, os governos monárquicos são acusados de "descaso" pelo futuro da nacionalidade e, por outro, atribui parte do "atraso" à colonização portuguesa - que não teria seguido os princípios do capitalismo. ${ }^{17}$ A grandeza do Brasil, portanto, foi retardada porque ficou longo tempo "sem elementos de progresso e desenvolvimento", faltando, no início, o "elemento civilizador".

Percebe-se, assim, que o elemento privilegiado para colonizar o País é o imigrante europeu, mas não o português, que considera avesso à lavoura e ao capitalismo. De qualquer forma, a preferência pelos europeus está evidente na legislação republicana sobre colonização analisada na última parte do trabalho e nos próprios juízos de valor expressos pelo autor, que vê o "povoamento do solo nacional" ancorado à "propaganda necessária a este povoamento" fora do território brasileiro (Silva Rocha, 1918:225, 231, vol. II). "Fora" significa explicitamente "Europa" - já que outras correntes imigratórias são descartadas. Todas as referências a colônias específicas e à colonização em geral remetem à imigração - e o problema central discutido a partir de citações freqüentes de auto-

17 O autor não usa diretamente o termo, mas reporta à Adam Smith (Riqueza das Nações) para dizer que a colonização portuguesa (Brasil Colônia) não seguiu a "fórmula racional sobre o trabalho" sintetizada em dois princípios - o "trabalho aumenta em extensão, primeiro em razão do maior acúmulo de capitais; segundo pela maneira pela qual são esses capitais empregados" (Silva Rocha, 1918: 13, vol. II). 
res como Alberto Torres e Coelho Neto, entre muitos outros, é o da "desnacionalização dos centros agrícolas" (vale dizer, das colônias européias do Sul).

Outras questões relacionadas ao povoamento ficam em plano secundário - caso das chamadas "colônias militares" e, principalmente, a questão indígena (mencionada apenas através de uma breve análise sobre a catequese). Mas é significativo que a "questão indígena" também é considerada como um problema de nacionalização, e aos missionários se atribui o dever de aproximar os índios da "pátria". 18

A concepção de "tipo nacional" atravessa toda esta História da Colonização do Brasil - num formato muito próximo às concepções de Silvio Romero e J. B. de Lacerda: a unidade nacional vinculada ao povoamento do território por imigrantes brancos encarregados de civilizar uma população considerada inferior, sem destruir aquela outra base da nacionalidade que é a cultura latina e a língua portuguesa. Tudo o que pode ameaçar esta unidade e a formação do tipo nacional especificamente brasileiro é criticado: a homogeneidade das "colônias alemãs", a imigração asiática, a exclusividade da imigração portuguesa. Os dois últimos temas encerram as especulações sobre imigrantes possíveis e indesejáveis. No caso dos portugueses, responde às propostas de se dar a eles exclusividade com uma negativa de natureza econômica. Para Silva Rocha os portugueses detestam a agricultura, mesmo quando oriundos do meio rural - sua vocação "está no sangue" e é comercial - portanto, não serve para colonizar. Não se posicionou contra a imigração portuguesa, apenas a excluía do regime de colonização; mas não tem a mesma opinião quanto aos asiáticos. Neste caso, critica as empresas particulares que estavam introduzindo imigrantes japoneses em São Paulo, repudiando "semelhante forma de colonização". Chineses e hindus, também cogitarência de mão-de-obra (caso do federação desejosas de resolver caconsiderados como ameaca momento usa a palavra "branqueamento", mas esta "unificação do tipo nacha em nenhum exatamente a mesma pretendida por Lacerda e Romero e outros autores do mesmo período - e os imigrantes bons para colonizar e povoar são brancos europeus com
tendências assimilacionistas.

\section{CONSIDERAÇÕES FINAIS}

A História da Colonização do Brasil elaborada por Silva Rocha é demonstrativa da influência das teorias raciais e dos nacionalismos constituídos na Europa na segunda metade do século XIX, traduzida, principalmente, pela preocupação obsessiva com a formação de um tipo nacional, apesar do caráter mais ou menos técnico assumido ao longo de povoamento) do território brasileiro. A concepção deste tipo nacional é a mesma (e, consequentemente, contrada em muitos outros autores que, em nome da ciência das raças, imaginaram a possibilidade do branqueamento da população, num processo seletivo que tinha no imigrante europeu a sua peça fundamental. 
O funcionário graduado do Ministério da Agricultura, Indústria e Comércio, assim como autores mais conhecidos do pensamento brasileiro, como Lacerda e Romero, acreditava que uma nação moderna precisava ter sua raça e sua civilização. O Brasil é pensado como nação ainda em formação - atribuindo-se o "atraso" desta formação ao desinteresse do regime monárquico pela nacionalidade. É neste sentido que fazem suas críticas ao sistema imperial de colonização, que também pode ser lido como sistema de povoamento de territórios considerados desabitados (dentro da noção de "vazios demográficos"), já que as populações regional e indígena raramente são mencionadas, ou apa-
recem como entraves à implantação de um modelo de agricultura moderna.

Na prática, a mudança de regime político não transformou substantivamente a forma de colonizar: colonização com pequena propriedade familiar - portanto, a formação de núcleos agrícolas em terras devolutas - continuou sendo feita com imigrantes europeus, e a introdução dos primeiros japoneses em 1908 criou mais uma das muitas polêmicas, trazidas do século XIX, relacionadas aos "perigos" da imigração asiática. Na concepção de processo civilizatório implícita nos autores citados, o progresso era considerado incompatível com a composição étnica da população nacional. Resumindo, no Império como na República, antes ou depois da abolição da escravidão, a massa de trabalhadores nacionais era pensada como racialmente inferior, embora a ela fosse atribuída
a missão de transformar os imigrantes em brasileiros.

As contradições são evidentes no conjunto de pressupostos que levaram ao privilegiamento do imigrante europeu como colonizador ideal porque era necessário conciliar uma concepção de nação calcada na idéia de raça e progresso com a realidade da mestiçagem e a presença de negros e índios na população em números considerados excessivos. A primeira das suposições de exclusão estabeleceu a incompatibilidade das raças chamadas inferiores com uma economia moderna, e não foi por outra razão que os projetos coloniais receberam um número muito pequeno de brasileiros. Como pode ser observado, a imigração aparece como imperativo para impulsionar as forças produtivas do tos, onde civilização é sinônimo de progresso.

Este formato, porém, não resolvia o proble.

branqueamento formulados no iníciolvia o problema do "tipo nacional" e os cânones do to ou miscigenação dos imigrantes da república exigiam a assimilação e o caldeamenhierarquização dos imigrantes preferení a quase inversão das prioridades, percebida na acordo com sua presuntiva capacidade de cultura moderna, que tinha como modelo produzir uma economia capitalista, uma agritência de preocupações com a questão farmer americano. Isto não significa a inexispopulação não era tão imperativo antes racial, mas certamente o branqueamento da formalização do branqueamento a partir 1888. Nas primeiras décadas da República, a vou a um novo formato de classificação do dogmas associados à "ciência das raças" leou menor inclinação de cada etnia à assimilação àntes europeus, desta vez pela maior mães foram excluídos da condição de imigranaco e à miscigenação. Desta forma, os alenica assumida nas regiões onde ficaramgrantes preferenciais diante da organização étcorrentes imigratórias não brancas cogitam como colonos. Mas nos dois momentos as o problema da mão-de-obra na grandegitas por alguns setores como forma de resolver nalidade. O tipo nacional imaginado lavoura foram consideradas um risco para a naciorazão apresentada para condenar a vinda incompatível com uma imigração não branca, 
como representantes de civilizações decadentes que podiam atrasar o processo histórico de formação racial do brasileiro. Quanto aos africanos, sequer foram cogitados como imigrantes - motivo provável da sua "ausência" neste debate.

\section{REFERÊNCIAS BIBLIOGRÁFICAS}

ARENDT, H., 1976. As Origens do Totalitarismo. II Imperialismo, a Expansão do Poder. Rio de Janeiro: Documentário.

AZEVEDO, C. M. M., 1987. Onda Negra, Medo Branco. Rio de Janeiro: Paz e Terra.

BANTON, M., 1977. The Idea of Race. Londres: Tavistock.

BOEHM, M., 1933. Nationalism. In: Encyclopaedia of the Social Sciences, vol. XI, New York: Macmillan.

CARNEIRO, J. F., 1950. Imigração e Colonização no Brasil. Rio de Janeiro: FNF, Cadeira de Geografia, Publicação Avulsa, n⿳o 2.

CARVALHO, A., 1874. Estudo sobre a Colonização e Emigração para o Brasil. Porto: Typographia do Comércio.

CASTRO FARIA, L., 1952. Pesquisas de antropologia física no Brasil. Boletim do Museu Nacional, Série Antropologia, 13:1-106.

DA MATTA, R., 1981. Relativizando. Uma Introdução à Antropologia Social. Petrópolis: Vozes.

DAVATZ, T., 1941. Memórias de um Colono no Brasil. São Paulo: Livraria Martins.

GELLNER, E., 1983. Nations and Nationalism. Londres: Blackwell.

GERTZ, R., 1991. O Perigo Alemão. Porto Alegre: Ed. da Universidade/UFRGS.

GOBINEAU, A., 1853. Essai sur llnégalité des Races Humaines. 4 vols. Paris: Firmin Didot.

HOBSBAWN, E. J. 1991. Nações e Nacionalismo desde 1780. Rio de Janeiro: Paz e Terra.

LACERDA, J. B., 1911. Sur les Métis au Brésil. Paris: Imprimerie Devouge.

MAUSS, M., 1969. La Nation. In: Oeuvres, vol. 3. Paris: Minuit.

MENEZES E SOUZA, J. C., 1875. Theses sobre a Colonização do Brasil. Rio de Janeiro: Typographia Nacional.

RENK, A., 1990. A Luta da Erva: Um Oficio Étnico da 'Nação Brasileira no Oeste Catarinense'. Dissertação de Mestrado, Rio de Janeiro: PPGAS, Museu Nacional, UFRJ.

RODRIGUES, R. N., 1938. As Raças Humanas e a Responsabilidade Penal no Brasil. São Paulo: Cia. Ed. Nacional.

ROMERO, S., 1902. O Elemento Português no Brasil. Lisboa: Tipografia da Cia. Ed. Nacional.

ROMERO, S., 1906. O Alemanismo no Sul do Brasil. Seus Perigos e Meios de os Conjurar. Rio de Janeiro: Heitor Ribeiro.

ROMERO, S., 1949. História da Literatura Brasileira. Vol. 1. Rio de Janeiro: José Olympio. 
SCHWARCZ, L. M., 1993. O Espetáculo das Raças. São Paulo: Companhia das Letras.

SEYFERTH, G., 1988. Colonização e conflito. In: PPGAS/Museu Nacional, Comunicação, 10:1-72.

SEYFERTH, G., 1991. Os paradoxos da miscigenação. Estudos Afro-Asiáticos, 20:165-185.

SEYFERTH, G., 1994. O incidente do Panther (Itajaí, SC) 1905: estudos sobre ideologias étnicas. In: PPGAS/Museu Nacional, Comunicação, 4:15-80.

SEYFERTH, G., 1995. A invenção da raça e o poder discricionário dos estereótipos. Anuário Antropológico 1993, pp. 175-203.

SILVA ROCHA, J., 1918. História da Colonização do Brasil. 2 vols. Rio de Janeiro: Imprensa Nacional.

SKIDMORE, T. E., 1976. Preto no Branco. Raça e Nacionalidade no Pensamento Brasileiro. Rio de Janeiro: Paz e Terra.

SMITH, A. D., 1986. The Ethnic Origins of Nations. Oxford: Blackwell.

SOUZA LIMA, A. C., 1992. Um Grande Cerco de Paz. Poder Tutelar e Indianidade no Brasil. Tese de Doutorado, Rio de Janeiro: PPGAS, Museu Nacional, UFRJ.

TAVARES BASTOS, A. C., 1976. Os Males do Presente e as Esperanças do Futuro. Estudos Brasileiros. São Paulo: Cia. Editora Nacional.

WEBER, M., 1971. Économie et Société. Paris: Plon. 


\title{
4 DOS MALES QUE VÊM COM O SANGUE: AS REPRESENTAÇÕES RACIAIS E A CATEGORIA DO IMIGRANTE INDESEJÁVEL NAS CONCEPÇÕES SOBRE IMIGRAÇÃO DA DÉCADA DE 20
}

\author{
Jair de Souza Ramos
}

\section{INTRODUÇÃO}

De meados do século XIX até as primeiras décadas do século XX, a diplomacia brasileira se esforçou por desenhar um retrato positivo do Brasil junto ao público europeu e, em menor medida, também ao dos E.U.A., por meio de livros, palestras e exposições, com o objetivo de atrair capitais e imigrantes (Skidmore, 1976:142). Sobretudo a partir da década de 1890, o objetivo dessa propaganda era trazer trabalhadores supostamente mais aptos que o trabalhador nacional ao regime de trabalho livre que se consolidaria com o fim da escravidão (Azevedo, 1987:60).

Este retrato foi predominantemente construído em torno das "riquezas naturais" do Brasil, mas contemplou também a idéia de que aqui inexistiam conflitos sociais e raciais. A ausência deste último tipo de conflito foi definida a partir da idéia de que a colonização portuguesa se caracterizou pela inexistência de preconceitos raciais, do que a miscigenação seria o melhor exemplo (Skidmore, 1976:147). E esta visão não foi construída somente como "artigo de exportação", tendo sido largamente partilhada por intelectuais e políticos do Império e da Primeira República.

Esta propaganda foi um dos instrumentos de que a República se serviu para atrair aquelas populações que, na condição de minorias no interior dos estados nacionais construídos e destruídos desde o século XIX, viviam a experiência das perseguições religiosas e étnicas, sendo tangidas de um ponto a outro da Europa por conta das constantes redefinições de fronteiras e lealdade políticas. Estas pessoas eram atraídas pela perspectiva de refazer suas vidas fora da Europa. ${ }^{1}$ Todavia, as populações européias não foram as únicas a se sentirem atraídas por estas promessas de paz e trabalho. Estas ofertas seduziram também os imigrantes japoneses que chegaram ao País nas primeiras décadas do século XX e alcançaram ainda alguns jornais e intelectuais negros nos Estados Unidos (Lesser, 1994:84; Hellwig, 1988:60; Meade \& Pírio, 1988:91). Este foi um dos motivos

Em Carcamanos e Comendadores, Mario Careli (1985:23) revela a importância na emigração italiana dos mecanismos de expulsão a partir das redefinições políticas na Itália. Por outro lado, Willens (1980:110) mostra o alcance da propaganda na construção da imagem que os imigrantes alemães possuíam do Brasil. 
que levou um grupo de afro-americanos a se organizar em uma companhia de colonização e entrar em negociações, em 1921, com o então Presidente do Estado do Mato Grosso, visando obter terras para a fundação de uma colônia.

Em princípio, a vinda ao Brasil destes imigrantes da América e do Japão, países reputados como civilizados e com grande experiência de trabalho livre, deveria encaixarse, senão perfeitamente, pelo menos parcialmente, nos objetivos confessados da propaganda e da política imigratória. Contudo, tanto a realidade da imigração japonesa quanto a possibilidade da imigração negra receberam severas críticas em função dos supostos riscos aos quais o Brasil estava exposto pela falta de controle sobre a entrada de imigrantes, sobretudo negros e amarelos (Skidmore, 1976).

Qual o fundamento destas críticas? Melhor dizendo, quais fundamentos, para além da intenção confessa de obter uma mão-de-obra apta ao trabalho livre, das políticas imigratórias brasileiras?

O que parte significativa da literatura sobre imigração no Brasil revela é que a intenção de obter trabalhadores livres esteve submetida a um critério que poderíamos chamar provisoriamente por racial - explicaremos mais adiante qual o significado com que empregaremos o termo - que definiu a preferência pelo imigrante branco e europeu e a rejeição da imigração das raças não brancas. ${ }^{2}$ Como nos mostra Seyferth (1991), desde a lei de terras de 1850 definiu-se o imigrante ideal como " "...branco, camponês, resignado...", ao passo que eram tidas como indesejáveis "as raças atraşão, não civilizadas e inferiores..." (Seyferth, 1991:165-166). Com esta observaimigratórias desde o Impérionça de um cálculo racial na orientação das políticas do Sul do País quanto à zona cafee metade do século XIX, tanto em relação às áreas lo foi tributário da idéia de caldeatra de São Paulo (Seyferth, 1991:167). Este cálcu"tipo brasileiro" física e culturalmento das raças no sentido da constituição de um

Em contraposiça a culturalmente homogêneo. ${ }^{3}$

ma recorrente na literatura outra representação que é a do "imigrante gostaríamos de assinalar a existência de uma negativamente populações e indivíduos, tendo sidojál". Esta representação qualificou que vão da raça às convicções políticas dos imigrantestruturada numa série de critérios parcialmente, tentaremos evidenciar neste artigo ${ }_{4}$ antes, critérios estes que, pelo menos vel e do indesejável, pautaram tanto as políticas ${ }^{\mathrm{E}}$ ambas as representações, do desejádas de posição acerca do tema.

Assim, em todo o período da imigração de massa, de 1880 a 1930 , creditou-se ao imigrante branco europeu, com base na teoria do branqueamento, o papel de ingrediente fundamental na construção de um povo e de uma raça brasileira (Hall, 1969:37), ao mes-

Vide Seyferth (1991), Skidmore (1976), Schwarcz. (1993) e Azevedo (1987), para citar parte da literatu-
ra.

\footnotetext{
Desse modo, a autora chama a atenção para o fato de que, nos debates sobre imigração, aspectos objeti-
vos, tais como o estabelecimento trabalhador livre, foram muitas vezes supias de pequenos proprietários ou a substituição do escravo pelo imigrante europeu e suas implicações na formad̃os pela ênfase dada ao papel branqueador atribuído ao Provavelmente a expressão mais conteciçação do povo brasileiro (Seyferth, 1991:174). gração que proibia a entrada de "indígenas da Á representação seja a primeira lei republicana sobre imi-
} 
mo tempo em que se supunha prejudicial a entrada de determinados imigrantes no País. Ambas as suposições conformaram as ações do Estado brasileiro no sentido de, por um lado, incentivar a imigração européia por meio de propaganda no exterior e de benefícios legais relacionados à posse da terra; por outro, interditar ou restringir a imigração daque-
les povos considerados "raças inferiores".

Tratava-se aí de ver na mistura dos imigrantes brancos com os mestiços brasileiros a operação por meio da qual se daria a regeneração da raça, produzindo-se um povo homogêneo. A entrada de sangue branco e a conseqüente depuração do sangue negro pela mestiçagem garantiriam, assim, a "correção" dos componentes étnicos que fundaram o Brasil, produzindo um "tipo" racial brasileiro mais eugênico, porque possuidor de maior quantidade de sangue branco. Esse futuro tipo brasileiro teria como principal virtude fornecer um patamar mais elevado sobre o qual o povo brasileiro construiria sua unidade racial e cultural, e também garantir uma evolução futura do país pela melhoria
dos tipos raciais que o compunham. ${ }^{6}$

Este acento sobre a unidade física e cultural que se buscava obter por meio da imigração européia nos permite dar um primeiro passo para entender o que significa o termo "raça" nestas concepções que orientaram a política imigratória.

Tem-se chamado a atenção para o fato de que o discurso sociológico e antropológico no século $X X$ foi construído por sobre uma separação entre o biológico e o cultural na explicação dos fenômenos sociais e por uma opção pelo segundo (Ortiz, 1985; Laplantine, 1991:63). Contudo, como mostra a literatura mais recente, esta separação não se revela tão nítida no que se convencionou chamar "o pensamento social brasileiro". Assim,
Lesser sublinha o fato de que...

...raça, ao menos na primeira metade do século 20, não era meramente um questão de cor de pele. Realmente minha análise questiona diversas suposições gerais sobre gua, nacionalidade rertamente, ela mostra que a questão 'racial' inclui etnia, línEste mesmo entrelacamento entre (Lesser, 1995:308, ênfase adicionada) ${ }^{7}$

Este mesmo entrelaçamento entre características físicas e mentais das "raças" aparece na análise que Maio faz da presença do neolamarckismo nas formulações de Gilberto Freyre acerca do judeu em Casa-Grande \& Senzala (Maio, 1995:85). Neste texto, o autor chama a atenção para o fato de que a idéia de adaptabilidade, um dos eixos básicos "da teoria lamarckista, permitiu a Freyre a formulação de um conceito bastante plástico de mentais, ambas transmitidas pelo "sangue", e que se transformam no processo de adap-
tação à natureza e ao empreendimento colonial.

As expressões imigrantes "desejáveis" e "indesejáveis" aparecem, inclusive, quase como categorias na-
tivas no discurso, citado por Jeffrey Estado Novo que criticava a política de cotas por nacionalidade conselho de imigração e colonização de mando que as cotas "restringem o ingresso de raças desejáveis e favorecem pela constituinte de 34 , afirser, 1995:301). A partir daí, a prática ou não da miscigenação - bem como os tipos que ela viria a produzir - e a disponibilidade à assimilação funcionaram como valores de referência ao estímulo e à crítica de todos os empreendimentos migratórios, até mesmo dos "brancos" (Seyferth, 1991).

Caso não indicado ao contrário, são minhas as ênos" (Seyferth, 1991). longo deste capítulo. 
Segundo o autor:

... conceito chave é o de adaptação. É nesta chave lamarckista que poderia ser compreendido o perfil judaico delineado acima, ou seja a combinação entre raça e cultura, entre hereditariedade condições fisicas e psíquicas, realismo econômico e controle dos excessos de espírito militar e religioso na formação brasileira. (Maio, 1995:95)

O que esta literatura nos permite assinalar é a presença, mesmo sem alcançar o grau de sofisticação do discurso de Freyre, de inúmeras sínteses, as mais variadas e ecléticas possíveis, entre o biológico e o cultural, que aparecem por detrás do termo raça no discurso de intelectuais e políticos brasileiros na primeira metade do século XX. Estas observações nos permitem propor como ponto de partida deste artigo a hipótese de que raça foi predominantemente utilizada durante o período da imigração de massa, menos no seu sentido estritamente biológico do que como termo que identificava populações que supostamente carregavam uma unidade física e cultural.

Mas de que modo estas concepções de raça conformaram concretamente as tomadas de posição, e mesmo algumas das iniciativas do Estado brasileiro, sobre a imigração de massa, nos anos 20? Qual o conteúdo desta representação do imigrante indesejável? E de que modo populações concretas foram alvo desta classificação?

Nosso objetivo neste artigo é responder, pelo menos em parte, a estas perguntas através da análise de três desdobramentos da tentativa de imigração dos afro-americanos em 1921. O primeiro momento a ser analisado é o da reação da diplomacia brasileira à iniciativa dos negros norte-americanos; o segundo é o da apresentação de projetos de restrição racial à imigração das "raças inferiores", o que coloca em cena também a questão do imigrante japonês; o terceiro é um dos frutos do debate sobre estes projetos: o inquérito sobre imigração e raça da Sociedade Nacional de Agricultura (SNA), de 1925.

O que tentaremos fazer em cada um destes momentos é identificar as representações e práticas que corporificam a categoria do imigrante indesejável. Não se tratará aqui, simplesmente, de assinalar quais as populações que são classificadas como indesejáveis e sim identificar as representações que formam o eixo desta classificação. Isto porque, e esta é uma hipótese básica deste artigo, "desejáveis" e "indesejáveis" não são nomes que designam determinadas populações de uma vez por todas, são sim categorias que são mobilizadas por agentes sociais para classificar as populações imigradas. ${ }^{8}$ Estas categorias foram mobilizadas tanto por intelectuais e políticos brasileiros quanto pelos próprios imigrantes nos processos de luta simbólica que envolveram a imigração. Vale dizer que a classificação de uma população como desejável ou indesejável não se tratava de algo dado de uma vez por todas, mas dependia sim de uma negociação simbólica entre os agentes envolvidos na imigração. Este processo de negociação simbólica será observado com mais detalhes na seção em que discutimos o debate sobre a imigração japonesa. 8 O Aurélio Eletrônico (1994) define nome como "palavra(s) com que se designa pessoa, animal ou coi-
sa" e categoria como "classe, qualidade, ordem". 


\section{OS LIMITES DO PARAÍSO RACIAL}

Na longa história que une classificações raciais e políticas imigratórias no Brasil, um dos episódios mais reveladores da representação do imigrante indesejável gira em torno da tentativa de um grupo de cidadãos norte-americanos, descendentes de africanos, de imigrar para cá, em 1921, e das reações que se seguiram a esta tentativa.

Como nos mostram Meade \& Pírio (1988), este episódio inicia-se com a divulgação, em jornais norte-americanos, de propagandas do governo brasileiro acerca dos atrativos que o país oferecia aos imigrantes. Esta propaganda acabou sendo encampada por jornais dirigidos ao público negro nos E.U.A. Segundo os autores:

Independente de esforços oficiais do governo brasileiro, o Baltimore Afro-American publicou em 1920 os detalhes de uma oferta do Ministério de Agricultura brasileiro em que eram prometidos passagens, acomodações e crédito de longo prazo para trabalhadores americanos fisicamente aptos e agricultores que desejassem se estabelecer no Brasil. (Meade \& Pírio. 1988:87)

E o interesse específico do jornal em reproduzir estas informações residiu na crença, expressa aos leitores, de que o Brasil era um paraíso racial que oferecia ilimitadas oportunidades, visto que “...não existe 'linha de cor' como se conhece na América ... Um homem negro pode ser presidente do Brasil e não desperta mais atenção do que a eleição de um homem branco aqui" (Meade \& Pírio, 1988:87).

Esta mesma imagem foi partilhada por inúmeros jornais e ativistas negros dos E.U.A. ${ }^{9}$ E sua importância vinha do fato de vir ao encontro da saída emigracionista desenvolvida pelo movimento negro em resposta à violência racial institucionalizada através das leis Jim Crow. Estas leis, ao atingirem direitos civis e políticos da população negra no final do século XIX, forneceram suporte ao aparecimento de projetos emigracionistas, parte deles orientados pelo ideal de um nacionalismo negro que tinha como objetivo fundar repúblicas negras fora dos E.U.A. (Meade \& Pírio, 1988:86).

E estes projetos recaíram sobre o Brasil a partir do momento em que os projetos anteriores em relação à África fracassaram. Além disso, como acreditavam líderes negros como Cyril Brigs, a América Latina, e em especial o Brasil, eram lugares em que o predomínio das "raças de cor" poderia servir de base à fundação de uma república negra a qual, por sua vez, deveria servir de inspiração à luta anticolonial das massas africanas (Meade \& Pírio, 1988:89).

Parcialmente fundados nessas expectativas - as outras expectativas diziam respeito às possibilidades econômicas abertas, num país onde se supunha inexistir preconceito racial, a homens negros instruídos e civilizados - um grupo de negros norte-americanos de Chicago se propôs a comprar terras no Estado de Mato Grosso para estabelecer uma colônia. Para tal, estes imigrantes fundaram uma companhia de colonização de nome "Brazilian American Colonization Sindicate" - BACS (Lesser, 1994:84) e basearam suas pretensões nos acordos de imigração entre Brasil e Estados Unidos, que facultavam aos cidadãos norte-americanos o direito de entrar e se estabelecer no Brasil, a despeito de raça, etnia ou religião (Lesser, 1994:81). 9 Para uma relação completa dos jornais e ativistas, vide o referido artigo de Meade \& Pírio (1988) e Hell-
wig (1988). 
Sua iniciativa enfrentou resistências muitos concretas no Brasil. Dos jornais vieram acusações de um suposto plano do governo norte-americano de enviar para o Brasil toda a sua população negra, fato que, em plena vigência da ideologia do branqueamento, implicaria um prejuízo irreversível para a suposta regeneração racial que a introdução do imigrante branco vinha operando. O governo de Mato Grosso, por sua vez, imediatamente reagiu à informação de que os colonos norte-americanos eram negros com o cancelamento das concessões que haviam sido oferecidas ao BACS (Skidmore, 1976:212). Por fim, o Itamarati tratou de prevenir-se contra qualquer entrada destes imigrantes no Brasil, negando seus vistos diplomáticos (Lesser, 1994:84). O que se revela em cada uma destas reações é a figura do imigrante racialmente indesejado como uma decorrência necessária do ideal de branqueamento que orientava as políticas imigratórias brasileiras.

Estas restrições aos imigrantes afro-americanos foram conduzidas pela diplomacia brasileira. Como nos mostra Lesser (1994:85), o ministro das Relações Exteriores, José Manoel de Azevedo Marques, enviou, no mesmo ano de 1921, mensagens confidenciais à embaixada brasileira em Washington e aos consulados em Chicago, St. Louis, Nova Iorque, Nova Orleans, Baltimore e São Francisco - e também ao consulado em Barbados - ordenando que fossem recusados vistos a quaisquer imigrantes negros
que o solicitassem.

Contudo, as mensagens foram descobertas e questionadas pela BACS que, baseando-se nos tratados que regulavam a migração entre os dois países, buscou obter uma revisão da atitude do governo brasileiro (Lesser, 1994:88). Este teve, então, que enfrentar o problema publicamente, sendo forçado a justificar a proibição. A diplomacia brasileira, porém, não recorreu em momento algum à argumentação racial. Durante todo o tempo enfatizou-se a defesa da soberania brasileira nos termos de um discurso nacionalista que

gratória brasileira (Lesser, 1994:87).
. norte-americanos?

A primeira delas já foi por nós referida. Diz respeito ao predomínio da teoria de branqueamento, o que implicava a crença de que o imigrante branco e europeu era fundamental para a regeneração racial do trabalhador nacional e também para sua civilização. Este pressuposto implicava a exclusão, em princípio, das populações não brancas dos benefícios concedidos à imigração.

Todavia, este pressuposto mais geral do branqueamento não é capaz, sozinho, de explicar integralmente as tomadas de posição concretas, sobretudo neste caso específico dos negros de Chicago. Neste caso, a explicação para a atitude do governo brasileiro deve ser buscada também em uma outra representação: a de que o negro norte-americano
traria o ódio racial para o Brasil.

Efetivamente, como nos mostram Meade \& Pírio (1988:95), alguns dos projetos de colonização no Brasil estavam atravessados por um black nacionalism que tinha como um de seus pressupostos a idéia de que os negros deveriam governar as terras onde eram a maioria da população. E estes movimentos, incluindo a iniciativa do BACS, eram alvo de investigação por parte do governo americano. Segundo estes autores, aparentemente o FBI avisou o governo brasileiro acerca das atividades do BACS, e da presença de ativistas e das idéias do black nacionalism na origem da sua iniciativa
emigratória (Meade \& Pírio, 1988:96). 
Assim, ter-se-ia desenvolvido uma colaboração entre os dois governos a partir de um mesmo temor quanto à natureza da atividade política destes grupos negros. Em ambos os governos temiam-se os propósitos de subversão da hierarquia racial que conduziam iniciativas como a do BACS. E no caso do governo brasileiro, havia, como veremos na próxima seção, o temor, em especial, de que estes imigrantes pudessem disseminar entre os negros brasileiros uma cultura de violência racial. E foi esse temor que levou alguns deputados a um esforço para que a restrição à entrada dos imigrantes negros se tornasse definitiva. Esse esforço é o que passamos a analisar.

\section{OS PROJETOS DE RESTRIÇÃO Ȧ IMIGRAÇÃO E OS DEBATES PARLAMENTARES}

As reações à tentativa dos afro-americanos de imigrarem para o Brasil não se resumem às ações diplomáticas; o caso repercutiu também no Congresso Nacional. Alguns deputados, não considerando suficientes as medidas tomadas pelo Itamarati e pelo presidente do Estado de Mato Grosso, resolveram propor leis que impedissem, definitivamente, a entrada de imigrantes negros. Este foi o caso dos deputados Cincinato Braga (SP) e Andrade Bezerra (PE) que, reagindo prontamente às notícias sobre o caso, ăpresentaram ainda em 1921 um projeto de lei à Câmara com apenas dois artigos, cujo conteúdo era a proibição, em caráter absoluto, da entrada de imigrantes negros no País.

$\mathrm{Na}$ verdade, este projeto retomava o espírito de uma lei republicana, de 1891, que, sem falar em raça, proibia a vinda de imigrantes nativos da África e da Ásia. Essa lei havia sido revogada em 1907, o que propiciou a chegada de japoneses para as lavouras cafeeiras de São Paulo (Skidmore, 1976:217). O projeto de Cincinato Braga era, contudo, mais amplo e mais explícito, pois visava erradicar totalmente a possibilidade de uma imigração negra, sobretudo de negros norte-americanos, o que a lei anterior, mesmo se estivesse vigorando, não impediria. A forma explícita com que revelava seus objetivos foi, talvez, responsável pelos ataques que recebeu na Câmara sob a acusação de ser antirepublicano, atentar contra a igualdade e a fraternidade, ser anticatólico e desprezar a herança negra na nacionalidade. Diante disso, o projeto teve vida curta, perdendo-se nas comissões parlamentares (Câmara dos Deputados, 1921).

Uma nova versão do projeto foi apresentada pelo deputado Fidélis Reis (MG) em 1923, engenheiro agrônomo e membro da Sociedade Nacional de Agricultura (SNA). O deputado fôra, inclusive, um dos maiores defensores do projeto de Cincinato Braga quando de sua apresentação à Câmara. Sua versão, contudo, diferia do projeto anterior por preconizar, além das restrições absolutas à entrada de imigrantes negros, estímulos à imigração européia e restrições parciais à imigração amarela através de uma cota anual correspondente a $3 \%$ dos imigrantes já ingressos no País (Câmara dos Deputados, 1923:213).

Este projeto retomava e ampliava as propostas de Cincinato Braga de modo a atingir também o imigrante "amarelo", além de fazer da perspectiva racial o fundamento de toda uma política imigratória, por meio de uma série de propostas de incentivos à imigração e de política de colonização que beneficiariam os imigrantes brancos e europeus. Isto fica claro no entendimento que o próprio autor tinha de seu projeto. Segundo Fidélis Reis: 
... além das providências de outra natureza que temos em vista com o nosso projeto neste particular mais liberal e menos irritante que o dos preclaros representantes de São Paulo e Pernambuco - o que queremos é ampliar o pensamento nele contido, para tornar a proibição também extensiva, em grandes levas, ao imigrante japonês. (SNA. 1926:457)

A forma como a restrição foi proposta era claramente baseada na política imigratória americana à qual, tendo entrado em vigor em 1921, havia estabelecido, a partir de preocupações eugênicas, um regime de cotas baseado na nacionalidade dos imigrantes que já tinham entrado no País (Tucker, 1994:95).

Em sua análise, Tucker mostra que o discurso eugênico nos Estados Unidos definiu, a partir da segunda metade da década de 10 , os imigrantes como um objeto privilegiado de análise. E esta análise teve como uma de suas fontes fundamentais os estudos de psicologia que, a partir da disseminação dos testes de inteligência, concluíam pela inferioridade - quase em quadro de demência - dos imigrantes judeus, húngaros, italianos e russos em comparação com os ingleses, escoceses, alemães e escandinavos. Estes estudos produziram, assim, um quadro em que a "inteligência americana" era ameaçada pela chegada de imigrantes mentalmente inferiores e cuja solução era uma política imigratória restrita e seletiva segundo as nacionalidades, às quais eram concebidas como raças naquele sentido inicialmente referido de unidade física e mental de populações (Tucker,
1994:76-82). ${ }^{10}$

Estes eugenistas tiveram um papel importante na definição da lei americana de cotas, tendo participado, como especialistas científicos em questões de raça, da comissão do congresso americano que produziu a versão definitiva da lei em 1924. Ao descrever o depoimento de um destes eugenistas na comissão, Tucker afirma que:

(Laughin) sustentava a existência de uma 'raça americana', 'não um simples estoque' mas uma raça de pessoas brancas do norte e oeste da Europa. A questão imigratória estava assim claramente colocada. 'Nós podemos continuar a ser americanos', Laughin observou, 'recrutando e desenvolvendo nossas qualidades raciais', ou podemos continuar a ser suplantados por outros estoques raciais que são 'não-assimiláveis'. (Tucker, 1994:95)

Algumas destas formulações se fazem presente no debate do projeto do deputado mineiro que, mesmo tendo sido melhor recebido que o de seu antecessor, foi também rejeitado na década de 20. Isto significou que o impedimento à imigração negra teve de continuar sendo feito através da diplomacia. Já o tratamento aos imigrantes japoneses, pelo menos diante da lei, manteve-se inalterado ao longo da década de 20. Nos anos 30 , contudo, o "espírito" do projeto de Fidélis Reis seria resgatado na definição de cotas de imigração introduzida na constituição de 1934 (Skidmore, 1976:217).

A defesa do projeto de Fidélis Reis é particularmente útil à visualização das representações que definiram, naquele momento, os negros norte-americanos como imigrantes indesejáveis. Já na sua apresentação, Fidélis Reis definiu o episódio da tentativa de imigração dos afro-americanos como uma ameaça ao país, tratando de opor a estes o papel exercido, na "formação da nacionalidade", pelo escravo africano:

10 Cabe assinalar que Tucker mostra também a fragilidade metodológica destes testes e, sobretudo, o quanto havia de ideológico na generalização de seus resultados (Tucker, 1994:76-82). 
Quando então, pensamos, Sr. Presidente (da Câmara), na possibilidade próxima ou remota da imigração do preto americano para o Brasil é que chegamos a admitir a eventualidade da perturbação da paz no continente [...] O nosso preto africano, para aqui veio em condições muito diferentes, conosco pelejou os combates mais ásperos da formação da nacionalidade, trabalhou, sofreu e com sua dedicação ajudou-nos a criar o Brasil [...] O caso agora é absolutamente outro. Edeve constituir para nós motivo de sérias apreensões, como um perigo iminente a pesar sobre nossos destinos. (Câmara dos Deputados, 1923:147)

Tratava-se aí de opor a perturbação - relativa à violência racial - que se temia advir da imigração dos afro-americanos à contribuição dos negros africanos na construção do País. Este discurso revela uma estratégia discursiva que escamoteia a condição de escravos com que os africanos chegaram e trabalharam no país para colocar em seu lugar uma contribuição que parece quase que voluntária.

Mas afinal, que riscos eram esses?

A resposta a essa pergunta aparece de forma mais clara na argumentação que Oliveira Vianna produziu em apoio ao projeto de Fidélis Reis. Esta argumentação foi produto de uma consulta do próprio deputado mineiro àquele que, já naquele momento, era um dos principais defensores da teoria do branqueamento (Skidmore, 1976). Oliveira Vianna respondeu à consulta enfatizando o "perigo político" que representavam os afro-americanos. Segundo ele:

... estes, que nos ameaçam vir da América, se acham modelados por uma civilização superior, falando uma lingua própria e tendo um sentimento de altivez e agressividade. natural no meio em que vivem e que não possuiam os africanos que para cá vieram. em outros tempos da costa da África. Esses, pela inferioridade de sua civilização, fundiram-se com os brancos superiores: quem nos dirá que farão o mesmo os negros americanos? Mas se se conservarem 'infusiveis', neste caso teremos mais um perigo político a nos ensombrar os destinos. Se se fundirem, neste caso teremos aumentado a massa informe de mestiçagem inferior que tanto retarda o nosso progresso. (Câmara dos Deputados, 1923:380)

Esta citação revela os principais pontos do discurso acerca dos riscos da imigração dos afro-americanos. Está presente a imagem do negro norte-americano como portador de uma atitude altiva e agressiva, que tanto impressionava os políticos e intelectuais brasileiros. Em oposição a esta postura segregacionista, o negro africano é representado como consciente de sua inferioridade e, por conseguinte, predisposto à mistura, entendida como interação sexual e cultural com os "brancos superiores", onde se resguardaria aos primeiros uma posição inferior, submetida.

Esta representação dos afro-americanos definiu, assim, dois riscos fundamentais no que diz respeito ao seu desejo de imigrar. Em primeiro lugar, sua postura altiva dava margem à possibilidade de não se "fundirem'" aos "brancos superiores", insistindo por manter uma identidade própria dentro da nação.

Nossa hipótese aqui é que o principal temor em relação aos afro-americanos era o de que a negritude se destacasse da nacionalidade, ou seja, que a identidade negra escapasse ao fundo comum de uma nação concebida a partir do esquema classificatório do branqueamento, o qual pressupunha o domínio branco e a subordinação negra. A partir desta concepção, a vinda dos afro-americanos implicaria importação do "problema 
racial americano" - do "ódio entre as raças" -, pondo em risco o tipo de relação entre as raças no Brasil do qual se acreditava estar ausente a violência racial. Traduzia-se, assim, o temor de que o black nacionalism que os afro-americanos portavam pudesse ameaçar o controle que a República, pouco menos de três décadas depois da abolição, buscava consolidar sobre as possibilidades de violência negra.

Em segundo lugar, essa imigração poderia resultar em um aumento da "mestiçagem inferior", gerando em prejuízo àquela direção que a teoria do branqueamento apontava. Trata-se aqui de um temor semelhante àquele partilhado pelos eugenistas norte-americanos, e que diz respeito ao aumento do contingente das "raças inferiores" na população do País. As elites brasileiras tinham, contudo, a especificidade de, ante o elogio da mestiçagem pressuposto pela teoria do branqueamento, temer também que a mistura racial com estas "raças inferiores" levasse à geração de um mestiço "inferior" porque inverso daquele mestiço branqueado que se desejava obter por meio da imigração branca.

Esse temor, que foi intensamente mobilizado no debate da Câmara (Câmara dos Deputados, 1923:348), encontrou sua melhor expressão na análise que Afrânio Peixoto fez do projeto de Fidélis Reis, também produzida a partir de uma consulta do deputado, da qual podemos extrair as seguintes palavras:

É neste momento que a América pretende desembaraçar-se do seu núcleo de 15 milhões de negros no Brasil. Quantos séculos serão precisos para depurar-se todo esse mascavo humano? Teremos albumina bastante para refinar toda essa escória? Não bastou a Libéria, descobriram o Brasil? (Câmara dos Deputados, 1923:384)

\section{A LUTA PELOS IMIGRANTES: O INQUÉRITO SOBRE IMIGRAÇÃO E RAÇA DA SOCIEDADE NACIONAL DE AGRICULTURA (SNA)}

O debate sobre o projeto Fidélis Reis não se confinou às discussões na Câmara, tendo alcançado também entidades civis como a Sociedade Nacional de Agricultura (SNA). Esta associação produziu, em 1925, um "inquérito" cujo eixo era a discussão das propostas contidas no projeto de 1923, o qual, naquele momento, ainda se encontrava em tramitação no Congresso. Esta pesquisa foi idealizada pelo então presidente da SNA, Lira de Castro, fazendeiro paraense e engenheiro agrônomo, com o objetivo de: “...abrir um vasto inquérito em todo o País para colher a média de opiniões sobre as controvérsias do projeto" (SNA, 1926:474).

$\mathrm{O}$ inquérito foi feito através de seis mil questionários enviados a toda a diretoria da SNA, a associações rurais e comerciais, a presidentes de estado, à Academia de Medicina, à Sociedade Brasileira de Geografia, ao Instituto Histórico e Geográfico Brasileiro, a prefeitos em SP, RS, SC, RJ, GO, AL, ES, MT, MG, AM, CE, BA, PA, MA, PE, PB, $\mathrm{ES}, \mathrm{AC}$, aos principais jornais do País e a mais um conjunto de indivíduos tidos como "'autoridades" nos temas do projeto (SNA, 1926:14). Do conjunto de questionários, 166 receberam respostas provenientes de todas as regiões do País e de quase todos os estados, tendo estas sido parcialmente publicadas pela SNA num volume datado de 1926 . Responderam ao questionário membros da própria SNA, secretários estaduais de agricul- 
tura e colonização e/ou funcionários federais ligados a estes temas, e indivíduos interessados na questão.

Em que pese a pequena proporção de respostas diante dos questionários enviados, seu conteúdo revela bem o debate transcorrido no interior da entidade, uma vez que a maior parte dos questionários respondidos veio de membros da própria SNA. Porém, mais do que isso, a análise em maior detalhe destes discursos, tendo como pano de fundo a descrição mais geral de contexto que realizamos nas duas seções anteriores, nos permitirá mergulhar mais profundamente na lógica desse pensamento racial. Passemos então à análise do inquérito.

Tendo por referência o debate em torno do projeto de Fidélis Reis, o inquérito trazia perguntas que iam desde a importância da imigração, até o tipo de raça adequada à região do inquirido. Assim, a interrogação conduzida pela SNA sobre o tema da imigração seguindo a linha do projeto, foi modelada pelas representações ra-
ciais. 11

Todavia, antes de visualizar o modo como estas representações estruturaram as tomadas de posição, devemos responder algumas perguntas: Quais os interesses específicos que levaram a SNA a se envolver neste debate? E de que modo o inquérito respondia a estes interesses?

Uma primeira resposta às duas questões aponta para o fato de que o inquérito foi constituído com o objetivo de barrar as restrições propostas à imigração japonesa. Através do inquérito, a partir do projeto Fidélis Reis o debate sobre as restrições raciais à imigração é deslocado dos "negros" para os "amarelos".

Para aprofundar essa resposta é necessário delinear a estrutura da entidade e seus mecanismos de atuação. Faremos isso a partir do estudo feito por Mendonça acerca da SNA e de seu papel no interior de um movimento denominado pela autora por ruralismo (Mendonça, 1990). Agregaremos a essa análise os elementos extraídos de nossa própria pesquisa (Ramos, 1994), dos anos que vão de 1910 a 1930, no periódico A Lavoura, principal meio de divulgação da entidade.

Partindo da definição de Mendonça (1990:32), podemos identificar a SNA como instância de formalização, junto ao Estado, das demandas de determinadas frações da classe dominante agrária. Era composta por setores alijados do domínio sobre o aparato

11 As perguntas do questionário eram: (1) Julga V. Exa. necessária e útil a imigração estrangeira para o Brasil? Por que?; (2) No caso afirmativo, acha que essa imigração deva ser meramente espontânea, ou deva ser intensificada ou subvencionada? No primeiro caso, que ordem de auxílios poderão prestar os governos aos imigrantes?; (3) Pensa que essa imigração deva ser exclusivamente da raça branca? PareceThe que ela se aclimata bem em todas as regiões do País? Dá preferência a alguma nacionalidade?; (4) Qual a opinião de V. Exa. acerca da imigração amarela?; (5) Se V. Exa. aceita, em princípio, a imigração amarela, acha que ela deva ser acolhida incondicionalmente, ou opina por qualquer espécie de restrição ou de distribuição pelas zonas do País?; (6) Qual a opinião de V. Exa. acerca da imigração negra?; (7) Se V. Exa. aceita, em princípio, a imigração negra, acha que ela deva ser acolhida incondicionalmente, ou opina por qualquer espécie de restrição ou de distribuição pelas zonas do País?; (8) Que bons serviços poderão os imigrantes de qualquer das aludidas raças prestar, especialmente nas zonas em que V. Exa. emprega sua atividade?; (9) Que sugestões mais lembra V. Exa. em matéria de imigração e de braços estrangeiros para a lavoura do Brasil?; (10) Quais as idéias de V. Exa. a respeito do trabalhador nacional, sua localização, seu apego à terra, sua aptidão para a lavoura e a criação?; (1 1) Além do braço, que outros elementos de trabalho faltam às lavouras e às indústrias do nosso país, para intensificar, melhorar e baratear sua produção? 
estatal da União, que estava sob controle do complexo cafeeiro paulista. Essa definição revela dois elementos fundamentais ao entendimento da entidade: em primeiro lugar, ela foi instituída com o objetivo de canalizar e organizar as demandas de tais frações agrárias, posicionando-se a um só tempo como seu porta-voz e seu dirigente; em segundo lugar, a luta para reverter a condição periférica de tais grupos levou a entidade a desenvolver o estímulo ao desenvolvimento técnico-produtivo destes complexos agrários e o encaminhamento de ações de pressão junto ao Estado brasileiro e de propaganda junmandas de sustentação econômica. ${ }^{12}$

O diagnóstico que estas oligarquias fizeram das razões de sua posição periférica referiu-se a um "estado de atraso", originado, a um só tempo, pela precariedade técnica de uma economia que fôra por quatro séculos baseada no trabalho escravo, e pela própria solução dada a esse problema, qual seja, a abolição, vista como tendo produzido uma carência generalizada de capitais e mão-de-obra. Esse diagnóstico definiu "a falta de braços para a lavoura' como uma das preocupações fundamentais da entidade e motivo de demandas perante o Estado e aos atores políticos. Para confirmar seu diagnóstico, a SNA procurou demonstrar, com o uso de dados estatísticos, a existência de vazios demográfi-
cos no Norte e no Centro do País.

Contudo, essa falta de braços dizia respeito menos ao número concreto de habitantes destas regiões do que a um conjunto de qualificações com que se definia a figura ideal do trabalhador livre, e das quais os trabalhadores nacionais concretos pareciam distantes. E o eixo destas qualificações negativas era a ausência, por parte do trabalhador nacional, dos hábitos culturais enfeixados no termo civilização, termo com que se identificava a existência de uma disciplina para o trabalho, a posse de técnicas de produção, a
higiene na organização da casa e da produção, e o respeito às leis.

Nesse sentido, restava à SNA duas saídas básicas para a solução deste problema. A primeira delas consistiu em propostas de reforma do nacional, de modo a adequá-lo ao modelo do farmer. Nesse caso, com base em um diagnóstico do que poderíamos chamar uma "carência civilizatória", os membros da SNA constituíram como uma de suas linhas báque propiciassem a esforço para obter do Estado e dos próprios fazendeiros mecanismos escolas técnicas localizadas no próprio meion como: medidas de saneamento e higiene, e controle da circulação da mão-de-obra ruo rural, medidas de repressão à "vadiagem" ou não -, alocação de imigrantes e nacionais construção de colônias agrícolas - penais vistas como sendo necessárias à superação dos hábitos "retrógrados" que o trabalhador nacional carregava e, conseqüentemente, como mecanismo de superação de uma das principais causas do "atraso" da agricultura. Uma segunda solução consistiria no estí-

\footnotetext{
12 Outro ponto a se assinalar é que a articulação política que constituiu a SNA teve abrangência nacional. Por um lado, os membros da Sociedade provinham de uma vasta gama de regióes e complexos produti-
vos; por outro, os membros vos; por outro, os membros de sua diretoria, de um modo geral. e seus presidentes em particular, conta-
vam em seu currículo uma carreira política dos os presidentes da entidade c parte da diretoria mitia que a Sociedade combinasse a abrangência - ao Congresso Nacional. Esse histórico político peragrárias de vários estados. Esta combinação definia co conteúdo peso político da representação das elites ciedade se autodenominava (Mendonça, 1990:121).
} 
mulo à imigração européia, vista como portadora de atributos civilizatórios a serem difundidos entre os "trabalhadores nacionais". Esta função civilizadora realizar-se-ia por meio do que chamaríamos de "pedagogia do exemplo". Nesse sentido, a imigração branca foi concebida como uma das formas de resolver, a um só tempo, a falta de braços
e a falta de civilização dos braços existentes.

Entretanto, historicamente, a imigração européia concentrou-se em determinadas regiões do Sul e Sudeste do País, excluindo estados que não tinham recursos financeiros ou condições geográficas que lhes permitissem atrair o imigrante europeu. De modo que, se o imigrante europeu era o desejável, ele nem sempre era o possível. E esta diferença busca por altera no tocante à obtenção de imigrantes europeus gerou, na SNA, uma cabal, consistiu no estímulo destas alternativas, da qual o Inquérito de 1925 é testemunha vela a seguinte observação do à imigração japonesa para os estados do Norte. ${ }^{13}$ É o que rerio às respostas dos inquiridos que rejeitaramal da SNA, Heitor Beltrão, feita no comentá-

contra o amarelo. A primeira vista é o relativo às zonas que exprimem votos pró ou mais dificilmente se adapta o imigrante branco que o Norte, em cujo clima tropical desconfortos a que o amarelo se dispõe e gue o branco nem sempre supor exigem ria, com melhor insistencia a imigração amarela, cujos traços não diferemorta. quereguns sub-typos sertanistas do extremo Norte e do Nordeste. Mas não diferem muito de alNorte deu 11 votos favoráveis em 32 votantes, enquanto o Centro não foi o que ocorreu. $O$ os Sul 34 em 82. (SNA, 1926:25)

A citação revela que, a uma diferença supostamente climática entre regiões, supunha-se dever corresponder uma distribuição diferenciada das raças imigradas no território brasileiro. Tratava-se, assim, de distribuir os imigrantes no espaço de acorum país de clima temperado - do que à menos ao clima - uma vez que o Japão é os japoneses se submeteriam a "desconforesçuposica de que, racialmente inferiores, punha-se também a eficácia da mistura entos que o branco nem sempre suporta'. Sude disciplina para o trabalho com que eram os japoneses - com todos os pressupostos nistas do extremo Norte e Nordeste", imigrante japonês caberia uma tarefa braçal e raciocínio do secretário-geral da SNA, ao braço europeu não interessava enfrentar. ${ }^{14}$ civilizatória em certas regiões às quais o

Essa solução repousava, assim, num

sa: o imigrante japonês era visto num duplo raciocínio sobre a imigração japonetrabalho a que seria submetido, incluindo "menos exigente" quanto às condições de rigores climáticos onde estas tarefas seriam tanto a dureza de certas tarefas quanto os

1

Cabe recordar que naquele momento entendia-se por Norte o espaço geográfico que hoje engloba as re-
giōes Norte e Nordeste.
E esse papel civilizatório que caberia ao imigrante japonês legitimava até mesmo a mistura física com o
nacional, segundo o advogado paulista Alfredo Elis Júnior: "Dão bom cruzamento com os elementos
brasileiros, os japoneses. Dão tipos agradáveis e aparentemente eugênicos. Os que acharin feios os japo-
neses esquecem que a beleza física é relativa e os brasileiros têm, maximé (sic) no Norte, traços mongó-
licos"' (SNA, 1926:67). Para uma análise mais abrangente da imigração japonesa no Brasil, vide Saito
(1961). 
potência no cenário mundial era acompanhado de uma representação do seu povo como portador de atributos civilizatórios, tais como a disciplina ao trabalho, o hábito de pou-

\section{O DEBATE SOBRE A IMIGRAÇÃO JAPONESA}

Todavia, essa "alternativa" não era consensual nem dentro da entidade, nem dentro do debate político da época. E o que observaremos, nesta e na próxima seção, é um debate entre defensores e opositores da imigração japonesa a partir do qual fica evidente e luta simbólica envolvida na definição de uma população concreta como imigrante "de-
sejável" ou "indesejável".

Podemos observar que a oposição específica à imigração japonesa remonta, no mínimo, às primeiras experiências feitas por cafeicultores paulistas na importação deste tipo de imigrante a partir de $1906 .^{15}$

Já nesse momento, os opositores dessa imigração invocavam o exemplo norte-americano de restrição ao japonês para legitimar representações do amarelo como imigrante inassimilável. O núcleo dessa representação era a diferença entre as culturas, a suposta tendência ao isolamento no interior de seu próprio grupo e o caráter prejudicial, da mistura com o "amarelo" à evolução eugênica do tipo racial brasileiro. Evolução esta que, supostamente, vinha sendo operada por meio da importação do "sangue europeu" e sua mistura ao nacional. Esta representação gerou preocupações em torno da "proteção da raça" e mobilizou diversos segmentos das elites brasileiras, notadamente aqueles mais próximos ao discurso propriamente eugênico. ${ }^{16}$

Mesmo diante dessa oposição, a importação de braços japoneses por fazendeiros paulistas - importação que obedeceu a ciclos definidos segundo a indisponibilidade de imigrantes europeus - persistiu até o final da década de 10, a ponto de São Paulo ter concentrado, no período, cerca de $80 \%$ dos imigrantes que entraram no País. Todavia, estes ciclos se interromperam em 1922, quando o governo paulista resolveu não mais subvencionar as passagens dos imigrantes japoneses (Nogueira, 1973:228).

Esta decisão foi tributária das expectativas que cercaram o fim da Primeira Guerra Mundial. De um lado, a solução do conflito reforçou as esperanças de uma retomada do fluxo de imigrantes europeus para o Brasil, pelo menos até o começo da década; e de outro, o tema básico do conflito, a luta entre impérios, produziu uma aguda consciência dos perigos de uma nova repartição imperialista do mundo onde o território brasileiro poderia tornar-se objeto de disputa. Notadamente a segunda variável deu forte impulso aos inimigos da imigração japonesa que desencadearam, a partir de 1918, uma campanha na imprensa pedindo ao governo brasileiro restrições à entrada de trabalhadores japoneśes e condenando as anteriores iniciativas paulistas
de importação destes imigrantes.

15 Esta primeira importação, como outras que se seguiriam, explicava-se pela necessidade de fazer frente ao estrangulamento do fluxo de imigrantes europeus e pela esperança em estreitar os laços comerciais Porém, entre os eugenistas, o tema da imigração japonesa tané tas posições, vide Stepan (1990:142-143) 
Figuras de destaque do meio médico, como Miguel Couto e o então chefe do departamento de higiene de São Paulo, Arthur Neiva, acusavam os imigrantes japoneses de se aculturarem com dificuldade e de representarem o ponto de partida para uma futura colonização japonesa de terras sul-americanas (Nogueira, 1973:207). Esta campanha resultou na suspensão pelo Estado de São Paulo das subvenções a este imigrante. ${ }^{17}$

Enfim, era em meio a este quadro de acusações ao imigrante japonês, centradas nos temas da eugenia e do imperialismo, que se moviam as pretensões de determinados segmentos da SNA em promover a imigração japonesa para o Norte do País. Falamos em segmentos da SNA porque dentro da própria entidade as opiniões estavam divididas. Isto é o que nos mostra tanto o debate que se desenrolou nas páginas de A Lavoura nos meses de julho e dezembro de 1926 acerca da necessidade de imigração japonesa para a Amazônia (A Lavoura, dezembro de 1926, p.463 e junho de 1926, p.297), quanto o fato de um membro e diretor da entidade - o deputado federal por Minas Gerais, Fidélis Reis ter apresentado à Câmara o projeto que restringia a imigração japonesa, e de ter a ele se oposto, por meio da elaboração do Inquérito e das intervenções na Câmara, o presidente da entidade, senador pelo Pará, Lyra de Castro.

Para entendermos essa discordância no interior da própria entidade é necessário lembrar que a SNA se estruturava por sobre um conjunto muito diverso de complexos econômicos, cujos diferentes atrativos à imigração conformavam as posições sobre o tema. Nesse sentido, cabe lembrar que as levas de imigrantes europeus que, desde o final do Império e Primeira República, se encaminharam para o País, o fizeram tão-somente para um conjunto limitado de estados, sobretudo SP, PR, SC e RS e, em menor escala, RJ, MG, ES.

Isto implicava a existência de uma distinção quanto às expectativas diante dos diversos tipos de imigração, entre parlamentares que representavam os estados que receberam imigração européia e representantes de estados que nunca puderam contar com este tipo de imigrante. Vale dizer que a clivagem regional que separa os dois parlamentares e diretores da SNA - Lira de Castro (senador pelo Pará) e Fidélis Reis (deputado federal por Minas Gerais) - deve ser tomada como uma variável importante no entendimento da diferença de opiniões sobre a imigração japonesa.

A divisão dentro da própria SNA era, assim, expressão de uma divisão dentre os atores políticos de um modo geral, segundo os interesses regionais que representavam. E a explicação mais imediata para tal divisão consiste nas possibilidades diferenciadas destas regiões em beneficiar-se da manutenção de uma política imigratória preferencialmente centrada no imigrante europeu. Isto é, do ponto de vista dos representantes das regiões que historicamente não foram objeto de empreendimento imigratório significativo, definir o imigrante europeu como único merecedor de subsídios e de ampla liberdade de en-

17 Em 1924, Eugênio Lefévre, diretor-geral da secretaria de agricultura de São Paulo dizia: “ A imigração japonesa subvencionada foi mantida pelo governo durante alguns anos, tendo sida adotada em caráter temporário, para suprir a deficiência européia. Contudo, mesmo permanecendo as difículdades à vinda de europeus, resolveu o Estado de São Paulo em princípios de 22 não mais subvencionar a imigração japonesa. Esta resolução foi ditada pelo receio de avolumar demais no estado o estabelecimento de imigrantes que, sob os pontos de vista da formação da raça nacional, social e político, não podem nos convir. Além disso, teve o governo de atender à manifestação da opinião pública, traduzida na imprensa desta capital e do Rio de Janeiro" (apud Nogueira, 1973:209). 
trada no País implicava - pelas circunstâncias de desenvolvimento econômico e condições climáticas destas regiões - congelar a situação de inexistência de imigração para tais estados, ao mesmo tempo em que se garantia que os recursos públicos continuariam concentrados num tipo de imigração que beneficiava tão somente os mesmos estados já beneficiados.

Esta disputa em torno da definição de leis restritivas prosseguiu ao longo de toda a década de 20 , estando no centro do debate sobre a imigração de "negros" e "amarelos". Algumas destas posições tomadas no debate estão presentes nas respostas ao inquérito da SNA, e sua análise nos permitirá revelar, de maneira mais clara, a diversidade de representações constituídas em torno destes dois tipos de imigrantes, os quais são objetos de análise privilegiados para uma exposição das representações raciais e a sua lógica de operação no que diz respeito à constituição da categoria do imigrante indesejável.

\section{A POSIÇÃO DOS FAZENDEIROS SOBRE "NEGROS" E "AMARELOS"}

A rejeição tanto à imigração de "negros" como de "amarelos" esteve presente de forma acentuada, ainda que desigual nas respostas ao inquérito da SNA. No caso dos imigrantes negros, a recusa à entrada no País esteve presente em 134 das 166 respostas; já no caso do imigrante japonês, 92 respostas definiam-lhe a recusa, ou a restrição nos termos do projeto Fidélis Reis, 57 respostas lhe eram favoráveis e 14 foram omissas.

Contudo, a análise mais detida das representações presentes nas respostas nos permitiu identificar um quadro mais complexo do que simples posições de aceitação ou rejeição. Foi possível visualizar uma lógica que estrutura estas posições a partir da identificação de três categorias nativas que presidiram tanto a rejeição quanto a aceitação destes dois tipos de imigrantes (Ramos, 1994). Estas categorias são: a eugenia da raça imigrada, sua civilização e sua disponibilidade à assimilação.

Analisemos tais critérios. O primeiro critério de classificação quanto aos riscos e benefícios da imigração era o do grau de eugenia dos povos imigrados. O termo eugenia, que identificaria a disciplina científica que estuda as condições mais propícias à reprodução e melhoramento da raça humana ${ }^{18}$ (Stepan, 1990:114), foi utilizado, nestes discursos, para fazer referência ao grau de proximidade física do povo imigrado aos povos de raça branca. Nesse sentido, a imigração era considerada um instrumento de regeneração da raça, na medida que visava o aumento da proporção de sangue branco no povo brasileiro.

Como nos mostra Stepan, os pressupostos do eugenismo podiam gerar três posições: a primeira, preocupada com os meios para se obter uma procriação sadia; a segunda, com a eliminação dos fatores "disgênicos" no meio e; a terceira, que visava interditar a procriação de indivíduos ou raças - aqui no sentido biológico mais estrito que geram doenças. Todavia, na década de 20 , as duas primeiras foram predominantes, e isso por três motivos: o primeiro foi a associação entre o movimento eugenista e sanitarista; o segundo foi o predomínio das concepções lamarckistas que enfatizavam o processo de adaptação ao meio ambiente e, conseqüentemente, a necessidade de agir sobre o 
meio tanto quanto sobre o homem; c o terceiro foi o predomínio da teoria do branqueamento, à qual fundamentava uma visão positiva sobre a mistura racial envolvendo os
imigrantes brancos (Stepan, 1990:124-8).

O segundo critério consistia em avaliar o grau de civilização do povo imigrado. $O$ núcleo das representações do que era um povo civilizado continha dois elementos fundamentais: de um lado, a importância internacional do pais de origem do imigrante; de outro, a associação entre povo imigrado e a existência de uma disciplina para o trabalho, a posse de técnicas de produção, a higiene na organização da casa e o respeito às leis. Estas representações, que tinham como modelo imaginário o camponês europeu, foram usadas como critério de julgamento dos hábitos culturais, reais ou imaginários, associados aos demais imigrantes. A partir daí, todas as práticas culturais que se afastassem deste modelo eram tomadas como índice da ausência de civilização. Isto fazia do imigrante branco o principal instrumento de difusão, entre os "trabalhadores nacionais", de uma civilização cujos conteúdos eram a disciplina, a produtividade, a higiene, o respeito às
leis e à propriedade.

Um terceiro e fundamental critério de avaliação das possibilidades de imigração era a propensão dos povos imigrados em se deixarem assimilar pelo "meio" brasileiro. Nas representações das elites republicanas, conformadas pela teoria do branqueamento, a imigração branca, com todos os elementos positivos físicos e mentais que poderia trazer, carregava como função básica a de se misturar ao nacional, de tal forma que a resistência a esta mistura implicava a própria negação de seu papel fundamental.

A assimilação como critério seletivo articula-se ainda ao temor de que, mantida a unidade cultural e física do imigrante em regiões fracamente ocupadas pelo elemento nacional, essa unidade étnica desse origem, seja a uma ocupação imperialista, seja a reivindicações pela constituição de comunidades políticas próprias. Era o temor de que grados, a partir da manutenção de uma unidade física e cultural entre os povos imidefiniram um elenco de medidas visando a dissolução dessa suposta unida preocupações tural do imigrante. 19 missolução dessa suposta unidade física e cul-

O que é particularmente interessante em tais critérios, sobretudo os de eugenia e civilização, é que eles corporificam aquela concepção de raça como um cruzamento entre o físico e o cultural/histórico. Vale dizer que tomar uma posição sobre o caráter desejável ou indesejável de uma raça de imigrantes implicava avaliar sua contribuição biológica e cultural à constituição do "povo brasileiro" e, também, avaliar a disponibilidade da raça imigrada a oferecer tais contribuições ao povo brasileiro, se deixando assimilar. Este jogo de critérios era particularmente útil a uma negociação simbólica onde alguns critérios poderiam ser colocados em primeiro plano em detrimento de outros.

Nesse sentido, para os defensores da imigração japonesa tratava-se de tornar vitoriosa a representação do japonês como um imigrante oriundo de uma civilização bastante

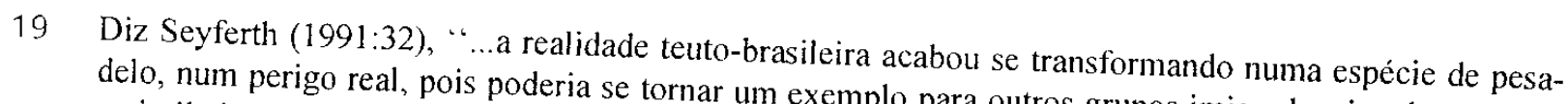
assimilados. Nas quatro décadas que antecederam a campanha outros grupos imigrados, igualmente não de Estados dentro do Estado - derivado da forma desastrosa com que foi realizada o perigo da formação - foi o argumento empregado por segmentos da elite brasileira e pelo próprio Estado colonização do Sul assimilação forçada". 
desenvolvida e portador de grande disponibilidade à assimilação, o que faria dele, em que pese ser visto como eugenicamente inferior, um imigrante altamente recomendável. Nestes argumentos, a positividade de sua civilização foi construída por meio de uma ênfase na sua disciplina ao trabalho. E a defesa de sua predisposição a se deixar assimilar argumentação obviamente mais difícil que a primeira - se deu por meio da representação do "japonês" como um tipo ordeiro e respeitador das leis e das autoridades. Esse padrão de defesa expressa-se de modo cristalino na posição adotada pelo Prefeito da cidade de Antonina, Paraná, João Ribeiro da Fonseca:

Embora o ideal seja a arianização de nossa raça, o japonês é o tipo do trabalhador ideal, pelo espirito de ordem, de iniciativa, de capacidade e de disciplina. Não acredito no chamado 'perigo amarelo' dadas as qualidades de ordem e respeito do japonês, que acatam as leis e as autoridades locais, jamais as incomodando, de modo que as estatisticas policiais só raramente registram um japonês envolvido, mesmo em simples casos correcionais. Ele é assimilàvel se não o deixamos isolado. Concorda em que do ponto de vista estético, seja elemento que não satisfaça: mas suas grandes qualidades sobrelevam esse defeito e ele nos dá aquilo de que mais necessitamos: o esforço produtivo admirável. (SN $\Lambda, 1926: 198)$

Essa citação resume alguns dos principais argumentos do discurso pró-japoneses que pudemos encontrar nas respostas. Assim, ante a imagem do amarelo oriundo de uma civilização decadente, o inquirido opõe a do trabalhador organizado, com espírito de iniciativa, disciplinado e capaz. $\grave{\Lambda}$ crença no "perigo amarelo" - expressão que identifica os temores acerca de possíveis pretensões imperialistas sobre o Brasil - o autor contrapõe a representação de um tipo ordeiro, de tal modo adaptado à autoridade, tanto a do Estado Nacional Brasileiro na forma de suas leis quanto a do patrão no trabalho da lavoura, que não se lhe registram prisões e sequer inquéritos. E ao discurso que propõe o melhoramento racial pela imigração exclusiva do sangue branco - o "ideal de arianização", do qual compartilhava o autor - pouco havia a fazer, senão colocar o critério eugênico em segundo plano, enfatizando os demais. Afinal, nem tudo que se deseja se pode obter.

No sentido contrário, os mais radicais opositores da imigração japonesa representavam-na como marcada pela ausência ou decadência de civilização, e como portadora de costumes, língua e comportamentos que impediam a mistura com o nacional. Esse era o tipo de argumento que havia sido mobilizado já na década de 60 do século XIX, quando da possibilidade da imigração chinesa para São Paulo (Azevedo, 1987). Nessas representações, o chin era fruto de uma civilização decadente, portador de hábitos viciados, inútil ao trabalho e infenso à assimilação.

Nas respostas ao inquérito do SNA estas representações sobre o chin são, algumas vezes, reproduzidas em relação à imigração japonesa. E nessa reprodução é que se produziram as visões mais negativas sobre o japonês. Foi assim que o professor Benedicto Edelberto de Goés, de Coary, Amazonas, quando indagado a respeito afirmou ser “ "... contrário à imigração amarela porque os indivíduos dessa raça são indolentes e dados ao vício de inebriantes" (SNA, 1926:99).

No mesmo sentido, porém de forma mais sofisticada, o deputado federal por São Paulo e relator do projeto de Fidélis Reis, João de Faria, afirmava:

Imigrante caro, devido à distância de seu país natal, o japonês não agradou o fazendeiro paulista. A sua língua nos é incompreensivel, os costumes são muito diferen- 
tes dos nossos, com um aspecto fisico pouco atraente, dotado de uma moral que a nosso ver, é estranhável e se caracteriza pela falta de cumprimento de seus contratos, o colono japonês, em regra, quando recebe o pagamento, deserta em massa da fazenda durante a noite. O fazendeiro desconfiou logo desse colono, porque ele não se arranjava convenientemente a sua casa, dormia no chão, com agasalhos de infima ordem [...] e o banho era tomado em comum, entre homens e mulheres, atirando água uns sobre os outros, de modo que a casa já sem higiene, ficava em petição de miséria. (SNA. 1926:462)

Temos aí o tema da inassimilação - presente na afirmação de que tais imigrantes possuem uma moral marcada pelo "não cumprimento de seus contratos", o que caracteriza uma "inadaptação" à própria lógica que preside a importação de imigrantes pela lavoura cafeeira - da eugenia, o "aspecto físico pouco atraente", e da civilização, a ausência de hábitos de higiene e de conforto -, o que foi descrito nas palavras de um dos inquiridos como "ausência de hábitos de raça refinada" (SNA, 1926:87). Estes temas permitiram aos adversários da imigração japonesa produzir, de tal imigrante, uma visão triplamente negativa, tomando-o como o exato inverso do imigrante ideal.

Um outro tipo de crítica recaiu sobre o imigrante japonês, tendo atingido também a imigração dos afro-americanos. O eixo desta crítica era a imagem de um imigrante portador, a um só tempo, de inferioridade racial, de um alto grau civilizatório e de uma rejeição à assimilação. A combinação específica entre assimilação e civilização foi a base sobre a qual estruturaram-se os temores de que os imigrantes estivessem vinculados a práticas imperialistas ou pudessem, no futuro, nutrir desejos separatistas. Tais temores derivavam-se da crença de que um alto grau de civilização e cultura, quando associado a práticas isolacionistas, tem por efeito reforçar as identidades étnicas das populações imigradas, reforço esse que é associado ao imperialismo e ao separatismo na medida da vigência daquelas concepções que derivam os Estados Nacionais de uma prévia unidade física e cultural dos povos que lhes formam. ${ }^{20}$

Esta representação emprestaria um sentido especial ao critério da eugenia. Pois, além do perigo político que representavam - por ameaçar a unidade e soberania do Estado Nacional -, os japoneses eram vistos como ameaça à unidade cultural e racial da qual deveria emergir o "tipo único brasileiro". Na definição de Darcy Azambuja, lavrador no Rio Grande do Sul:

A raça amarela tem constituição mental, tradições, costumes, tendências e aspirações tão arraigadas e diferentes das nossas que nunca se integrariam na massa da nacionalidade brasileira e, antes, prolongariam, indefinidamente, o caos etnológico em que nos debatemos. A colonização amarela formaria aqui, o quisto social que formam os negros na América do Norte. (SNA. 1926:124)

Além dos "japoneses", os imigrantes negros vindos da América do Norte se enquadram nesta classificação e são objeto de uma rejeição ainda mais profunda e violenta. Eles são o alvo da resposta do General Moreira Guimarães, presidente da Sociedade de Geografia do Rio de Janeiro, que responde ao inquérito da SNA afirmando: 
Deve ser cauteloso o processo seletivo de modo que se evite a entrada de qualquer grupo étnico de raça negra consubstanciando uma mentalidade perturbadora dos interesses nacionais e que não se altere profundamente o equilibrio dinâmico das percentagens dos componentes atuais da futura raça brasileira. (SNA. 1926:278)

A resposta acima expõe duas faces desse temor: a idéia de que os negros norteamericanos trariam um tipo especial de inassimilação, que consistia "ódio de raças", e que sua vinda poderia alterar a correlação de forças expressa na idéia de equilíbrio percentual dos componentes da raça brasileira. O temor de que se atualizassem no Brasil conflitos raciais como aqueles vividos nos E.U.A. aparece também na resposta do médico e Diretor Geral do Serviço de Estatística do Ministério de Agricultura Indústria e Comércio, José Luiz Sayão de Bulhões Carvalho:

É contrário à imigração de negros porque viria a perturbar o processo de fusão das raças que aqui se vai operando. Seria andar para trás e transplantar para o Brasil o problema racial que os E.U.A., apesar de seu espírito prático não conseguiram até hoje resolver. (SNA. 1926:214)

Ou ainda, nas palavras do já mencionado Antônio Americano do Brasil:

Já não teríamos para a lavoura as gentes simples, que foram os primitivos africanos da escravatura, facilmente identificando-se com a terra. Os negros de hoje viriam dos Estados Unidos, de São Salvador, de Barbados, elementos cheios de defeitos, carregando o ódio ao branco que os tem perseguido, possuindo apurados vícios que não tiveram os antigos escravos. (SNA.1926:73)

Estas citações definem apenas uma parcela dos temores em relação à imigração negra, notadamente a preocupação com a guerra civil que atingiu os E.U.A. e com as lutas anti-escravistas ocorridas em Barbados e São Salvador. As respostas revelam ainda o temor que esse ódio racial, enquanto padrão de relação com a hierarquia racial, pudesse servir de exemplo aos outros contingentes negros que compunham a população brasileira, produzindo uma ruptura, a um só tempo, da hierarquia racial e do processo de mistura sobre o qual se definia a unidade política da Nação. Tal temor se expressa na seguinte declaração do professor e Presidente do Círculo do Magistério Noturno Municipal no Rio de Janeiro, Gabriel Bandeira de Faria:

Os negros são inferiores aos amarelos. Fiquemos apenas com os nossos homens de cor, os quais são honestos, dignos, honrados, ótimos cidadãos, magnificos trabalhadores e parte integrante da nossa nacionalidade. Não procuremos confundi-los nem corrompé-los com os produtos estranhos e maléficos, perniciosos, exóticos, originários da Africa ou mesmo dos Estados Unidos. (SNA. 1926:157)

Trata-se aqui de opor o "ódio racial" dos negros norte-americanos à perfeita integração do negro brasileiro à nacionalidade, como faz o secretário-geral da SNA, Heitor Beltrão:

Aliás, conforme se pode ver dos resumos contidos nas fichas individuais, nem todos são fundamentalmente adversos à raça negra; quase todos elogiam os brasileiros desta raça e exprimem sua gratidão aos serviços por esses prestados à pátria, expressando, outrossim, frequiente alusão à integração da mesma em nossa nacionalidade, o que faz desaparecer aqui o problema, que tão visceralmente preocupa os Estados Unidos da América do Norte. (SNA, 1926:31) 
Nas representações sobre o imigrante negro esse "problema racial" se tornaria ainda máis dramático na medida em que sua vinda aumentaria o contingente negro no Brasil, e a associação entre um padrão de comportamento agressivo e um aumento da população negra produziria o desequilíbrio da hierarquia racial vigente. Daí o já citado Antonio Carlos Simões da Silva declarar:

Não aceito a imigração negra porque enquanto o Brasil tiver em seu seio o número de representantes dessa raça. que ascende aos demais nele existentes, parece que seria desequilibrar a bela harmonia reinante entre as mesmas, cogitar-se na entrada de individuos da mesma raça máxime em grandes grupamentos, o que viria como tempo e seu peculiar de proliferação, a assenhorar-se de todo o país, em franco detrimento das demais. Mesmo em favor do elemento negro do Brasil não deve ser facilitada essa imigração, pois viriam imigrantes de religião diferente das dos negros do Brasil, que são católicos fervorosos, e sem o entusiasmo patriótico que o negro tem aqui, pelo Brasil. Ademais o negro norte-americano traria o odio contra o Branco e contra o amarelo, aqui felizmente desconhecido. (SNA. 1926:79)

$\mathrm{Na}$ medida em que o autor não considera que a vinda de japoneses e europeus em massa também pudesse perturbar a "bela harmonia" entre as raças, fica claro que a "harmonia" remete não ao número de indivíduos que as raças possuíam na população global, mas a uma dada correlação de forças em que a população branca deveria predominar. A idéia de uma "harmonia racial" remetia, assim, a um afastamento das possibilidades de conflito, de modo que a mistura racial deveria ser conduzida dentro de uma determinada hierarquia em que prevaleceria a raça branca. Em resumo, o risco da imigração de negros norte-americanos, para além de sua suposta inferioridade racial, consistia na possibilidade de que não se fundissem, seja fisicamente ao trabalhador nacional, seja simbolicamente à cultura brasileira.

\section{RAÇA E IMIGRAÇÃO NA PRIMEIRA REPÚBLICA: A BUSCA DO PONTO DA MISTURA}

Até aqui procuramos evidenciar as representações constitutivas da categoria do imigrante indesejável. Todavia, o que nos parece relevante no caminho que trilhamos foi revelar a lógica que organiza este pensamento racial como um conjunto articulado de representações, às quais definem tanto os imigrantes desejáveis quanto os indesejáveis, posto que são lados da mesma moeda. Daí, o que tentaremos fazer nesta conclusão é apontar o eixo sobre o qual se construiu esta lógica racial entre intelectuais e políticos republicanos nos anos 20 .

Nossa hipótese básica é que eixo da articulação entre raça e imigração na Primeira República residiu na função atribuída ao imigrante de fornecer contribuições a uma "mistura" física e cultural da qual resultaria um "tipo brasileiro" único e superior. Este eixo foi o responsável pelos esforços em controlar a imigração, tornando-a instrumento de construção da "mistura" homogênea e superior que deveria ser o povo brasileiro.

$\mathrm{Na}$ base dessas representações estava o ideal de aumento do contingente de sangue branco na população brasileira. Este mesmo ideal orientara a política imigratória dos governos imperiais. Naquele período buscou-se obter uma inversão da pirâmide populacional, cuidando que houvessem mais brancos que negros no País, por meio da adição dos 
imigrantes europeus à população branca já existente. Mas, a partir dos anos 80 do século passado, a esse ideal somou-se uma preocupação de que os imigrantes brancos se dispusessem à miscigenação e à assimilação cultural. ${ }^{21}$ A partir daí, a prática ou não da miscigenação, bem como os tipos que ela viria a produzir, e a disponibilidade à assimilação funcionaram como eixos de referência de estímulo e de crítica de todos os empreendimentos migratórios, até mesmo dos. "brancos". Sílvio Romero, por exemplo, tendo por referência o imperativo da miscigenação e da assimilação como requisitos para a construção de uma Nação branca, formulou críticas ao "enquistamento alemão" no Sul do País, preocupado com o fato de colonos imigrados não se casarem e não aprenderem a língua portuguesa (Seyferth, 1991).

Uma das explicações da ênfase sobre a miscigenação diz respeito ao fato de que a constituição do Estado Republicano como Estado Nacional passou, necessariamente, pela elaboração de um conjunto de representações acerca da identidade nacional brasileira. E muitas das imagens de Nação fabricadas ao longo das primeiras décadas da República conceberam a unidade nacional como problema relativo à produção de um povo brasileiro, à produção de uma unidade racial em meio à diversidade de populações que ocupam o território. 22

Contudo, se por um lado a idéia de homogeneidade racial como base da Nação definiu a miscigenação como meta fundamental da imigração, por outro tal prática foi concebida como devendo ser orientada pelos pressupostos de desigualdade contidos nas teorias raciais. Essa combinação de miscigenação e desigualdade racial - ou, em outros termos, de mistura e hierarquia entre raças - foi responsável pela definição de um papel privilegiado para os povos de raça branca.

Assim, ao mesmo tempo que a mistura era um eixo fundamental das representações sobre o imigrante, os vários componentes possíveis dessa mistura nunca foram tomados como equivalentes entre si. Ao contrário, foram classificados nos termos de uma nítida hierarquia racial que definia desde a plena positividade de determinados povos até a extrema negatividade de outros. Essa classificação não recomendava quaisquer

21 Seyferth (1991:11) assinala o final do século XIX como o momento em que o Estado brasileiro muda de posição em relação às populações imigradas, enfatizando menos o papel colonizador dos povos brancos do que sua disponibilidade à assimilação, por conta do temor dos chamados "quistos étnicos". Segundo a autora, quando entra em cena a tese do branqueamento - e o seu corolário: a idéia de miscigenação -, os alemães cedem lugar aos povos latinos como imigrantes brancos preferenciais. Os alemães considerados inassimiláveis passam também a ser vistos como um "perigo" para a unidade nacional.

22 Essa ênfase na produção de um povo esteve diretamente ligada à passagem da Monarquia à República, quando se tentou definir a existência de um povo brasileiro - cuja expressão seria o mestiço - como eixo simbólico da unidade nacional. Até então, este eixo cra definido pela figura do imperador. Esse deslocamento encontra similar na história européia e foi assim descrito por Michel Foucault, para o caso da França, em entrevista ao periódico Quel Corps: "Numa sociedade como a do século XVII, o corpo do rei não era uma metáfora, mas uma realidade politica: sua presença física era necessária ao funcionamento da monarquia... [A república "una e indivisível" - ISR] é uma fórmula imposta contra os girondinos, contra a idéia de federalismo à americana. Não há um corpo da República. Em compensação, é o corpo da sociedade que se torna, no decorrer do século XIX, o novo princípio. É esse corpo que será preciso proteger, de um modo quase médico: em lugar dos rituais através dos quais se restaurava a integridade do corpo do monarca, serão aplicadas receitas terapêuticas, como a eliminação dos doentes, o controle dos contagiosos, a exclusão dos delinquientes. A eliminação pelo suplício é. assim, substituída pelos métodos de assepsia: a criminologia, a eugenia, a exclusão dos degenerados..." (Foucault, 1986:145). 
misturas, mas tão-somente aquelas que pudessem representar a melhoria biológica e a civilização do trabalhador nativo. E mesmo para a imigração branca postulava-se uma hierarquia a recomendar diferentes combinações segundo o povo imigrado e a região onde seria instalado.

, Por fim, os mecanismos de seleção dos imigrantes tiveram também um papel de reforço e reprodução da hierarquia entre populações, característica da sociedade brasileira.

Estes mecanismos de seleção, que propiciavam o aumento da população branca, tinham por objetivo reduzir os riscos de um questionamento da ordem racial vigente por meio da violência dos não brancos. Mas, para que este resultado pudesse ser alcançado, era necessário que os imigrantes brancos não representassem, eles mesmos, uma ameaça à "'ordem constituída". Daí que os mecanismos de seleção levassem em conta, além da cor da pele, a necessidade de se obter os mais assimiláveis entre os brancos e, quando não fosse possível evitar, os mais "dóceis" entre as "raças inferiores". Tratava-se, sobretudo, de esconjurar o risco máximo de não brancos indóceis, inassimiláveis e que pusessem em questão a hierarquia racial - o que era o caso da representação que recaía sobre os afro-americanos.

\section{REFERÊNCIAS BIBLIOGRÁFICAS}

AURÉLIO ELETRÔNICO, 1994. (C. A. Lacerda \& P. Geiger, orgs.). São Paulo: Nova Fronteira. AZEVEDO, C. M., 1987. Onda Negra, Medo Branco. Rio de Janeiro: Paz e Terra.

CARELI, M., 1985. Carcamanos e Comendadores. São Paulo: Ática.

CÂMARA DOS DEPUTADOS, 1921. Anais da Câmara. Vol. 10. Rio de Janeiro: Imprensa Nacional.

CÂMARA DOS DEPUTADOS, 1923. Anais da Câmara. Vol. 14. Rio de Janeiro: Imprensa Nacional.

FOUCAULT, M., 1986. Microfisica do Poder. Rio de Janeiro: Graal.

HALL, M., 1969. Origins of Mass Imigration in Brasil, 1871-1914. New York: Columbia University Press.

HELLWIG, D. J., 1988. A new frontier in a racial paradise: Robert S. Abbotts Brazilian dream. Luso-Brasilian Review, 25:59-67.

HOBSBA WM, E., 1988. A Era dos Impérios. Rio de Janeiro: Paz e Terra.

LAPLANTINE, F., 1991. Aprender Antropologia. Rio de Janeiro: Brasiliense.

LESSER, J., 1994. Legislação imigratória e dissimulação racista no Brasil (1920-1934). Arché Ano III, no 8. Rio de Janeiro: Faculdades Cândido Mendes.

LESSER, J., 1995. O Brasil e a Questão Judaica. Rio de Janeiro: Imago.

MAIO, M. C., 1995. O mito judaico em casa grande e senzala. Arché, ano IV, no 10. Rio de Janeiro: Faculdades Cândido Mendes.

MEADE, T. \& PÍRIO, G. A., 1988. In search of the Afro-American 'eldorado': attempts by North American blacks to enter Brazil in the 1920s. Luso-Brasilian Review, 25:85-108. 
MENDONÇA, S., 1990. O Ruralismo. Tese de Doutoramento. São Paulo: Universidade de São Paulo.

NOGUEIRA, A. R., 1973. A Imigração Japonesa para a Lavoura Cafeeira (1908-1922). São Paulo: Instituto de Estudos Brasileiros.

ORTIZ, R., 1985. Cultura e Identidade Nacional Brasileira. Rio de Janeiro: Brasiliense.

RAMOS, J. de S., 1994. O Ponto da Mistura: Raça, Imigração e Nação em um Debate da Década de 20. Dissertação de Mestrado. Rio de Janeiro: Museu Nacional, Universidade Federal do Rio de Janeiro.

SAITO, H., 1961. O Japonês no Brasil. São Paulo: Ed. Sociologia e Política.

SCHWARCZ, L. M., 1993. O Espetáculo das Raças. São Paulo: Companhia das Letras.

SEYFERTH, G., 1991. Os paradoxos da miscigenação. Rio de Janeiro: Museu Nacional. (mimeo.)

SNA (SOCIEDADE NACIONAL DE AGRICULTURA), 1926. Inquérito Sobre Imigração. Rio de Janeiro: Ed. Irmãos Versini.

STEPAN, N., 1990. Eugenics in Brazil, 1917-1940. In: The Wellborn Science (M. Adams, org.), pp. 110-152. New York \& Oxford: Oxford University Press.

SKIDMORE, T., 1976. O Preto no Branco. Rio de Janeiro: Paz e Terra.

TUCKER, W., 1994. The Science and Politics of Racial Research. Urbana and Chicago: University of Ilinois Press.

WILLENS, E., 1980. A Aculturação dos Alemães no Brasil. São Paulo: Cia. Ed. Nacional.

\section{PERIÓDICOS}

A Lavoura. 1910-1930 


\section{Parte II}

\section{A REINVENÇ̃̃O DA RAÇA NAS DÉCADAS DE 30 E 40}




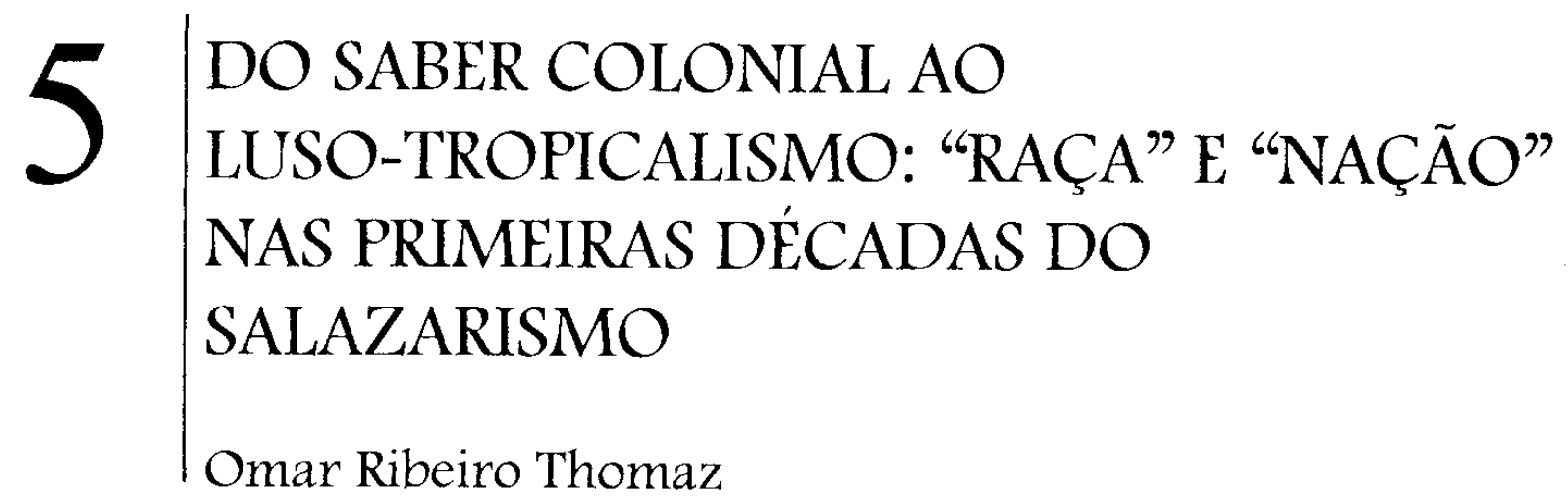

\section{INTRODUÇÃO}

Em setembro de 1934, as primeiras páginas dos jornais portugueses noticiaram a morte de Papé, "o preto atlético dos Bijagóz", 1 que, desde junho daquele ano, encontrava-se alojado, junto aos "indígenas" das demais colônias portuguesas da África, do Oriente e da Oceania, em um dos pavilhões da $1^{\text {a }}$ Exposição Colonial Portuguesa, realizada na cidade do Porto. Representante de uma das "raças do Império", seu enterro levou às ruas uma grande multidão.

As mulheres, sobretudo, sentiam, com uma ternura funda, portuguesissima, a morte daquele homem que não tinha história, daquele homem que não era da sua cor, que não era da sua raça.

Estavam presentes representantes dos nativos de quase todas as colonias. E todos mostravam, nas fisionomias, na atitude, um respeito profundo, em face do português negro que morrera subitamente (...).

(...)

O enterro de Papé foi outra página de grandeza.

(...)

Em nome de Mamadu-Sissé, seu filho Abdulai disse, em duas palavras, que os portugueses nativos da Guiné não esqueciam a forma carinhosa, fraternal, exemplar por que os portugueses da Metrópole, os brancos que a mesma bandeira verde e vermelha cobre, haviam dado sepultura ao pobre Papé.

(..)

O sol dardejava sobre as cabeças descobertas. Da multidão, agora em debandada lenta, subia o clamor vago da comiseração. Coitadinho! É só um garotito que rabiava por entre o povo, ansioso do espetáculo, pos a nota da irreverência naquele ato solene, simples e tocante, grulhando: Nem parecia o enterro dum preto!

E não. Em verdade, fora o enterro dum português. (Comércio do Porto)

1 Arquipélago africano da costa da Guiné-Bissau, na época, Guiné "Portuguesa". Habitado majoritariamente pelo grupo étnico bijagó. 
Neste pequeno texto do Comércio do Porto - o mais importante matutino do norte de Portugal - afirma-se a comoção que abateu a população que há meses participava dos eventos promovidos pela Exposição Colonial. No enterro, segundo o artigo, manifestava-se a alma portuguesa: o choro pela morte de um homem "que não tinha história", um "preto", um indivíduo de "outra raça". Tratava-se, no entanto, do enterro de um "preto" unido à multidão branca metropolitana - e aos demais "indígenas" vindos das mais diferentes partes do Império - por uma mesma nacionalidade, por uma mesma bandeira. Um individuo "sem história" - ou que entra para a história pela mão e graça de Portugal. ${ }^{2}$

Proveniente da Guiné, sua especificidade se expressava, inclusive, na legislação lusitana: o Ato Colonial de 1933 estabelecia diferenças de direitos e deveres entre os nascidos na metrópole e colonos, os "assimilados" e os "indigenas". 3 No entanto, o artigo do Comércio do Porto, assim como tantos outros dedicados às colônias por ocasião da $1^{\underline{a}}$ Exposição Colonial Portuguesa, não deixa dúvidas: brancos ou pretos, todos são portugueses.

Esta concepção não deixa de colocar problemas quando estamos diante de uma "situação colonial" (Balandier, 1993) e, sobretudo, quando o acesso à cidadania está vinculado à origem ou ao grau de "assimilação". As diferentes "raças" - assim eram classificadas as muitas sociedades que habitavam o então espaço sob dominação portuguesa - estavam vinculadas a uma mesma "nacionalidade", que parecia poder comportar a diversidade cultural observada no território imperial. Como transformar uma entidade política hierárquica - o Império - na representação homogeneizadora que supõe a idéia de "nação"? É sobre a concepção de "nação" a partir dos discursos produzidos em torno do Império, das suas gentes, da sua história e do seu destino, que se debruça este texto.

Dar conta da totalidade dos discursos que têm como objeto as terras e as gentes do Império é uma tarefa que extrapola em muito os meus objetivos. As décadas de 30 e 40 em Portugal vieram marcadas por uma produção intelectual e propagandística intensa no que se refere às colônias africanas e orientais. Foram promovidas pelo Estado - em aliança com setores empresariais e com a Igreja grandes exposições coloniais que, se chegam tarde no Extremo-Ocidente europeu, calaram fundo numa opinião pública fortemente sensibilizada com relação aos

Em outro trabalho, procuro trabalhar com as noções de "tempo" e de "história" presentes na Exposição Colonial do Porto de 1934 e na Exposição do Mundo Português de 1940. Nas exposições, os "indígenas" das diferentes colônias não são apenas representantes dos estágios da evolução humana - algo presente das exposições coloniais realizadas em outras metrópoles - mas são, sobretudo, testemunha e retrato de distintos momentos da própria "história" de Portugal (Thomaz, 1994; Lichtenthaler \& Thomaz, 1996).

3 Não fará parte deste texto uma análise mais detida em torno da legislação ultramarina portuguesa, análise ainda $\mathrm{cm}$ andamento. É importante lembrar, no entanto, que o advento do Estado Novo em Portugal representou transformações radicais na legislação ultramarina predominantemente liberal que caracterizara as últimas décadas da monarquia e as primeiras da república. O Estado Novo scrá o propulsor de um legislação que transportará a "diferença" entre as distintas populações do Império para o texto legal. O Ato Colonial institui a "tutela" no que se refere às populações "indígenas" de São Tomé e Príncipe, Guiné, Angola, Moçambique e Timor. Possuíam um estatuto especial os naturais de Cabo Verde, do Estado da Índia Portuguesa e de Macau. Para mais informações, vide Agência Geral das Colônias (1947). Sobre a legislação colonial portuguesa e scus impasses ao longo do século XX, vide Bender (1980). 
destinos do Império. ${ }^{4}$ Por sua vez, intelectuais ligados a diferentes instituições encarregadas de refletir sobre o Império e produzir os seus quadros admininistrativos e burocráticos obtiveram apoio do Estado na organização de encontros e congressos que tinham as colônias como objeto. ${ }^{5}$ Por fim, o debate intelectual e político em torno das colônias ocupou - sob a vigilância do regime autoritário de Salazar - as páginas dos mais importantes periódicos e a ele foram dedicadas inúmeras publicações.

Deter-me-ei, nos limites deste texto, nas Conferências de Alta Cultura Colonial de 1936, um dos encontros promovidos pelo Estado e por instituições ligadas diretamente à produção de um "saber colonial" que procurava discutir a história, a realidade presente e o destino do Império (Agência Geral das Colônias, 1936). As Conferências de 1936 foram apresentadas na Sociedade de Geografia de Lisboa, uma das mais antigas e afamadas instituições portuguesas que procurava dar conta do espaço imperial. A escolha deste evento não foi aleatória: por um lado, reuniu grandes personalidades colonialistas do período e a classe política do Estado Novo; por outro, e este aspecto é fundamental, se propôs a ser um encontro de "Alta Cultura Colonial", longe portanto dos fins pragmáticos que moveram outros eventos da mesma natureza. A "nação" se encontra aqui, como veremos, no centro das preocupações destes intelectuais.

As Conferências de Alta Cultura nos oferecem a oportunidade de apreender uma das interpretações do Império Colonial Português: a daqueles indivíduos ligados a instituições comprometidas com o projeto colonial do Estado Novo. Esta interpretação se viu parcialmente reproduzida nas Exposições Coloniais e nas páginas da imprensa. Não pretendo com isso sugerir a existência de um "consenso": na Península ou nas colônias outras vozes emergiam, ora radicalizando propostas autoritárias, ora se rebelando contra 0 sistema colonial. Entre elas não podemos esquecer a resistência dos nativos dos territórios sob domínio português, ${ }^{6}$ como tampouco menosprezar a censura que o regime salazarista impunha à imprensa. Longe, portanto, de propor a existência de um discurso "hegemônico", o objetivo aqui é discutir uma face pouco conhecida da história intelectual portuguesa. ${ }^{7}$

Por fim, na última parte do texto, retomo a fase luso-tropical de Gilberto Freyre pois, como veremos, a universalização de uma teoria inicialmente restrita ao espaço e tempo brasileiros se deu a partir de um diálogo implícito de Freyre com a intelectualidade colonialista das primeiras décadas do salazarismo. O Brasil - que já emergia como re-

4 Em 1934 foi realizada a I Exposição Colonial Portuguesa. A ela se seguiram a Exposição Histórica da Ocupação. realizada em Lisboa cm 1937 e a grandiosa Exposição do Mundo português, também organizada na capital lusa. Esta última contava com inúmeros pavilhões, entre os quais aqueles dedicados unicamente à temática colonial. Sobre as exposições em Portugal, vide França (1985), Portela (1987), Saial (1991), Rosas (1994), Thomaz (1994) e Lichtenthaler \& Thomaz (1996). Sobre as exposições coloniais realizadas em outras metrópoles, vide Ageron (1984), Bancel (1993), Benedict (1993), Corbey (1993), Girardet (1972), Hoider \& Pierre (1991), Stocking (1987) e Street (1992).

5 Foram realizados, entre outros. o Congresso Colonial, por ocasião da Exposição do Porto em 1934, as Conferências de Alta Cultura Colonial, em 1936, e os Congressos do Mundo Português, em 1940.

6 Sobre a resistência dos povos africanos na história recente do colonialismo português na África vide, entre outros, os trabalhos de Pélissier (1979, 1986, 1987, 1989).

7 Até onde eu sei, não são muitos os trabalhos existentes sobre as instituições colonialistas portuguesas ou sobre as relações entre os intelectuais e o projeto colonial. Destaca-se o trabalho de Gallo (1988). Vide também Pélissier $(1979,1983)$ e Moutinho (1980). 
ferência nas Conferências ou na Exposição do Mundo Português - se transformará a partir da década de 50 em uma imagem do futuro da colonização portuguesa em territórios tropicais.

Antigas representações da velha pátria lusa são reatualizadas seja nas exposições ou nas falas de intelectuais. A morte e o enterro de Papé ganham, neste contexto, outros significados: um evento singular que pôs em marcha e (re)atualizou representações sobre o Império português, sobre a nação, o seu passado e o seu futuro. Para isso o trouxeram da Guiné, e mesmo a sua morte, servia para estes fins. ${ }^{8}$

\section{O SABER COLONIAL}

Na abertura das Conferências de Alta Cultura Colonial, promovidas pelo Ministério das Colônias na Academia de Ciências de Lisboa entre março e abril de 1936, o então ministro das colônias, Francisco José Vieira de Carvalho, afirma a importância dos homens de ciência no projeto de expansão colonial portuguesa no mundo:

Sem a colaboração intima, fecunda, dos homens de pensamento e dos homens de ação, sem a projeção da idéia sobre a realidade concreta, Portugal nunca teria sequer iniciado a sua ação colonial, apoteose de um povo heróico, orgulho desta $\mathrm{Na}$ ção nimbada de glória, cujo fruto magnífico são os mundos que deu ao Mundo.

Foi uma conjunção da ciência com a ação, do pensamento com a combatividade, que tornou possivel toda a nossa esplendorosa obra colonial. (Agência Geral das Colônias, 1936:13)

A expansão colonial só foi possível, segundo o ministro, em função de uma aliança entre os sábios e os homens de ação que possibilitou a formação de um grande Império que deu novos mundos ao mundo. Embora o ministro das colônias refira-se às glórias do passado, seu discurso não assume um ar predominantemente saudosista: Portugal possuía, então, amplos domínios na África, na Ásia e na Oceania, ${ }^{9}$ que, neste momento, ganharam ainda maior importância em um projeto político que conferia às colônias um papel crucial. No discurso de abertura deste encontro de Alta Cultura Colonial temos o apelo aos sábios para que se juntem aos homens de ação e aos líderes - o Estado Novo na dura tarefa de fazer reviver as glórias de períodos anteriores. O seu público era composto da elite colonialista do período: os dirigentes, os administradores e as mais altas personalidades do saber colonial português. Sábios e homens de ação, grandes chefes e heróis.

É com o Estado Novo, mais do que em qualquer outro período anterior, que os homens de letras, arte e pensamento são chamados a se pronunciarem sobre a obra portuguesa de colonização. Nas falas do então ministro há clareza no que se refere à importância do saber para a possibilidade da ação colonial. Colonizar significa, antes de

Uma análise mais detida do episódio da morte de Papé encontra-se em Thomaz. (1994).

Neste período, faziam parte do Império Colonial Português os arquipélagos atlânticos de Cabo Verde, São Tomé e Príncipe, as grande colônias continentais africanas de Angola e Moçambique, o enclave de Cabinda e a Guiné "Portuguesa"; na Índia, Portugal possuia os pequenos enclaves de Goa, Damão e Diu, e na China a pequena Macau; na Occania, o Timor correspondia à colônia mais distante da metrópole européja. 

cursivamente, pensar e falar sobre os indivíduos e territórios subjugados, e com isto afir-
mar o poder colonial.

A formação dos grandes impérios europeus veio acompanhada, como territórios que se pretendia subjugar. Assim, o controle material do Oriente se dava de forma concomitante com a fundação de um campo de saber que, embora deitasse suas raízes em uma tradição anterior - a possibilidade de o Ocidente dominar discursivamente bases para um complexo processo de exploração e disciplinamento do Oriente nas ciên-
cias e nas artes.

A mobilização de setores da inteligentsia lusitana em era algo novo. Como os próprios representantes savam de repetir, o período das Grandentantes da intelectualidade da época não se canvimento profundo do saber português Navegações foi conseqüência de um desenvolverdadeira revolução nas ciências e e, ao mesmo tempo, foi responsável por uma reza para o fato de que o descobrimento na Europa Ocidental. Nas suas falas, há claportugueses vieram acompanhados de uma labor conquista de novos territórios realizados por ras e das gentes encontradas que fascinaram o públicritiva e reflexiva em torno das terde mundo européia - imersa ainda na cosmo público europeu e revolucionaram a visão farmacopéia etc. Para estes senhores compromia medieval - e as práticas alimentares, a neo, o problema está, como veremos, emometidos com o projeto colonial contemporâModerna em pleno século XX O renas como repor as glórias dos primórdios da Era parte desta geração ${ }^{10}$ - teria que dar-se em ploração efetivos dos territórios africanos todos os sentidos, no domínio, ocupação e exproduzir um determinado tipo de saber sobre as contais, mas, e sobretudo, na capacidade de

É importante salientar que, sem alcanç as colônias alicerçado em sólidas instituições. Reino Unido no que se refere à fundação çar a magnitude de países como a França ou o que tinham como objeto as colônias, em de escolas, bibliotecas e diferentes instituições bilização - por vezes a mais apaixonada - Portugal setores intelectuais se prestavam à motugueses de além-mar. Este fervor colonialista - torno de temas relacionados aos domínios pornacionalista - não redundou, no entanto, - que se confundia com o fervor patriótico e damente embasado em instituições. Nos difo constituição de um campo de saber soliintelectuais e de quaisquer indivíduos comprontes discursos, fazia parte da demanda dos para a fundação de escolas, universidades e inetidos com as colônias o apoio do Estado cimento acumulado por uma nação "secu e instituições que não só reunisse o conheformação de quadros para a administraçãonte imperial", mas que promovesse a realidade das diferentes províncias do Império. Olal e a produção de saber sobre a Novo representaram, de certa forma uma resposta. Os anos 30 e o advento do Estado possibilidade de retomada dos anos de glória resposta a uma geração que via nas colônias a Um dos expoentes desta geração quc, neste periodo, era um entusiasta do renascimento imperial, foi o
Capitão Henrique Galvão. Especificamente sobre Galvão vide Thomaz (1995). Sua participação na con-
cepção e produção das exposições é retomada ainda em Thomaz (1994) e Lichtenthater a Thon
(1996). 
Instituições ligadas às colônias e à formação de quadros coloniais existiam em Portugal desde os oitocentos. A Escola de Medicina Tropical - criada em 1902 e posteriormente transformada em Instituto de Medicina Tropical (1935) - ou a Escola Superior Colonial - inaugurada em 1906, vinculada à Sociedade de Geografia de Lisboa (1875) procuravam suprir os quadros necessários, no que se refere às colônias, no interior de um quadro institucional paupérrimo, a Escola Médico-Cirúrgica de Nova Gôa se destacava entre as províncias orientais do Império. O Estado Novo não só veio a fortalecer as instituições existentes como criou outras, como a Agência Geral das Colônias. Nos textos, contudo, percebemos a angústia dos intelectuais no que se refere à realidade institucional portuguesa: não parecia corresponder às necessidades do terceiro Império Colonial em extensão - a comparação se fazia aqui com o Império Britânico e com o francês -, e tampouco às exigências do mais antigo Império ocidental existente. ${ }^{11}$

Uma primeira análise das Conferências de 1936 nos mostra que embora não existisse um consenso sobre a realidade das colônias ou sobre "o que fazer" ou o que "foi feito" na África e no Oriente portugueses, um mesmo "tom", uma mesma retórica. e um mesmo conjunto de imagens, perpassam as falas de todos. No interior do debate poderemos observar que, em meio a desavenças, há uma tentativa de demonstrar um conhecimento sobre os colônias, conhecimento este central em qualquer projeto de domínio colonial. Ao falar das colônias, administradores, políticos e intelectuais falam, no entanto, de Portugal: de um país que encontrará na noção de Império a razão de ser da nacionalidade.

Nas Conferências de Alta Cultura Colonial, foi apresentado um total de 15 textos. ${ }^{12}$ Podemos afirmar que, se apenas três tinham como objeto específico a "História" do Portugal colonizador, todos encontravam na história o mote que justificaria não só o tema sobre o qual se propunham dissertar, mas a razão de ser do encontro e do próprio colonialismo português. O projeto político contemporâneo de Portugal enquanto potência colonizadora encontrará na História a sua força propulsora, como fica claro no discurso de abertura do ministro das colônias, Francisco José Vieira Machado:

Dobramos o Cabo Não e transformamos o Cabo das Tormentas em Cabo da Boa Esperança.

E. de então até hoje, na obra colonial, não mais houve Oceanos que não avassa-

11 Se é evidente que o Estado Novo procurou fortalecer as instituições colonialistas existentes e promover a fundação de novas instituições, o panorama institucional era bastante pobre, se comparamos com outros impérios europeus, como o Francês, o Britânico, o Belga ou o Holandès. A inexistência de um Muscu Colonial ou Etnográfico que procurasse reunir coleçôes privadas ou institucionais é o exemplo mais explícito da ausência de uma política global com relação ao fortalecimento de um "saber colonial". Isto está evidentemente relacionado à pobreza "material" do Império Português se comparamos com a riqueza acumulada pelos seus congêneres europeus; não podemos menosprezar, contudo, a figura inielectualmente "estreita" e por outro lado, não podemos esquecer, no entanto, a "estreitez" c o obscurantismo intelectual de Salazar, o ditador. Sobre o quadro institucional lusitano das últimas décadas do salazarismo. vide Pélissier (1979). Sobre a figura de Salazar, vide Figueiredo (1976) e Medina (1993).

12 Dois textos versavam ainda sobre aspectos relacionados à cxpansão da fé católica na dilatação do Império: um, sobre a eugenia e a politica colonial portuguesa; quatro textos procuravam ressaltar a importância de Portugal em diferentes campos de saber científico (geografia, exploração cientílica geral e história natural); outro se propunha dar conta da política sanitária do Império: dois recuperavam a influência do Império nas artes e nas letras; e, por fim, o discurso inaugural do ministro das colônias e um texto sobre a ocupação portuguesa na África contemporânea. 
lássemos, Cabo não que resistisse às nossas arremetidas. Cabo das Tormentas que se nos não antolhasse como transmutável em ( abo da Boa Esperança. (Agência Geral das Colônias, 1936:14)

Processo iniciado "há muito tempo", a obra colonial portuguesa é apresentada como contínua e única. Da conquista Ceuta à "pacificação" dos nativos das colônias africanas nas campanhas militares do início do século XX, a obra colonial portuguesa representa um processo único de uma verdadeira pacificação e transformação de um mundo inicialmente selvagem e indócil: a transmutação do Cabo das Tormentas em Cabo da Boa Esperança corresponde a uma imagem forte, uma metáfora do que poderia ser a obra colonial portuguesa no mundo. Posta a antigüidade da ação colonial portuguesa - esta se perderia no tempo, no período das Grandes Navegações - não haveria relação entre o colonialismo português e outros ismos europeus: estes seriam movimentos novos que, inclusive, necessitaram da própria experiência portuguesa para poderem se realizar.

Na conferência que levava por título "A tradição colonial e política do Império", Agostinho Campos apresenta inicialmente uma breve cronologia com o objetivo de "relembrar como é antiga a tradição colonial portuguesa" (Agência Geral das Colônias, 1936:27). Falar de colonização, para o conferencista, remete aos primórdios da própria existência de Portugal, a um complexo processo histórico onde se aliavam a fundação e a expansão da nacionalidade. Fundada a nacionalidade - em constantes turras com a poderosa vizinha Espanha que também se formava - cabia expulsar o mouro e expandir fronteiras: assim se deu a conquista do Algarve e as primeiras incursões pelo Mar Tenebroso. A conquista de Ceuta, em 1415. marca o início de um processo que Agostinho Campos dilata até o século XX. Vale a pena nos determos em um elemento que surge de forma recorrente nos discursos dos diferentes intelectuais: a relação entre o colonialismo português e os conflitos com a Espanha. De início, caberia lembrar que, no período, o Estado espanhol se encontrava em um conflito que teria como conseqüencia uma das guerras civis mais violentas da história do Ocidente. Os acontecimentos que aturdiam a jovem República Espanhola, a participação estrangeira no conflito, os milhares de refugiados que perambulavam pela península eram seguidos com cautela e atenção pela imprensa e pela intelectualidade portuguesas, sempre temendo o tradicional expansionismo ibérico espanhol. Evidentemente, da mesma forma que em outros lugares, a revolução e guerra na Espanha despertou paixão em Portugal, e combatentes lusos se alinharam às duas frentes de batalha - com uma clara ajuda "não oficial" de Salazar aos rebeldes. A vitória de Franco e a concretização de um "pacto" entre as duas ditaduras ibéricas tranqüilizará aqueles que temiam um reviver do anexionismo castelhano. Neste contexto, a idéia de um Portugal imperial e colonizador parece ser a garantia da independência e da continuidade da nação. Agostinho de Campos resume a tradição política do Império na idéia de que Portugal precisaria crescer para fora da península para ser realmente livre e independente. Um "dilema teimoso: ou império ou província'" (Agência Geral das Colônias, 1936:44), sem meio termo possível, elemento que aparece também na fala de Alfredo Pimenta, que, para discutir os conceitos de Império e Civilização e projetá-los sobre a realidade portuguesa, retoma os conflitos seculares, afirmando a necessidade que teve Portugal de lançar-se ao mar e fechar suas "portas e janelas" ao continente para convencer os vizinhos ibéricos de sua personalidade. Para este autor, o Império nasce deste 
"querer viver" de Portugal; Portugal, sem o Império, corre, portanto, o risco de deixar de existir. ${ }^{13}$ Dilema teimoso, retomado por estes intelectuais, que tem assombrado a História de Portugal desde os finais do século XVI, quando da unificação ibérica...

A relação entre o colonialismo português contemporâneo e os primeiros séculos da existência de Portugal como nação independente fica clara na insistência com que os autores se referem ao período áureo das Grandes Navegações. A criação e a dilatação do Império aparece como conseqüência natural e necessária da gestação e fundação da nacionalidade, e o colonialismo português no século XX surge tributário destes dois momentos da história de Portugal: a fundação da nacionalidade e a construção do Império Ultramarino nos séculos XV e XVI.

Se nos detemos nos participantes deste encontro de Alta Cultura Colonial que se dedicaram a dissertar sobre os avanços da ciência e o colonialismo, percebemos a recorrência com que procuraram enfatizar o aspecto pioneiro de Portugal nos avanços tecnológicos e científicos dos primeiros séculos da era moderna. Assim, Quirino da Fonseca em sua comunicação se propõe a tratar de "cinco séculos de contribuição portuguesa para os conhecimentos geográficos" (Agência Geral das Colônias, 1936:182), relatando o conhecimento português sobre o mar e territórios distantes - e o que estes conhecimentos supuseram em termos de desenvolvimento científico e de alargamento das fronteiras do mundo conhecido. Na sua fala, Campos reedita as leituras da viagem de Colombo realizadas em Portugal por ocasião das celebrações do IV Centenário da Descoberta da América, afirmando a importância do período que o almirante passou em Portugal, no qual adquiriu os conhecimentos ali disponiveis. ${ }^{14} \mathrm{O}$ autor se concentra, assim, nos séculos XV, XVI e XVII, dedicando, de um total de 26 páginas, apenas uma à contribuição lusitana ao saber geográfico nos séculos XVIII, XIX e XX. Isto não impede, no entanto, que o o autor transforme a colonização portuguesa - em qualquer período da história em um verdadeiro épico, e que dedique páginas e páginas ao heroísmo que teria caracterizado a expansão desde os seus primórdios.

Da mesma forma, sobre "Os portugueses e a exploração cientifica do Ultramar", Luiz de Pina, então professor de História da Medicina da Universidade do Porto, para referir-se à situação dos conhecimentos científicos do ultramar, volta aos primórdios da expansão lusitana. Naquela época, as descobertas portuguesas alimentaram a ciência européia que desabrochava. Os navegadores e conquistadores lusitanos, fascinados e assombrados com terras e gentes exóticas, com a fauna e a flora dos territórios tropicais, e sentindo a necessidade imperiosa de compreender e relatar aos que ficavam as preciosidades encontradas, desenvolveram o "espírito de observação, o espírito científico" (Agência Geral das Colônias, 1936:215). Segundo o nosso autor, a seriedade e o rigor das descrições eram notáveis. Lança-se então a enumerar os tratados e colóquios de observação da flora, da fauna, de medicina e etnografia do período dos descobrimentos, ga-

13 Os jornais portugueses publicavam extensas matérias sobre o conflito espanhol. Oficialmente, Portugal era neutro diante do conflito, mas as diretrizes do Estado Novo eram claramente favoráveis ao nacionalismo franquista, que parecia mais digerível e menos perigoso do que a República progressista em processo de federalização. Sobre as relações entre Portugal e Espanha nas primeira décadas do século XX, vide Gómez $(1980,1985)$.

14 Sobre a figura de Colombo e as celebrações do IV Centenário em Portugal, vide Simioni (I996). 
nhando destaque inicial a capacidade portuguesa de transplantar espécies vegetais de um território a outro, provocando uma verdadeira revolução nos hábitos alimentares e nas culturas de todos os continentes. Ao longo do seu texto, referências ao Brasil se mesclam com as andanças portuguesas pela África, China ou Ceilão: a descrição minuciosa de novos tubérculos, frutas e vegetais ia acompanhada pela intervenção do homem português na verdadeira criação de um novo mundo.

Foram os portugueses que levaram as laranjeiras para a Índia ocidental e possessões coloniais. A laranja doce introduziu-se em Portugal no fim do século XV (viagem de Vasco da Gama); conhecida na Africa Oriental, breve ai se espalhou a sua cultura. Ass suas boas qualidades tecem santos elogios o Padre Manuel da Nóbrega e Frei Gaspar da Cruz (laranjeiras do Brasil e da China). Somente no século XVII (I635) esta última é plantada no Brasil. (Agência Geral das Colônias, 1936:221-222)

A exploração da botânica provoca, evidentemente, uma verdadeira transformação no que se refere às práticas terapêuticas européias. Os compêndios quinhentistas sobre as drogas e especiarias das Américas, África e Oriente são relacionados então pelo autor, que se estende então pelos séculos XVII e XVIII: os seiscentos, marcados pela ocupação espanhola e perda de brilho do Império, representa a decadência da História Natural; os setecentos, a tentativa de recuperação e o empuxo representado pelos ventos iluministas e pela figura de Pombal. O século XIX surge como um período sem glória em praticamente todos os campos do conhecimento, embora o autor procure recuperar as iniciativas governamentais com relação a implementação legal das investigações no ultramar português - investigações que, como o próprio autor recorda, jamais foram realmente realizadas.

No que se refere à Antropologia e Etnografia, Luiz de Pina afirma a importância dos textos portugueses na descrição e reconhecimento dos mais variados tipos exóticos da América, África c do Oriente. Romper os limites do mundo conhecido a partir de uma dimensão crescente do humano nas suas mais variadas manifestações parece ter sido, para o nosso autor, uma labor iniciado e mantido, sobretudo, pelos heróis da grei. O papel dos missionários no labor descritivo dos tipos humanos e costumes exóticos é ressaltado pelo autor, que novamente recorre às cartas, compêndios e documentos do período das Grandes Navegações, como a carta de Pero Vaz de Caminha e sua descrição dos naturais do Brasil. A medicina também recebe sua atenção, começando pela farmacopéia quinhentista, e finalizando com as atividades dos laboratórios do Ultramar e das Escolas Médico-Cirúrgica de Nova Gôa e Medicina Tropical.

E é partindo do tom apologético dos seus antecessores que Aires Kopke, diretor do Instituto de Medicina Tropical, criado em 1902, se dedica a perfílar as atividades sanitárias portuguesas em territórios tropicais, em particular aquelas desenvolvidas pelo Instituto. Retomar as glórias dos antepassados se traduz aqui em uma ação concreta, em levar a civilização ao nativos. Ao lado da fé - o aspecto missionário retomaremos adiante - e do apoio moral e material trata-se de minorar os sofrimentos advindos das moléstias, resultado do próprio clima tropical e dos maus hábitos e vícios dos povos que habitam estes territórios. Kopke relata aqui as pesquisas levadas a cabo por médicos portugueses em torno das patologias exóticas no período contemporâneo, ressaltando ainda a importância dos grandes congressos internacionais de Medicina Tropical, um deles realizado em Luanda em agosto de 1923. 
Após a leitura da sua conferência - que, é importante lembrar, tem como objeto um dos poucos campos nos quais Portugal destacou-se a partir da formação do ainda existente Instituto de Medicina Tropical -, percebe-se que o movimento contemporâneo de colonização se fazia, no que se refere ao discurso, tendo em conta uma noção de civilização que implica a expansão dos conhecimentos científicos às populações e povos "atrasados". Colonizar significava exportar ciência a povos que ainda permaneciam no obscurantismo da vida tribal e em um cotidiano permeado por elementos mágicos e religiosos. Tratava-se, portanto, de levar a ciência e assim interferir na qualidade de vida dos colonizados. É importante ressaltar, no entanto, que, como afirma o afamado médico, este movimento de política sanitária do Império se faria não apenas em nome da ciência ou da humanidade, mas, e sobretudo, em nome da glória de Portugal.

Civilizar parece possuir, contudo, diferentes significados. No texto do nosso médico, ganha um caráter mais "racional", que aproximaria o colonialismo português de outros movimentos imperialistas contemporâneos, onde o domínio vinha alimentado por uma noção de elevação das populações nativas a estágios mais altos de desenvolvimento humano. A fundação de escolas e hospitais, a construção de ferrovias e rodovias alimentavam a idéia de que colonização possuía, sobretudo, um caráter humanitário, visão esta que nublava outros elementos a ela profundamente relacionados, como a exploração dos recursos físicos das colônias e o aproveitamento de uma mão-de-obra na maioria das vezes impelida compulsioramente ao trabalho. No entanto, o que parece caracterizar, em maior ou menor grau, as falas dos nossos expoentes, é o caráter missionário da colonização portuguesa contemporânea. Vejamos agora uma das características mais marcantes dos discursos dos nossos colonialistas.

A construção de um Império português aparece intimamente relacionada à idéia de vocação imperial. Os portugueses seriam únicos no mundo nesta vocação, que encontraria sua maior expressão no Império Português dos séculos XV e XVI. Esta vocação, plasmada nos feitos dos grandes heróis da grei e na capacidade plástica do povo português em povos e terras tropicais, encontraria na vocação missionária a força que transformaria o Império sobretudo em um ato de Fé. Francisco José Vieira Machado coloca a Fé como um dos elementos centrais na construção de uma Pátria lusitana para além das fronteiras metropolitanas, em uma luta onde a espada conquista os domínios para a Pátria e o evangelho as almas para Deus (Agência Geral das Colônias, 1936:10). Este elemento cristão é retomado diversas vezes como uma das características mais marcantes do colonialismo português, que o deixaria pleno de altos ideais e o transformaria em um movimento único da moderna história da humanidade.

Agostinho Campos refere-se à tradição colonial portuguesa como profundamente cristã. Um cristianismo diferente, particular, cuja marca seria sobretudo a capacidade de ver no Outro, no exóticio, um ser humano; um cristianismo, segundo o nosso autor, mais tranqüilizador para o futuro da raça branca, pois não engendraria ódios ou rancores. Aliás, é neste cristianismo que encontraríamos a capacidade única de expansão da Pátria para além do território europeu.

Tolerância e compreensão dos outros povos são fatores morais ou mentais que muito nos têm ajudado a infiltrar para além dos mares a civilização ocidental. (...)

Continua a tradição política do Império no sutil e instintivo, sábio e natural, inconsciente e certeiro dom da simpatia humana, com que o português atrai e assimila 
o indigena, de modo que a raça colonizadora por assim dizer 'digere' as colonizadas, a tal ponto que não são possiveis com ele nem os problemas de enquistaçâo racial irredutivel, nem as revoltas do civilizado com o civilizador, fáceis de prever ou temer noutras formas de colonização ocidental, ameaçadoras para o Ocidente. (Agência Geral das Colônias, 1936:38,46)

Como vemos, surgem noções como "tolerância" e "simpatia" com as populações nativas, que faria dos portugueses verdadeiros "antropófagos" no processo de atração e assimilação das populações nativas. A plasticidade lusa em gentes tropicais - associada à idéia de antropofagia - fortalece a idéia de que sem as populações exóticas a nação não poderia realizar-se plenamente.

Este mesmo autor retrata de forma magistral o colono português empenhado na sua dura missão de expandir a Pátria e a Fé: o colono português seria pobre. A pobreza não lhe permitia rechaçar o trabalho árduo - diferente dos colonos de outros países europeus, o português trabalharia ao lado do nativo reproduzindo o espírito da Pátria em outras latitudes $^{15}$ - e aproximaria fisicamente o colono lusitano de populações em estágios anteriores de desenvolvimento, facilitando portanto a assimilação destas mesmas populações. A contrapartida material da pobreza material do colono - e, como conseqüencia de Portugal - seria a riqueza de espírito. ${ }^{16}$ Agostinho de Campos procura aqui ressaltar a especificidade da colonização lusitana diante das pretensões e da incompreensão dos outros impérios europeus, quando afirma que:

Uma das nossas esperanças é que nos deixem contimuar a ser pohres parecendo ricos, e ricos parecendo pobres; e que nos não cobicem as riquezas que temos, alegando que não enriquecemos com elas.

A nossa tradição colonial é a da pobreza que fecundou e enriqueceu o Mundo. (Agência (jeral das Colônias, 1936:32)

Referindo-se à ocupação portuguesa na África contemporânea, o General João de Almeida enfatiza o "milagre", o paradoxo existente entre os meios com que contavam e a realização: "sempre fomos poucos e bem poucas vezes fomos ricos" (Agência Geral das Colônias, 1936:420). No entanto, para o general, não se trata de um paradoxo, mas de uma conseqüência do "gênio".

A pobreza do colono - e da Pátria - transforma-se assim em uma metáfora cristã de humildade. Lado a lado com o colono pobre - ou sua mais fiel tradução - surgem os heróis da Pátria que, desde o período das Grandes Navegações, fizeram da colonização uma continuação natural das cruzadas. Alfredo Pimenta, em sua inflamada comunicação, reclama para o Império Português a definição de "milagre de Deus" (Agência Geral das

15 É interessante salientar que o autor utiliza como exemplo a migração portuguesa para o Brasil, onde o imigrante nâo se nega a habitar os lugares mais distantes nem a realizar os trabalhos mais despreziveis

A "riqueza material" como contrapartida à "pobreza material" é salientada uma e outra vez pelos organizadores da Exposição Colonial do Porto de 1934 e pela Exposição do Mundo Português. No primeiro caso, a Exposição do Porto é comparada à Exposição Colonial Internacional de Paris, realizada em 1931; no segundo, a Exposição do Mundo Português tem como contraponto as grandes exposições universais. Henrique Galvão, organizador da exposição portuense e da Seção Colonial da Exposição do Mundo Português, ressalta que a "pobreza material" teria tido conseqüências "sábias", pois explicitaria o "gênio" e a "riqueza espiritual" da pátria lusitana (Thomaz, 1994, 1995; Lichtenthaler \& Thomaz, 1996). 
Colônias, 1936:63), cuja única forma de realização seria o espírito de "missão" que transformaria os colonos em "dianteiros da fé", em "cruzados" e em "soldados de Cristo". Retoma, portanto, a espada e o evangelho como chave explicativa e razão de ser do Império, o que aproximaria, novamente, o colonialismo português contemporâneo à expansão ultramarina dos séculos XV e XVI. À imagem do colono pobre se sobrepõe outra, profundamente religiosa: o sentimento imperialista se caracterizaria pelo orgulho da raça, o amor à glória, o desejo de domínio, e sobretudo, pela fascinação do sacrifício. Sacrifício pela Pátria e pelos seus mais altos ideais de fé e civilização. A noção de sacrifício surge também na fala de Agostinho Campos, que fala do êxito da missão portuguesa a partir da mansidão, do amor e, sobretudo, do martírio.

Da mesma forma, o Reverendo Padre António Ribeiro afirma a vocação missionária de Portugal, ressaltando que, embora o Estado Português não possa tomar para si uma missão religiosa, pois constitui uma entidade política, teria sido um valioso auxiliar das missões católicas e o seu mais insigne benfeitor (Agência Geral das Colônias, 1936:81). No dizer do reverendo, a obra colonial é, sobretudo, uma missão; a colonização portuguesa obedeceria, em pleno século XX, aos mais altos desígnios religiosos. Tal elemento fica claro no texto relativo à história do Padroado do Oriente, escrito por Vasco Borges, onde, em meio ao relato das escaramuças entre Estado e Igreja, observa uma colaboração íntima que possibilita explicar a formação do Império do Oriente e vislumbrar um futuro promissor para a obra de colonização.

Como já afirmamos, este elemento missionário se caracterizaria, sobretudo, pela capacidade cristã de ver no outro um ser humano passível de ser elevado a mais altos estágios de desenvolvimento. Como se colocaria a questão da mestiçagem e da assimilação para estes intelectuais preocupados com o futuro colonizador de Portugal?

$\mathrm{Na}$ fala do próprio ministro das colônias, a questão da elevação dos indígenas ao estatuto de "portugueses" se coloca como uma das particularidades mais belas, e um dos "milagres", da colonização portuguesa. O ministro afirma ter observado uma cena que provocaria no mínimo repúdio a indivíduos de outras nacionalidades européias: no planalto angolano crianças brancas brincavam fraternalmente com crianças pretas diante do olhar benevolente das mães. Tal fato comprovaria a ausência de preconceito de raça entre os portugueses, segundo o ministro, porque todos são portugueses, independente da raça ou do território de nascimento.

Um dos elementos centrais no que se refere a este axioma único da colonização portuguesa é o aprendizado da língua. Longe de promoverem a separação entre os indivíduos, o conhecimento de uma língua comum - o português - permitiria a aproximação e a comunicação entre negros, brancos, amarelos e indianos. O ministro chama ainda a atenção para a política adotada por outras potências coloniais, que incentivam o ensino da língua nativa como forma de garantir a separação entre brancos e negros na sociedade colonial. A noção de que todos são portugueses surge fortemente em vários momentos na fala do ministro e, embora não se tratasse de uma visão absolutamente hegemônica entre os intelectuais, podemos afirmar a importância desta representação já naquele momento, e que será crescente a partir da década seguinte.

Não haveria, no entanto, temor de que neste processo de assimilação e fusão Portugal pudesse perder a sua especificidade diante da massa de indivíduos provenientes de estágios inferiores de desenvolvimento? Para Lopes Vaz de Sampaio, professor da Escola de Alta Cultura Colonial, não haveria este risco: o potencial eugênico dos portugueses 
garante o predomínio do "gênio" na sua mescla com populações tropicais. Segundo o professor, a tendência imitativa do povo dominado está proporcionalmente relacionado ao potencial eugênico do povo dominador e imitado. A reprodução da nação nas colônias estaria assim garantida. A prova contundente o nosso autor encontra no Brasil, onde em meio a uma grande quantidade de negros e indígenas os cromossomos portugueses teriam prevalecido, garantindo no Brasil a continuidade da nação. Em uma fala na qual afirma serem os portugueses os verdadeiros salvadores da raça branca, Lopes Sampaio alerta, no entanto, para a necessidade de o Estado exercer a tarefa de condutor da imigração portuguesa para além-mar. No processo de nacionalização dos territórios coloniais, não basta simplesmente com "aportuguesar" o indígena em um processo de assimilação racial, mas submeter a colonização européia da qual o projeto imperial de nacionalização dos territórios exóticos não pode prescindir - a regras que disciplinem e orientem o seu esforço, fornecendo as bases necessárias para o sucesso do estabelecimento branco sobretudo nos territórios africanos.

Nestas falas onde se evoca a pobreza do colonizador luso, seu caráter sacrificial e sua tendência a assimilar o nativo pela mansidão e pela mescla - sem abrir mão de elementos irredutíveis do "ser português" - um elemento se coloca como problema, visto que a história conforma-se como um dos elementos centrais no sentido de conferir legitimidade ao projeto colonial português: durante pelo menos quatro séculos portugueses e luso-brasileiros foram os principais responsáveis pelo tráfico humano que alimentava de braços as lavouras americanas. Nos primórdios da Era Moderna, Portugal importara uma grande quantidade de escravos para o território continental e povoou de africanos os arquipélagos atlânticos de Cabo Verde e São Tomé e Príncipe. O Brasil, por outro lado, se constituiu como o mais importante importador de mão-de-obra escrava africana, absorvendo boa parte deste contingente destinado ao continente americano. Como rechear de humanitarismo o tráfico negreiro e a escravidão? Estes intelectuais não podiam deixar de referir-se à escravidão, objeto de discussão de vários artigos de $O$ Mundo Português escritos para o grande público. ${ }^{17}$ Retornemos ao texto de Agostinho de Campos, pois este autor nos fornece elementos que serão recorrentes em outros expositores.

Campos salienta um elemento central colocado por Oliveira Martins: a idéia de que a África e o Brasil conformaram, em função do tráfico, um mesmo sistema econômico que, se consumiu a África, possibilitou a emergência do Brasil, "testemunho posterior" do "gênio lusitano" (Agência Geral das Colônias, 1936:29). A base do sistema estaria na carência de braços na América e no excesso de negros na África. A emancipação do Brasil e a abolição da escravidão representaram um novo momento que permitiria o florescer do obscurecido Império Africano. Campos ressalta ainda que se em função do tráfico e da escravidão os portugueses teriam sido muito criticados - lembrando, provavelmente, as campanhas promovidas sobretudo pela Inglaterra contra o tráfico e a escravidão ao

17 É interessante que a temática da escravidão é praticamente ausente nos diversos pavilhões da Exposição Colonial do Porto e da Exposição do Mundo Português, muito provavelmente por ser um tema de difícil representação quando se trata de criar um representação "positiva" da colonização (Thomaz, 1994; Lichtenthaler \& Thomaz, 1996). 
longo do século XIX,$-{ }^{18}$ o colonizador luso teria, sobretudo, sido imitado pelos mesmos que os censuravam. Outro argumento, que surge ao lado da idéia da "mansidão" dos contatos inter-étnicos promovidos pelo colonizador português, é o fato de a escravidão ter sido encontrada, de forma ainda mais bárbara, entre os próprios primitivos africanos. O sistema escravista em territórios sob domínio português e luso-brasileiro seria, portanto, mais brando e, inclusive, humanitário: o negro não só era levado a ter contato com a verdadeira fé, como era salvo dele mesmo, promotor que seria de uma escravidão mais violenta e cruel que contrastava com a benevolência da escravidão portuguesa.

As relações humanitárias dos portugueses com as populações africanas ganha força a partir da insistência na configuração de um reino cristão no Congo no século XVI. Fruto de uma política admirável de D. João II, a proposta de evangelização do Congo, a conversão da família real africana ao catolicismo e a ida dos príncipes congoleses a Portugal para serem educados como senhores portugueses são vistos pelo diretor do Arquivo Histórico Colonial, o historiador Manuel Múrias, como prova do gênio político, do humanitarismo e do caráter missionário do colonialismo português na África. Embora ele reconheça o fracasso da empreitada de formação de um reino Cristão no Congo, esta idéia se fortalece em Portugal, pela manutenção das relações diplomáticas com o os prín-
cipes africanos. ${ }^{19}$

Como podemos perceber, as falas até agora analisadas pretendem construir uma continuidade no tempo entre os primórdios da expansão portuguesa no mundo e a colonização lusa contemporânea, ao mesmo tempo que procuram dotar a ação colonial de um caráter humanitário inato e de ideais superiores. Assim, a pobreza e o martírio viriam acompanhadas da tentativa de elevar o nativo à condição de português, assumindo assim a concepção evolucionista de cultura e civilização em conjunção com o humanismo da fé cristã. Como, no entanto, representar no espaço esta nação dispersa em quatro continentes?

Um dos elementos centrais que perpassa as falas dos nossos expoentes é a idéia de que o Império equivale à nação. A nação é imperial, sua única realização possível é na conquista e colonização de territórios longínquos, processo que teria como conseqüência a transformação destes territórios em "pedaços" da nação espalhados pelo mundo. Alfredo Pimenta chama a atenção para o artigo terceiro do Ato Colonial, de $1^{\mathbb{Q}}$ de agosto de 1935 , que afirma serem "os domínios ultramarinos de Portugal (denominados) colônias e (constitutivos) do Império colonial português" (Agência Geral das Colônias, 1936:68). Portugal e suas colônias formam, contudo, um todo indivisível, e Francisco Vieira Machado repete o artigo primeiro da constituição portuguesa que afirma que Portugal vai "do Minho ao Timor" e lembra que: “(...) tão portuguesa é a mais humilde cubata dos sertões da nossa África, como Porto, Coimbra, Lisboa ou Macau" (Agência Geral das Colônias, 1936:16).

A idéia de que os territórios do ultramar corresponderiam a uma continuação do território metropolitano é alimentada pela noção de que se espirito lusitano se reproduz 18 Não podemos esquecer ainda que Portugal se via às voltas com denúncias de trabalho forçado nas colô-
nias africanas, especialmente em São Tomé.

19 As prematuras relações diplomáticas com o Reino do Congo foram de grande importância para os modernos ideólogos do colonialismo português na África, como ressalta Bender (1980). Henrique Galvão dá grande ênfase nos intercâmbios com o Congo (Galvão, s.d.; Thomaz, 1995) e, inclusive, promove a vinda do Rei e da Rainha do Congo, que ocuparam um pavilhão na Seção Colonial da Exposição do
Mundo Português (Thomaz, 1995; Lichtenthaler \& Thomaz, 1996). 
em qualquer período da história, constantemente igual a si mesmo, isto também se daria no que se refere ao espaço: onde quer que estejam o colono ou o imigrante estaremos em Portugal.

Imagem forte, porém não o suficientemente sedutora para aqueles compelidos a deixar o Portugal metropolitano que antes preferiam emigrar para o Brasil - ou outros territórios americanos - do que partir para a gesta (insegura) que representava a colonização dos territórios africanos ou do Timor. Os intelectuais presentes no encontro tratavam portanto de, nas sua falas, afirmar a lusitanidade dos territórios do ultramar: uma lusitanidade em movimento, um vir a ser. Para tanto, necessitavam convencer o possível colono ou migrante de que ir para as colônias não representava abandonar Portugal, pois o espaço colonial era lusitano na sua essência. Assim, Lopes Vaz de Sampaio afirma que as colônias devem ser tão portuguesas como Portugal, afirmando a reprodução eugênica do colonizador em contato com as gentes exóticas, e da mesma forma o ministro das colônias recoloca a equivalência dos territórios do ultramar com o metropolitano afirmando "tudo é o mesmo Portugal" (Agência Geral das Colônias, 1936:19).

No espaço, como no tempo, Portugal aparece em movimento. As glórias passadas são os trunfos que justificam as empreitadas presentes que podem levar a glórias futuras. Assim, se o Brasil surge como país tentador que atrai o migrante português que o prefere a territórios que constituem parte integrante do seu mesmo Portugal, o próprio Brasil corresponde a uma realidade portuguesa na sua essência, e o "milagre" que lá se verifica pode vir a verificar-se em outras paragens do Império. Percebemos que está em constituição a noção de um mundo português que ocupa diferentes tempos e espaços, mas todos irmanados na sua essência; a independência do Brasil surge como um fato político ora irrelevante, ora revoltante, que não coloca em xeque a existência deste mundo. Contraditoriamente, a existência do Brasil é a prova necessária para a construção de um vir a ser colonial. Como afirma o padre António Ribeiro:

O que aconteceu com o Brasil há de acontecer com os indígenas da Guiné, de São Tomé e Príncipe, de Angola, Moçambique e do Timor. São estes os territórios das nossas missões propiamente ditas, são aqueles povos que nos conferem atualmente os titulos de civilizadores e põem a prova a respectiva capacidade; são eles que justificam a vocação missionária de Portugal. (Agência Geral das Colônias, 1936:92)

O vir a ser da colonização portuguesa não poderia, no entanto, ser uma obra do acaso. A reprodução no tempo e no espaço da essência imperial portuguesa deve ser objeto de reflexão e deve ser produzida pelos sábios e pelos homens de ação. A prova disto estaria no período de decadência que sucedeu a perda do Brasil e caracterizou todo o século XIX e os primeiros decênios do século XX: Portugal abandona as colônias à sua própria sorte e lança-se em medíocres debates políticos internos. O Estado Novo representa para estes intelectuais a possibilidade de um renascimento imperial. São os sábios, que contam com duas autoridades carismáticas: o intelectual, Salazar, e o representante dos homens de ação com uma visão especial, o General Carmona.

A realidade política do Estado Novo representava, para esta geração, a possibilidade de, novamente, Portugal sentir-se um grande Império. Naquele momento, como outrora - lembra o ministro das colônias -, Portugal possuía um grande chefe - Salazar que, sob a égide do Chefe de Estado - o General Carmona -, voltava a conduzir a nação na realização do seu mais alto destino histórico: o Império. A criação de uma mentalida- 
de imperial - que se colocava acima de qualquer ideologia - só se fazia possível no interior de um regime autoritário. Só assim seria possível, como afirmou Manuel Múrias, superar a crise de tristeza e desesperança que havia contaminado Portugal na criação de uma mentalidade imperial avessa à vida morna e tranqüila e desejosa de um cotidiano áspero, duro, incômodo porém iluminado por uma grande esperança.

Não é possível deixar de notar o caráter messiânico destas falas: o Estado Novo se configurava como uma realidade política que possibilitava este pequeno país ressurgir como um grande Império. Falar das colonias, das diferentes províncias que formavam o Império Colonial Português, era falar de um passado glorioso que, a todo o custo, tratava-se de fazer emergir no presente. No processo de domesticar e disciplinar os territórios tropicais e seus habitantes, estes intelectuais transformavam-nos em portugueses. No limite, a realidade das colônias pouco interessava: os mais altos desígnios de Portugal as transformavam em um vir a ser da nacionalidade que delas necessitava para sobreviver.

\section{CONSIDERAÇÕES FINAIS: O LUSO-TROPICALISMO}

Nos discursos de intelectuais vinculados ao projeto imperial, o Império Português é concebido como uma entidade política, material e espiritual única. Esta especificidade viria dada em primeiro lugar pela sua história. O tempo do Império português seria outro, o presente colonial africano e oriental estabelecendo uma continuidade com o período das Grandes Navegações. Por outro lado, um mesmo espírito caracterizaria a empreitada lusitana em qualquer território: o colono português estabeleceria com os povos exóticos relações, em geral, tolerantes e quase igualitárias; com eles aprenderia a lidar com ambientes inicialmente hostis, e a eles ensinaria a língua, a religião e a cultura de Portugal. A fragmentação do território entre os diferentes continentes seria ilusória: ao encontrarmos o mesmo espírito, o mesmo patriotismo, a mesma língua, religião ou cultura, nos depararíamos com uma continuidade de outra natureza. Por fim, o Brasil surge não apenas como um exemplo de uma criação lusitana no passado, mas como a possibilidade de realização no futuro: o mesmo espírito manteria o Brasil próximo à lusa grei, e a independência não teria rompido com os laços espirituais existentes entre Portugal, as diferentes partes do Império e o país sul-americano.

O Brasil surge aqui não apenas como uma criação bem-sucedida de Portugal: é uma imagem forte, a partir da qual Portugal procurará mostrar ao mundo a sua força, aquilo que está ainda em fase de criação sobretudo nos territórios africanos. Se este elemento já aparece em algumas das conferências do encontro de Alta Cultura Colonial e na Exposição do Mundo Português, ${ }^{20}$ é a partir da década de 50 , com o luso-tropicalismo de Gilberto Freyre, que o Brasil ganhará grande proeminência com relação aos destinos do Império.

20 O Brasil participou oficialmente das Celebrações Centenárias de 1940, construindo um pavilhão na Exposição do Mundo Português, inaugurado pelo próprio Getúlio Vargas. Neste pavilhão, o Brasil foi representado como resultado de uma síntese "luso-indígena", não havendo menção à presença africana. O comitê organizador brasileiro enfatizou a qualidade da alta cultura nacional - arte e literatura -, os produtos exportados pelo Brasil, como o café e, sobretudo, a modernidade e o dinamismo da jovem nação. Sobre o pavilhão do Brasil, vide Lichtenthaler \& Thomaz (1996). 
O luso-tropicalismo começa a tomar corpo na obra de Gilberto Freyre a partir do final dos anos 30, com a publicação de O Mundo que o Português Criou (1940), fruto de conferências proferidas pelo sociólogo pernambucano $\mathrm{em}$ universidades européias, em especial portuguesas. Será, no entanto, nos anos 50 que Freyre se dedicará mais intensamente a definir o seu projeto luso-tropical, sobretudo a partir de uma viagem que realiza a Portugal e às suas colônias na África e na Índia. Em cada uma de suas paragens profere discursos e conferências, reunidos num livro de nome Um Brasileiro em Terras Portuguesas. Em cada "província", 21 do Portugal metropolitano ou d'além-mar, Freyre exalta. as características peculiares da colonização lusitana e dos seus cinco séculos de história.

A forma pela qual Freyre nos apresenta o seu livro é bastante significativa. Após uma conferência inicial proferida no Instituto Vasco da Gama, em Goa, na qual expõe o seu projeto sociológico luso-tropical, os seus discursos se sucedem, se entrelaçam, conectando Goa a Lisboa, Bragança e Guimarães; o Portugal europeu à Guiné Portuguesa e a Cabo Verde. Do arquipélago cabo-verdeano, a seqüência nos leva à Ilha da Madeira, da Madeira a São Tomé e então às terras continentais africanas de Angola. De Angola a Moçambique: neste território da África oriental Freyre discursa diante da elite "lusoafricana" local, nas associações indianas e chinesas e também para a "gente de cor" 22 e para os negros. De Moçambique ao Porto, do Porto a Lisboa, finalizando com um discurso no Brasil, proferido no Palácio Rio Negro diante do Presidente da República. ${ }^{23}$ A ordem na qual Freyre nos apresenta a seqüência de textos e discursos confere unidade a um espaço inicialmente fragmentado, algo que já observamos na representação legal dos territórios coloniais ou no famoso mapa intitulado "Portugal não é um País Pequeno". 24

Partindo de Portugal, extremo ocidental da Europa, Freyre refaz a geografia do Império. Em pleno século XX, como os antigos navegadores portugueses, Freyre liga a Europa à África, ao Oriente e à América. Em cada um de seus discursos, exalta as particularidades da colonização portuguesa, enaltece o seu passado e engrandece o seu projeto de futuro; conecta o período das Grandes Navegações com o presente colonialista lusitano: uma única linha no tempo que não deve ser interrompida. "Espaço" e "tem-

21 É importante salientar que, neste momento, as colônias passam a denominar-se "provincias ultramarinas". Desta forma, Portugal se protege de qualquer interferência no que passam a ser "problemas internos". Para maiores informações sobre a politica portuguesa no que se refere às relações internacionais e o problema colonial, vide Bender (1980).

22 O uso que se faz aqui da expressão "gente de cor" corresponde a "mulato"

23 Gilberto Freyre discursou diante do então Presidente da República Getúlio Vargas, a quem entregou um cofre contendo uma edição rara d'Os Lusiadas enviada pelo Chefe de Estado português. Com relação a Os Lusiadas. Freyre afirma ser "(...) este livro tão do Brasil quanto de Portugal, tão do Portugal da Europa quanto do da África e do Oriente (...)" (Freyre, 1953a:266).

24 Este mapa foi apresentado na Exposição Colonial do Porto e contribuía para a sensação de grandiosidade e continuidade na extensão do Império: com o titulo "Portugal não é um País Pequeno", a superfície do Império Colonial Português era sobreposta ao mapa da Europa. Na comparação, Portugal emerge com uma extensão territorial maior do que os grandes paises europeus. É curioso o fato de que a comparação é feita entre a totalidade do Império português e as metrópoles de outros impérios, excluindo pois da medida as extensões dos territórios sob dominação francesa ou britânica, cuja superfície superava, em muito, a extensão dos territórios portugueses do ultramar. Essa matemática singular revela que se concebia Portugal como uma unidade territorial distinta, na sua natureza, das outras nações imperiais (Lichtenthaler \& Thomaz, 1996). Sugiro aqui que esta operação se reproduz na fala de Freyre. 
po" são apresentados de forma contínua: se delineia, enfim, o princípio de identidade que Freyre diz existir entre todos os "tempos" e "espaços" marcados pela colonização portuguesa.

O Brasil desempenha no seu discurso um papel fundamental, pois configura a prova material do bem-sucedido esforço colonial português. A sua emancipação política não questiona a unidade do "mundo português": o Brasil seguịria lusitano no "espírito". 25 Freyre retoma, de forma simplificada, a síntese já construída em Casa-Grande \& Senzala: o grande país sul-americano seria exemplo da "convivência harmoniosa" de raças, credos e culturas, ${ }^{26}$ a oposição existente entre a casa-grande e a senzala, entre a casagrande e a mata tropical, inicialmente intransponível dada a diferença racial e cultural e, sobretudo, devido à violência do regime escravocrata, teria sido nuançada pela particularidade do colonizador português. O desejo do homem lusitano - viril - pela mulher morena, negra ou índia, e posteriormente cabocla e, sobretudo, mulata, teria dado origem a um grande número de mestiços que uniria fraternal e umbilicalmente a casa-grande à senzala, a casa-grande à mata tropical. Nos seus discursos luso-tropicais, Freyre vê, na África, Brasis em gestação: nas colônias portuguesas da África e do Oriente, observa mundos antagôni$\cos$ - o do colonizador e o do colonizado - aproximando-se fraternalmente. Nestes espaços luso-tropicais se constataria o mesmo fenômeno já observado no Brasil: a convivência racial, cultural e religiosa romperia oposições e amortizaria o conflito.

A presença de fulas islamizados na Guiné convivendo e colaborando com o colonizador português leva Freyre a enaltecer a tolerância religiosa, que caracterizaria não só a Guiné, mas todas as colônias portuguesas, especialmente Goa, Damão e Diu, onde, além dos católicos e muçulmanos, teríamos os hindus e os parses convivendo lado a lado.

Se constituiria, enfim, uma identidade entre os diferentes territórios colonizados por Portugal. Esta identidade seria dada, inicialmente, pela natureza: clima, flora exuberante e colorido tropical. As plantas que germinam na Índia podem germinar em territórios das mesmas latitudes da África e das Américas. Isto, no entanto, só seria possível graças à intervenção do homem lusitano.

A identidade seria fruto, ainda, de uma história comum, que nos uniria todos ao período das Grandes Navegações e que teria criado um padrão cultural de relacionamento inter-racial, e permitiria ao viajante brasileiro reconhecer o Brasil e os brasileiros seja em Portugal, seja nas colônias africanas ou orientais.

É interessante notar que Freyre viaja às colônias portuguesas da África e do Oriente para comprovar uma teoria já formada anteriormente: a colonização portuguesa em qualquer época e em qualquer lugar viria marcada por constantes que definiriam os rumos dos territórios colonizados independente dos seus habitantes. Freyre não se dedica a realizar uma etnografia dos locais que visita, nem observações sociológicas relevantes: observa aquilo que the interessa para confirmar aquilo que já conhece.

25 É a busca deste "espírito" lusitano que orienta as observações de Gilberto Freyre em toda a sua viagem. A noção de "espírito" lusitano é pré-concebida, e Freyre não faz mais do que confirmar as suas certezas
a partir do que observa na África e no Oriente.

26 As aspas são importantes aqui, pois Freyre nunca negou a violência característica da colonização. Esta violência, descrita em inúmeras páginas de Casa-Grande \& Senzala, não negaria, no entanto, o ideal harmônico de relaçðes raciais que daria origem ao Brasil a partir das relações intimas estabelecidas entre a Casa-Grande e a Senzala, entre o Sobrado e o Mocambo. Uma belíssima análise deste elemento na primeira obra de Freyre pode ser encontrada em Araújo (1993). 
Se algo surpreende Gilberto Freyre não é a especificidade de cada um dos lugares que visita, mas as semelhanças que podem conectar o Brasil com cada uma das colônias portuguesas da África e do Oriente. Estas semelhanças só seriam possíveis devido à peculiariedade da presença portuguesa nos trópicos: estes se modificariam no contato com as terras e as gentes tropicais. O luso-tropicalismo implica uma aculturação em mão dupla: a lusitanização do nativo se daria da mesma forma que o colono se americaniza, se africaniza, se orientaliza; leva aos nativos a sua fé e a sua língua - não as impõe -, e aprende com os nativos elementos da sua cultura que possibilitem a sua presença nos territórios tropicais.

Freyre conecta, por fim, o presente colonial português ao período das Grandes Navegações, e vê na obra colonial portuguesa do século XX uma nova idade do ouro. A identidade construída por Freyre entre as diferentes colônias e o Brasil cria uma noção de continuidade no tempo e no espaço semelhante àquela da Exposição do Mundo Português. Novos elementos se somam aqui, renovando a Cultura do Império: a sensualidade dos territórios e dos povos tropicais - que Freyre transformara em chave explicativa da cultura brasileira - faz dos trópicos, da África e do Oriente um lugar atraente, onde se repetiria a façanha realizada no Brasil, a criação de um complexo cultural que tende à harmonia e se distancia do conflito.

Gilberto Freyre procura solucionar antigos dilemas e paradoxos já observados com relação a um conjunto de intelectuais comprometidos com o projeto colonial português: como projetar a "nação" no corpo político do Império? Como dar conta da diversidade racial e cultural de um Império fragamentado no tempo e no espaço e marcado - como todos os Impérios contemporâneos - pela desigualdade entre colonizador e colonizado? Como legitimar o projeto colonial diante da catástrofe que se aproximava?

Diversas soluções discursivas são elaboradas. A mais radical vem do próprio ditador, quando mais de uma vez elimina o problema a partir de uma máxima que não se cansava de repetir: "África não existe". Os intelectuais das Conferências de Alta Cultura Colonial e, posteriormente, Gilberto Freyre, são mais sofisticados, e será numa noção bastante peculiar de "tempo" e de "raça" que se propõem a dar conta da "nação" e do Império. No "tempo", encontram o alicerce último do projeto colonial. Não apenas na legitimidade que conferiria uma "história" antiga e cheia de heroísmo: é no futuro da colonização portuguesa em territórios tropicais. O vir a ser da colonização teria que se garantido não apenas porque dele dependia a própria existência da "nação" - como desejavam os intelectuais de 36 . A partir de 50 se elabora a noção que o "futuro" da presença lusa nos trópicos deveria ser garantido pois dele dependia a criação de novas realidades harmônicas e avessas à violência racial que assombrava as colônias das demais potências européias e atormentava os Estados Unidos e a África do Sul. A segurança última das "boas intenções" do projeto colonial viria dado pelo Brasil, que os intelectuais de 36 já observam como configurando uma realidade única no que se refere às relações entre os diferentes tipos raciais, e que Gilberto Freyre desenha, sobretudo na sua fase luso-tropical, como uma democracia racial.

Duas questões se colocam: o que se entende por "raça" neste contexto e qual a necessidade da existência do Império como corpo político, visto que o Brasil seguiu o seu rumo "natural" após a sua emancipação política não se distanciando da lusa grei?

Como bem demonstrou Ricardo Benzaquen de Araújo (1993) na primeira parte do seu trabalho sobre Casa-Grande \& Senzala e a obra de Freyre na década de 30, a noção 
de raça - tão empregada até então pelos intelectuais brasileiros como chave explicativa seja da nossa especificidade, identidade ou atraso - não é abandonada pelo sociólogo pernambucano. É no conceito neolamarquiano de "raça histórica" que Ricardo Benzaquem encontra a articulação feita por Freyre entre "raça" e "cultura": a formação final de um novo "tipo racial" que garantiria pelo menos a promessa de homogeinização da nação. Sugiro aqui a simpatia com a qual receberá a intelligentsia colonialista da época esta concepção de raça: ao meio ecológico e à dinâmica migratória se juntará a ação colonial portuguesa - que promoveria a miscigenação - na criação de novos mundos lusotropicais, com novas "raças" relativamente homogêneas onde o elemento português jamais se perderia, antes se afirmaria na sua capacidade de reprodução nos povos exóticos. A razão de ser da nacionalidade estaria, novamente, na sua capacidade antropofágica: a essência, o espírito, se manteria; a nação é um contínuo vir a ser; o "milagre" observado no Brasil nos primórdios da sua colonização está em gestação nos territórios coloniais, por isso a necessidade da permanência do Império; os povos exóticos não seriam mais do que verdadeiros portugueses - sem sabê-lo. Caberia ao Estado garantir a continuidade do Império e da missão, e com isto, a continuidade da nação.

\section{AGRADECIMENTOS:}

A Pedro Puntoni, Emerson Giumbelli, Fernanda Peixoto, Ângela Alonso e John Monteiro pela leitura cuidadosa e pelos comentários.

\section{REFERÊNCIAS BIBLIOGRÁFICAS}

AGÊNCIA GERAL DAS COLÔNIAS, 1936. Conferências de Alta Cultura Colonial. Lisboa: Agência Geral das Colônias.

AGÊNCIA GERAL DAS COLÔNIAS, 1947. Coletanea de Legislação Colonial. Lisboa: Agência Geral das Colônias.

AGERON, C. R., 1984. L'Exposition coloniale de 1931: Mythe républicain ou mythe impérial. In: Les Lieux de Mémoire: I. La République (P. Nora, org.), Paris: Gallimard.

ARAÚJO, R. B., 1993. Guerra e Paz: Casa-Grande \& Senzala e a Obra de Gilberto Freyre nos anos 30. Tese de Doutorado, Rio de Janeiro: Museu Nacional, Universidade Federal do Rio de Janeiro.

BANCEL, N. (org.), 1993. Images et Colonies. Iconographie et Propagande Coloniale sur lAfrique Française. Paris: BDIC-ACHAC.

BALANDIER, G., 1993. A noção de situação colonial. Cadernos de Campo - Revista dos Alunos da Pós-Graduação em Antropologia da Universidade de São Paulo, 3:107-131.

BENDER, G., 1980. Angola sob o Domínio Português. Lisboa: Sá da Costa.

BENEDICT, B., 1993. The Anthropology of World's Fairs: San Francisco's Panama Pacific International Exposition of 1915. Berkeley: Scholar Press.

CORBEY, R., 1993. Ethnographic showcases, 1870-1930. Current Anthropology, 8:338-369.

FIGUEIREDO, A., 1976. Portugal: 50 Anos de Ditadura. Rio de Janeiro: Civilização Brasileira. 
FRANÇA, J. A., 1985. A Arte em Portugal no Século XX. Lisboa: Bertrand.

FREYRE, G., 1940. O Mundo que o Português Criou. Rio de Janeiro: José Olympio.

FREYRE, G., 1953a. Um Brasileiro em Terras Portuguesas. Rio de Janeiro: José Olympio.

GALlo, D., 1988. O Saber Português: Antropologia e Colonialismo. Lisboa: Heptágono.

GALVÃO, H., s.d. Outras Terras, Outras Gentes. Porto.

GIRARDET, R., 1972. L'Idée Coloniale en France. Paris: La Table Ronde.

GOMEZ, H. T., 1980. Na Encruzilhada da Grande Guerra. Portugal - Espanha (19131919). Lisboa: Estampa. GOMEZ, H. T., 1985. Do "Perigo Espanhol" a Amizade Peninsular. Portugal - Espanha
(1913-1919). Lisboa: Estampa.

HOIDER, C. \& PIERRE, M., 1991. L'Exposition Coloniale. Paris: Complexe.

LICHTENTHALER, W. B. \& THOMAZ, O. R., 1996. O mundo que o Português criou. In: Entre o Mito e a História: o V Centenário da Descoberta da América (P. Montero, org.), pp. MOUTINHO, M., 1980. História da Etnologia Portuguesa. In: Introdução à Etnologia. Lis-
boa: Estampa. PÉLISSIER, R., 1979. Le Naufrage des Caravelles: Estudes sur la Fin de l'Empire Portu-
gais (1961-1975). Paris: Éditions Péllissier.

PÉLISSIER, R., 1983. Observaciones sobre la reciente historiografia de Angola y Mozambique. In: La Historiografia del África Austral, Barcelona: Serbal/Unesco PÉLISSIER, R., 1986. História das Campanhas de Angola: Resistência e Revoltas (1845-
1941). Lisboa: Estampa.

PÉLISSIER, R., 1987. História de Moçambique: Formação e Oposição (1854-1918). Lis-
boa: Estampa. PÉLISSIER, R., 1989. História da Guiné: Portugueses e Africanos na Senegâmbia (184I-
1936). Lisboa: Estampa.

PORTELA, A., 1987. Salazarismo e Artes Plásticas. Lisboa: Icalp.

ROSAS, F.,1994. História de Portugal: o Estado Novo. Lisboa: Estampa.

SAIAL, J., 1991. Estatuária Portuguesa dos anos 30 (1926-1940). Lisboa: Bertrand.

SAID, E., 1990. Orientalismo. São Paulo: Companhia das Letras.

SIMIONI, A. P., 1996. A invenção da figura de Colombo. In: Entre o Mito e a História: o $V$

Centenário da Descoberta da América (P. Montero, org.), pp. 255-290, Petrópolis: Vozes.

STOCKING, G., 1987. Victorian Anthropology. New York: The Free Press.

STREET, B., 1992. British popular anthropology: exhibiting and photographing the other. In: Photography and Anthropology (E. Edwards, ed.), New Haven: Yale University
Press.

THOMAZ, O. R., 1994. O Império no Porto: Representações sobre a Colonização Portu- 
guesa no Século $X X$. Ensaio apresentado como conclusão do Programa de Formação de Quadros Profissionais do Cebrap, São Paulo.

THOMAZ, O. R., 1995. O mais português de todos: o mundo português de Henrique Galvão. Trabalho apresentado no XVIII Encontro Anual da Anpocs, Caxambu.

\section{CATÁLOGOS DAS EXPOSIÇÕES E CONGRESSOS:}

Álbum Comemorativo da Primeira Exposição Colonial Portuguesa, Porto, 1934.

Álbum Comemorativo das Festas Centenárias de Guimarães, do Cortejo do Mundo Português, e da Secção Colonial da Exposição do Mundo Português, Lisboa, 1940a.

Domingos Alvão: Álbum Fotográfico da I⿳亠 Exposição Colonial Portuguesa, Porto, 1934.

Comemorações Centenárias. Programa oficial, Lisboa, 1940.

Conferências de Alta Cultura Colonial, Lisboa, 1936.

Congressos do Mundo Português. Congresso Colonial, 3 vols., Lisboa, 1940.

Catálogo da Exposição Histórica da Ocupação, Agência Geral das Colônias, Lisboa, 1937, 2 vols.

Exposição do Mundo Português. Seção Colonial, Lisboa, Neogravura, 1940b.

Pavilhão do Brasil na Exposição Histórica do Mundo Português, Lisboa, 1940.

\section{PERIÓDICOS}

O Mundo Português - 1934/194I

Diário de Notícias - 1934/1940

Diário de Lisboa - 1934/1940

O Comércio do Porto - 1934/1935 


\section{O CULTURALISMO DOS ANOS 30 NO BRASIL E NA AMÉRICA LATINA: DESLOCAMENTO RETÓRICO OU MUDANÇA CONCEITUAL?

\author{
Lourdes Martínez-Echazábal
}

La cultura es un discurso, un lenguaje, y como tal no tiene principio ni fin y siempre está en transformación, ya que busca constantemente la manera de significar lo que no alcanza a significar. Es verdad que al ser comparado con otros discursos de importancia el político, el económico, el social, el discurso cultural es el que más se resiste al cambio. Su deseo intrínseco, puede decirse, es uno de conservación, puesto que está ligado al deseo ancestral de los grupos humanos de diferenciarse lo más posible unos de otros. De ahi que podamos hablar de formas culturales más o menos regionales, nacionales, subcontinentales y aun continentales. Pero esto en modo alguno niega la heterogeneidad de tales formas. Un artefacto sincrético no es una sintesis, sino un significante hecho de diferencias. (La Isla que se Repite. Antonio Benítez Rojo, 1989: xxvi-xxvii)

\section{INTRODUÇÃO}

Uma crítica da cultura hispano-americana afirmou em 1980:

Não encontraremos na reflexão norte-americana, nem na brasileira, a mesma veemência, e até obsessão, com que os hispano-americanos têm sentido a necessidade de definir a sua cultura no contexto ocidental, de identificar-se diante das diversas formas de colonização, de criar um sentido e um método de conhecimento para sua realidade histórica. (Chiampi, 1980:96)

Foi esta afirmação categórica e radical que, a princípio, fez-me refletir sobre os discursos específicos e as práticas diversas no interior desse núcleo continental que chamamos América Latina. Para começar, devo dizer que não concordo com o enunciado acima. Primeiro, porque não se trata de encontrar a "mesmice", ou de medir, para comparar, o grau de "veemência" ou "obsessão" de uma ou outra reflexão político-intelectual; mais importante é buscar os nexos possíveis entre elas. Em segundo lugar, basta uma rápida e superficial passada de olhos na extensa bibliografia crítica, bem como na rica e prolífera produção artística relacionada com os temas de identidade nacional, pensamento social, caráter nacional e cultura brasileira para evidenciar que carece de suporte o argumento. Em outras palavras, concordar com sua proposição significaria apagar e reescrever, como um palimpsesto, a criação artístico-intelectual e a história do pensamento social e político brasileiro.

Caso não indicado o contrário, são minhas as traduções e as ênfases das/nas citações de outros autores ao longo deste capítulo. 
Indubitavelmente, uma das preocupações recorrentes do pensamento latino-americano, incluindo o brasileiro, tem sido a de compreender o que é que significa "ser latino-americano" e mesmo o que é a América Latina e como se constitui, se expressa, evolui e se transforma dentro de seus respectivos contextos nacionais, assim como em relação à Europa e, mais tarde, aos Estados Unidos. Claro que essa preocupação ontológica, distintiva e fundante aflora muito antes da invenção geopolítica da América "latina", inclusive antes dos primeiros rebentos anticolonialistas e/ou republicanos no continente e nas suas ilhas. Testemunhos disso são os textos de cronistas, missionários (em particular os jesuítas), poetas e viajantes que passaram por estas terras. Não obstante, é a partir da segunda metade do século XIX que a referida preocupação ontológica, ou o que mais apropriadamente chamaria de hermenêutica da identidade latino-americana (brasileira, mexicana, argentina, cubana etc.), detona com maior intensidade na literatura e na exegese de cientistas sociais, impondo-se como tópico central no pensamento intelectual e político em diversos países que hoje constituem a América (já não tão "latina"). E vemos, em síntese, que a referida hermenêutica trata de explicar - e nesse processo vai construindo -, aquilo que constitui nosso perfil, nossos mecanismos de funcionamento social, político e cultural e, sobretudo, nossas singularidades e nossos traços distintivos perante a outros espaços físicos e modelos culturais.

\section{O IDEOLOGEMA DA MESTIÇAGEM ${ }^{2}$}

\section{0-1910: "To be or not to be"}

Dentro do contexto delineado no parágrafo anterior, chama a atenção o que poderíamos denominar ideologema da "mestiçagem", com suas diferentes variantes nacionais, regionais e de época. Tal ideologema tem ocupado o centro de eloqüentes e inteligentes análises da história e da literatura de "nossa" América. No Brasil das últimas duas décadas do século XIX e da primeira do XX, por exemplo, a mestiçagem torna-se ponto central para a compreensão dos destinos da nação. Nessa virada de século, por exemplo, são evidentes as personalíssimas elaborações que dele fizeram Silvio Romero, Euclides da Cunha, Graça Aranha, entre outros. Profundamente influenciados pelo positivismo, que teve nos tópicos "degeneração", "barbárie" e "enfermidade social" unidades básicas de análise, estes autores viam no cruzamento racial e na educação, se bem que por vezes até de forma conflitiva e incoerentes, ${ }^{3}$ uma possível solução para os

2 Neste trabalho uso, junto com Irlemar Chiampi, o termo ideologema, e não ideologia, para enfatizar a recorrência da mestiçagem como uma das unidades básicas de análise na interpretação dos processos de identidade da América Latina. Agradeço a meu colega do Departamento de Lingüística da Universidade da Califórnia/Santa Cruz, professor William Ladusaw, por seus valiosos comentários acerca da aplicação da terminologia e metodologia da lingüística estrutural a outros sistemas sociais ou textuais, como, por exemplo, o sistema ideológico, representado neste trabalho pelos discursos acerca da identidade culturalnacional na América Latina e do racismo científico positivista do século XIX, entre outros.

3 A respeito da atitude incoerente destes pensadores acerca da mestiçagem, gostaria de compartilhar com o leitor um comentário de Antônio Cândido sobre Silvio Romero, comentário este que se aplica a muitos outros: "Não se pense, porém, que [Romero] tivesse a respeito uma atitude coerente. Ora achava o mestiçamento um bem, pois de outro modo não haveria adaptação do branco ao trópico, ora, com mais pessimismo, julgava-o um mal inevitável, quase humilhante. As mais das vêzes, contudo, tomava-o como fato consumado e se alegrava com as perspectivas de branqueamento final" (Cândido, 1963:106-107). 
males do Brasil - quer dizer, uma das poucas saídas possíveis para o triunfo e regeneração da etnicidade branca no País (vide Lima \& Hochman, neste volume; Martínez-Echazábal, 1984, 1990, 1996; Ventura, 1991; Schwarcz, 1993), ${ }^{4}$ assim como uma "forma de dar aos elementos africanos e indígenas uma expressão nacional, incorporados a projetos pretensamente sincréticos, que constituíram formas de hegemonia dos setores tidos como superiores em termos étnicos ou culturais"' (Ventura, 1994:1).

Em contrapartida, havia outros intelectuais mais radicais que consideravam a mestiçagem um verdadeiro perigo para a boa saúde do País e da etnicidade branca. Entre eles acha-se Nina Rodrigues, que promoveu a tese da degeneração racial provocada pela mestiçagem. Acreditava que na mistura de raças muito distanciadas encontrava-se a razão para certas doenças, tais como as epidemias, ou a loucura, cujas origens deviam-se a uma "fraqueza biológica" ou ao "subdesenvolvimento psicopsicológico" inerente ao mestiço, o brasileiro nato. ${ }^{5}$ Portanto, para os estudiosos da história das mentalidades na América Latina os leit motifs do ideologema da mestiçagem elaborado nas últimas décadas do século XIX mostram-se extremamente ricos do ponto de vista analítico na medida que revelam não só o impacto do desenvolvimento nas ciências e na tecnologia na virada do século XIX mas, sobretudo, a terrível ansiedade das elites em assimilar os avanços do mundo civilizado, o "ser moderno", e fazer parte da grande comunidade ocidental.

\section{A reinvenção da raça: 1910-1920}

Com a entrada do século XX, o discurso do racismo científico sofre um deslocamento e, por influência da antropologia cultural boasiana, começa a ser gestada na escrita e nas artes da América "latina" a dissociação entre raça e cultura. Com ela emerge uma série de paradigmas que tem como meta a regeneração e reivindicação da identidade mestiça do homem latino-americano no contexto ocidental. ${ }^{6}$ Nos discursos elaborados com base no ideologema da mestiçagem emergentes nos anos 20 já não se fala, em geral, de raças ou culturas "inferiores" para efeito de exclusão, se bem que isto esteja implícito; pelo contrário, enfatiza-se uma inevitável e "natural" síntese de culturas baseada no contato e na cooperação entre as diversas civilizações.

Ou seja, as primeiras décadas do século XX representam um momento chave no desenvolvimento do pensamento ocidental moderno, momento em que "[o]s europeus, norte-americanos e latino-americanos estavam descobrindo que o mundo estava povoado por poucas raças, muitas mesclas e um sem número de culturas [...]'' (Ianni, 1993:23).

Vide também o seguinte comentário de Silvio Romero: "Esta são as idéias que propagamos para que, pelos meios educativos, pela instrução, pela seleção, pela mescla de bons elementos étnicos de contingentes imigratórios superiores, espalhados em todo o Brasil, especialmente nas magníficas terras do Centro e do Norte, nos regeneremos"' (Romero, 1980:1549).

Diz Nina Rodrigues; "Dos mestiços, eu não pretendo certamente que sejam todos irresponsáveis. Tanto importaria afirmar que são todos degenerados [...]. Mais acredito e afirmo que a criminalidade do mestiço brasileiro é, como todas outras manifestações congêneres, sejam biológicas ou sociológicas, de fundo degenerativo e ligada às más condições antropológicas do mestiçamento no Brasil" (Nina Rodrigues,
1938:215-216). 
Portanto, não é de surpreender que, a partir dos anos 20, a mestiçagem, percebida como elemento fundante e favoravelmente diferenciador, funcione como suporte das novas interpretações culturalistas. Contudo, o problema racial da "nossa América mestiça" "7 não desaparece; pelo contrário, persiste através do preconceito social, quer dizer, através da identificação de posições de classe socialmente construídas e materialmente determinadas com base em raça. Voltarei a este tema adiante.

Discutir as raízes locais desta mudança retórica e pretensamente conceitual iria além do permissível, ou aceitável, num ensaio desta natureza. Conformo-me em assinalar que, ainda que o termo "étnico" tenha ganhado uso mais generalizado no período do pós-guerra com a finalidade de evitar o uso do termo raça, ${ }^{8}$ a reinvenção da raça qua etnicidade começou a ser gestada nas primeiras duas décadas do século XX nas várias performances das culturas primitivas postas em voga pelas vanguardas européias, sobretudo nas artes plásticas e na música. Por sua vez, no continente americano, a Revolução Mexicana de 1910 com seus exércitos de camponeses índios e mestiços ocupando um primeiro plano visual nos jornais da época (e mais tarde nos murais de Diego Rivera c outros representantes da arte nacionalista mexicanos, tais como Orozco, Siqueiros e até o próprio Rufino Tamayo) também forma parte deste processo de gestação de um conceito que marcou definitivamente o pensamento social latino-americano. Estética e política juntaram-se num ato de inclusão e "penetração" até então impensável no âmbito da cultura ocidental e da política latino-americana, tendo por agentes indivíduos, temas e problemáticas excêntricos a elas, e até então considerados "primitivos" e "bárbaros". A meu ver, este ato de inclusão e "penetração" é o que prepara o terreno para a subseqüente teorização do conceito de raça enquanto etnicidade na escrita latino-americana.

\section{O discurso da etnicidade: dos anos 20 aos 50}

A escrita de sociólogos, antropólogos, políticos e literatos latino-americanos nos anos 20 e 30 testemunha esse processo que estava sendo gestado no interior do pensamento ocidental a partir da primcira década do século XX. As reflexões metacríticas de Fernando Ortiz, o sociológo, antropológo e teórico da cultura afro-cubana, assim como as de seu contemporâneo Arthur Ramos, reconhecido antropólogo do negro no Brasil e "continuador incansável da obra de Nina Rodrigues"' (Valente, 1977:3), são ilustrativas dessa transformação. Nos anos 30 estes dois intelectuais refletiram sobre a obra de duas figuras importantíssimas do pensamento cubano e brasileiro de finais do século XIX: José Martí e Nina Rodrigues, respectivamente.

Em um trabalho apresentado originalmente em 1934, e publicado em 1941, intitulado Martí e as Raças, Ortiz sugere que a chave para a compreensão das reflexões de Martí em relação à questão racial encontra-se na forma em que ele "reduz' a noção de raça (biológica):

\footnotetext{
$7 \quad$ Frase célebre utilizada por José Martí para se referir ao continente americano.

8 Segundo Stolcke (1991:106), configurava-se numa tentativa de enfatizar que "os grupos humanos cram um fenômeno histórico c cultural e não categorias de pessoas biologicamente determinadas exibindo traços hereditários comuns em termos morais e intelectuais" (vide também Santos, neste volume).
} 
significado social de ser um grupo humano histórico, mais cultura do que natureza [...]. [Martí] sabe que 'nossa América' não é 'nossa raça' no sentido biológico, pois é composta de uma variedade de diversas cores, crânios e cabelos; de um emaranhado de todas as raças do mundo, não importando quais sejam ou como a antropometria mais arbitrária queira defini-las. [Na escrita de Martí], raça quer expressar cultura, como atualmente se diz, ainda que esta acepção do vocábulo não estivesse em uso há 60 anos, quando Marti escrevia. (Ortiz. 1993:121)

Cinco anos mais tarde, seguindo a linha traçada por Ortiz, as palavras introdutórias de Arthur Ramos em livro póstumo de Nina Rodrigues - As Collectividades Anormaes (1939) - também dizem respeito a disassociação entre raça (biológica) e cultura:

Uma única ressalva podemos fazer aqui, ao trabalho do mestre bahiano." E quando faz intervir o slogan da época: a degenerescência da mestiçagem como causa precípua dos desajustamentos sociais [...]. Essas idéias são inaceitáveis para os nossos dias. O pretenso mal da mestiçagem é um mal l.../ mais social do que orgânico. Se, nos trabalhos de Nina Rodrigues, substituirmos os termos raça por cultura, e mestiçamento por aculturação, por exemplo, as suas concepções adquirem completa e perfeita atualidade. (Ramos. 1939:12-13)

Aceitar, sem ressalvas, as propostas de Ortiz e Ramos significaria colocar Martí e Nina Rodrigues no topo da lista de precursores da mudança paradigmática mencionada anteriormente e que na América L atina materializou-se excmplarmente na obra de Gilberto Freyre, e nos escritos de Ortiz e Ramos, entre muitos outros. Antes de prosseguir, valeria a pena, em nome de uma maior complexidade crítica, questionar a "tradução" que Ortiz e Ramos fazem das idéias de José Martí e Nina Rodrigues. Segundo Ortiz, Martí rejeita o conceito estrito de raça biológica mediante uma conceptualização dos grupos humanos enquanto raças, digamos, históricas, cuja essência pode ser definida como "mais cultura que natureza". De fato, Ortiz parece indicar que, se o termo cultura não é empregado, isto decorre de uma falha do sistema lingüístico, ou seja, do próprio processo de significação, na medida em que a correspondência entre o significante "raça" e o significado "cultura" ainda não havia sido elaborada teoricamente. Ou, como afirmou Ortiz em outro momento, "a acepção do termo ainda não estava em uso". Ramos, por sua vez, considera que o "problema" na obra de Nina Rodrigues pode ser eliminado facilmente através da substituição de um termo por outro. Apesar de eticamente preocupante, o caráter simplista e mecânico da fórmula de Ramos é bastante revelador, uma vez que implicitamente sugere que a chamada dissociação entre raça e cultura foi mais um deslocamento retórico que conceitual.

A meu ver, o que tanto Ortiz como Ramos buscavam era reatualizar a obra de seus antecessores (e pais intelectuais) ante às novas tendências da antropologia cultural dos anos 30, que explicitamente rejeitava posturas racistas como as que caracterizavam a obra de Nina Rodrigues em particular. No caso de Ramos, tratava-se também de defender a obra do mestre das críticas de alguns de seus contemporâneos que, aparentemente, "entendiam mas não compreendiam" o verdadeiro significado de sua obra. Para tanto,

9 Segundo Sacramento Blake (1969), Raymundo Nina Rodrigues nasceu no Maranhão e não na Bahia, no dia 4 de dezembro de 1862. 
era inicialmente necessário convencer os leitores que o equívoco foi mais da ciência e das idéias filosóficas dominantes da época do que de Martí ou Nina Rodrigues. Nesse processo de resgate e/ou defesa, ainda que Ortiz e Ramos tenham contrariado o paradigma de "raça" biológica através da glorificação da mestiçagem cultural, o que remete à rejeição dos postulados do racismo científico de finais do século XIX, utilizaram critérios culturalistas racializados na sua argumentação. Ou seja, findaram por aceitar e utilizar acriticamente o discurso da etnicidade.

$O$ discurso culturalista da etnicidade encontrou solo fértil para seu florescimento na América Latina. Entre os vários paradigmas culturais baseados no ideologema da mestiçagem que abrem novos horizontes interpretativos da cultura latino-americana a partir dos anos 20 podemos citar os seguintes: a "antropofagia" no Brasil na década de 20; a "raça cósmica", miolo da utopia tropicalista do mexicano José Vasconcelos (1925) (Vasconcelos, 1982); a "cor cubana", metáfora através da qual o poeta cubano Nicolás Guillén textualiza e teoriza em 1931 a idéia de mestiçagem cultural (Guillén, 1981); a "transculturação", contrapartida teórica da noção de "aculturação", teoria desenvolvida pelo sociólogo cubano Fernando Ortiz em 1941 (Ortiz, 1978); o "real maravilhoso", paradigma elaborada pelo novelista e ensaísta cubano Alejo Carpentier no prólogo de um de seus romances publicado originalmente em 1949 (Carpentier, 1971). Estes são alguns dos tantos modelos interpretativos da cultura e da identidade latino-americana com base no ideologema da mestiçagem que surgem a partir dos anos $20 \mathrm{com}$ o objetivo de reivindicar o mestiço e a mestiçagem e postular a cultura latino-americana como "cadinho de raças" de onde sairia uma cultura (racializada) capaz de eliminar o conflito entre os opostos, entre os antagonismos tradicionais, como região/nação, branco/não branco, (neo)colônia/metrópole, cidade/campo, civilização/barbárie. Contudo, subjacente a todos estes modelos encontra-se a idéia de raça biológica travestida em etnicidade ou em classe social. Um outro ponto de suma importância é que em todos estes ideologemas acontecem simultaneamente uma culturalização da raça e uma racialização da cultura.

Vários são os críticos que nos últimos anos têm assinalado o deslocamento de raça à cultura no pensamento latino-americano. Pessoalmente, ao me aproximar uma vez mais deste tema, o faço com cautela, consciente que raça é um conceito fluido e transformante, embora historicamente específico, de modo que seu significado é fruto das teorias, interesses e discursos sociais da época em questão (Golberg, 1993:74). Daí que raça, como um modo socialmente construído de identificação e diferenciação da espécie humana, possa ser qualificada mediante o uso de inúmeros adjetivos, tais como biológica, histórica, cultural ou social. Segundo a época, estes termos, por sua vez, podem assumir outros valores retóricos e/ou conceituais em relação ao substantivo que modificam. Tal é o caso ao nos referir, junto com Goldberg (1993), à raça qua cultura, qua classe, e qua nação. ${ }^{10}$

\section{Uma viagem de ida e volta: cultura, cor e classe}

$\mathrm{Na}$ sociedade latino-americana, os conceitos "cultura", "cor" e "classe" adquirem uma desmesurada importância a partir da década de 20 com a rearticulação e afirma10 Para uma nítida discussão da raça qua cultura, classe e nação, vide Goldberg (1993), em particular o ca-
pítulo intitulado "As máscaras da raça". 
ção do ideologema da mestiçagem e frente aos discursos edificantes de reconstituição do Estado-nação, e suas respectivas culturas nacionais. No caso brasileiro, por exemplo, sua relevância faz-se patente a partir dos anos 20 , através do choque conceitual, na luta pelo poder interpretativo e definidor da brasilidade entre o modernismo paulista e o nordestino; entre o discurso heterofóbico, corporativista e anti-regional de Oliveira Vianna, e o discurso heterofílico, tradicionalista e regionalista de Gilberto Freyre; ${ }^{11}$ entre a poética cosmopolita e paródica dos manifestos e a poesia de Oswald de Andrade e a regionalista, à marxista, de um novelista como Jorge Amado; ou, visto de uma outra maneira, entre o discurso da "brasilidade bem-nascida" (aquela que foi imaginada tradicionalmente como soma de três raças) e aquele dos "novos brasileiros" que emergia das áreas agrícolas e industriais do Sul e Sudeste do País" (Guimarães, 1994:21).

Por não ser possível abordar devidamente estes inúmeros autores neste ensaio, enfocarei dois em particular: Gilberto Freyre e Jorge Amado. Além de enfocar as peculiaridades na elaboração do ideologema da mestiçagem por ambos, pretendo analisar que relações guardam as versões brasileiras com aquelas elaboradas em outros países latinoamericanos como, por exemplo, a "raça cósmica" do José Vasconcelos e a "cor cubana" do Nicolás Guillén. Assim, qual é o valor discursivo e ideológico atribuído à raça, à cor, à classe e à cultura? ${ }^{12}$ Colocada em outros termos, a questão central é a seguinte: a dissociação entre raça e cultura, assim como a euforia culturalista que marca a escrita latino-americana a partir da década de 20 , resulta de deslocamento retórico, de mudança conceitual ou de ambos?

Vejamos como se deu a "reinvenção", ou rearticulação, do conceito de raça no período em questão. Se no Brasil dos anos 20 o que parecia prevalecer era o ideário racista com que Retrato do Brasil (1928), de Paulo Prado, "culminara a visão desfavorável das raças que integram o povo brasileiro" (Chiampi, 1980:123), no México José Vasconcelos - escritor filósofo e político, secretário de Educação Pública entre 1921-1924, e ideólogo por excelência do então recentemente formado Partido Revolucionário Institucional (PRI) - publica A Raça Cósmica (1925). Segundo a crítica, esta obra iniciou em nível continental a valoração da mestiçagem. Fortemente influenciado pelas idéias de Nietzsche, como bem assinalado por Jorge Schwartz (1995:531), Vasconcelos profetiza a fusão étnica dos opostos numa "raça sintética", numa "quinta raça universal". A tese central é que "as distintas raças do mundo tendem a se misturar cada vez mais, até formar um novo tipo humano, composto da seleção de cada um dos povos existentes" (Vasconcelos, 1982:9). Um dos aspectos que mais chama a atenção nesta passagem é a afirmação de que da mestiçagem entre as diversas raças sairá um "tipo humano" e não um "tipo nacional". Este é um ponto importante, dado que para a maioria dos teóricos da mestiçagem, profundamente comprometidos com ideários nacionalistas, a mestiçagem repre-

11 Neste contexto o termo heterofóbico denota a fobia a diferenças raciais, regionais e culturais. Dai resulta o impulso arianizante c centralizador que caracteriza o discurso de Oliveira Vianna em Evolução do Povo Brasileiro. Em contraste com o discurso de Oliveira Vianna, o de Freyre é heterofilico na medida em que proclama a influência e celebra, pelo menos no nivel cultural, as contribuições das diferentes raças, religiões, e regið̌s à formação do povo brasileiro.

12. A pergunta anterior tem como pano de fundo um questionamento de caráter mais geral sobre "se "etnicidade' [classe] e 'raça' são fenômenos interligados (por um denominador comum de caráter essencial] ou referem-se a sistemas distintos de classificação social" (Stolcke, 1991:107). 
sentava o método oportuno para a formação do "tipo nacional" (vide Seyferth, neste volume, e Ramos, também neste volume). Ainda que o cristianismo de Vasconcelos relacione-se estreitamente à dimensão humanista e universalista de sua teoria, seu lado inovador poder-se-ia explicar, também, pelo fato de que para Vasconcelos "o trópico", e não o México, seria o "locus privilegiado" dessa nova "raça sintética", portadora de "uma civilização refinada e intensa" (Vasconcelos, 1982:34). ${ }^{13} \mathrm{Na}$ utopia tropicalista de $A$ Raça Cósmica, a terra prometida ficaria localizada na região que hoje compreende os territórios do Brasil, Colômbia, Venezuela, Equador, partes do Peru e da Bolívia e o norte da Argentina.

Ora, se Vasconcelos não chega a abandonar a idéia de raça biológica, nem tampouco rompe com o darwinismo social, com o determinismo geográfico ou com o evolucionismo que caracterizaram as várias elaborações do ideologema da mestiçagem no século XIX, ao menos desenvolve um aspecto que o distingue de outros formuladores. Distintivo em seu discurso é precisamente o processo através do qual esta "síntese feliz" acontecerá, qual seja, "a misteriosa eugenia estética" prevalecerá sobre a eugenia científica (Vasconcelos, 1982:41):

[o]s tipos inferiores da espécie serão absorvidos pelo superior. Assim poderia remirse, por exemplo, o negro, e pouco a pouco, por extinção voluntária, as estirpes mais feias irão cedendo espaço às mais belas. As raças inferiores, ao se educarem, tornarse-iam menos proliferas. [Deste modo], os melhores espécimens ascenderão numa escala de melhoramento étnico, cujo tipo máximo não é precisamente o branco, mas essa nova raça, a que os próprios brancos terão que aspirar com o objetivo de conquistar a sintese. (Vasconcelos, 1982:42-43)

A propósito, qual seria o tipo étnico e a cor dessa "nova raça" a qual até os brancos terão que aspirar para conquistar a "síntese"? Creio que uma das possíveis chaves para a compreensão da passagem anterior e, conseqüentemente, da utopia futurista de Vasconcelos, encontra-se no uso do advérbio "precisamente". Na medida que a "nova raça" não é exatamente branca (mas poderia ser), o uso do advérbio coloca a ambigüidade como figura central no texto, relativizando o uso da cor branca (a "nova raça" poderia ser, também, "quase" branca). ${ }^{14}$ Em suma, a "raça cósmica" foi pensada como uma raça espiritual, inclusive fisicamente mestiça, mas de uma cor clara, a mais clara possível.

Retornemos ao Brasil. Na década de 20 coube a Oswald de Andrade proceder a ruptura - se é que podemos falar de uma - com o paradigma de raça em favor de uma visão culturalista/nacionalista. Mas foi o discurso simultaneamente moderno e conservador de Freyre em Manifesto Regionalista (1926), em Casa-Grande \& Senzala (1933) e, posteriormente, em Sobrados \& Mucambos (1936) o que mais chama a atenção por causa de

13 Em 1922, por ocasião da comemoração do Centenário da Independência do Brasil, Vasconcelos visitou o Brasil como chefe da delegação mexicana. Foi tal a impressão que o país the causou - "os esplendores de uma Natureza cheia de potências, generosa de hábitos, resplandecente de claridades" (Vasconcelos, 1982:34) -, que três anos mais tarde escreveu em $A$ Raça Cósmica: "[o] panorama do Rio de Janeiro atual ou o de Santos com a cidade e a sua baía podem-nos dar uma idéia do que será esse empório futuro da raça cabal, que está por vir"' (Vasconcelos, 1982:34).

14 Uma outra forma possivel de nos aproximarmos do discurso de Vasconcelos - se bem que relacionada com a anterior - é a partir da análise de sua caracterização da etnicidade branca latino-americana. Tratase de um tópico cuja extensão não permite tratamento adequado neste trabalho. 
seu impacto (e permanência) tanto nos discursos políticos e acadêmicos quanto no imaginário popular. Talvez não seja novidade dizer que, sobretudo, Casa-Grande \& Senzala é a obra que desmente aquela "verdade" assentada na obra de Oliveira Vianna (1923), preocupada com a "evolução do povo brasileiro"' e sua projeção futura em termos homogêneos. Reconstituindo a história social de uma sociedade heterogênea e pretensamente harmônica, a obra de Freyre marcou de forma iniludível as relações inter-raciais no Brasil. Se concordamos com a afirmação de que o "cenário do século XIX mostrava no conflito dos opostos a própria crise da sua identidade cultural"' (Chiampi, 1980:107), então poderíamos ler Casa-Grande \& Senzala como uma tentativa neo-romântica de harmonizar, de encontrar um equilíbrio entre opostos, convertendo-os em elementos constitutivos de uma totalidade cujas partes mantêm uma relação dialética.

O discurso de Freyre é marcado tanto pela continuidade como pela ruptura. A distinção que o autor estabelece entre raça e cultura caracteriza uma ruptura com os discursos sociais de sua época, temperados ainda pelo pensamento científico e filosófico do século XIX, que promovia conceitos racistas e deterministas acerca da relação e dependência entre raça e cultura. Não obstante, encontra-se em Freyre, bem como na maioria dos pensadores latino-americanos das décadas de 20 a 50, a permanência de uma lógica racial que, embora explicitamente culturalizada, mantem alguns nexos com o passado. ${ }^{15}$ Tal lógica racialista, como mais recentemente demonstrou Ricardo Benzaquen de Araújo (1994:31-32) no contexto de Casa-Grande \& Senzala, reside no interior mesmo da linguagem. Em minha opinião, contudo, tal lógica já havia sido explicitada no Manifesto Regionalista, através de sua apologia de um Nordeste em decadência, assim como em seu elogio da cultura crioula, berço da chamada "democracia racial", e, segundo o autor, "a principal bacia em que se vêm processando essas combinações, essa fusão, essa mistura de sangues e valores que ainda fervem [...]' (Freyre, 1955:48). Assim, as tradições da região apresentam-se não só racializadas como também "brasileiríssima[s]" (Freyre, 1955:48). ${ }^{16}$ Por sinal, o próprio Manifesto Regionalista ilustra o que foi dito:

A verdade é que não há região no Brasil que exceda o Nordeste em riqueza de tradições ilustres e em nitidez de carácter. Vários de seus valores regionais tornaramse nacionais depois de impostos aos outros brasileiros menos pela superioridade econômica que o açúcar deu ao Nordeste durante mais de um século do que pela sedução moral e pela fascinação estética dos mesmos valores... Como se explicaria, então, que nós filhos de região tão criadora, é que fôssemos agora abandonar as fontes ou as raizes de valores e tradições de que o Brasil inteiro se orgulha ou de que se vem beneficiando como de valores basicamente nacionais?

$15 \Lambda$ pretensa dissociação entre raça e cultura, o deslocamento retórico no âmbito destes conceitos e os processos de racialização da cultura e da culturalização da raça na escrita latino-americana - incluída parcialmente a obra de Freyre -, são alguns dos temas com os quais tenho trabalhado nos últimos doze anos, tanto em cursos de pós-graduação como em pesquisas e publicações (Martínez-Echazábal, 1984, 1988, 1990a, 1990b, 1992, 1996). Acerca de alguns destes tópicos vale mencionar a articulada e inteligente análise de Ricardo Benzaquen de Araújo (1994) em seu recente livro sobre Casa-Grande \& Senzala e a obra de Gilberto Freyre nos anos 30 .

16 Este comentário de Freyre lembra-me a caracterização do Brasil em uma música popularíssima do compositor Ary Barroso, qual seja, "Aquarela do Brasil": " ... esse Brasil lindo e trigueiro é o meu Brasil brasileiro..." 


\section{[...] Apenas nos últimos decênios é que o Nordeste vem perdendo a tradição de}

criador ou recriador de valores para tornar-se uma populacão quase parasitária ou uma terra apenas de reliquias: o paraíso brasileiro de antiquários e de arqueólogos. (Freyre, 1955:19-21)

A passagem acima deixa entrever uma marcada ansiedade por defender os valores tradicionais do Nordeste e conservar seu papel de protagonista no cenário nacional no que tange à formação da brasilidade e da cultural nacional, se não no nível ecônomico e político, pelo menos no simbólico. O papel de "criador ou recriador de valores" começou a ser disputado, primeiro, pela brasilidade mineira e, mais tarde, por aquela dos "novos brasileiros", cuja influência econômica, política e simbólica passou a se desenvolver por volta de $1900 \mathrm{em}$ torno da economia cafeeira no Sul e Sudeste e que em poucos anos transformou a paisagem urbana da cidade de São Paulo a ponto de convertê-la em capital financeira e cultural do País.

A apologia do Nordeste representa também um elogio à mestiçagem e à cultura crioula, tópico que será mais amplamente elaborado por Freyre $(1936,1957)$ em Sobrados \& Mucambos e Casa-Grande \& Senzala. Freyre caracteriza a cultura crioula como uma cultura de "antagonismos em equilíbrio", autárquica, de natureza híbrida e muito plástica, na qual existe uma "zona de confraternização" onde brancos, negros, mestiços, mulatos, amos e escravos conviviam num clima de intimidade e mútua cooperação. Uma cultura caracterizada pelo excesso que, desdobrando-se a partir da natureza tropical e do sistema escravista, adentrava-se nos costumes e, sobretudo, na conduta sexual. Aliás, segundo Benzaquen de Araújo, "o excesso sexual, é, de fato, o principal responsável pela constitução daquelas 'zonas de confraternização' que contrabalançavam, até certo ponto, o despotismo típico da escravidão"' (Araújo, 1994:64-65).

É importante ressaltar que esse "retrato do Brasil" não é peculiar a Freyre nem aos anos 30. Seis décadas após a publicação de Casa Grande \& Senzala, o legado freyreano persiste e se faz presente em reflexões contemporâneas sobre a nacionalidade e o papel da sexualidade e da mestiçagem, algumas delas marcadas por excessos retóricos e patriarcais. Recentemente, por exemplo, num ato de ventriloquismo freyreano, Darcy Ribeiro afirmou: " $[n]$ ós, brasileiros, [...] somos um povo [...] mestiço na carne e no espírito [no "sangue" e na "alma", segundo Silvio Romero, em "corpo" e "alma", segundo Freyre], já que aqui a mestiçagem jamais foi crime ou pecado" (Ribeiro, 1995:447).

Por meio de uma reciclagem simbólica, Ribeiro rearticula a poética freyreana (do mesmo modo que Freyre rearticulou alguns dos postulados básicos da poética romeriana) sobre a relação entre sexualidade, mestiçagem, criador e essa "zona de confraternização", outorgando-lhe, através do advérbio de lugar ("aqui"), um locus de influência ainda mais amplo. Quer dizer, se para Freyre o Nordeste em geral, e a Plantação ${ }^{17} \mathrm{em}$ particular, constituem os limites de suas reflexões - se bem que por meio deles estabelece uma relação metonímica com a nação -, com Ribeiro esse marco geoconceitual estende-se e passa a ocupar explicitamente todo o território nacional.

17 Utilizo o termo "Plantação" em maiúscula seguindo a definição de Antonio Benitez Rojo "para indicar não só a existência de plantaçðes senão também do tipo de sociedade que resulta do uso e abuso delas" (Benitez Rojo, 1989:xii). 
Por mais que se possa discordar de suas idéias no presente, uma vez situado em seu próprio contexto político, econômico e social, não surpreende o fato de Freyre - filho da oligarquia açucareira e do Nordeste - ter escrito em 1936 uma apologia proustiana da mestiçagem e do Nordeste. Mas certamente causa surpresa que, em 1995, um antropológo e romancista reconhecido internacionalmente afirme que "a mestiçagem jamais foi crime ou pecado", o que me parece um lastre desnecessário num momento em que, teórica e politicamente, procura-se desarticular os discursos coloniais da mestiçagem e as relações "confraternizantes" entre amos e escravos, particularmente no que tange ao sexo feminino. Ao se referir à mestiçagem como uma prática social santificada pela sociedade brasileira e ao ignorar os meios de extrema violência e sadismo com que, por vezes, os "senhores" submetiam as mulheres das "raças inferiores", Ribeiro não só torna os brasileiros cúmplices de um crime coletivo como também coloca-se no contrafluxo da crítica contemporânea.

Mas certamente não é minha intenção neste trabalho polemizar com Darcy Ribeiro, senão examinar a rearticulação ou "reinvenção" do conceito de raça na década de 30 na América Latina, e em particular no Brasil. Retornemos a Freyre. Segundo sua argumentação em Sobrados \& Mucambos, com a decadência do patriarcado rural a cultura crioula deixa de ser o centro de gravidade e, com isto, esvai-se a conceitualização da mestiçagem como simbiosis. ${ }^{18}$ Os antagonismos, outrora em equilíbrio, começam a se manifestar de maneira direta em oposições binárias; "ou' passa a substituir à eufemística ' \&", quer dizer, casa-grande ou senzala, sobrados ou mucambos, amos ou escravos, brancos ou negros. Porém, não sendo possível manter por mais tempo uma situação de precário equilíbrio, recai sobre o mulato o papel de eliminar e sintetizar os antagonismos entre as diversas raças, "castas" e classes sociais próprias das sociedades de Plantação. Aliás, certas passagens da obra de Freyre podem ser lidas quase como uma extensão dos argumentos de Silvio Romero, um dos mais destacados intelectuais de um outro importantíssimo momento (1880-1910) para a formação intelectual da nação brasileira, para quem a mestiçagem era "a forma nova de diferenciação nacional" e o mestiço (leia-se mulato) o "agente transformador' por excelência da cultura nacional. Assim, a teoria freyreana torna a mestiçagem em sintesis ${ }^{19}$ e o mulato em ícone da democracia racial e social. Tal democracia, "pela sedução moral e pela fascinação [...] (Freyre, 1955:19)" humanista de suas proposta, estabelece-se como ideal do qual até hoje "o Brasil inteiro se orgulha" e através do qual o Nordeste logrou se perpetuar no imaginário nacional, eternizando "a tradição de criador ou recriador de valores" que, segundo Freyre, a região "vem perdendo" (Freyre, 1955:21).

Possivelmente o aspecto mais importante da obra de Freyre para uma discussão da "reinvenção" - ou mascaramento, seguindo a linha de análises traçada por Goldberg

$18 \mathrm{Na}$ "simbiosis" as diversas influências não se fundem numa outra entidade; pelo contrário, mantêm-se lado a lado num equilíbrio passível de ruptura. Para uma discussão deste conccito no âmbito da literatura latino-americana, vide Martinez-Echazábal (1990a:capítulo 5) e Araújo (1994:154-155).

19 Na "sintesis", ao inverso da "simbiosis", dá-se a fusão das diversas influências, resultando numa pretensa entidade estável, fixa c acabada. Em minha opinião, a elaboração do ideologema da mestiçagem enquanto "sintesis" - que, segundo Araújo (1994:30), "daria ao Brasil a oportunidade de superar o 'inacabamento' [...] que habitualmente o caracterizava' - choca-se frontalmente com esta outra conceptualização do ideologema da mestiçagem no qual a mistura racial é o próprio cerne do processo evolutivo de branqueamento, de um vir-a-ser que, no futuro, redimirá o País (Cam) da "maldição", de Noé. 
(1993) - da raça qua cultura e qua classe nos anos 30 é aquela premissa básica enunciada num dos parágrafos mais citados de Casa-Grande \& Senzala, e de sua obra em geral:

Todo o brasileiro, mesmo o alvo, de cabelo louro, traz na alma, quando não na alma e no corpo [...] a sombra, ou pelo menos a pinta do indigena ou do negro [...]. [E, mais concretamente], [n]a ternura, na mímica excessiva, no catolicismo em que se deliciam nossos sentidos, na música, no andar, na fala, no canto de embalar menimos pequenos, e em tudo que é expressão sincera de vida, trazemos quase todos a marca da influência negra. (Freyre, 1957: 279)

Esta passagem esvazia a "cor" de seu significado biológico e a resignifica cultural e espiritualmente em "corpo" e "alma". Tal resignificação, segundo Freyre, aconteceu na sociedade escravocrata brasileira e permitiu que se criasse a ilusão de uma maior mobilidade na estratificação social, de uma "quase perfeita igualdade de oportunidade para todos os homens a despeito de raça e cor" (Freyre, 1963:7). Assim, Freyre faz com que a idéia de "raça social" seja incorporada ao imaginário social brasileiro, se bem que este conceito teve que esperar mais duas décadas para ser elaborado de forma paradigmática ao discurso das ciências sociais no Brasil, ${ }^{20}$ embora não na literatura.

Já os romances de Jorge Amado (1977, 1978, 1980), em particular aqueles originalmente publicados entre 1935 e 1937 - Jubiabá, Mar Morto e Capitães de Areia -, baseiam-se num projeto artístico-político-cultural que conjuga compromisso sociopolítico (de corte marxista) com interesse pela cultura afro-brasileira (baiana), dois sistemas com pressupostos diferentes - um científico, outro mítico. Amado, seguindo o impulso antropofágico delineado por Oswald de Andrade (1972) em seus manifestos, constrói um produto artístico mestiço que, como a obra de Freyre, nega a cor (física) como elemento endêmico da noção de raça, colocando em seu lugar a noção de cor espiritual, corporificada nos conceitos de cultura afro-brasileira e classe social. A exemplo de Freyre, Amado outorga à raça um valor espiritual - bem como social -, uma vez que o ser negro ou branco ou mulato afirma-se não através da cor da pele, e sim mediante diversas formas social e culturalmente determinadas de apreender o mundo.

Creio que, para os fins deste trabalho, o resumo temático de Brookshaw dos três romances de Jorge Amado acima mencionados - mais que num estudo detalhado das obras - ajuda-nos a compreender a relação entre raça, classe e cultura, assim como as noções de raça qua cultura, e qua classe deste autor:

Ao contrário dos proletários e instruidos heróis de Cacau e Suor, a personagem principal de Jubiabá, o negro Antonio Balduíno, recorre àquela tradição que está mais próxima a ele no desenvolvimento de sua consciência politica. Ele não segue os exemplos de Marx ou Lenin, mas o exemplo de Zumbi dos Palmares, [...]. Mar Morto focaliza a vida de pescadores do porto de Salvador, cujos destinos são guiados pela

20 Já antes de Freyre sabia-se que riqueza, título acadêmico ou uma brilhante carreira militar podiam transformar a noite em dia e que a pobreza, mesmo as práticas "fetichistas" afro-brasileiras, podiam transformar a própria noção de "etnicidade branca" (Nina Rodrigues, 1935:185). Todavia, essas crenças constituíam núcleos isolados do pensamento social brasileiro, situados à margem da retórica oficial do poder (vide Sansone, neste volume). No Brasil o termo "raça social" passou a formar parte do léxico das ciências sociais a partir da coletânea da UNESCO (1952), onde o antropólogo norte-americano Charles Wagley introduz o conceito que, a propósito, já havia sido utilizado anteriormente por sociólogos latinoamericanos (Wright, 1990). 
deusa da água, Iemanjá, a despeito de serem brancos e negros. Em Capitães de Areia, Jorge Amado aborda o tema de crianças abandonadas. O herói, Pedro Bala, atinge um nivel de consciência social através de sua identificação com a mitologia africana, de modo semelhante a Balduino. A diferença é que Bala é branco [...]. (Brookshaw, 1983:132)

Vistos em conjunto, como tríptico das "classes" marginais de Salvador (estivadores, pescadores, e meninos da rua, respectivamente), percebe-se nestes três romances um deslocamento explícito no âmbito da "cor". Fenotipicamente, observa-se o deslocamento da cor negra (de Balduíno) à branca e negra (dos pescadores) à branca (de Bala); no âmbito social, todavia, esse deslocamento implica um "enegrecimento" dos brancos, na medida em que estes passam a compartilhar uma consciência de classe. Embora esses deslocamentos não sejam gratuitos, curiosamente o elemento mediador, o fator catalisador, é a cultura (e mitologia) afro-brasileira (baiana). Com um gesto simultâneo de aceitação e rejeição, os três romances de Amado, vistos em conjunto, confirmam, por um lado, a frase célebre de Nina Rodrigues em relação ao poder "corrosivo" da religião afro-brasileira: "pode-se afirmar que na Bahia todas as classes [leia-se raça], mesmo a dita superior, estão aptas a se tornarem negras" (Nina Rodrigues, 1935:185), ${ }^{21}$ embora, simultaneamente, a destitua do sentido negativo e de eminente perigo com que fora pensada por este "precursor das Ciências Sociais no Brasil"' (Ortiz, 1983:13). Portanto, ainda de acordo com Brookshaw, poderíamos sugerir que "a mensagem de Amado nesse momento é que na Bahia a cultura negra pertence tanto aos negros quanto aos brancos", (Ortiz, 1983:132). Indubitavelmente, para Jorge Amado o "ser negro" reside além da pele na consciência de pertencer a uma classe social e acreditar numa mitologia africana: a cor é social e cultural.

Proposta similar é veiculada pelo discurso da "cor cubana" elaborado por Nicolás Guillén no prólogo a Songoro Cosongo, publicado em 1931. Ao refletir sobre seus "versos mulatos", Guillén empreende uma viagem de ida e volta desde a noção de raça biológica até a de raça cultural. Ao longo do percurso, aproveita para refletir sobre a condição étnica em Cuba, concluindo que:

[a]s duas raças que na ilha vêm à tona, distantes no que se vê, lançam-se um gancho submarino, como essas pontes fundas que unem em segredo dois continentes. O espirito de Cuba é mestiço. E do espírito à pele nos virá a cor definitiva. Algum dia se dirá: 'cor cubana'. (tradução de Schwartz, 1995:596-597)

Guillén parece indicar que a mestiçagem, além de criar novas fisionomias, gera também um espírito ao qual corresponde, e do qual emergirá um dia, a verdadeira identidade cubana. Pergunto-me, contudo: por ser essa identidade expressa em termos de cor, como é possível que uma abstração (o espírito) possa gerar um fenótipo? Já que, segundo o poeta, esta transmutação é possível, podemos especular sobre a tonalidade dessa "cor cubana" em formação. Será "café com leite", morena clara, branca, negra? Não! Que falha! Negra seria impossível, pois a mestiçagem como forma

21 É interessante observar como já na última década do século XIX, Nina Rodrigues estabelecia uma correlação entre classe e cor independente da noção de raça biológica. Ou seja, um branco (membro da classe "'dita superior') poderia se tornar um negro na medida em que atravessasse a linha invisível, mas extremamente rígida, que separa os civilizados dos não-civilizados, geralmente pessoas de cores escuras. 
de engenharia social (e na qual se baseia a ideologia do embranquecimento) nega essa pos-
sibilidade cromática.

Das colocações do prólogo, podemos abstrair que para Guillén a cultura afro-cubana, como para Freyre e Amado a afro-brasileira, é parte integral da cultura nacional e, como tal, pertence espiritualmente tanto a negros quanto a brancos. Disso resulta que nestas três variantes do ideologema da mestiçagem a cor seja usada simbolicamente como marca cultural-nacional. Daí também que tanto o discurso como a prática da democracia racial nestes dois países revelem semelhanças surpreendentes. Ademais, a relação entre "espírito" e cor estabelecida por Guillén nos faz pensar, concretamente, nas manifestações psicoculturais da mestiçagem referidas por Freyre em Casa-Grande \& Senzala, assim como na negritude espiritual dos personagens de Jorge Amado. Existe, sem dúvida alguma, um diálogo culturalista-essencialista e transnacional que abrange os
discursos de Freyre, Amado e Guillén.

\section{CONCLUSÃO}

Faz mais ou menos uns três anos quando, ao entrar na sala do programa "A Cor da Bahia', do Mestrado em Sociologia da Universidade Federal da Bahia, defrontei-me com o lindo cartaz de divulgação da exposição fotográfica Color Cubano, patrocinada pelo Folkens Museum de Estocolmo, entre 20 de outubro de 1993 e 27 de fevereiro de 1994. Longe da minha própria terra encontrei-me face a face, neste momento, com a "cor cubana". Confesso que fiquei perplexa ante minha descoberta. À guisa de conclusão, gostaria de realizar uma brevíssima leitura do cartaz comemorativo da exposição que, no meu entender, não só celebra e dá publicidade ao evento, como também registra uma mensagem tanto visual como textual que remete de imediato, assim como resignifica, o prólogo de Guillén discutido anteriormente neste trabalho.

Pessoalmente teria muito interesse em saber se as autoras do pôster - a photographer e a texter, segundo as categorias apresentadas no próprio cartaz - tinham conhecimento prévio da genealogia do conceito, bem como de sua relevância para a interpretação da cultura cubana, e quais foram os critérios por elas utilizados no processo. de criação da parceria, nada inocente, entre imagem visual e texto. Para fins da crítica desenvolvida neste ensaio, contudo, é mais produtivo focalizar no nível fenomenológico, quer dizer, no âmbito da percepção, da recepção em termos de leitura, do que ficar tentando decifrar a intencionalidade das autoras-criadoras deste texto cultural.

Conforme já assinalei anteriormente, um dos traços característicos da "cor cubana', assim como de todas as variantes do ideologema da mestiçagem, é a expectativa frente a um futuro, frente a um vir-a-ser. Quando escreveu seu prólogo em 1931, é óbvio que para Guillén a "cor cubana" ainda não havia se concretizado, estando em processo de formação. A escolha do título da exposição, reproduzido no cartaz, parece cumprir a profecia do poeta. Claro que visto por um outro ângulo é um cumprir entre aspas, pois, ao se contrapor o texto visual do cartaz com a mensagem ideológica do prólogo, o que resulta é uma paródia da "cor cubana", a negação da profecia tal como anunciada por tinta da personagem destoa "mulata" de seus versos e "cor cubana". A cor negra realudido pelos qualificativos 
"mulato" e "mestiço". De fato, através do cartaz fica claríssimo que a imagem que atualmente expressa a "cor cubana" é a da mulher negra e não mulata, imagem que, indubitavelmente, coloca-se no contrafluxo dessa outra auto-imagem nacional, na qual a cor negra da nossa cultura é percebida mais como uma cor espiritual que física, que faz com que Cuba, assim como o Brasil, seja também um país "lindo e trigueiro" em "corpo e alma'".

Por outro lado, chama também a atenção a imagem fotográfica de um casal de meninos com evidentes traços caucasóides, imagem esta aparentemente superposta, mas que na realidade faz parte do tecido da camiseta que veste a mulher negra (cubana). Esta imagem pode ser lida ideologicamente como uma referência à mestiçagem biológica afro-hispânica celebrada por Guillén através da metáfora dos continentes que, se bem separados na superfície, estão secreta e espiritualmente unidos na profundidade dos oceanos.

A meu ver, as considerações acima mostram até que ponto os deslocamentos retóricos, tanto no âmbito da escrita como nos textos visuais, mudam e permanecem, alteram e reiteram, articulam e desarticulam e, sobretudo, resignificam os discursos culturais e seus ideologemas fundantes.

Esta discussão poderia continuar ad infinitum. Retorno, contudo, à questão que suscitou inicialmente as reflexões aqui contidas. Considero que a suposta ruptura epistemológica que se cristaliza na década de 30 representa um deslocamento dentro do discurso da mestiçagem na América Latina, e não uma mudança de discurso. Este deslocamento, se bem que retórico, teve um impacto conceitual significativo na fenomenologia das relações raciais e étnicas nos diversos países do continente e em suas ilhas, se bem que sua ontologia, em outras palavras, seus princípios norteadores, sua estrutura básica, sua poética, tenham permanecidos congelados nas rígidas hierarquias sociais que tornam possíveis a percepção fluida dessas relações. Não obstante, tal deslocamento retórico tem marcado e contribuído para mudar conceitualmente o discurso da identidade (cultural, nacional, regional) na América Latina até os dias atuais.

\section{AGRADECIMENTOS}

A pesquisa que resultou neste trabalho foi realizada durante minha estadia no Centro Interdisciplinar de Estudos Contemporâneos (CIEC) da Escola de Comunicação da Universidade Federal do Rio de Janeiro, primeiro como bolsista da Rockfeller Foundation e depois como pesquisadora associada com o apoio do Social Science Research Council. Gostaria de agradecer à professora Ilana Strozenberg, coordenadora do CIEC, pelo estímulo intelectual e pelas inúmeras conversas sobre o meu trabalho. Sou grata ao pesquisador Lívio Sansone por ter cedido o lindo cartaz da exposição Color Cubano, aqui reproduzido. Ao meu amigo e colega, Antonio Sergio Guimarães, professor do Departamento de Sociologia da Universidade Federal da Bahia, agradeço pela leitura da primeira versão do manuscrito. Sobretudo, quero expressar meus agradecimentos aos editores desta coletânea, Marcos Chor Maio e Ricardo Ventura Santos, ótimos interlocutores, pelas suas generosas e perspicazes leituras do manuscrito. 


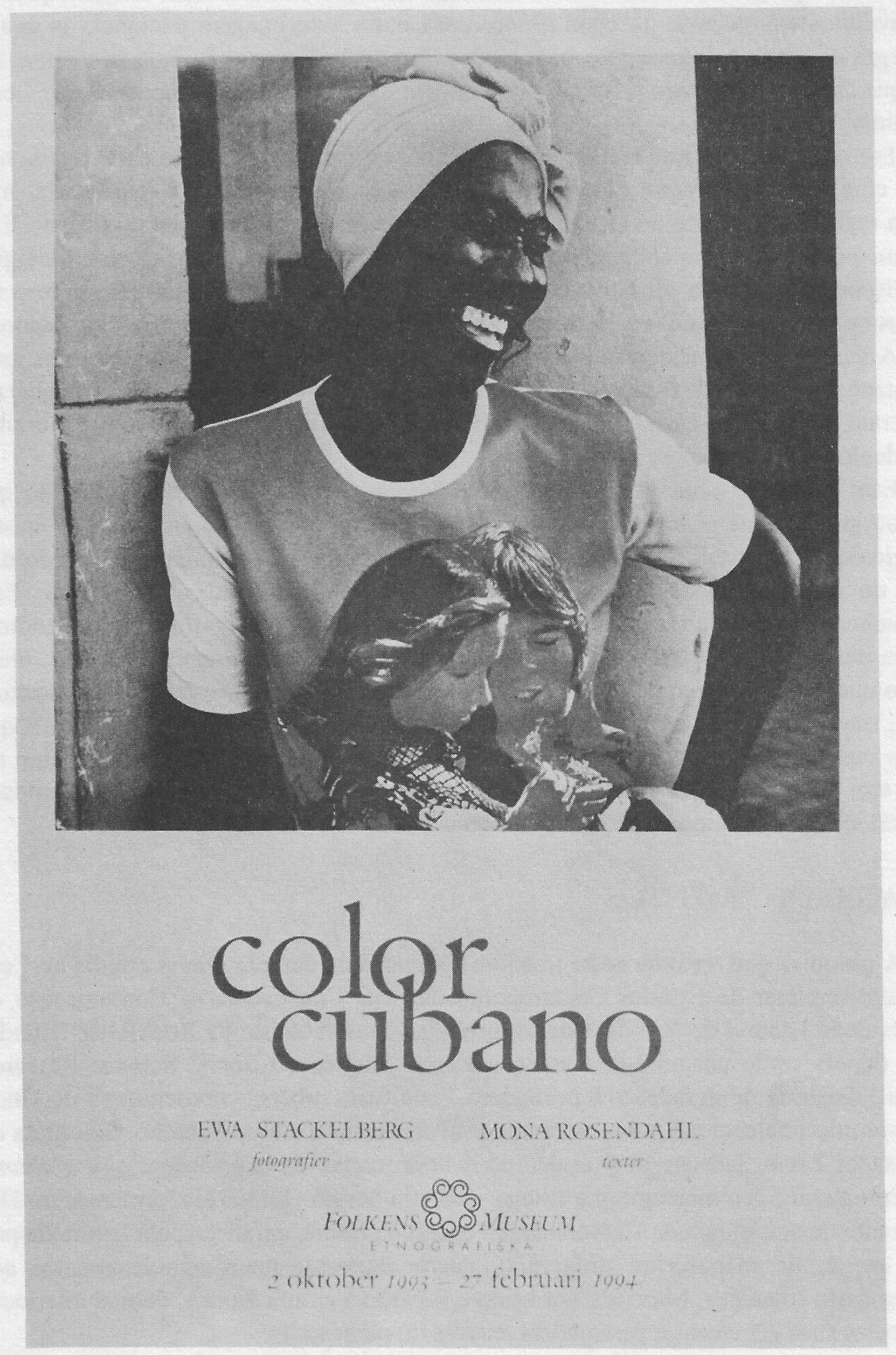

Cartaz da exposição fotográfica Color Cubano, patrocinada pelo Folkens Museum de Estocolmo (reproduzido com permissão). 


\section{REFERÊNCIAS BIBLIOGRÁFICAS}

AMADO, J., 1977. Mar Morto. La Habana: Editorial Arte y Literatura.

AMADO, J., 1978. Jubiabá. La Habana: Editorial Arte y Literatura.

AMADO, J., 1980. Capitães de Areia. Rio de Janeiro: Record.

ANDRADE, O., 1972. Manifesto antropófago. Obras Completas. Vol VI. Rio de Janeiro: Civilização Brasileira.

ARAÚJO, R. B., 1994. Guerra \& Paz. Casa-Grande e Senzala e a Obra de Gilberto Freyre nos anos 30. Rio de Janeiro: Editora 34.

BENITEZ ROJO, A., 1989. La Isla que se Repite: El Caribe y la Perspectiva Posmoderna. Hanover: Ediciones del Norte.

BROOKSHAW, D., 1983. Raça e Cor na Literatura Brasileira. Porto Alegre: Mercado Aberto.

CÂNDIDO, A., 1963. O Método Crítico de Silvio Romero. Boletim 266, Faculdade de Filosofia, Ciências e Letras, Universidade de São Paulo.

CARPENTIER, A., 1971. El Reino de este Mundo. 1949. México: Conpañia General de Ediciones.

CHIAMPI, I., 1980. O Realismo Maravilhoso. São Paulo: Perspectiva.

FREYRE, G., 1936. Sobrados e Mucambos. Rio de Janeiro: Companhia Editora Nacional.

FREYRE, G., 1955. Manifesto Regionalista de 1926. Rio de Janeiro: Ministério de Educação e Cultura.

FREYRE, G., 1957. Casa-Grande \& Senzala. Lisboa: Colecção Livro do Brasil.

FREYRE, G., 1963. New World in the Tropics. The Culture of Modern Brazil. New York: Vintage Books.

GoldBerG, D. T., 1993. Racist Culture. Philosophy and the Politics of Meaning. Massachusetts: Blackwell.

GUILLÉN, N., 1981. Songoro Cosongo. Poemas Mulatos. México: Presencia Lationamericana.

GUIMARÃES, A. S., 1994. Racismo e anti-racismo no Brasil. Resumos do XVIII Encontro Anual da Anpocs. Caxambu, MG

IANNI, O., 1993. O Labirinto Latinoamericano. Petrópolis: Vozes.

MARTÍNEZ-ECHAZÁBAL, L., 1984. La Ideología de la Mulatez y su Expresión Literaria en Tres Novelas Hispanoamericanas: 1928-1950. Diss. University of California, San Diego.

MARTÍNEZ-ECHAZÁBAL, L., 1988. Positivismo y racismo en el ensayo hispanoamericano. Cuadernos Americanos, 3:121-129.

MARTÍNEZ-ECHAZÁBAL, L., 1990a. Para una Semiótica de la Mulatez. Madrid: Porrúa Turanza.

MARTÍNEZ-ECHAZÁBAL, L., 1990b. From Racialism to Culturalism in Latin American Writings. Trabalho apresentado na Universidade de Califórnia, Santa Cruz. 
MARTÍNEZ-ECHAZÁBAL, L., 1992. Racial Identity and Nation. Resumos do XVII Encontro da $L A S A$. Los Angeles.

MARTÍNEZ-ECHAZÁBAL, L., 1996. From race to culture: the displacement of racist discourse within Latin American writings. In: Race, Culture and National Identity in the AfroAmerican Diaspora (Helen Safa, ed.), no prelo. NINA RODRIGUES, R., 1935. O Animismo Fetichista dos Negros Bahianos. (1896). Rio de
Janeiro: Civilização Brasileira. NINA RODRIGUES, R., 1939. As Collectividades Anormaes. Rio de Janeiro: Civilização
Brasileira.

NINA RODRIGUES, R., 1938. As Raças Humanas e a Responsabilidade Penal no Brasil. 1894. São Paulo: Companhia Editora Nacional.

ORTIZ, F., 1978. Del fenómeno de la transculturación y sus importancia en Cuba. Contrapunteo Cubano del Tabaco y el Azúcar. Caracas: Biblioteca Ayacucho.

ORTIZ, R., 1983. Cultura Brasileira e Identidade Nacional. São Paulo: Brasiliense.

ORTIZ, F., 1993. Martí y las razas. Etnia y Sociedad. La Habana: Letras Cubanas. RAMOS, A., 1939. As Collectividades Anormaes. Por Raimundo Nina Rodrigues. Rio de Ja-
neiro: Civilização Brasileira. RIBEIRO, D., 1995. O Povo Brasileiro. A Formação e o Sentido do Brasil. São Paulo: Com-
panhia das Letras.

ROMERO, S., 1980. História da Literatura Brasileira. 1888. Rio de Janeiro: J. Olympio. SACRAMENTO BLAKE, A. V. A., 1969. Diccionário Bibliographico Brasileiro: 1883-
1902. Vol. 7. Nendeln: Kraus Reprint.

SCHWARCZ, L. M., 1993. O Espetáculo das Raças. São Paulo: Companhia das Letras. SCHWARTZ, J., 1995. Vanguardas Latino-Americanas. São Paulo: Editora da Universidade
de São Paulo.

STOLCKE, V., 1991. Sexo es para gênero assim como raça para etnicidade? Estudos Afro-
Asiáticos, 20:101-119.

VASCONCELOS, J., 1982. La Raza Cósmica. 1925. México: Espasa Calpe.

VENTURA, R., 1991. O Estilo Tropical. História Cultural e Polêmicas Literárias no Brasil.

São Paulo: Companhia das Letras.

VENTURA, R., 1994. Democracia racial e multiculturalismo. Trabalho apresentado na Conferência Sinais de Turbulência, Rio de Janeiro.

VIANNA, O., 1923. Evolução do Povo Brasileiro. São Paulo: Monteiro Lobato \& Co.

VALENTE, W., 1977. Sincretismo Religioso Afro-Brasileiro. 1955. São Paulo: Companhia

WRIGHT, W. R., 1990. Café con Leche. Race, Class, and National Image in Venezuela. Austin: The University of Texas Press. 


\title{
7 DA MORFOLOGIA ÀS MOLÉCULAS, DE RAÇA À POPULAÇÃO: TRAJETÓRIAS CONCEITUAIS EM ANTROPOLOGIA FÍSICA NO SÉCULO XX
}

\author{
Ricardo Ventura Santos
}

\section{INTRODUÇÃO}

O objetivo deste trabalho é analisar a trajetória do conceito de "raça" em um campo específico da reflexão antropológica, qual seja, a antropologia física (ou antropologia biológica). "Raça" e modelos tipológicos derivados, muito populares nesta disciplina no século XIX, experimentaram crescente crítica e reformulação a partir de então. Analogamente a outros campos da antropologia, na qual se processou uma transição de "raça" a "cultura", "raça" também se tornou um conceito gradativamente menos proeminente em antropologia física. Contudo, a noção emergente não foi "cultura", mas "população", que penetrou na antropologia física a partir da biologia (evolucionária). Argumenta-se também neste ensaio que a transição não foi abrupta; paralelamente a uma crescente insatisfação com "raça", foi gestada uma "híbrida e singular", articulação teórica através da qual o conceito foi perdendo sua conotação tipológica/descritiva e assumindo tons evolutivos, aproximando-se de "população", com sua ênfase em variabilidade e dinamismo. Portanto, sendo um conceito caro à disciplina e que de certa forma encapsulava sua própria identidade, "raça" não foi abandonada, mas moldada para se adequar ao evolucionismo neodarwiniano que reformulou a antropologia física a partir de meados deste século.

Este trabalho está dividido em duas partes. Na primeira é analisado o contexto histórico e teórico da transição de "raça" a "população". Argumenta-se que os debates em torno dos "Estatutos sobre Raça" da UNESCO na década de 50 marcam um momento especial deste processo, quando a questão transpôs círculos acadêmicos mais estritos e alcançou o status de tema de interesse público. Isto está associado ao clima do pós-guerra, em particular ante a constatação das conseqüências da política implementada pelos nazistas que, como bem sabido, baseava-se num modelo racializado. Na segunda parte do texto discute-se a utilização do conceito de "raça" na antropologia física brasileira a partir da década de 50 . Veremos que, enquanto algumas linhas de investigação operaram (e continuam a operar) com o conceito à luz do neodarwinismo, em outras persistiu uma abordagem essencialmente tipológica para a questão da variabilidade biológica humana.

1 Esta expressão foi utilizada por Araújo (1994) em sua análise acerca da transição de "raça" a "cultura", na obra de Gilberto Freyre. Retornarei a este ponto no final do trabalho. 


\section{DA MORFOLOGIA ÀS MOLÉCULAS, DE RAÇA À POPULAÇÃO}

A Origem das Espécies, obra seminal de Charles Darwin e cuja primeira edição data de 1859, é tida como um marco de uma corrente intelectual (darwinismo) cuja influência nos mais diversos campos do conhecimento - biologia, medicina, história, antropologia - foi extremamente expressiva. Darwin postulou uma teoria de evolução biológica segundo a qual todas as espécies descendem de um ancestral comum e evoluem gradativamente através do processo de seleção natural. O conjunto de trabalhos de Darwin e de outros evolucionistas na segunda metade do século XIX compõe o que Mayr (1982) denomina de "primeira revolução darwiniana". A aceitação do darwinismo enquanto teoria explicativa do processo de evolução biológica não aconteceu de forma imediata e/ou unânime, como apresentado nos livros didáticos. Pelo contrário, o darwinismo só veio a se consolidar décadas após a morte de Darwin. Inclusive, segundo Bowler (1989), as últimas décadas do século XIX foram de "eclipse" para o darwinismo, tal foi a influência de outras teorias (neolamarckismo, ortogênese, entre outras), algumas delas antidarwinianas, que também buscavam explicar o processo evolutivo (vide
também Stocking, 1968).

O darwinismo só veio a se estabelecer como paradigma de ampla aceitação na biologia moderna nos anos 40, o que corresponde à chamada "segunda revolução darwiniana" (Mayr, 1982). Os conhecimentos acumulados até então levaram à elaboração de um esquema explicativo - a chamada "síntese evolucionária ou neodarwiniana" - aplicável aos diversos níveis do processo evolutivo. Através dela procurou-se explicar desde a transmissão do material genético até a origem de novas espécies. Até então, biólogos experimentais e naturalistas trabalhavam em isolamento teórico uns dos outros, apesar do interesse em comum pela evolução biológica. A "síntese" possibilitou compatibilizar mendelianismo (que explicava a transmissão dos caracteres hereditários), biometria (que abordava o comportamento dos genes e características morfológicas das populações) e darwinismo (que tratava da origem e evolução das espécies). O paradigma evolutivo que persiste em biologia no presente deriva, com algumas modificações, da referida
"síntese"' (vide Mayr, 1982; Bowler, 1989).

Por certo o evolucionismo já exercia uma profunda influência nas teorias em antropologia física na segunda metade do século XIX. Os debates sobre monogênese e poligênese, por exemplo, apesar de freqüentemente embasados em teses tipológico-descritivas, eram informados por modelos evolucionistas, ainda que não necessariamente darwinianos. ${ }^{2}$ Segundo alguns autores, contudo, o darwinismo, com sua ênfase em mudança, instabilidade, transformação, trouxe dificuldades adicionais para ês teorias raciológicas com modelos evolucionistas, a expansão do darwinismo tornou esta associação progres-

O pensamento evolucionista não emerge com Darwin (Mayr, 1982; Bowler, 1989). Eram comuns modelos evolucionistas na ciência européia no período anterior à emergência do darwinismo na segunda metativas pré-Darwin. 
os antropólogos fisicos estavam comprometidos com uma ciência cuja essência enfatizava a fixidez e estabilidade, com 'tipos' raciais cuja realidade e permanência permitiam estabelecer classificações raciais categóricas de grupos humanos [...] A evolução, por outro lado, era uma teoria de mudança contínua, em principio profundamente contrária ao pensamento tipológico e essencialista. (Stepan, 1982:84)

Ao longo da primeira metade do século $\mathrm{XX}$, a maioria dos antropólogos físicos continuava a operar com os conceitos de "raça" e de "tipo racial". Associados majoritariamente à medicina e à anatomia, mantinham-se fiéis aos estudos morfo-anatômicos descritivos, ${ }^{4}$ permanecendo marginais às discussões em biologia experimental e comportamental que vieram a alimentar teoricamente a síntese neodarwiniana. Tampouco foram sensibilizados pelos argumentos de autores como Franz Boas, que criticavam a idéia de estabilidade e fixidez das características raciais. Em uma série de trabalhos clássicos, com títulos como Changes in Immigrant Body Form (1908) e Instability of Human Types (1912), Boas reportou os resultados de seus estudos sobre crescimento físico de crianças filhas de migrantes, demonstrando que marcadores raciais clássicos, como o índice cefálico, não eram fixos ou estáveis, como sugeriam os antropólogos físicos; pelo contrário, podiam ser profundamente influenciados pelas condições ambientais (Boas,
1940; Stocking, 1968).

Analisando a trajetória do conceito de "raça", George Armelagos (1992:1) afirmou recentemente: "...tal como o camaleão que muda sua cor para mimetizar um ambiente em mudança, o conceito de 'raça' foi sendo transformado para se adequar a um clima intelectual em transformação". A metáfora zoológica de Armelagos aplica-se perfeitamente ao que veio a acontecer com "raça" em antropologia física com a expansão do neodarwinismo e florescimento da biologia experimental nas primeiras décadas deste século. Por um lado, tornava-se cada vez mais evidente que as tipologias raciais implementadas com base em características morfodescritivas careciam de bases biológicas sóparâmetros biológicos trouxe umalar as classificações raciais, a descoberta de novos Em 1900-1901, trouxe uma revitalização dos debates sobre "raça",

teiner, a cuja descoberta seguiram-se outras. Pesquisas em genética, por sua riam que estas eram características que se transmitiam através de modica, por sua vez, sugeestavam presentes em todas as populações humanas e mais de modelos mendelianos, influências de condições ambientais. A antiguidade e, mais importante, não sofriam as trada através de sua ocorrência em primatas não humanos, o que reforçava a doi demonsdestes marcadores no estudo da história biológica da espécies, o que reforçava a utilidade te à origem das várias "raças", (Armelagos, güíneos fossem implementados como marcadores raciais, iniciando que os grupos sanparâmetros morfológicos para um segundo plano. No seu influente Genetics and the Ra-

Todas as traduções de passagens em língua estrangeira ao longo do texto são minhas.

Tanto em teoria como em método a antropologia física pouco lidava com variabilidade. Os próprios propedimentos estatísticos, com grande ênfase em parâmetros de tendência central (média, mediana etc.) e pouca em medidas de dispersão (desvio-padrão, variância etc.), reforçavam a noção de "tipo". Ales Hrdlicka, um influente antropólogo físico da primeira metade deste século, teria afirmado que "a estatís-
tica será a ruína da antropologia física"' (apud Trinkaus \& Shipman, 1992:217). 
ces of Man, Willian Boyd (1950) argumentou que as classificações raciais deveriam ser baseadas em características de herdabilidade conhecida. Criticando a utilização da morfologia, que no passado havia constituído o cerne das classificações mas que neste momento já era percebida como potencialmente influenciável por fatores ambientais, Boyd apontava para as vantagens dos marcadores sangüíneos: respondiam às leis da herança mendeliana, eram matematicamente manipuláveis e de determinação "objetiva", assim como livres de influências ambientais (apud Armelagos, 1992:9-10).

A descoberta de um,crescente número de parâmetros bioquímicos a partir do início deste século marca o início de um mergulho da antropologia física em direção a partes cada vez mais recônditas do corpo humano. Foi algo como uma "migração" metodológica da superfície do corpo - já não eram tão relevantes características como cor de pele, tipo de cabelo, formato de nariz, dimensões craniométricas - em direção a estruturas cada vez menores e não mais acessíveis macroscopicamente. Os marcadores raciais foram redefinidos de modo a acompanhar este deslocamento metodológico desde a morfologia às moléculas. ${ }^{5}$ É bem verdade que a síntese neodarwiniana e os avanços metodológicos da biologia experimental transformaram a utilização do conceito enquanto ferramenta de classificação. Não obstante, a "molecularização" metodológica não se fez acompanhar de uma "desracialização" conceitual. "Raça" saiu da esfera de influência da perspectiva tipológico-descritiva para se tornar um conceito abrigado à sombra da genética, tendo sido gradativamente moldada para se tornar próxima de "população", o conceito emergente e chancelado pela síntese neodarwiniana. A maneira como dois influentes antropólogos físicos norte-americanos definiram "raça" ao longo deste século
mostra este ponto claramente:

'Raça' é uma divisão fisica da humanidade, cujos membros se distinguem por possuirem uma combinação similar de caracteristicas anatomicas devido a uma hereditariedade comum [...] Não existe um critério fisico único para distinguir as plas variações no foro delimitadas pela associação nos grupos humanos de múltino cabelo, na pele e nos olhos, tipo de cabelo, tal como a quantidade de pigmento tura; relação entre cos olhos; tipo de cabelo; formato do nariz; variação em esta-

Já em Human Races, originalmente publicado em 1961, Garn (1971) assim definiu "raça"': "... a perspectiva contemporânea para raça deriva da genética de populações, na qual raça é vista como uma população em isolamento reprodutivo, nem mais, nem me-
nos" (Garn, 1971:5).

Portanto, ao longo do tempo "raça" foi se transformando, assumindo contornos que a aproximaram de conceitos emergentes na genética de populações a partir da síntese neodarwiniana. Houve um processo de "hibridação", através do qual perspectivas apa-

\footnotetext{
Em um ensaio recente, intitulado Ghosts of Bell Curves Past, Stephen Jay Gould (1995) analisou o re(Charles Murray e Richard Herrnstein) Curve. Entre outros aspectos, afirma que as idéias dos autores Essai sur l'inégalite des Races Humaines, por vezes semelhantes àquelas do Conde de Gobineau em seu século XIX. Em dado momento de seu ensaio, Gouldo como uma das expressões do racismo científico do estruturas das idéias podem ser tão similares através (1995:16) diz-se fascinado com o fato de como as temáticas afins enfatizem diferentes partes de uma entidade, a depender dos recursos técnicos disponí-
veis.
} 
rentemente antagônicas e irreconciliáveis foram aproximadas. A meu ver, isto resolve o "enigma" colocado por Stocking (1968) e Stepan (1982), de como a antropologia física lidou com o conceito de "raça". Partindo de uma perspectiva cuja ênfase residia em categorias fixas e estáticas, "raça" foi sendo redefinida de modo a efetivar uma conciliação com um evolucionismo cuja ênfase era em dinamismo e mudança. ${ }^{6}$

Isto não quer dizer, contudo, que o processo tenha se desenrolado de maneira suave, consensual e sem contratempos. Mesmo em meados deste século, já no pós-guerra, certos segmentos da antropologia física ainda não estavam dispostos a abrir mão de uma versão tipológica, descritiva e determinista de "raça". Este é o tópico da próxima seção, que trata das "Declarações sobre Raça" elaboradas sob o patrocínio da UNESCO na década de 50 .

\section{DECLARAÇÕES DA UNESCO: POLÍTICA, RAÇA E POPULAÇÃO}

Em 1949, a assembléia geral da UNESCO (United Nations Educational, Scientific and Cultural Organization) decidiu convocar especialistas para debater o conceito de "raça" visando, entre outros objetivos, estudar, coletar e difundir material científico, bem como preparar uma campanha educacional a partir destas informações (UNESCO, 1952:6).

Coube ao brasileiro Artur Ramos organizar a primeira reunião, da qual ele não chegou a participar por ter falecido alguns dias antes de sua realização. Entre os participantes, e cujos nomes são bem conhecidos no presente, estavam Claude Lévi-Strauss, Juan Comas e L. A. Costa Pinto. Apesar de não participarem do comitê, os biólogos evolucionistas Julian Huxley e Theodosius Dobzhansky estavam entre os que fizeram sugestões acerca do conteúdo do documento antes de sua divulgação. A tarefa de relator coube ao antropólogo Ashley Montagu, que havia estudado sob a orientação de Franz Boas e com ele compartilhava uma posição bastante crítica acerca do valor heurístico de "raça" (Boas, 1940). Montagu já era um escritor conhecido nesta época, uma vez que havia publicado inúmeros livros, incluindo Man's Most Dangerous Myth: The Fallacy of Race (1942), atacando o conceito de "raça" e as ideologias racistas.

A chamada "Primeira Declaração sobre Raça" foi tornada pública em julho de 1950. Alguns de seus principais pontos são os seguintes: (1) enfatiza que as diferenças biológicas entre grupos humanos são devidas à operação de forças evolutivas e que a espécie humana é constituída por "populações", na dimensão neodarwiniana do termo; (2) "raça" designa um grupo ou população que se caracteriza por concentração de partículas hereditárias (genes) ou atributos físicos, que podem variar ao longo do tempo; (3) a história humana e estudos biológicos demonstram que o espírito cooperativo é natural e arraigado nos seres humanos (ou seja, o ódio racial não lhes seria uma característica intrínseca, "natural"); (4) os grupos humanos não diferem em suas características mentais inatas, seja inteligência ou comportamento (UNESCO, 1952).

Esta aproximação entre antropologia física e darwinismo pós-síntese resultou na "nova antropologia física", ou antropologia biológica. Um dos mais influentes agentes desta mudança foi o paleontólogo e primatologista $\mathrm{S}$. Washburn, que no final dos anos 40 iniciou uma estreita colaboração com geneticistas como T. Dobzhansky, que foi um dos "arquitetos" na síntese neodarwiniana nos anos 40 (vide Haraway, 1989:186-230). 
O texto da "Primeira Declaração" é peculiar: nele mesclam-se idéias oriundas da tradição antropológica boasiana - para Proctor (1988:174) o documento da UNESCO representou o triunfo da antropologia boasiana - com postulados genéticos associados à síntese neodarwiniana. Esta associação produziu um documento no qual "raça" é colocado como um conceito secundário a "população" ("Homo sapiens é constituído por diversas populações"), como dificilmente operacionalizável ("as raças humanas podem e têm sido classificadas de modo diferente por diferentes antropólogos"), como biologicamente vazio (" "raça' não é tanto um fenômeno biológico como um mito social") e de pouca influência sobre os atributos mentais ("grupos humanos não diferem em suas características mentais inatas") (UNESCO, 1952:98-103). Marcando a influência da teoria evolutiva, foi incluído no texto da "Primeira Declaração" um trecho do livro de Darwin, The Descent of Man and Selection in Relation to Sex, no qual mesclam-se evolucionismo com espírito cooperativo e tolerância social:

à medida que o homem avança em seu processo civilizatório, e pequenas tribos são unidas em comunidades maiores, a razão [...] diria a cada indivíduo que se deve estender seus instintos sociais e simpatias para todos os membros de sua própria nação, ainda que pessoalmente desconhecidos para ele. (UNESCO, 1952:101-102)

A articulação entre a tradição antropológica boasiana (com sua crítica ao determinismo racial) e o neodarwinismo (com sua proposta de "população" enquanto unidade básica de análise), visando um posicionamento integrado acerca de "raça", pode soar um tanto inesperada. Não tanto pela primeira que, como vimos, logo na virada do século lançou dúvidas acerca dos fundamentos das tipologias raciais (Boas, 1940; Stocking, 1968). Já a genética, ou pelo menos uma parcela de seus praticantes, teve um íntimo envolvimento com o movimento eugênico (Stocking, 1968; Provine, 1973; Stepan, 1982; Bowler, 1989). Ou seja, se antes da Segunda Guerra algumas versões do darwinismo, assim como outras doutrinas da biologia evolucionária, estiveram diretamente associadas à produção de uma ciência autoritária e racista, aparentemente emerge no pós-guerra uma biologia - ou pelo menos um grupo de pesquisadores - que advogava um "homem universal e biologicamente equipado para igualdade e direito à plena cidadania" (Haraway, 1989:197-203). Autores como Haraway (1989) e Greene (1990) traçam o "humanismo evolucionário" que permeia a "Primeira Declaração" não a uma transformação conceitual em biologia, mas a idéias de um certo grupo de biólogos, incluindo Theodosius Dobzhansky e Julian Huxley, que também haviam participado do processo de elaboração da "síntese neodarwiniana". Para estes evolucionistas era possível articular biologia evolucionária e humanismo - como se depreende do texto da "Primeira Declaração" visando estimular entre os seres humanos cooperação, dignidade, controle da agressão e progresso (Greene, 1990).

Reações à "Primeira Declaração" não tardaram. Logo após ter sido tornada pública, o editor (o etnólogo Willian Fagg) do periódico britânico Man publicou-a na íntegra e convidou um grupo de antropólogos físicos e geneticistas para comentar seu conteúdo. A presença do mexicano Juan Comas no primeiro comitê não foi suficiente para convencer os demais que a disciplina havia sido representada. As cartas endereçadas a Man vão desde aquelas em tom conciliatório (Fleure, 1951; Little, 1951) até outras nem tanto (Hill, 1951; Vallois, 1951), nas quais não somente idéias, como pessoas, eram diretamente atacadas. Em linhas gerais, as críticas direcionam-se a três aspectos: (1) o docu- 
mento não fazia a devida distinção entre "raça" enquanto um conceito biológico e en-
quanto um conceito social, além de anular a primeira dimenão; rido no texto, não seria um fato cientificamente comprovado que (2) ao contrário do sugeraciais quanto às capacidades mentais; (3) seria infundado que não haveria diferenças biológicos indicariam que os seres humanos nascem destina a afirmação de que estudos versal (UNESCO, 1952:7). Defendendo a validade de "estinados a uma fraternidade unica, a percepção de muitos antropólogos físicos foi 'raça' enquanto categoria biológi"Primeira Declaração". Para alguns, ela apresentava claramente antagônica ao texto da vamente categóricas e negações mal justificadas'" (Vallontradições, afirmações "excessiafirmações estavam mais próximas de doutrinas filosols, 1951:16); para outros, certas idéias "cientificamente modernas" (Little, 1951:17) ram que as conclusões refletiam tão somente as opiniões também aqueles que afirmaantropólogos, cujas assertivas pareciam ser guiadas mais por "boa intencão" "fatos científicos estabelecidos" (Hill, 1951:16). A propósito, o autor desão" do que por mentário - o primatologista britânico W. C. Osman Hill sósito, o autor deste último comente as idéias e proponentes da "Primeira Declaração", não somente atacou causticameias-palavras em seus comentários sobre "raça" e tempero", como também não empregou

Que a variação em capacidade mental é 'mais ou menos' a mesma em todas as
aças é dificilmente uma afirmação cientifica acurada É no máximo uma generairaças é dificilmente uma afirmação cientifica acurada. É no máximo uma generalise com diferenças fisicas. Basta mencionar os bem conhecidos atributos melacionamnegróides e as habilidades matemáticas de algumas raças indianas atributos musicais dos

Por fim, é interessante mencionar que os criţcos indianas. (Hill, 1951:16-17) intermédio de C. D. Darlington, também que os críticos da "Primeira Declaração", por de uma passagem de The Descent of Man and enfatizar a existência de diferenças entre as raças:

principalmente no que tange a suas faculdades mentais, mas também bastante distintas,

quanto a suas faculdades intelectuais. (apud UNESCO 1952:27)

No ano seguinte à troca

UNESCO convocounte à troca de correspondências (e ofensas) nas páginas de Man, a seguinte:

Raça é uma questão de interesse para muitos tipos diferentes de pessoas, não somente para o público em geral, mas para sociólogos, antropólogos e biólogos, especialmente para aqueles lidando com problemas de genética. Na primeira discussão que formularam a Declaração [...] $O$ docume sociólogos que emitiram suas opiniões e gava a autoridade daqueles grupos no âmbito dos quis bom efeito, mas não carreca de raça, ou seja, antropólogos fisicos e geneticistas situa a dimensão biológiDeclaração não traduzia em todos fisicos e geneticistas. Além disso, a primeira do a isso, não apoiaram em todos os detalhes, a conviç̧ão destes grupos que, devi-

A segunda reunião aconteceu emocumento. (Dunn, 1951:155)

físicos e geneticistas. Do ponto de em 1951 e dela participaram somente antropólogos pólogo-físico francês $H$. Vallois (uista político, foi cuidadosamente organizada: o antro- 
do como presidente do comitê e ao geneticista norte-americano L. C. Dunn coube o estratégico cargo de relator. Ligado pessoalmente a Dobzhansky e teoricamente à síntese neodarwiniana, Dunn já havia participado da revisão do texto da "Primeira Declaração". Inicialmente não convidado, Montagu foi posteriormente incluído no comitê como representante do grupo que havia redigido o primeiro texto.

Quais as diferenças entre os dois documentos? Para o próprio Dunn, as principais conclusões da "Primeira Declaração" foram mantidas "com poucas diferenças de ênfase e algumas importantes eliminações" (Dunn, 1951:155). Na verdade, o texto da "Segunda Declaração" é mais biológico e factual, e contém menos observações de cunho fílosófico, além de menos enfática no tocante ao "determinismo cultural" (vide Barkan, 1992:342-343). Ainda que "raça"' tenha sido recolocado como um conceito biologicamente válido, o foi somente à luz da genética: "o conceito de raça é unanimemente considerado pelos antropólogos como uma ferramenta de classificação através da qual estudos sobre o processo evolucionário podem ser realizados"' (UNESCO, 1952:11). No tocante à inteligência, temperamento, cultura e "raça", os membros do comitê optaram por um posicionamento inconclusivo, afirmando que os dados disponíveis não permitiam comprovar ou rechaçar a existência de associações. Parafraseando Haraway (1989:197203), pode-se afirmar que o ser humano que emerge na "Segunda Declaração" é, "ainda que universal, biologicamente menos equipado para igualdade e direito à plena cidadania'. Não obstante, biologicamente limitado ou não, o ser humano delineado no documento dos geneticistas e antropólogos físicos não é definido a partir de modelos tipológicos e racializados, mas à luz do neodarwinismo.

\section{"RAÇA" NA ANTROPOLOGIA FÍSICA CONTEMPORÂNEA}

Da discussão acima fica evidente que os debates em torno dos documentos da UNESCO representaram o acirramento de posicionamentos prévios de grupos que defendiam visões distintas acerca de "raça". Quais foram os desdobramentos deste processo? Na segunda metade do século XX efetivou-se em antropologia física uma transição de "raça" a "população", a exemplo do realinhamento de "raça" a "cultura" em outros campos da antropologia algumas décadas antes? Esta dinâmica também ocorreu no Brasil e, se afirmativo, como se compara ao exemplo de outros países?

É nos E.U.A. onde se encontra a maior e mais ativa comunidade de antropólogos físicos. Solidamente estabelecida do ponto de vista acadêmico, está presente nos departamentos de antropologia das principais universidades. A despeito de sua proeminência teórico-metodológica, aliada ao fato de que foi notadamente por influência de antropólogos e geneticistas ligados a instituições norte-americanas que se consolidou a crítica a "raça", alguns autores argumentam que o conceito em sua vertente "tipológica" ainda se faz bastante presente na antropologia física norte-americana (Armelagos, 1992; Goodman, 1995). Em uma recente análise, Goodman (1995) chama atenção para o que denomina "esquizofrenia do conhecimento", ou seja, ainda que a noção de "raça", seja percebida como teoricamente ultrapassada pela maioria dos antropólogos físicos, ainda é freqüentemente utilizada por uma parcela deles. Goodman ressalta ainda que a aderência a "raça" varia segundo a especialidade, sendo mais comum naquelas áreas mais ligadas à anatomia e morfologia (como a análise de material esqueletal, 
que já constituiu o cerne da disciplina) e menos freqüente naquelas mais próximas da genética de populações. ${ }^{7}$ A seguir veremos que a trajetória do conceito de "raça" na antropologia física no Brasil a partir da década de 50 indica paralelos com o quadro delineado por Goodman (1995).

Até os anos 30/40 a antropologia física ocupava um posição de destaque no cenário antropológico brasileiro. Diversos autores têm apontado para sua proeminência no contexto das ciências médicas e sociais no Brasil na virada do século, quando estava representada nas principais instituições de pesquisa do País, como o Museu Nacional, o Museu Paulista e o Museu Emílio Goeldi, bem como em Faculdades de Medicina (Castro-Faria, 1952; Corrêa, 1982; Seyferth, 1985; Schwarcz, 1993; entre outros). O eclipse experimentado pela disciplina a partir de então, em particular no âmbito dos museus de história natural, associa-se a uma tendência teórica mais ampla em antropologia, na qual modelos raciais/biológicos, que haviam dominado o campo no século XIX, foram gradativamente suplantados por análises centradas em "cultura" e "sociedade" 8 O fato é que a antropologia física fez-se presente no Brasil entre as décadas de 50 e 80 através principalmente de duas linhas de investigação, que se mostraram dissociadas tanto institucional como teórica e metodologicamente. A primeira caracteriza-se pela continuidade, podendo ser exemplificada por investigações realizadas no Museu Nacional, Rio de Janeiro, cuja produção no período enfocou a análise osteométrica (medição de ossos) de remanescentes humanos de origem arqueológica. ${ }^{9}$ A segunda linha de trabalho consolidou-se no pós-guerra no âmbito de departamentos de biologia e/ou genética de algumas universidades (Universidade de São Paulo e Federais do Rio Gande do Sul, Bahia, Pará, entre outras), portanto, externamente a departamentos de antropologia e museus de história natural. Centra-se na genética de populações e caracteriza-se pela independência em relação a tradições em antropologia física existentes anteriormente no Brasil. ${ }^{10} \mathrm{O}$ tratamento dispensado a "raça" por estas duas linhas foi marcadamente distinto, ainda que certos paralelismos possam ser identificados.

7 Goodman (1995) apresenta a questão da persistência de "raça" em antropologia biológica como um problema de (in)consistência teórica interna à disciplina. Infelizmente seu texto aborda superficialmente a questão de como os modelos racializados da antropologia física norte-americana contemporânea refletem a própria visão de mundo da sociedade onde estes cientistas estão inseridos, na qual "raça" é uma categoria de profunda significância na dinâmica social.

8 A literatura acerca desta temática é vasta. Stocking (1968) provê um panorama histórico a respeito desta transição. Para o caso brasileiro, vide Corrêa (1982), Araújo (1994), Martínez-Echazábal (neste volume), entre outros.

9 Devo ressaltar que mais recentemente delineia-se uma tendência de diversificação nas pesquisas em antropologia física pré-histórica no Brasil, tanto enfocando questões ligadas ao processo saúde/doença (Machado, 1984; Mendonça de Souza, 1995) como processos evolutivos (Neves, 1984; Santos, 1996). Considero, contudo, que a perspectiva teórico-metodológica dos antropólogos do Museu Nacional é bastante representativa da vertente que dominou o campo entre as décadas de 50 e 80

10 Ainda que fora dos departamentos de antropologia, a ativa participação dos geneticistas de população brasileiros em sociedades cientificas como a "American Association of Physical Anthropologists", "Human Biology Council" e a "Sociedade I atino-Americana de Antropologia Biológica", só para citar três casos, bem como a frequiente veiculação de seus trabalhos em periódicos da área de antropologia biológica e biologia humana, como o American Journal of Physical Anthropology, American Journal of Human Biology, Annals of Human Biology e Human Biology, entre outros, atestam seu ativo envolvimento com a comunidade de antropólogos físicos. 
A antropologia física praticada no Museu Nacional a partir dos anos 50 (e até recentemente, na década de 80) foi liderada pelas pesquisas conduzidas por Marília de Mello e Alvim e colaboradores, cujo foco principal foram as coleções esqueletais da própria instituição. O modelo de análise é marcadamente tipológico: empregando métodos que remontam a tradições francesa e alemã do século XIX - o monumental Lehrbuch der Anthropologie (1914), do antropólogo físico alemão Rudolf Martin, serve como uma das principais fontes metodológicas,$-{ }^{11}$ os trabalhos são repletos de tabelas nas quais são reportadas dados morfológicos e morfométricos primários e suas combinações através de índices. Medição e descrição não raro constituem as metas finais das análises. Contudo, há uma diferença importante em relação à percepção acerca dos limites das explicações, se comparada à antropologia física do século XIX: as análises destes pesquisadores do Museu Nacional não buscam relacionar características anátomo-morfológicas (capacida-

de craniana, índice cefálico etc.) com variáveis comportamentais, por exemplo. ${ }^{12}$
Ainda que "raça" ou expressões derivadas raramóntos pesquisadores do Museu que se atrelam a noções tipológi, suas análises são claramente racializadas, uma vez rior à infusão a ilustrativo desto drabalho publicado em 1963 é bastante análise de desta tendência (Mello e Alvim, 1963). A proposta é averiguar, através da te) semelhantes ou os índios "Botocudos" são morfologicamente (leia-se, racialmenNacional, isto é, Lagoa Santa e indivíduos de duas outras séries do acervo do Museu é expandir uma sugestão de dois antropuis (1963:5). No trabalho é frisado que o objetivo - Lacerda e Peixoto - que "fortropólogos físicos do Museu Nacional do século XIX no panorama racial indíge "formularam hipóteses sobre a posição dos [...] 'Botocudos' uma continuidade teórico- (Mello e Alvim, 1963:5). Percebe-se, portanto, antes. A natureza tipoló-metodologica com questões levantadas mais de meio século transcrito a seguir que, num racializada da abordagem é mais que evidente no trecho fológicas, resume os achados da invado de termos que se referem a características mor-

Os trinta e três crânios aqui descritos são predominantemente dolicocrânios, hipsicrânios, acrocrânios, metriometópicos ou eurimetópicos, de foramen magnum estreito, ortometópicos, mesoprósopos ou euriprósopos, mesenos ou eurienos, mesoconcos, mesorrinos, leptoestafilinos, ortoestafilinos ou hipsiestafilinos e mesognatas. (Mello e Alvim,

Se nos centros mais tradicionais passou-se à margem das proposições neodarwinianas, o mesmo não se pode dizer acerca de outro ramo da antropologia física no País: as pesquisas em genética de populações. Como mostra Glick (1994), a genética experimentou grande expansão no Brasil a partir da década de 40 , tendo sido particularmente in-

11 Como bem coloca Proctor (1988:141-142) em seu estudo sobre a trajetória da antropologia física na Alecom a tradição francesa de Broca e Topinard com extudo das raças e sua obra alinhava-se proximamente

Para uma discussão acerca da antropologia física e sua busca de corręões.

cas com parâmetros comportamentais, XIX, vide Stocking (1968), Stepan (1982) e Gould na tradição francesa e norte-americana do século Schwarcz (1993), Monteiro (neste volume), entre outros. 
fluenciada pelo neodarwinismo que na época se consolidava como um poderoso paradigma teórico. Para tal contribuiu o fato de pesquisadores, como T. Dobzhansky, com significativa contribuição teórica para a síntese neodarwiniana, bem como para as "Declarações sobre Raça", terem realizado pesquisas e lecionado no Brasil neste período de consolidação da genética (Glick, 1994).

Em um importante trabalho para a compreensão da trajetória das pesquisas em genética de populações no Brasil - "Populações Brasileiras: Aspectos Demográficos, Genéticos e Antropológicos" -, Francisco M. Salzano e Newton (1967) assim definiram "raça":

...conjunto de indivíduos ocupando uma determinada área geográfica, cruzando-se entre si e geneticamente distintos de outros conjuntos da mesma espécie [...] raça é: 1) uma população, 2) predominantemente endogâmica, e 3) caracterizada por uma comunidade de genes diversa da que caracteriza outras populações. (Salzano \& Freire-Maia, 1967:168)

A escrita destes geneticistas, pontuada por termos como "espécie", "população", "endogamia", "genes" etc., revela estreita proximidade com o neodarwinismo. De fato, a definição de "raça" acima baseia-se em fatores como distribuição espacial, isolamento reprodutivo e freqüência de genes em nível populacional. Traços morfológicos externos, que no passado constituíram o cerne das classificações raciais, não são sequer mencionados diretamente. Além disso, para os geneticistas "raça" é um conceito probabilístico que se aplica a um conjunto de indivíduos, e não a indivíduos tomados isoladamente. A análise da biologia humana da população brasileira por Salzano \& Freire-Maia (1967) é fiel a este delineamento de "raça": além de ocupar um plano bastante secundário se comparada à "população", nos poucos momentos em que "raça" surge recebe um tratamento neodarwinismo, sem aproximações tipológicas.

É curioso observar, contudo, que mesmo que teoricamente priorizando uma leitura neodarwiniana de "raça", procedimentos metodológicos empregados em certas pesquisas em genética de populações revelam o que se poderia denominar de resquícios de uma perspectiva tipológica. Este é o caso das investigações sobre "mistura racial" ou "análise dos componentes raciais". Tomando uma amostra de pessoas (de uma vila, de uma cidade ou até mesmo de um estado ou de toda uma região), tais pesquisas visam averiguar a contribuição dos diferentes "componentes raciais" na constituição genética do grupo em apreço. No tocante à metodologia, usualmente os sujeitos participantes da investigação são "racialmente" classificados pelos próprios pesquisadores com base em atributos físicos externos. Estas investigações partem da premissa de que certas variantes de marcadores genéticos (grupos sangüíneos, por exemplo) são exclusivos ou ocorrem em maior freqüência num ou noutro "componente", podendo ser utilizados como "marcadores raciais". A partir da análise das freqüências em cada um dos "componentes", estima-se através de tratamento estatístico o "grau de mistura" racial. ${ }^{13}$

13 A literatura sobre genética e "mistura racial" no Brasil é vasta (vide Salzano \& Freire-Maia 1968:153156; Salzano 1979:57-77; Freire-Maia 1983). Salzano (1986) provê explicação tecnicamente acessível acerca destes estudos para não-especialistas. É importante frisar que os estudos sobre "mistura racial" não se limitam ao Brasil, sendo comumente realizados em outras partes do mundo. 
O estudo de Krieger et al. (1965) é um importante marco nas investigações sobre "mistura racial" no Brasil. Os procedimentos matemáticos propostos por estes autores, com certas modificações, continuam a ser seguidos até o presente. Nos interessa aqui o tratamento metodológico dispensado à "raça" e à classificação racial, que foi o seguinte:

Durante o exame médico, cada individuo participante do estudo foi racialmente classiftcado com base na pigmentação do abdomen, cor e tipo de cabelo, conformação do nariz e dos lábios [...]. O médico que procedeu o exame é nativo da Bahia e seu julgamento, ainda que necessariamente subjetivo, baseou-se numa experiência pessoal adquirida ao longo de toda a vida. Atribuiram-se códigos as diversas classes [i.e., branco, amarelo-claro, amarelo-escuro, mulato-claro, mulato-médio, mulato-escuro, preto], desde 0 (mais caucasóide) até 8 (mais negróide)... (Krieger et al., 1965:115-116)

A maior parte do trabalho consiste da derivação de um complexo algoritmo visando estimar, a partir da freqüência de genes, os graus de "mistura racial". Krieger e colaboradores concluem que a "composição racial" da amostra inclui 58\% de genes de origem caucasóide, $31 \%$ negróide e $11 \%$ indígena.

Investigações sobre "mistura racial"' continuam bastante comuns no Brasil em períodos recentes (vide Franco et al., 1982; Salzano, 1986; Santos \& Guerreiro 1995; entre outros). Os procedimentos quantitativos para estimar os graus de "mistura racial" freqüentemente baseiam-se em Krieger et al. (1965), inclusive com os indivíduos participantes do estudo morfologicamente classificados pelos pesquisadores em grupos raciais a partir de características morfológicas externas. Estas investigações geram conclusões como a seguinte:

\begin{abstract}
... em Porto Alegre, pessoas classificadas como brancas por suas características aparentes têm, em média, 8\% de genes de origem africana [...] Quanto aos identificados como negros ou mulatos, estudos feitos no Rio de Janeiro, em São Paulo, Curitiba e Porto Alegre sugerem que a metade de sua constituição genética seria de origem caucasóide. (Salzano, 1986:52)
\end{abstract}

Os exemplos acima apontam claramente para a persistência do conceito de "raça" em pesquisas genéticas. Mais do que isto, revelam que, ainda que tenha sido um conceito intensamente problematizado e redefinido à luz do neodarwinismo, mesmo na genética de populações contemporânea a categoria "raça' faz-se presente com resquícios tipológicos, 14 ainda que convivendo lado a lado com "polimorfismo", "genes", "fluxo gênico", "deriva genética”, ou seja, com termos essencialmente pós-síntese. Ou seja, ainda

14 Não quero dizer com isso que os geneticistas estejam alheios às dificuldades de efetuar classificações raciais, como bem revelam Salzano (1979:62) ao afirmar que "o número de raças a serem distinguidas depende, basicamente, da conveniência do pesquisador", Freire-Maia (1979:27) ao enfatizar que "o conceito de raça deve ser prático mas, infelizmente, não é suficientemente objetivo para que os limites das raças sejam precisos e bem delimitados" ou Dobzhansky (1965:256) ao frisar que uma "deficiência fatal das tipologias raciais é que os tipos morfológicos são delineados a partir de um tipo de intuição, o que significa que são selecionados arbritariamente, mesmo quando escolhidos por investigadores experientes". É interessante notar também que os geneticistas freqüentemente chamam atenção para a "subjetividade" embutida nos procedimentos de classificação racial (cf. Krieger et al., 1965:115; Santos et al., 1987:746; entre outros). Santos et al. (1987:746), por exemplo, indicam que "a classificação racial foi realizada subjetivamente, considerando-se cor de pele, tipo de cabelo, formato do nariz e outras características". Subjetivas ou não, o fato é que classificações são levadas a cabo. 
que os estudos sobre "mistura racial" tenham um delineamento teórico essencialmente neodarwiniano, o tratamento metodológico para "raça" e classificação racial aproximase muito de uma perspectiva tipológica diretamente traçável a uma antropologia física pré-síntese.

\section{CONCLUSÃO}

No início deste trabalho referi-me a "hibridez" e "singularidade", expressões que foram recentemente empregadas por Araújo (1994) em seu estudo sobre a obra de Gilberto Freyre nos anos 30, onde sugere que, ao contrário do que comumente se imagina, a noção de que "cultura" veio a substituir "raça" é uma simplificação de um tratamento bem mais complexo dispensado a esta díade em Casa-Grande \& Senzala. Segundo Araújo (1994:31),

o destaque recebido pela noção de raça não se concentra em uma passagem localizada nem se refere apenas a um ou outro dos grupos sociais [...] Ao contrário, ela dá a impressão de se distribuir, ainda que de forma irregular e sempre dividindo o seu prestigio com o conceito de cultura.

Em outras palavras, Araújo sugere que tenha ocorrido, em vez de ruptura, uma "híbrida e singular articulação" (1994:30) conceitual.

A argumentação desenvolvida ao longo deste trabalho sugere que a interpretação de Araújo encontra ressonância no que ocorreu $\mathrm{cm}$ antropologia física e vice-versa. Houve claramente uma tendência de deslocamento de "raça", em sua versão tipológica, para "população", um conceito chancelado pela síntese neodarwiniana. Este realinhamento conceitual tampouco se concretizou abruptamente; pelo contrário, "raça" não foi descartada, mas adaptada ao evolucionismo que penetrou na disciplina a partir dos anos 40 . Um dos resultados deste processo foi que, pelo menos em teoria, "raça" foi retirada do plano primário, tornando-se atrelada à "população", que passou a ser a unidade privilegiada de análise. Como afirmou Stanley Garn, num comentário que encontra respaldo no discurso teórico (ainda que nem sempre na prática) da maioria dos antropólogos físicos contemporâneos, "raça' é tão somente "uma população em isolamento reprodutivo, nem mais, nem menos", (1971:5). Mas o fato é que o processo de transição desde "raça' a "população" ainda está por findar. Mesmo nos dias atuais, apesar do contínuo mergulho (técnico) desde a morfologia às moléculas e a progressiva incorporação de conceitos oriundos do evolucionismo neodarwiniano, ainda se percebe um tratamento tipológico para "raça" em antropologia física.

\section{AGRADECIMENTOS}

A Carlos E. A. Coimbra Jr., Eduardo Viveiros de Castro, Francisco M. Salzano, Lucia Morales, Marcos Chor Maio, Nancy Flowers e Sheila Mendonça de Souza pela leitura crítica do texto e pelas valiosas sugestões de bibliografia. 


\section{REFERÊNCIAS BIBLIOGRÁFICAS}

ARAÚJO, R. B., 1994. Guerra e Paz: Casa-Grande \& Senzala e a Obra de Gilberto Freyre
nos Anos 30. Rio de Janeiro: Editora 34 .

ARMELAGOS, G., 1992. The concept of race, racism and anthropology. Trabalho apresentado no simpósio "Political-economic Perspectives in Biological Anthropology: Building a Biocultural Synthesis', Wenner-Gren Foundation International Symposium. Cabo San Lu-
cas, México. BARKAN, E., 1992. The Retreat of Scientific Racism. Cambridge: Cambridge University
Press.

BOAS, F., 1940. Race, Language and Culture. New York: Macmillan. BOWLER, P. J., 1989. Evolution: The History of an Idea. Berkeley: University of California
Press.

CASTRO-FARIA, L., 1952. Pesquisas de antropologia física no Brasil. Boletim do Museu Nacional (antropologia), 13:1-106.

CORRÊA, M., 1982. As Ilusões da Liberdade: A Escola Nina Rodrigues e a Antropologia no Brasil. Tese de Doutorado, São Paulo: Universidade de São Paulo.

DOBZHANSKY, T., 1965. Mankind Evolving. New Haven: Yale University Press.

DUNN, L. C., 1951. U.N.E.S.C.O.'s new statement on race. Man, 51:154-155.

FLEURE, H. J., 1951. Letter. Man, 51:16.

FRANCO, M. H. L. P.; WEIMER, T. A. \& SALZANO, F. M., 1982. Blood polymorphisms and racial admixture in two Brazilian populations. American Journal of Physical Anthropolo-

FREIRE-MAIA, N., 1983. Brasil: Laboratório Racial. Petrópolis:Vozes.

GARN, S. M., 1971. Human Races. Springfield: Charles C. Thomas.

GLICK, T., 1994. The Rockfeller Foundation and the emergence of genetics in Brazil, $1943-$ 1960. In: Missionaries of Science: the Rockfeller Foundation and Latin America (M. Cueto, ed.), pp. 149-164. Bloomington: Indiana University Press.

GOODMAN, A., 1995. The problematics of "race" in contemporary biological anthropology. In: Biological Anthropology: The State of the Science (N. T. Boaz \& L. D. Wolfe, eds.), pp. 215-249. Bend: International Institute for Human Evolutionary Research.

GOULD, S. J., 1991. A Falsa Medida do Homem. São Paulo: Martins Fontes.

GOULD, S. J., 1995. Ghosts of bell curves past. Natural History, 104(2):12-19.

GREENE, J. C., 1990. The interaction of science and world view in Sir Julian Huxley's evolutionary biology. Journal of the History of Biology, 23:39-55. HARAWAY, D., 1989. Primate Visions: Gender, Race, and Nature in the World of Modern
Science. New York: Routledge.

HILL, W. C. O., 1951. Letter. Man, 51:16-17. 
HOOTON, E., 1936. Plain statements about race. Journal of the American Association of University Women, June, 20:1-4.

KRIEGER, H.; MORTON, N. E.; AZEVEDO, E.; FREIRE-MAIA, N. \& YASUDA, N., 1965. Racial admixture in northeastern Brazil. Annals of Human Genetics, 29:113-125.

LITTLE, K. L., 1951. Letter. Man, 51:17.

MACHADO, L. C., 1984. Análise de Remanescentes Humanos do Sitio Corondó. Aspectos Biológicos e Culturais. Rio de Janeiro: Instituto de Arqueologia Brasileira.

MAYR, E., 1982. The Growth of Biological Thought: Diversity, Evolution, and Inheritance. Cambridge: Harvard University Press.

MELLO E ALVIM, M. C., 1963. Diversidade morfológica entre os índios "Botocudos", do leste brasileiro (século XX e o "Homem de Lagoa Santa"). Boletim do Museu Nacional (antropologia), 23:1-85.

MENDONÇA DE SOUZA, S. M., 1995. Estresse, Doença e Adaptabilidade: Estudo Comparativo de Dois Grupos Pré-históricos em Perspectiva Biocultural. Tese de Doutorado, Rio de Janeiro: Escola Nacional de Saúde Pública, Fundação Oswaldo Cruz.

NEVES, W. A., 1984. Paleogenética dos Grupos Pré-Históricos do Litoral Sul do Brasil (Paraná e Santa Catarina). Tese de Doutorado, São Paulo: Instituto de Biociências, Universidade de São Paulo.

PROCTOR, R., 1988. From anthropologie to rassenkunde in the German anthropological tradition. In: Bones, Biology and Behavior: Essays on Biological Anthropology (G. W. Stocking, ed.), pp. 138-179. Madison: University of Wisconsin Press.

PROVINE, W. B., 1973. Geneticists and the biology of race crossing. Science, 182:790-796.

SALZANO, F. M., 1979. Você e sua Herança: Questões Básicas de Genética e Antropologia Física. Rio de Janeiro: Civilização Brasileira.

SALZANO, F. M., 1986. Em busca das raízes. Ciência Hoje, 5(25):48-53.

SAlZANO, F. M. \& FREIRE-MAIA, N., 1967. Populações Brasileiras: Aspectos Demográficos, Genéticos e Antropológicos. São Paulo: Companhia Editora Nacional/Editora da USP.

SANTOS, A. K. C. R., 1996. Diversidade de Linhagens de INA Mitocondrial de Ameríndios da Amazônia: Populações Contemporâneas e Ancestrais. Tese de Doutorado, Ribeirão Preto: Faculdade de Medicina da Universidade de São Paulo.

SANTOS, S. E. B.; GUERREIRO, J. F.; SALZANO, F. M.; WEIMER, T. A.; HUTZ, M. H. \& FRANCO, M. H. L. P., 1987. Mobility, blood genetic traits and race mixture in the Amazonian population of Oriximiná. Revista Brasileira de Genética, 10:745-759.

SANTOS, S. E. B \& GUERREIRO, J. F., 1995. The indigenous contribution to the formation of the population of the Brazilian Amazon region. Revista Brasileira de Genética, 18:311315 .

SCHWARCZ, L. M., 1993. O Espetáculo das Raças: Cientistas, Instituições e Questão Racial no Brasil 1870-1930. São Paulo: Companhia das Letras.

SEYFERTH, G., 1985. A antropologia e a teoria do branqueamento da raça no Brasil: a tese de João Batista de Lacerda. Revista do Museu Paulista 30:81-98. 
STEPAN, N., 1982. The Idea of Race in Science: Great Britain 1800-1960. London: MacMillan Press.

STOCKING, G. W., 1968. Race, Culture and Evolution. New York: Free Press.

TRINKAUS, E. \& SHIPMAN, P., 1992. The Neandertals: Of Skeletons, Scientists and Scandals. New York: Vintage Books.

UNESCO, 1952. The Race Concept: Results of an Inquiry. Paris: Unesco.

VALLOIS, H. V., 1951. U.N.E.S.C.O. on race. Man, 51:15-16. 


\section{PARTE III}

O BRASIL COMO "LABORATÓRIO RACIAL": OS ESTUDOS SOBRE RELAÇÕES RACIAIS ENTRE OS ANOS $40 \mathrm{E} 60$ 


\title{
COR, CLASSES E STÁTUS NOS ESTUDOS DE PIERSON, AZEVEDO E HARRIS NA BAHIA: 1940-1960
}

\author{
Antonio Sérgio Alfredo Guimarães
}

\section{INTRODUÇÃO}

A associação entre "cor" e posição social foi sempre fundamental no Brasil e seu estudo ocupou boa parte dos cientistas sociais. Ainda recentemente, dois excelentes artigos, um por Marvin Harris et al. (1993) e o outro por Nelson do Valle Silva (1994), acirraram o interesse no tema, discutindo as inconsistências do sistema de classificação racial adotado nos censos.

Minha intenção nesse artigo, entretanto, limita-se a discutir o significado teórico em que cor, classes e status foram relacionados pelas ciências sociais no Brasil nos anos 40 e 50. Concentro-me particularmente nos estudos clássicos de Donald Pierson, de Thales de Azevedo e de Marvin Harris para examinar os fundamentos de duas hipóteses clássicas sobre a relação entre "cor" e posição social no Brasil: aquela que teoriza as discriminações raciais no Brasil como "discriminações de classe" e aquela outra que explica a especificidade de nosso sistema de relações raciais pela permanência de uma hierarquia estamental criada pela escravidão.

\section{O QUE É COR}

"Cor" é, no Brasil, primitivamente, uma construção racialista que se estrutura em torno de uma ideologia bastante peculiar. Segundo tal ideologia, os mestiços de diferentes raças tendem, através de um processo de "reversão", a concentrar-se em torno das características de algumas raças fundamentais.

O conceito de reversão pode ser melhor entendido lendo-se a passagem na qual o autor de Os Sertões explica o embranquecimento dos mestiços de negro:

As leis naturais pelo próprio jogo parecem extinguir, a pouco e pouco, o produto anômalo que as viola, afogando-o nas próprias fontes geradoras. O mulato despreza então, irresistivelmente, o negro e procura com uma tenacidade ansiosíssima cruzamentos que apaguem na sua prole o estigma da fronte escurecida; o mameluco faz-se o bandeirante inexorável, precipitando-se, ferozmente, sobre as cabildas aterradas... [...] Essa tendência é expressiva. Reata, de algum modo, a série contínua da evolução, que a mestiçagem partira. A raça superior torna-se o objetivo remoto para onde tendem os mestiços deprimidos e estes, procurando-a, obedecem ao próprio instinto da conservação e da defesa. É que são invioláveis as leis de desenvolvimento das espécies. (Cunha, 1973 [1906]:97) 
Foi baseada nessa teoria de que os mestiços "revertem" ou "regridem" para uma das raças cruzadas - ideologia que informava tanto o senso comum quanto o saber erudito no final do século passado - que o censo brasileiro de 1872 introduziu quatro "grupos de cor': o branco, o caboclo, o negro e o pardo. Tais grupos são definidos por uma mesma fórmula: grupo de cor = membros da raça pura + fenótipos da raça em reversão.

No grupo branco, por exemplo, estavam, na definição de Oliveira Vianna, "os brancos puros e os fenótipos do branco (mestiços afro-arianos e indo-arianos em reversão para o tipo branco)" (Vianna, 1959 [1932]:45).

Do mesmo modo, Oliveira Vianna define caboclos e negros. Apenas o pardo foge à lei da reversão aos tipos originais. Essa é, para Oliveira Vianna, uma categoria residual:

O grupo dos pardos ou mulatos era constituido por aqueles mestiços afro-arianos, que, pela pigmentação particular da pele, não podendo incorporar-se a nenhuma das raças originárias, formavam um grupo à parte, perfeitamente diferenciado dos outros grupos. (Vianna, 1959 [1932]:45)

Para outros, entretanto, os pardos podem também ser o produto da estabilização, através do intercruzamento continuado, de um novo tipo racial. Por isso a pergunta de Carvalho (1988 [1934]:34): "Qual o typo definido no fim de uns tantos annos, quando por successivas reproducções tenha se esbatido de vez a influência negra?"

Mas com o declínio do prestígio das teorias racialistas no Brasil, a partir dos anos 40, desaparece - pelo menos no nível do discurso e da consciência - os apelos a teorias raciais na definição da cor, tal como a teoria que explicava pela reversão a fixação de caracteres somáticos, fenotípicos e de caráter. Os grupos de cor passam a ser pensados em termos de senso comum como enquadrando apenas características fenotípicas, desaparecendo a sua explicitação racialista e sustentando-se apenas numa ideologia da espontaneidade e obviedade de nossas percepções cromáticas e físicas.

Tal ideologia alicerça-se empiricamente na constatação de que há uma plêiade de denominações para definir-se a "cor" de alguém. Nesse sentido, "cor" é tomada como categoria empírica, manifestação objetiva de características fenotípicas, ainda que sua denominação seja inteiramente subjetiva e ambígua, por falta de uma regra precisa de descendência racial.

$\mathrm{Na}$ sua crítica radical às teorias racialistas, a moderna Antropologia Social procurou retirar da "cor" e dos "grupos de cor" qualquer conotação racial. Mas, procurou também, guardando a designação "emic", nativa, afastar-se do discurso do senso comum que associa cor à pigmentação.

As características fenotípicas que compõem a "cor" das pessoas foram sistematicamente estudadas pela Sociologia e Antropologia Social a partir do estudo pioneiro de Donald Pierson sobre as relações raciais em Salvador nos anos 30 (Pierson, 1971 [1942]).

"Cor", tal como passou a ser formulada pelas ciências sociais no Brasil, em substituição à "raça", ou aos grupos de cor censitários, é uma categoria "nativa" (emic) e significa mais que pigmentação da pele. Como Donald Pierson corretamente observou na segunda edição ao seu famoso livro Brancos e Pretos na Bahia:

Tal como se emprega no Brasil, [...] 'cor' significa mais que simples cor, isto é, mais do que pigmentação, [significa] inclusive, em primeiro lugar, [a presença] de um certo número de outras características fisicas: tipo de cabelo (talvez o mais importante), assim como os traços fisionômicos. (Pierson, 1971:38) 
A afirmativa original de Pierson foi, mais tarde, comprovada pelas observações sistemáticas de Harris \& Kontak (1963), que conseguiram mensurar a importância das características físicas na definição da cor de um indivíduo. São elas, por ordem de importância: a cor da pele, o tipo de cabelo, o formato do nariz e o formato dos lábios.

Tal significado da "cor" foi ampliado ainda mais à medida que a Antropologia Social afastava-se dos pressupostos racialistas e enveredava pelos estudos de relações raciais. De fato, a principal característica do "sistema de relações raciais" brasileiro, tal como estabelecido pelos estudos dos anos 40,50 e 60, é menos a novidade de seu sistema de classificação - a ausência de regras de descendência, como o caracterizou Harris (1964) -, e mais a sua estreita associação com a hierarquia social, i.e., com a estratificação socioeconômica e com a estratificação do poder e do prestígio social.

Pierson, que entre 1935 e 1937, realizou o primeiro estudo sistemático de "situação racial" no Brasil, ao notar essa associação entre "cor" e posição social, "traduziu-a" nos termos da sociologia da época: os grupos de cor pertenceriam a uma ordem de classe e não a uma ordem de casta, seriam, portanto, grupos abertos e não grupos fechados; ou melhor, não seriam rigorosamente grupos, pois aos seus membros faltaria consciência de grupo.

A caracterização do Brasil como uma sociedade multirracial de classes (Pierson, 1971) demarcou o terreno dos estudos de relações raciais no Brasil por mais de vinte anos. Segundo este paradigma, o principal traço da sociedade brasileira seria o de que nela não apenas a "raça" é definida por traços fenotípicos (a "cor", em sentido lato) como também participariam da sua definição critérios sociais, como riqueza e principalmente a educação (Harris, 1964). Essa é a construção teórica que sustenta a intuição de uma democracia racial, na qual mais que a "cor" das pessoas (ou seja, suas características ascritivas) importaria o seu desempenho (riqueza e educação).

\section{CLASSES E STATUS}

O conceito de classes, tal como utilizado pelas ciências sociais americanas nos anos 30 , tinha dois sentidos correlatos. Por um lado, o termo designava qualquer divisão vertical ou agrupamento hierárquico de uma dada sociedade. Foi com esse sentido genérico, por exemplo, que A. L. Kroeber se referiu a classes na passagem
abaixo:

A casta e o clã podem ser descritos de um modo geral como divisões vertical e horizontal, respectivamente, de uma população. Por conseguinte, as castas são uma forma especial de classes sociais, que, pelo menos em tendência, estão presentes em toda sociedade. Contudo, as castas diferem das classes sociais nisto que elas emergiram na consciência social no ponto em que o costume e o direito procuraram separar-se rígida e permanentemente um do outro. As classes sociais são o solo de que os sistemas de casta brotaram independentemente em várias épocas e lugares. (Kroeber, 1970:413)

Por outro lado, classes são um tipo específico de estrato vertical, caracterizado pela predominância de relações sociais abertas, tais como conceituadas por Weber. São, portanto, em sentido estrito, camadas abertas que se contrapõem às castas, que são
camadas fechadas. 
Esse segundo sentido do termo classes pode ser ilustrado pela seguinte definição de Lloyd Warner:

'Casta', no sentido em que usamos aqui este termo, descreve uma disposição teórica das pessoas de determinado grupo em uma ordem em que privilégios, deveres, obrigações, oportunidades, etc., se distribuem desigualmente entre os grupos considerados superior e inferior. Existem sanções sociais que tendem a manter esta distribuição desigual. Muito dessa definição também serve para descrever a 'classe'. Um sistema de castas, contudo, deve ser além disso definido como aquele em que o casamento entre os dois grupos não é sancionado e em que não há a oportunidade para os membros do grupo inferior ascenderem ao superior, ou para os membros do grupo superior descerem ao inferior. Num sistema de classes, por outro lado, há certa proporção de casamentos entre as classes inferior e superior; e há, na própria natureza da organização de classes, mecanismos estabelecidos pelos quais as pessoas se deslocam para o alto ou para baixo nas extensões verticais da sociedade. (Warner, 1970:419)

Para Warner, portanto, tanto classes quanto castas são camadas de uma estrutura vertical. A diferença da casta como relação à classe está na (i) endogamia e (ii) na ausência de mobilidade social.

Essas divisões verticais da estrutura social estão ambas associadas a diferentes status, isto é, a uma distribuição desigual da honra e do prestígio social, tal como se depreende dessa outra passagem, escrita por Allison Davis \& John Dollard:

As formas de participação da clique e das classes sociais são do tipo íntimo, o que implica que os seus membros partilham um status igual no sentido de que se visitam uns aos outros, desenvolvem rituais interfamiliares tais como refeições ou chás, e podem casar entre si. (Davis \& Dollard apud Myrdal, 1944:1377)

Podemos dizer que, para a sociologia do começo do século, do ponto de vista da distribuição do status social, classes se diferenciavam das castas, por ostentarem as primeiras um status adquirido, enquanto as castas apenas conservavam status atribuido. Tal diferenciação pauta-se, todavia, numa valorização positiva, em termos ideológicos e culturais, das classes, que precisa ser realçada.

As divisões em classes, porque são concebidas como se devendo apenas a diferenças adquiridas pelos indivíduos como resultado de sua competição num mercado livre, são também valorizadas como "boas" diferenças, ao contrário das diferenças existentes nas castas, às quais, por se deverem a características herdadas e inatas, independente do desempenho individual, são consideradas "más" diferenças.

Aliás, a única conotação negativa do termo "classe" ocorre apenas quando esse está associado a restrições à livre competição dos indivíduos, restrições essas provenientes de privilégios. Esse sentido britânico do termo "classe" foi melhor expresso por Myrdal quando disse:

Classes e diferenças de classe na América são nessa pesquisa concebidas como resultado da restrição à livre competição e, conseqüentemente, da falta de uma completa integração social. As classes altas desfrutam os seus privilégios porque as classes baixas são constrangidas na 'sua busca de felicidade' por vários tipos de monopólios sociais relativos e absolutos. (Myrdal, 1944:674) 
No Brasil, entretanto, as classes tendem a ser sempre valorizadas negativamente pois, à maneira marxista, nos inclinamos a associar as classes a mecanismos de exploração do trabalho, a formas de parasitismo social, à manutenção de privilégios e à exclusão social. O leitor brasileiro, portanto, que não participa do universo de valor que encara positivamente as classes, deve ficar atento à maneira positiva com que os cientistas sociais das décadas de 40, 50 e 60 relacionaram classes e status à cor.

Em seguida passarei rapidamente em revista o modo como Donald Pierson, Marvin Harris e Thales de Azevedo enunciaram e desenvolveram a tese segundo a qual o Brasil é uma "sociedade multirracial de classes".

\section{DONALD PIERSON}

A tese de Pierson só faz sentido se entendida no contexto teórico da sociologia americana da época.

Particularmente, é fundamental recordar a teoria de interação social, tal como formulada por Robert Park e outros professores da Universidade de Chicago. Segundo essa teoria, isolamento e contato são categorias que organizam a explicação seja da evolução das culturas em torno do eixo "cultura de folk/civilização", seja do desenvolvimento e amadurecimento das personalidades individuais.

O contato entre diferentes pessoas ou povos, tido como o responsável pelo progressivo refinamento intelectual e cultural, dar-se-ia basicamente através de quatro processos geralmente vistos como etapas do processo civilizatório mais abrangente; e, em particular, do modo como a sociedade norte-americana constituía-se pela absorção e integração de amplos contingentes migratórios. Esses quatro processos são: competição, conflito, acomodação e assimilação.

Competição, para Pierson, é “a forma mais elementar e universal de interação; é a luta por objetos concretos (a própria vida, bens); é inconsciente, impessoal, contínua; produz: 1) ordem econômica, 2) divisão do trabalho, 3) distribuição em espaço..." (Pierson, 1975:322). Quando consciente, a competição torna-se conflito, passa então a ser intermitente, a produzir status e ordem política; diminui apenas através da acomodação e desaparece através de assimilação.

Classes e castas seriam, segundo a perspectiva adotada por Pierson (1975:321), fenômenos de acomodação - "ajustamento apenas formal e externo, cuja função é a de diminuir o conflito"; ou seja, seriam grupos sociais que se formavam num processo de competição e que se cristalizavam de modo a evitar a continuidade de um conflito que seria social e culturalmente destrutivo. Tal conflito só poderia ser finalmente resolvido pela assimilação final desses grupos ou pessoas aos valores da sociedade global.

No dizer de Pierson, classe é:

uma camada social aberta, cujos membros compartilham de certas qualidades sociais e pessoais decorrentes de uma similaridade de ascendência, ocupação, educação, nivel econômico, idéias, atitudes, etc., e que possuem "status" aproximadamente igual dentro da mesma ordem social; é um dos grupos de acomodação. (Pierson, 1975:322)

Vê-se, pois, que as classes sociais, para Pierson, (a) são conceitualmente camadas da estrutura social indistintas de grupos de status; (b) são camadas abertas e portanto 
conceitualmente opostas às castas, que são fechadas; (c) são formadas num processo de conflito que só pode ser supresso pela assimilação de valores, atitudes e interesses. 1

A Bahia de 1935, segundo Pierson, é uma cidade de mestiços afro-europeus, ao contrário do Recôncavo que seria negróide. Cidade culturalmente isolada, área culturalmente passiva como ele a define, tomando o conceito de empréstimo a Robert Park, a Bahia é caracterizada como uma sociedade patriarcal, familial, onde predominavam "relações primárias" e onde a competição era baixa e os conflitos econômicos inexistentes.

A justificativa de Pierson para escolher a Bahia como local de seu estudo das relações raciais no Brasil, é "porque é ali que a acomodação racial vem se processando há séculos e com alto grau de persistência..." (Pierson, 1971:91).

$\mathrm{Na}$ caso de Salvador, Pierson divide a cidade em três zonas residenciais às quais correspondem, grosso modo, as classes econômicas e educacionais - ricos, pobres e remediados - e as cores - brancos, pretos e mestiços.

Essa segregação seria, entretanto, involuntária e inconsciente, no sentido de não objetivarem a manutenção de distinções de grupos fechados (castas). Serão as exceções a esse padrão residencial que, na análise de Pierson, demonstrarão o caráter apenas aparentemente racial dessa forma de segregação. E isto porque as exceções seguiriam todas um padrão único de distribuição por classes sociais.

Para fortalecer a idéia de transitoriedade dessa segregação espacial e, ao mesmo tempo, justificar uma certa imobilidade aparente, que transparece em algumas passagens do texto, Pierson introduz no argumento a idéia de que a Bahia é "uma sociedade de competição comparativamente livre e de desenvolvimento gradual" (Pierson, 1971:106). Ora, quando antes Pierson caracterizara a Bahia como uma sociedade estável e isolada seria de se esperar que ele observasse alguma sedimentação de diferenças estamentais. Ao dizer depois que tratava-se de uma sociedade de competição livre, Pierson parece querer sugerir que tal sedimentação era transitória no sentido de se desfazer gradual e lentamente ao incorporar cada vez mais mulatos e mestiços em suas classes dominantes. Como não havia nenhuma barreira legal ou uso da violência física contra a ascensão social, Pierson é levado a preconizar como causa da segregação transitória uma desvantagem inicial (a escravidão, a falta de recursos e de educação) que só lentamente poderia ser revertida.

As exceções à simetria entre classe e cor antes de confirmarem uma regra possível - isto é, a existência de uma organização social muito rígida, baseada em status estáveis, guardados por distâncias sociais (polidez e etiquetas), culturais (analfabetismo e costumes africanos) e econômicos (desemprego crônico e pobreza) - são tomadas como falsificadoras daquela simetria, como prova de que a cor não funcionava como princípio organizativo, mas sim as classes.

É como se a polaridade teórica entre classes e castas, por formarem uma dicotomia simples e "realista" (camadas abertas ou fechadas) ao invés de extremos de um contínuo

Mas classes, como o termo é muitas vezes empregado por Pierson, se refere também a qualquer compartimentação vertical em grupos da estrutura social. É, aliás, com esse sentido que o termo aparece pela primeira vez em Brancos e Pretos na Bahia: "Essa fisiografia da região não deixava de ter importância na vida cultural da Bahia; porque, em geral, a distribuição da população por classe, e até certo ponto por
grupos de côr, seguia de perto a configuração da terra" (Pierson, 1971:97). 
ideal-típico, impedissem Pierson de observar a rigidez histórica das posições sociais. Ao contrário, essa persistência quando notada é atribuída ao isolamento e à baixa competitividade e à inexistência de conflitos na sociedade baiana. As classes, fenômenos de acomodação, portanto, seriam na Bahia estranhamente reforçadas pela ausência de conflitos.

Interessante notar, a esse respeito, que a dicotomia "classe/castas" é pensada em termos da ausência ou, alternativamente, da presença de uma "linha de cor", do mesmo modo que Myrdal (1944) pensa a "linha de casta" em seu American Dilemma - a presença de mestiços tanto entre os ricos, quanto entre os pobres, isto é, a ausência de uma classificação bipolar brancos e pretos, é tomada como ausência de uma linha de raça ou de casta, e essa ausência é automaticamente expressa pelo conceito de classe, um grupo social aberto. Esse procedimento é grandemente facilitado pelo fato de Pierson não usar a autodefinição de cor, empregando, portanto, critérios absolutos, fisionômicos, para definir as cores ou raças.

Pierson vai precisamente argumentar no capítulo $\mathrm{V}$ do seu livro que foi a miscigenação que diluiu a linha de cor e desorganizou as castas que existiram no período colonial. O argumento é complexo. Pierson reconhece, primeiramente, seguindo Park, que a miscigenação é uma estratégia geral de conquista e de transplantação de povos. Mas, logo em seguida, começa a descrever os fatores que tornam particular a extensão com que se deu a miscigenação brasileira, tomando de empréstimo a Gilberto Freyre alguns argumentos a respeito do caráter e das características dos portugueses e da situação demográfica de Portugal. Seriam eles: primeiro, o fato de os portugueses já estarem familiarizados com povos mais escuros e serem eles próprios, em grande parte, mestiços; segundo, a maior tolerância à mancebia e a aceitação pela Igreja de casamentos inter-raciais; e terceiro, o maior status associado à cor branca, que levava as mulheres e os homens a procurarem parceiros mais claros.

Ora, nesse último argumento, tomando tais atitudes e atos como algo normais, Pierson deixa escapar precisamente a chave da hierarquia racial e do preconceito racial brasileiros.

Para Pierson, em resumo, na sociedade baiana e brasileira em geral não existiam castas raciais ou mesmo grupos raciais sticto sensu posto que brancos, pretos e mestiços eram encontráveis, de fato e em tese, ainda que em proporções diferentes, em todas as classes e grupos sociais. Como não existia uma "linha de cor" separando o contato e a interação entre os membros de uma classe e os grupos sociais entre si, o Brasil seria tipicamente uma sociedade multirracial de classes. Essa concepção de sociedade de classes se contrapõe à concepção de uma sociedade dividida ao mesmo tempo em classes e em castas raciais, tal como a sociedade sulista dos Estados Unidos caracterizada por Lloyd Warner (1970).

A simplicidade dessa conceituação e sua obviedade apenas reproduzia em linguagem científica o que já era o senso comum de brasileiros e estrangeiros em 1940 sobre as relações raciais no Brasil; a saber, a de que as discriminações e as desigualdades no Brasil não eram propriamente raciais, mas simplesmente sociais ou de classe. Tão óbvia era essa conclusão que Arthur Ramos, prefaciando a $1^{\text {a }}$ edição brasileira de Brancos e Pretos na Bahia, dirá:

Mas cumpre logo registrar que, utilizando-se dos seus métodos objetivos de estudo das relações humanas, Pierson chega às mesmas conclusões que estavam admitidas, vamos dizer, tradicionalmente. (Pierson, 1971:69) 
O peso dessa tradição é enorme e une autores das mais diversas corrente de pensamento. Caio Prado Júnior, por exemplo, mesmo empregando um conceito de classe mais preciso - referido, ao modo marxista, a uma estrutura econômica e a um modo de produção bem definidos - não escapa a esse senso comum, escrevendo no mesmo ano de 1942 em que aparece a $1^{\mathfrak{a}}$ edição americana do livro de Pierson:

O fato incontestável ... é que a diferença de raça, sobretudo quando se manifesta em caracteres somáticos bem salientes, como a cor, se não vem provocar - o que é passivel de dúvidas bem fundamentadas, e a meu ver incontestáveis -, pelo menos agravar uma discriminação já realizada no terreno social. E isto porque empresta uma marca iniludivel a esta diferença social. (Prado Júnior, 1965:272)

Caio Prado, contudo, tem sobre Pierson a enorme vantagem analítica de afirmar a existência do preconceito racial $^{2}$ e, o que é mais importante, realçar as suas conseqüências. Ao fazê-lo, Caio Prado reconhece implicitamente a sobreposição de duas ordens sociais, uma econômica e outra racial, abrindo portanto a possibilidade teórica de se tratar empiricamente a interrelação entre essas duas ordens, como o farão mais tarde Thales de Azevedo, Florestan Fernandes e outros.

Ao contrário, Donald Pierson, para dar substância mais polêmica a uma tese aceita sem problemas pelo senso comum da época, procurará negar a existência do preconceito ou da discriminação racial e, no limite, negará a própria existência de raças e grupos raciais no Brasil. São inúmeras as passagens em Brancos e Pretos na Bahia onde casos de discriminação racial são descaracterizados enquanto tais e reinterpretados como formas de discriminação de classe e, no prefácio à $2^{\underline{a}}$ edição brasileira, em 1966, num rompante nitidamente anacrônico, escreverá: "É possível [...] que ao descrever as relações sociais no Brasil, o próprio termo 'raça' deva ser posto de parte." Para arrematar mais adiante, inebriado por essa lógica conceptual:

Se, do ponto de vista sociológico, não há no Brasil grupos estritamente raciais, também não há sequer grupos de cor, ao menos no sentido cientifico do termo 'grupo'; ou se houver, serão ajuntamentos de configuração amorfa e instável. (Pierson, 1971:39)

\section{MARVIN HARRIS}

Em Harris, trinta anos depois de Pierson, a tese de que a discriminação existente no Brasil é de classe e não de raça é mais refinada. Para entendê-la em todas as suas nuanças é mister, todavia, lembrar preliminarmente que Harris se coloca contra duas teses clássicas que procuraram anteriormente explicar o teor não conflitivo das relações raciais no Brasil e o teor gradualista de sua classificação racial. A primeira é de que tal especificidade seria devida à colonização portuguesa; a segunda a de que,

2 "Existiu sempre um forte preconceito discriminador das raças, que se era tolerante e muitas vêzes se deixava iludir, fechando os olhos a sinais embora bem sensíveis da origem racial dos indivíduos mestiços, nem por isso deixou de se manter, e de forma bem marcada, criando obstáculos muito sérios à integração da sociedade colonial num conjunto se não racial, o que seria mais demorado, pelo menos moralmente homogêneo" (Prado Júnior, 1965:272). 
contraria ou complementarmente, fosse devida ao tipo de regime escravista que se desenvolveu no Brasil.

De fato, teorias que se apoiam numa pretensa miscibilidade dos portugueses e na particularidade do seu ethos, como as avançadas por Gilberto Freyre e, explícita ou tacitamente, absorvidas por Pierson e Azevedo, estão prenhes, como demonstrou recentemente Araújo (1995), de um neolamarckismo mal disfarçado. Opondo-se a essas teorias, Harris, ao contrário, baseia-se na ciência biológica contemporânea para rejeitar por completo a idéia de "raça" biológica. Ele segue rigorosamente a formulação de que as únicas raças existentes seriam sociais.

Do mesmo modo, Harris procura desmontar a idéia de que o tipo de escravatura na América do Norte fosse diferente daquele da América do Sul ao ponto de poder explicar as diferenças na forma de classificar e interagir racialmente.

Para Harris, portanto, as diferenças de situações raciais deviam-se a diferentes padrões culturais desenvolvidos nas Américas a partir de processos históricos complexos, envolvendo uma multiplicidade de determinantes e de condicionantes de ordem econômica, demográfica, política, social e propriamente cultural. No que respeita às diferentes formas de classificação racial resultante do contato entre europeus e africanos na América, haveriam três grandes tipos de classificação: (1) aquele prevalecente no Caribe dos anos cinqüenta, onde se formou uma camada intermediária de mestiços entre brancos e negros; (2) o sistema bipolar norte-americano que segundo Harris deve-se a uma regra de traçar a descendência que ele chamou de hipodescendência, ${ }^{3}$ e, finalmente, (3) o sistema brasileiro, que se caracterizaria pela ausência de regras de descendência.

Ora, ao nomear o sistema bipolar de "hipodescendência", Harris deixa à mostra a perspectiva política que adota em sua caracterização. A hipodescendência é claramente uma estratégia de dominação social, política e cultural que se poderia chamar propriamente de estratégia étnico-racial. Ou seja, o grupo dominante reproduz sua dominação através de uma ordem racial bipolarizada, onde uma parte considerável dos grupos sociais e étnicos subalternos são incluídos em seus privilégios raciais (enquanto brancos), e outra parte considerável é excluída juntamente com todos os seus mestiços (enquanto negros ou não brancos).

No Brasil, é tese sustentada por Harris, a discriminação de classe mostrou-se historicamente suficiente para manter os privilégios sociais e raciais dos dominantes sem que esses precisassem apelar diretamente para uma estratégia étnico-racial. A construção social da raça teria se limitado, portanto, a um gradiente valorativo branco-preto onde o branco polarizaria os valores positivos, restando ao negro os valores negativos. Tal construção racial seria, portanto, capaz de gerar e alimentar preconceitos raciais, mas incapaz de sustentar discriminações raciais sistemáticas pela simples ausência de regras objetivas de pertinência grupal e de descendência racial. Sem ser, pois, o paraíso racial que sugerem as idéias de Donald Pierson, o Brasil seria, ainda assim, uma sociedade onde as discriminações seriam propriamente de classe e não de raça.

É nesse ponto do argumento que Harris recupera e absorve as observações tanto de Pierson, quanto de Harry Hutchinson, de Charles Wagley e de Thales de Azevedo sobre

3 “Hypo-descendência significa filiação com o grupo subordinado e não com o grupo superordinado, de modo a evitar a ambigüidade de uma identidade intermediária" (Harris, 1964:56). 
as relações entre classes e cor, status e cor. A cor (a aparência física) seria um componente importante, mas não exclusivo, nem mesmo o mais importante da estratificação das classes sociais.

A sua leitura de Thales de Azevedo é, entretanto, uma leitura pobre, que não apreende a novidade teórica introduzida por esse.

\section{THALES DE AZEVEDO}

Dezesseis anos depois de Donald Pierson, entre 1951 e 1952, Thales de Azevedo conduz em Salvador, financiado pela UNESCO, o segundo estudo empírico sobre relações raciais na Bahia. Publicado em francês em 1953, As Elites de Cor ganha sua primeira edição em português em 1955 (Azevedo, 1955).

Do ponto de vista teórico, o estudo pouco inova em relação à Pierson, a quem, de fato, toma emprestado a tese de que o Brasil é uma "sociedade multirracial de classes". Do ponto de vista etnográfico, entretanto, o ensaio inova muito ao constatar e documentar a importância do status atribuído, principalmente a origem familiar e a cor, sobre o status adquirido, como aquele proveniente da riqueza e da ocupação. Thales constata, por exemplo, que, entre os diversos caminhos de ascensão social usados pelas pessoas de cor, em sua imensa maioria mulatos, é a educação - e as profissões liberais, por seu intermédio - o caminho mais comumente usado e de resultados mais seguros. O comércio era uma via quase que inexistente, o esporte - principalmente o futebol - uma via ainda incipiente e limitada pela profissionalização incompleta; a burocracia e a carreira militar eram rotas de ascensão curta; os casamentos inter-raciais, por fim, eram limitados em grande parte aos casais de cores mais próximas. Nesse último caso, Thales constata como a matrifocalidade (a tendência dos jovens casais localizarem-se sob a órbita de influência da família da mulher) diferencia as possibilidades de ascensão dos homens e das mulheres negras. Enquanto os negros e mulatos, quando bem-educados ou bem-sucedidos financeiramente, poderiam fazer casamentos com brancas empobrecidas, trocando assim posição econômica e social (riqueza e cultura) por prestígio social (ingressar numa família branca), as negras e as mulatas dificilmente poderiam atrair brancos empobrecidos pois não tinham nem prestígio social para oferecer (tais homens se "enegreceriam") nem riqueza, dadas às barreiras de gênero para o desempenho econômico. Às mulheres mestiças e negras, portanto, restava a concubinagem.

Enfim, Thales de Azevedo constata, em 1953, que são as redes pessoais, as boas maneiras e as etiquetas aristocráticas - dependentes ao fim e ao cabo da origem familiar - e a "qualidade" das pessoas (isto é, a sua cor) os principais veículos ou principais obstáculos à sua ascensão na sociedade baiana. Mas, embora etnograficamente registrados, o preconceito e a discriminação existentes são acomodados no esquema teórico delineado anteriormente por Pierson e interpretados como baseados principalmente em distinções de classe.

Será apenas alguns anos mais tarde, num pequeno artigo publicado em 1956, que Thales romperá essa limitação teórica. O modo como o fará é simples, pois tomará emprestado à sociologia alemã de Tönnies e Weber as categorias de classe e de grupos de prestígio, ou estamentos, para referir-se à estratificação dos grupos de cor, aplicando-as à 
Bahia da mesma maneira que Lloyd Warner havia anteriormente feito com as categorias de classe e casta em referência ao sul dos Estados Unidos.

A inovação de Thales consiste justamente em teorizar a transição do Brasil colonial, arcaico, para um Brasil moderno, capitalista em termos da passagem de uma sociedade de status para uma sociedade de classes, indicando como a associação entre status e cor permanecia incólume nessa transição.

Assim é que, introduzindo os grupos de status da velha Bahia, Azevedo nos diz que:

Efetivamente o conceito sociológico que melhor explica a estratificação da nossa sociedade colonial é aquele de status, que para Tönnies consiste em estamentos nos quais os individuos se classificam por atributação de posições, independente de suas aptidões pessoais, como clero, nobreza, povo, os estados do ancien régime. O conceito de status contrasta com o de classes, que são não-hereditárias e têm como referência as aptidões e realizações individuais especialmente de ordem econômica, educacional, além de pressupor permeabilidade dos estratos e, pois, mobilidade social vertical. (Azevedo, 1966:31)

Thales começa por caracterizar a sociedade colonial como dividida em dois grupos de status principais, brancos e negros, ou senhores e escravos, intermediados por um estrato ocupacional e socialmente desqualificado chamado "o povo". Se com a Abolição os negros foram incorporados ao "povo", a dissolução gradativa da hierarquia de status e o desenvolvimento de uma sociedade de classes irá dar espaço para o surgimento de uma camada intermediária nova, da qual emergirão mais tarde as classes médias.

Analisando a sociedade baiana dos anos 50, Thales irá teorizar justamente a convivência simbiótica dessas duas hierarquias - a de status e a de classe - numa sociedade em transição. A primeira divide a sociedade em classes alta, média e baixa; a segunda continua dividindo-a em brancos e negros. No seu modo de entender,

Enquanto que os grupos alto, intermediário e baixo funcionam como verdadeiras classes, permeáveis à mobilidade vertical especialmente entre os estratos contiguos, uma linha de distinção separa mais nitidamente os dois grupos de status e prestígio constituídos, de um lado, pelo agregado das classes alta e média e, de outro lado, pela classe baixa. É assim que a classe média está muito mais distante da 'pobreza' do que da elite, tanto em seus mores, como em seus privilégios. As discriminações mais visíveis e as tensões mais manifestas são as que se operam entre esses grandes grupos. (Azevedo, 1966:38-39)

Thales de Azevedo foi assim um dos primeiros a teorizar a sobreposição na estrutura social brasileira de duas hierarquias: a primeira, uma ordem econômica de classes sociais, baseada em relações sociais abertas e de mercado, onde dominam os contatos categóricos; e a segunda, uma ordem bipolar de status e prestígio, demarcada principalmente por marcas adscritas como "cor" e origem familiar, onde imperavam os contatos primários e simpáticos permitidos por uma rede de relações pessoais.

Esses dois grupos de prestígio, remanescentes da ordem escravista, podiam ser indistintamente denominados como "brancos" ou "ricos" o primeiro, e "pretos" ou "pobres" o segundo. Na caracterização de Azevedo, "brancos" eram não apenas os ricos mas também a classe média mestiça (morena ou mulata) e letrada (com nível de educação médio correspondente ao secundário). "Pretos" eram os pobres e iletrados, ainda quando de cor bran- 
ca ou clara. Azevedo dotou assim, de modo original, as designações raciais brasileiras de um fundamento estrutural, tratando-as não mais como denominações biológicas, mas como nomes de grupos de prestígio. Explicitava assim o significado sociológico do velho ditado, também típico-ideal, de que "branco pobre é preto e preto rico é branco."

Acrescente-se que, para Azevedo (1966:42), a ordem estamentária no Brasil era tão forte que era ela que delimitava a ordem competitiva. As desigualdades entre "brancos" e "pretos" estavam, para Azevedo, reguladas por essa ordem estamental através de mecanismos embutidos no sistema educacional, no mercado de trabalho, no sistema jurídico e na ordem política. Maneiras de falar e vestir, privilégios jurídicos e políticos, universos religiosos e estéticos separavam "brancos-ricos" de "pretos-pobres". Aqueles que cruzavam essa barreira estamental perdiam, por assim dizer, a sua "cor" original ou fenotípica para "embranquecer" ou "empretecer", conforme o caso.

Thales de Azevedo, portanto, fiel ao texto de Tönnies, emprega a categoria de status como categoria de estrutura social (com o mesmo estatuto de classe e casta), e não apenas como simples categoria de interação social, ao modo como o faziam tanto os sociólogos da chamada Escola de Chicago, quanto os sociólogos estrutural-funcionalistas que seguiam as trilhas abertas por Talcott Parsons. É minha opinião que, ao empregá-la dessa maneira, Thales de Azevedo encontrava o terreno teórico onde se poderia propriamente teorizar a dureza, a rigidez e a importância das distinções de cor no Brasil. Só, portanto, a percepção do status como fenômeno de estrutura permite a formulação radical de que:

Da observação da sociedade da Bahia parece que se pode induzir que o status resulta de uma combinação de fatores como nascimento e tipo fisico, que se deixam modificar, até certo ponto, pela fortuna, pela ocupação e pela educação. $O$ status de nascimento e a cor limitam a distância social que se pode percorrer no processo de mobilidade vertical, quaisquer que sejam os demais elementos condicionantes. (Azevedo, 1966:42)

É verdade, porém, que Thales de Azevedo no decorrer do texto, como também fazia Weber, emprega a categoria de status em dois sentidos, referindo-a tanto à estrutura quanto à interação sociais, e admitindo que as classes também formavam grupos de status. Isso, de certo modo retira um pouco da força de sua novidade teórica, tornando-a invisível para autores posteriores.

Do mesmo modo, a radicalidade da formulação de Thales não inibe o seu otimismo quanto ao futuro das relações raciais no Brasil posto que, na sua formulação, a sociedade estamental baiana estaria rapidamente cedendo espaço a uma sociedade de classes, no sentido weberiano correto, qual seja, o de uma sociedade onde a distribuição de poder ocorre primordialmente na ordem econômica, a qual passa a delimitar também o status ou prestígio social dos indivíduos. Essa tese não só aproxima Thales Azevedo de Pierson, fazendo-o ceder, portanto, a radicalidade das suas conclusões diante da tendência que anuncia, mas permite que autores como Harris tenham ignorado totalmente a solução teórica proposta por Thales nos anos 50.

Ao resenhar o ensaio de Thales de 1955, Marvin Harris (1964:61) irá dizer:

Esta discriminação de classe foi recentemente sumariada por Thales de Azevedo para a sociedade da Bahia. Dr. Azevedo encara a hierarquia social baiana como consistindo de três classes, com a clivagem social mais importante incidindo entre os grupos médio e inferior... (Harris, 1964:61, ênfase adicionada) 
Ou seja, Harris retraduz o texto de Thales para a sociologia da Escola de Chicago, assimilando ilegitimamente a clivagem estamental apontada por Thales à estrutura de classes. Perde, com isso, o conceito de grupos de prestígio, confundindo-o ao de classes sociais.

Será Florestan Fernandes (1965) quem irá desenvolver essas idéias embrionárias de Azevedo em algumas passagens auspiciosas de $A$ integração do negro na sociedade de classes. Retomando as idéias de Caio Prado Jr., por exemplo, Fernandes (1965:193-4) interpreta o "preconceito de cor" como um resquício da sociedade escravocrata, cuja função na ordem capitalista seria deletéria. No período de transição para o capitalismo, o preconceito teria a única função de resguardar as distâncias de uma hierarquia estamental já superada em termos de seus fundamentos econômicos.

De qualquer modo, acredito que se pode estabelecer firmemente a partir daquele pequeno ensaio de Azevedo, aparecido em 1956, a tendência nas ciências sociais brasileiras de teorizar as desigualdades sociais como sendo também desigualdades de cor. Isso porque em Thales os grupos de status, mais que classes, são grupos de cor, basea-
dos na ascendência familiar e racial.

\section{A ATUALIDADE DAS IDÉIAS DE THALES}

As intuições de Azevedo parecem, grosso modo, corretas em termos da relação que estabelecem entre ordem racial e hierarquias sociais. Contudo, o tempo se encarregou de mostrar que elas estavam erradas em dois pontos cruciais: primeiro, a ordem estamental (de status), ainda que historicamente tenha nascido e se nutrido do escravismo, não ficou restrita a essa formação social e econômica, tendo sido preservada, e se ampliado em termos absolutos, até os nossos dias; segundo, a ordem capitalista, longe de prescindir do "preconceito de cor", parece ter feito dele um dos seus principais mecanismos de reprodução de desigualdades sociais. De tal modo, que é naquele agrupamento que Azevedo chamara de "pobreza" há quarenta anos atrás, e que hoje é mais comumente chamado de
"excluídos", que se encontram os pretos.

Para efeito das investigações contemporâneas, todavia, continua frutífera a hipótese interpretativa segundo a qual os grupos de cor brasileiros representam antes de tudo a segmentação da sociedade brasileira em dois blocos contíguos mas estranhados entre si: elite e povo, ricos e pobres, cidadãos e excluídos, brancos e negros. Em outros termos, que o racismo e o "preconceito de cor" sejam formas racializadas de naturalizar a segmentação da hierarquia social. A racialização dessa hierarquia pode inclusive ajustar-se, segundo as regiões e o tempo histórico, para prover sucedâneos simbólicos aos "negros" como são, no sudeste brasileiro, os "baianos", os
"paraíbas" e os "nordestinos".

No entanto, como poderia uma classificação racial contínua como a cor estar simetricamente associada a uma segmentação estamental discreta e bipolar? A solução desse paradoxo só pode ser encontrada pela investigação empírica. Mas podemos adiantar ao menos que esse paradoxo só pode ser desfeito se a classificação gradualista de cor estiver associada, em certos aspectos-chaves das desigualdades raciais, como posição na estrutura ocupacional ou de rendimentos, a uma bipolarização entre "brancos" e "não brancos", como apontaram Silva \& Hasenbalg (1992), ou a uma bipolarização "negros" e "não negros", como apontaram Castro \& Guimarães (1993). 
Isso significa, ao mesmo tempo, teorizar sobre as conseqüências da segmentação estamental para o sistema de classificação racial no Brasil. Termino, portanto, esse texto alinhavando duas observações, ainda preliminares, sobre como estamentos e denominações raciais podem interagir no Brasil.

Em primeiro lugar, um contínuo de denominações raciais buscará representar as posições intermediárias entre os dois pólos, "branco" e "preto", encaixando a diversidade de situações e das combinações possíveis entre critérios raciais e sociais.

Ademais, se é verdade que a denominação da cor é traduzível imediatamente em termos de status e posição social haverá então uma discrepância entre autoclassificação (emic) e classificação fenotípica por terceiros (etic), a primeira mostrando uma tendência de embranquecimento. É exatamente isso que Nelson do Valle Silva (1994) verifica: a autoclassificação censitária (branco, pardo e preto), por correlacionar cor fenotípica e "cor social", acaba por sobreavaliar as desigualdades raciais no Brasil. Isto porque os mestiços "ricos" tendem a se declarar "brancos" e a diferença de status entre os que se definem "pardos" e "pretos" tende a diminuir, pois nenhuma das duas é uma denominação positivamente valorativa.

Em segundo lugar, por se tratar de uma segmentação cujos limites simbólicos, isto é, as marcas de status e de prestígio são cada vez mais ambíguos, posto que sujeitos à manipulação intensiva, é de se esperar que as denominações raciais se tornem cada vez mais dúbias assim como se increspe a luta por denominações mais positivas. Assim, "moreno" passa a agrupar desde o branco de tez queimada e cabelos pretos até as pessoas de cor em posições sociais de destaque. Não surpreende que instados a se classificar entre três denominações (branca, morena e preto) $63 \%$ dos entrevistados de Harris et al. (1993) se autoclassifiquem na rubrica "moreno". Essa é uma denominação positiva para todos que tenham algum grau de mestiçagem e simboliza ademais a nacionalidade brasileira. Dadas essas opções, provavelmente se identificam com "pretos" apenas aqueles que estão inescapavelmente na "pobreza" e como "brancos" apenas aqueles que fazem questão de pertencer às elites.

Quando, no entanto, a opção dada retira dos mestiços qualquer possibilidade de se autoclassificarem positivamente, como é o caso da classificação em "brancos", "pardos" e "pretos", cresce o número de "brancos" e de "pretos" simultaneamente. A razão mais plausível para isso parece ser uma assimetria no uso do prestígio social: alguns utilizam o sentido lato, social de "branco" para se incluírem com legitimidade, outros utilizam o sentido estrito, fenotípico de "preto" ou "pardo" para se incluírem sem pejo.

\section{REFERÊNCIAS BIBLIOGRÁFICAS}

ARAÚJO, R. B., 1995. Guerra e Paz: Casa-Grande \& Senzala e a Obra de Gilberto Freyre nos anos 30. Rio de Janeiro: Editora 34.

AZEVEDO, T., 1966. Classes e Grupos de Prestígio - Cultura e Situação Racial no Brasil. Rio de Janeiro: Civilização Brasileira (publicado originalmente em 1956 nos Arquivos da Universidade Federal da Bahia, no 5. Salvador: Faculdade de Filosofia; republicado em 1959 nos Ensaios de Antropologia Social. Salvador: Progresso).

AZEVEDO, T., 1955. As Elites de Cor, um Estudo de Ascensão Social. São Paulo: Cia. Editora Nacional (1 a edição em francês, 1953). 
CARVALHO, R., 1988. Aspectos da Influência Africana na Formação do Brasil. Novos Estudos Afro-Brasileiros, Recife: Massangana (1

CASTRO, N. \& GUIMARÃES, A. S. A., 1993. Desigualdades raciais no mercado e nos locais de trabalho. Estudos Afro-Asiáticos, 24: 23-60.

CUNHA, E., 1973 [1906]. Os Sertões. São Paulo: Cultrix/MEC.

FERNANDES, F., 1965. A Integração do Negro na Sociedade de Classes. São Paulo: Cia. Editora Nacional. 2 vols.

HARRIS, M., 1964. Patterns of Race in the America. New York: Walker and Company (edição brasileira: Padrões Raciais nas Américas. Rio de Janeiro: Civilização, 1967).

HARRIS, M. \& KOTAK, C., 1963. The structural significance of Brazilian categories. Sociologia, 25: 203-208.

HARRIS, M.; CONSORTE, J. G.; LANG, J. \& BYRNE, B., 1993. Who are the whites? Imposed census categories and the racial demography of Brazil. Social Forces, 72: $451-462$.

KROEBER, A. L., 1970. Castas. In: Estudos de Organização Social (D. Pierson, org.), pp. 413-418, Rio de Janeiro: Martins Fontes (originalmente verbete da Encyclopaedia of the Social Sciences, vol. III, 254-56).

MYRDAL, G., 1944. An American Dilemma. New York: Harper and Brothers Publishers.

PIERSON, D., 1971. Brancos e Pretos na Bahia-estudo de contacto racial. São Paulo: Nacional (1ª edição americana 1942, 1a edição brasileira 1945).

PIERSON, D., 1975. Teoria e Pesquisa em Sociologia. São Paulo: Melhoramentos (1ª edição, 1945).

PRADO JÚNIOR, C., 1965. A Formação do Brasil Contemporâneo - Colônia. Rio de Janeiro: Brasiliense (1 1 edição, 1942).

SILVA, N. V., 1994. Uma nota sobre 'raça social' no Brasil. Estudos Afro-Asiáticos, 26:67-80.

SILVA, N. V. \& HASENBALG, C., 1992. Relações Raciais no Brasil Contemporâneo. Rio de Janeiro: Iuperj/Rio Fundo Editora.

VIANNA, O., 1959 [1932]. Raça e Assimilação. Rio de Janeiro: José Olympio.

WARNER, W. L., 1970. Casta e classe. In: Estudos de Organização Social (D. Pierson, org.), pp. 419-423, Rio de Janeiro: Martins Fontes (publicado originalmente em 1941, como parte da Introdução à Deep South de Davis, A.; Gardner, B. B. \& Gardner, M. R.). 


\section{ROGER BASTIDE, PAISAGISTA \\ Maria Lúcia de Santana Braga}

\section{APRESENTAÇÃO}

Roger Bastide foi um paisagista. Pintou pequenas e grandes paisagens do Brasil. Procurou conhecer, enquanto poeta, psicanalista, sociólogo e antropólogo, um país em muitos aspectos diferente do seu. Nascido no final do século passado na França, mais exatamente em Nîmes, sul do país, foi profundamente marcado por esta região. Isto se refletiu em grande medida em sua trajetória no Brasil. Aos 40 anos, ainda no início de sua carreira acadêmica, chegou a São Paulo. Nesse período, vários professores estrangeiros já tinham vindo integrar o corpo docente das universidades recém-criadas.

Bastide, ao contrário de vários cientistas sociais estrangeiros, não apenas se restringiu à coleta de dados para a sua tese de doutorado, seus livros e artigos. Interessou-se pelo país e particularmente em sua longa relação com seus alunos e colaboradores na Faculdade de Filosofia, Ciências e Letras da USP transmitiu todo o seu desejo em envolver-se com o mundo brasileiro. Talvez por isto não tenha sido reconhecido conforme a sua estatura intelectual. Ao voltar à França nos anos 50, já tinha publicado inúmeros livros, artigos e realizado diversas pesquisas. Apesar disto não era um intelectual requisi-
tado naquele período como, por exemplo, Claude Lévi-Strauss.

O título deste artigo foi escolhido tendo como referência um ensaio de Bastide sobre o escritor Machado de Assis. Intitulado "Machado de Assis, paisagista", publicado em 1940, o ensaio elaborado por Bastide teve o propósito de combater as críticas feitas a Machado de Assis em relação a sua pretensa falta de nativismo. Bastide mostra que o escritor, em maior grau que vários outros, viu o País com olhos de brasileiro, e não com olhos de estrangeiro que somente conseguem ver o exotismo do Brasil.

Privilegiamos em nossa análise um tema que sempre chamou a atenção de Bastide: as relações raciais no Brasil. Em seus estudos sobre as religiões africanas, a interpenetração das civilizações brancas e negras, o candomblé, o preconceito racial, entre vários outros, ressalta-se a constante preocupação metodológica de Bastide. Sempre atento e sensível à escolha do melhor instrumento para o entendimento de fenômenos muito complexos, teve como principal projeto acadêmico e intelectual o desenvolvimento de métodos adequados que levassem a descobertas originais.

Conforme verificaremos no decorrer do artigo, o projeto acadêmico e intelectual de Roger Bastide apoiou-se fundamentalmente em sua preocupação metodológica. Isto fica bastante claro em suas pesquisas e análises sobre as relações raciais no Brasil dos anos 40 e 50 que causaram grande impacto. Consideramos que tanto Machado de Assis como Roger Bastide tinham a qualidade de ver o Brasil com olhos brasileiros. E conseguiram pintar sólidas paisagens e retratos de um país plural. 


\section{RETRATOS E PAISAGENS DO BRASIL}

Em 1938 , momento em que chegou ao Brasil, Roger Bastide encontrou uma profusão de temas e interesses nos quais poderia se dedicar em suas pesquisas.

No primeiro momento, deu continuidade aos seus estudos sobre a religião iniciados ainda na França. Paralelamente, dedicou-se nos primeiros anos em aprofundar suas pesquisas sobre a arte, a literatura e o folclore, tomando agora como campo empírico as manifestações culturais brasileiras. Podemos afirmar que durante os dezesseis anos em que esteve no Brasil, Bastide preocupou-se em conhecer tudo que estava ao seu alcance ou o que lhe despertava interesse, não se atendo somente ao que determinava os cânones cien-
tíficos da época.

Inclusive, chamou a atenção em seus estudos para o que Robert Nisbet (1979) descreveu como a unidade essencial da arte e da ciência. Entre a arte e a ciência existe uma profunda afinidade que está presente em seus temas e estilos comuns de estudo:

Sociologia y arte están estrechamente ligados. No necesitamos más que volvernos hacia las historias de la literatura, estética y artes en general para hallarmos en presencia de temas y objetivos que ostentan un sorprendente parecido con aquellos que acabo de señalar en la sociologia. La relación del individuo con la aldea, el pueblo y la ciudad; la relación entre ciudad y campo; la influencia de la autoridad, o de su crisis, sobre la vida humana; la búsqueda de lo sagrado, la tortura del anonimato y de la alienación: tudo esto puede contemplar-se en las novelas, dramas, poemas y cuadros, incluso en las composiciones musicales de todos los tiempos, con la mesma vivacidade que tiene en las obras de los sociólogos, desde Tocqueville y Marx en ade-
lante. (Nisbet, 1979:12)

Segundo Nisbet (1979), o mais significativo é o ato criador presente tanto na arte como na ciência que consiste no descobrimento, na iluminação ou invenção no momento de criação da obra artística ou científica. Nisbet considera que a renovação e a revitalização da sociologia somente podem ocorrer se forem superados alguns erros conceituais. Em primeiro lugar, tanto o artista como o cientista procuram conhecer a realidade, explorar o desconhecido e interpretar o mundo humano e físico. Não é possível permanecer com a distinção que determina como função primordial da ciência a investigação da rea-
lidade, a busca da verdade e da arte, a manifestação do belo, usualmente responsável por
experiências de segunda mão. experiências de segunda mão.

Assim como a ciência, a arte preocupa-se com o conhecimento mais elaborado do mundo. A arte tem sido um instrumento essencial da consciência científica. Os pensadores mais eminentes das ciências sociais nos últimos dois séculos perceberam de imediato
a afinidade entre a arte e a ciência.

Outra verdade comumente propagada na sociologia refere-se à crença de que o objetivo de toda pesquisa é o progresso da teoria sociológica. ${ }^{1}$ A manifestação mais negativa dessa crença é a veneração em torno dos grandes sistemas teóricos como se afirma
abaixo: 
Es una verdad que no debiéramos cansarmos de repetir que ninguna obra auténticamente buena o fecunda en la historia de la sociología se escribió o concibió como medio de hacer avanzar una teoría, general o particular. Cada una de ellas se escribió en respuesta a un problema o desafio intelectual singular y apremiante planteado por el entorno intelectual inmediato. (Nisbet, 1979:37)

Mas quais são os temas e estilos comuns à arte e à sociologia? Nisbet (1979) aponta quatro grandes temas básicos que são predominantes na sociologia e, por sua vez, na arte. São os seguintes: o indivíduo, a ordem, a liberdade e a mudança. Retratar as mudanças sociais ocorridas na Europa, os principais atores e as mudanças ensejadas por estes, tudo isso foi realizado tanto pelo artista como pelo cientista ou sociólogo nos séculos XIX e XX. Tanto os sociólogos como os artistas elaboraram paisagens e retratos de grande impacto nos últimos dois séculos.

A paisagem cultural e social tem sido há muito objeto de trabalho do sociólogo e do artista. Nisbet (1979), inclusive, afirma que as paisagens sociais do século XIX apareceram antes nas obras dos poetas, pintores e literatos para só em seguida surgirem nas obras de pensadores sociais como Weber, Marx, Durkheim e Simmel. Entre as muitas paisagens sociais presentes nas obras desses autores podemos citar as massas, o poder, as fábricas e a metrópole. Os retratos, por sua vez, também ocuparam um importante espaço na compreensão e descrição dos principais personagens presentes nos processos sociais, quais sejam: o trabalhador, o burguês, o burocrata e o intelectual. Apesar de muitas vezes ressaltar os traços individuais, o retrato possibilita descrever os papéis sociais predominantes.

Estas idéias já estavam presentes nos seus primeiros estudos de Bastide realizados no Brasil. Bastide não era adepto de uma sociologia restrita e sem contato com o mundo a sua volta. Ao contrário, sempre defendeu o uso de métodos e teorias diversas, a interlocução constante com outras áreas do conhecimento e outras formas de expressar este conhecimento. A arte foi uma dessas áreas a qual Bastide mais se aproximou e descobriu afinidades.

O que pretendemos explorar melhor nesse momento são as paisagens e retratos elaborados por Bastide sobre a situação racial no Brasil. Quais foram os principais instrumentos utilizados por este? Consideramos que o sociólogo francês, desde o início de sua estadia no Brasil, procurou refinar seus métodos e utilizar os conhecimentos teóricos que melhor iluminassem o fenômeno social em questão. Para nós, a introdução elaborada por Bastide em 1972, dois anos antes de seu falecimento, para a reedição de seus primeiros estudos afro-brasileiros realizados nas décadas de 40 e 50 , mostra de forma muito clara como ocorreu a formulação e execução de seu projeto acadêmico e intelectual.

Naquele momento, ao realizar um balanço dos estudos afro-brasileiros e de sua contribuição à temática, esclarece que o principal objetivo era metodológico. Por outro lado, o seu interesse pelo candomblé e pela descoberta dos seus significados fundamentava-se na busca de novas perspectivas que estão presentes tanto em seus escritos no Brasil como naqueles elaborados na França. Também ressalta as modificações surgidas a partir da industrialização e urbanização aceleradas nos anos 60 que mudaram substancialmente a superestrutura desde a elaboração de seus primeiros estudos afro-brasileiros.

No entanto, estes ainda trazem contribuições originais que possibilitam novos estudos, com a retomada naquele momento da pesquisa afro-brasileira, que em sua ótica en- 
contrava-se em crise desde que os problemas culturais foram substituídos pelas preocupações dos sociólogos com o desenvolvimento econômico e social. Indo contra a imagem estereotipada, racista e folclórica dos negros brasileiros, Bastide dedicou-se a um projeto mais amplo definido por ele como "o estudo dos negros brasileiros enquanto criadores de cultura". Procurou realizar sua pesquisa mediante a compreensão total das manifestações culturais afro-brasileiras. Ou seja, produziu análises sobre a poesia, a literatura, a imprensa, as religiões, além de ter coordenado o Projeto UNESCO, responsável por um amplo mapeamento da situação do negro no município de São Paulo. E seus estudos demonstraram não somente a dualidade vivida pelos negros brasileiros, herdeiros de duas culturas, mas a criatividade dos mesmos em criar mecanismos e instrumentos de libertação segundo mostraremos mais adiante. Tendo em vista os limites deste artigo, destacaremos em seguida algumas das primeiras paisagens e retratos formulados sobre a
temática afro-brasileira.

\section{Um Retrato Poético do Negro Brasileiro}

Em sua obra A Poesia Afro-brasileira, publicada em 1943, consideramos que Bastide formula um retrato da situação do negro brasileiro mediante a análise das manifestações artísticas, no caso a poesia, desse segmento.

Nesta obra, Bastide utiliza-se do mesmo procedimento já presente nas suas obras produzidas na França, que consiste em analisar nas obras escritas a influência dos complexos religiosos. No Brasil, seu objetivo foi aplicar seu método na análise das influências raciais na poesia produzida pelos poetas negros. A psicanálise exerce um papel significativo em seu procedimento metodológico. No entanto, Bastide salienta que seu método se diferencia do psicanalítico pois procura explicar o inconsciente coletivo e não
o individual:

Procuramos a raça na trama da obra escrita. Para tanto não reconstituimos a posição do escritor no meio familiar, mas no meio social. Deste modo o nosso método se aproxima mais da sociologia do que da psicanálise propriamente dita. Nossa marcha é mesmo o inverso da dos discípulos de Freud. Estes geralmente não sabem quais são as origens do paciente; não só os complexos são inconscientes mas ainda se formam sem que ninguém saiba como. É preciso então tomar os últimos dados, os sonhos, os delírios, os desenhos, as associações livres, os comentários na penumbra do gabinete ou, no caso do escritor, a obra literária, a escolha dos assuntos, as imagens, as comparações ou metáforas, para reconstruir com todo esse material o que deveria ter sido a libido da criança e as coerções contra as quais teve de lutar. (Bas-

O ponto de partida do método reside nos dados reais observáveis a partir do meio exterior. O objetivo é abarcar a zona que se encontra entre o consciente e o inconsciente, isto é, a fronteira entre esses dois mundos. Apesar das analogias existentes entre o método psicanalítico e o seu, Bastide reafirma que é necessário definir com precisão as diferenças entre os dois para evitar determinadas confusões. Mesmo empregando o vocabulário psicanalítico, o que diferencia essencialmente as abordagens psicanalítica e sociológica consiste nas áreas de exploração: numa, o individual; noutra, o social.

Bastide, nos vários ensaios sobre a poesia afro-brasileira, realiza uma análise que é ao mesmo tempo literária, psicológica e sociológica. A partir desse enfoque, o intuito 
é entender a alma do negro e do mulato, o que é próprio e original do sangue africano na literatura brasileira. Tendo em vista que o objetivo da obra é traçar um quadro completo da poesia afro-brasileira, pretendemos analisar aqui somente os aspectos mais relevantes do estudo. Dados os limites deste artigo, circunscreveremos somente a dois dos poetas enfocados por Bastide: Gonçalves Dias e Cruz e Souza.

$\mathrm{Na}$ análise da poesia de Gonçalves Dias, geralmente, coloca-se que o poeta incorpora as três raças, sendo o legítimo representante de uma nova etnia. Segundo Bastide, Gonçalves Dias não encarna a etnia brasileira, como afirmam comumente, pois para isso seria preciso uma poesia sincrética e um modo africano de encarar o assunto. Um exemplo desse aspecto pode ser visto em dois temas específicos presentes na obra de Gonçalves Dias: a saudade e o amor. Na análise da saudade, Bastide procura caracterizar o que diferencia esta do banzo africano. A saudade, geralmente presente em Gonçalves Dias, é a da pátria e o banzo pode ser visto como a nostalgia do africano pelo seu país abandonado, que expressa mais a desintegração tribal do que a separação da pátria. Tal característica, que é a saudade como dor e o gosto pelo doer, o negro adquiriu na medida em que se aportuguesou. Nesse sentido, Gonçalves Dias pode ser enquadrado mais na tradição portuguesa do que na africana.

$\mathrm{O}$ amor é o segundo tema tratado. Entre os negros, este exprimiu mais uma reivindicação de cunho racial, enquanto Gonçalves Dias tomou outra vertente que foi a da valorização do sentimento amoroso. O poeta se afasta também nesse momento do que poderia ser uma poesia afro-brasileira ao falar do amor nos moldes brancos.

Em relação à Cruz e Souza, Bastide aponta no primeiro momento o aparente paradoxo que é o de um descendente de africanos ter sido o maior representante da poesia simbolista no Brasil, visto que o simbolismo é essencialmente nórdico e apoiado na filosofia platônica.

$\Lambda$ explicação inicial apresentada acredita que por ter Cruz e Souza nascido em Santa Catarina foi este influenciado pela colônia alemã lá existente. Tal explicação de imediato é rechaçada por Bastide porque outro poeta afro-brasileiro, Tobias Barreto, que se formou em condições distintas, também se inspirou nas mesmas fontes do simbolismo. Portanto:

explicação só pode ser encontrada numa análise do inconsciente racial, na vontade de mudar mentalmente de cor: é preciso clarear e o melhor meio é procurar a poesia ou a filosofia dos indivíduos que têm a pele mais clara, isto é, os povos do Norte. (Bastide, 1943:89)

A poesia de Cruz e Souza expressa a sua vontade de negar as suas origens africanas e o sonho de ser ariano. É somente a partir da análise do inconsciente que estas razões poderão tornar-se claras. Abolir as fronteiras que separam brancos e negros através da arte era o desejo de Cruz e Souza. Para isso, ele transfere o seu desejo para a poesia simbolista: o desejo de pertencer à raça branca, de ser um eleito. Conforme recorda Bastide:

Existe mesmo uma parte de sua obra que ilustra claramente a lei psicanalítica da 'transferência', estudada por Freud na elaboração do sonho. É quando o poeta relata o seu desejo de ver, visitar, partir para o país do norte, para as planícies nevadas ou geladas. A libido transfere do fim para os meios, mas trata-se sempre do mesmo desejo sexual, da mesma nostalgia que (ilberto Freyre descreveu entre os Portugueses morenos, da virgem de pele leitosa e de cabelos dourados. (Bastide, 1943:91) 
O objetivo de Cruz e Souza era esquecer a sua origem africana e ultrapassar a linha que separava brancos e negros. No entanto, Bastide também mostra de que forma a herança racial está presente na obra de Cruz e Souza. Isto ocorre na sua poesia que aborda a noite na qual concilia a influência simbolista com a racial. A noite é caracterizada, por um lado, como doce e boa, e por outro, como satânica e feiticeira. $\mathrm{O}$ aspecto que se torna relevante nesse momento é que quando Cruz e Souza pensa ter ultrapassado a linha de cor, ocorre, ao contrário, o reencontro com a África. A sua poesia noturna assume o seu lado mais africano, produzindo uma obra inédita que ultrapassa o simbolismo.

Em suas conclusões, Bastide afirma a existência de uma poesia afro-brasileira que, no entanto, não está inscrita de forma explícita:

Ela está, como a filigrana, inscrita na transparência do papel, na textura, na trama da obra escrita, no segundo plano dos sentimentos expressos e a sua música é ouvida em surdina, ressonância longínqua e sutil, a cada pausa do verso ou da estrofe. É preciso, pois, saber procurá-la, mas se quando escuta atentamente, se é recompensado por essa música que se mistura tão harmoniosamente à outra, que dá ao poema uma significação mais rica, uma beleza mais comovente ainda. (Bastide, 1943:129130)

O que fica patente nesta obra de Bastide é que este procurou mediante o estudo das obras literárias de vários poetas as manifestações de origem racial que geralmente não estão presentes no nível do consciente. Para encontrar a poesia afro-brasileira foi preciso utilizar "as técnicas de pesquisa do oculto, estabelecidas pela psicanálise, mas com a necessária transformação, pois não se tratava de atingir o individual, como o freudismo, mas, ao contrário, o coletivo" (Bastide, 1972:34). ${ }^{2}$ A psicanálise forneceu o instrumental necessário para a análise mais profunda dos textos e seus autores, inserindo-os em um contexto social e psicológico e não meramente estético.

\section{Uma Paisagem Sociológica: o Projeto UNESCO}

Em 1950, a UNESCO solicitou à Bastide uma ampla pesquisa sobre a situação em que viviam os negros em São Paulo. Em seguida Bastide convidou o seu assistente, Florestan Fernandes, que naquele momento estava concluindo a sua tese de doutoramento, para se incorporar ao projeto.

Em colaboração com a Revista Anhembi, dirigida por Paulo Duarte, foi realizado um inquérito de grande envergadura o qual procurou conhecer a real situação racial, particularmente no município de São Paulo. Conforme ressaltou Paulo Duarte (1955:8), a preocupação principal concentrou-se na realização de um "ensaio sociológico sobre as

Bastide lembra na reedição dos estudos sobre a poesia afro-brasileira, feita em 1973, que esse ponto não foi bem compreendido por muitos críticos literários. No caso de Cruz e Souza, por exemplo, vários críticos preferiam considerá-lo como mero seguidor de Mallarmé, não encontrando qualquer significado mais profundo ou original em sua poesia. No entanto, Bastide (1973:34) reafirma: 'Talvez possam dizer-me que esse 'oculto' por mim procurado não passa de uma simples hipótese e eu responderia que Freud também ensinou-me que se deveria lançar uma hipótese quando estivesse ela já verificada pela convergência de todo um conjunto de associações livres. Ora, Cruz e Souza oferece nos seus poemas em prosa a possibilidade de proceder a uma confirmação de minha interpretação, ao confessar que desejava fazer uma música de branco, mas enganara-se - o tantã de seus ancestrais continuava a bater dentro dele". 
origens, as manifestações e os efeitos sociais do preconceito de cor no município de São Paulo". Bastide, coordenador do projeto, logo na introdução do ensaio publicado em $1955,{ }^{3}$ considera que, apesar do estudo tratar do problema da cor, é preciso relativizar e compreender que esses problemas raciais constituem momentos na vida dos negros e "que, no seu conjunto, a vida dos pretos nada oferece de uma perpétua tragédia" (Bastide'\& Fernandes, 1955:15).

A preocupação central do estudo foi mostrar a paisagem mais completa da situação racial em São Paulo. Para tanto, foram convidados intelectuais e organizações negras. Além disso, vários métodos e técnicas foram utilizados para ter acesso às manifestações raciais da população: aplicação de questionários, a técnica das entrevistas ocasionais, a técnica das entrevistas formais, a técnica das biografias ou histórias de vida e o método ecológico.

A pesquisa não se restringiu somente aos negros, mas abarcou os brancos, tanto as famílias tradicionais como os imigrantes. Também vários setores foram pesquisados: industrial, serviços e comercial. Além da análise sociológica presente nos vários ensaios, Aniela Ginsberg e Virginia Bicudo realizaram um estudo psicológico sobre as atitudes raciais entre os grupos infantis.

Vamos em seguida nos ater à análise dos dois ensaios elaborados por Bastide na âmbito da pesquisa, nos quais procuraremos ver de que forma o sociólogo francês contribuiu para uma compreensão maior do problema racial brasileiro. O primeiro ensaio trata das manifestações do preconceito de cor. $\mathrm{Na}$ análise das inúmeras respostas coletadas pela pesquisa, Bastide percebe várias contradições acerca da existência do preconceito tanto entre os negros como entre os brancos. No entanto, Bastide distingue também a presença de uma visão idealizada da democracia racial no Brasil. Isto significa que o preconceito não aparece de forma aberta, mas de modo encoberto:

Os estereótipos recalcados agem nas fronteiras indecisas do inconsciente, menos por construções sociais, um ritual institucionalizado, do que por repulsões instintivas, tabus pessoais. O negro, aliás, é eleitor, e os partidos politicos disputam os seus votos como os dos brancos. A opinião pública é sensivel ao bom nome do Brasil, a tudo o que poderia prejudicar a sua tradição de democracia. (Bastide \& Fernandes, 1955:124).

Desvendando os comportamentos sociais que não aparecem em primeira instância em uma suposta democracia racial, Bastide especifica que é necessário recorrer à análise da ausência de comportamentos para compreender as manifestações do preconceito racial. Com o intuito de traçar o mais amplo painel dessa situação, a análise é feita sobre as manifestações de diferentes grupos étnicos, das famílias tradicionais paulistanas, dos portugueses, dos sírios e dos italianos, dos grupos profissionais e abarcando assim todas as classes sociais.

Em todos os níveis, o preconceito racial não se apresenta explicitamente, mas na ausência de um sistema de reciprocidade nas relações entre brancos e negros. O negro é tratado afetuosamente mas basta que um estranho chegue na casa para que logo surja outro tom entre o patrão e o visitante (Bastide \& Fernandes, 1955:126).

Bastide detalha essa convivência ora afetuosa e sentimental, ora repulsiva, quando os negros são considerados preguiçosos, bêbados, insubordinados e desorganizados. Para 
Bastide, o preconceito de cor muitas vezes se aproxima do preconceito de classe, conforme argumenta em seu ensaio. O clima afetivo entre as raças criado pela tradição geralmente disfarça o preconceito racial. No trabalho, isto fica claro na rejeição de negros para ocupar determinadas funções. As expressões utilizadas nesse momento são polidas: "falta lugar", "o lugar acaba de ser preenchido", entre outras.

Bastide nos mostra as inúmeras barreiras encontradas pelos negros. Mas quais são os efeitos desse preconceito sobre os negros? No segundo ensaio, Bastide nos fornece algumas respostas a esse questionamento. Tendo em vista as diferenças existentes entre os próprios negros, duas atitudes são comumente assumidas principalmente entre os segmentos mais pobres. A primeira consiste no conformismo, na atitude passiva, na aceitação de sua situação de inferioridade racial e social. A segunda também aceita esta situação de inferioridade, mas assume uma atitude ativa em relação as suas possibilidades de ascensão social na sociedade de classes.

Já entre os negros pertencentes à classe média, a aceitação também ocorre, mas são utilizadas outras formas de tratamento, como a ironia e a paciência e não o confronto aberto contra a rejeição e a zombaria, características sempre presentes no preconceito. A resistência e a revolta contra o preconceito racial ocorrem geralmente entre os intelectuais e líderes que se preocupam com a organização dos negros para superar a discriminação, existentes desde a década de 20. Bastide mostra ainda a existência dos órgãos de fiscalização social, como a igreja e a polícia, que cumprem um significativo papel na manutenção do preconceito. Não é possível detalhar no âmbito desse artigo o manancial de informações e análises realizadas por Bastide nesses dois ensaios.

Apesar de não ter realizado uma análise exaustiva, acreditamos ter fornecido uma breve noção da riqueza dos estudos realizados por Bastide. Este pensador, bem como Florestan Fernandes e outros colaboradores que participaram do Projeto UNESCO (vide também Arruda, neste volume), propiciaram o conhecimento de uma paisagem brasileira que persiste em essência até o momento. $O$ inquérito coordenado na década de 50 por Bastide, no qual tornou-se claro "um preconceito que nem sempre ousa dizer seu nome" (Bastide \& Fernandes, 1955:159), permanece ainda extremamente atual.

No próximo tópico, detalharemos a construção do projeto intelectual de Bastide, dando especial atenção a sua formação, ao período brasileiro, ao envolvimento com os estudos afro-brasileiros e a sua abordagem metodológica, aspectos necessários para uma compreensão global do tema deste artigo.

\section{A CONSTRUÇÃO DO PROJETO INTELECTUAL DE ROGER BASTIDE $^{4}$}

\section{Formação e Ambiente Intelectual}

Os primeiros professores franceses que vieram integrar o corpo docente da Universidade de São Paulo chegaram em 1934, ocorrendo nos anos seguintes um fluxo intenso que somente foi interrompido em 1939 pela guerra na Europa.

O presente tópico foi melhor desenvolvido em Braga (1994). 
Ao analisar a presença dos professores estrangeiros no Brasil, o que geralmente aparece em primeira instância são as características que os unem e não as diferenças que os separam. A imagem geralmente feita sobre os professores, em especial os franceses, é a de que eram jovens em início de carreira à procura de oportunidades no Brasil. Entretanto, estes professores eram muito diferentes sob vários aspectos. Conforme Massi (1989), as diferenças podem ser encontradas em diversos níveis. Ou seja, nas suas trajetórias intelectuais, nas suas preocupações teóricas e metodológicas, nas suas relações com a sociedade brasileira, entre outras.

Roger Bastide aportou no Brasil em 1938 e só foi embora de forma definitiva em 1954. Nascido em Nîmes, sul da França, em $1^{\underline{0}}$ de abril de 1898, já estava com 40 anos quando chegou ao Brasil. Charles Beylier (1977), que elaborou uma tese de doutorado sobre a obra brasileira de Bastide, salienta, conforme informações de um antigo amigo do sociólogo, que este teria nascido em Anduze, o que explicaria a personalidade, e por conseguinte, vários aspectos da obra de Bastide. Este teria sido influenciado e marcado pela região francesa que foi local de muitas lutas entre católicos e protestantes. Maria Isaura Pereira de Queiroz (1983) também ressalta que Bastide foi criado em Anduze apesar de ter nascido em Nîmes, região das Cévennes, refúgio dos rebeldes protestantes, fato que o marcou profundamente.

Sua formação intelectual ocorreu boa parte fora de Paris. Licenciou-se em Filosofia em Grenoble em 1917 e concluiu a agregation em Filosofia em 1924. ${ }^{5}$ Foi, em seguida, professor nos liceus de Cahors (1924-1926), Lorient (1926-1928), Valence (1928-1937) e Versalhes (1938), onde apenas chegou a ser nomeado para logo partir para o Brasil (Massi, 1989:423; Pereira de Queiroz, 1983:44).

Os anos 10 e 20 constituem momentos de grande produção para a sociologia francesa. Bastide, apesar de não ter sido aluno dos grandes mestres daquele período, teve uma formação ampla e variada. Pereira de Queiroz (1983) inclusive ressalta que por ter se formado fora de Paris, Bastide não se enquadrou nas correntes dominantes e teve uma formação diversificada, incluindo a sociologia francesa, alemã, inglesa e norte-americana, além da antropologia, psicanálise e filosofia.

Bastide, assim como todos os autores que o influenciaram e os que foram seus contemporâneos, teve em Durkheim seu mestre maior. Somente na década de 20 houve de fato o surgimento de oposição a Durkheim. Os dois pensadores que representaram uma oposição direta à Durkheim e seus discípulos foram René Worms (1869-1926) e Gaston Richard (1881-1945). Estes se organizaram basicamente a partir da Revue Internationale de Sociologie fundada em 1893 e dirigida por René Worms, cujo caráter orientava-se para uma abordagem mais eclética na sociologia. Gaston Richard sucedeu Worms na direção da revista que encerrou as suas atividades em 1939. Gaston Bouthoul e Roger Bastide foram os mais destacados discípulos e colaboradores de Gaston Richard. Bastide, apesar de reconhecer a formação comum, calcada na sociologia de Durkheim, adotou desde cedo

5

A agregation constituía o primeiro titulo da carreira universitária, que habilitava para o ensino secundário, vindo em seguida o doctorat para o ensino superior (Massi, 1989:420). 
uma atitude mais crítica em relação à contribuição deste, preferindo assum ir uma orientação mais eclética. ${ }^{6}$

Gaston Richard foi o sociólogo em que Bastide se apoiou e se orientou para realizar tal escolha. Professor de ciências sociais na Universidade de Bordeaux, Richard elaborou vários estudos nos quais procurou debater aspectos ligados à definição do objeto e método da sociologia. O próprio Bastide, em artigo publicado em 1939, realizou um pequeno balanço sobre a contribuição de Gaston Richard à sociologia francesa. Segundo Bastide, ao se mencionar a sociologia francesa a associação imediata é com a escola de Durkheim ou a de Tarde. Em sua concepção, a sociologia francesa daquele período é muito mais complexa e rica, onde se destacam também autores como Gaston Richard. Três momentos podem ser distinguidos na sociologia richardiana. Na primeira fase, Gaston Richard dedicou-se ao estudo da autonomia humana, contrapondo-se a Espinas nessa discussão. Durkheim, nesta época, também não concordava com as concepções de Espinas, o que acabou por aproximá-lo de Richard.

Com a fundação do L'Année Sociologique, Durkheim convidou Richard para ser seu colaborador, principalmente em relação aos problemas de patologia social. A colaboração entre os dois pensadores durou muitos anos, segundo Bastide, pelo "cuidado de assegurar à sociologia a mais completa independência, o desejo de fazer dela uma ciência positiva e, por consequêencia, de desembaraçá-la da Filosofia" (Bastide, 1939:93). No entanto, concepções distintas sobre a liberdade e a autonomia humana levaram à separação de Durkheim e Richard. Por não concordar com o conceito de coerção coletiva de Durkheim, pois compreendia uma moral baseada na liberdade humana, Gaston Richard iniciou uma terceira fase em sua trajetória intelectual quando formulou a sua própria sociologia, que está contida principalmente em sua obra La Sociologie Générale et les Lois Sociologiques (Richard, 1912).

Nesta obra, Richard buscou respostas para a natureza do determinismo sociológico e da liberdade humana, retomando mais tarde essa mesma discussão em seus livros posteriores L'evolution des Moeurs, La Conscience Morale e La Loi Morale, les Lois Naturelles et la Loi Sociale.

Antonio Candido, ex-aluno e colaborador, apontou de forma clara a influência de Gaston Richard em Bastide:

O Bastide não era licenciado pela Universidade de Paris. Era [licenciado pela Universidade de] Bordeaux. A grande influência que ele recebeu foi do Gaston Richard. Gaston Richard é um sociölogo francês (...). A grande influência de Arbousse-Bastide era Durkheim. Roger Bastide, não. O Roger Bastide não era durkheimiano. Os sociólogos franceses eram durkheimianos. Os brasileiros eram superdurkheimianos. Ele dizia: eu recebi influência de Gaston Richard. O Gaston Richard era muito crítico em relação à Durkheim. ${ }^{7}$

Florestan Fernandes também salientou a importância de Gaston Richard na formação de Bastide e ao mesmo tempo destacou o caráter interdisciplinar e eclético da mesma:

Para outras informações sobre a sociologia francesa nas primeiras décadas deste século, particularmente no período entre 1920 a 1940, vide Heilbron (1985).

Depoimento concedido à autora em 26/05/94. 
Por exemplo, o Bastide, entre os sociólogos, ele preferiu Gaston Richard, mas ele não era um richardiano. Ao contrário, ele conhecia a antropologia inglesa, conhecia a etnologia francesa, conhecia todos os clássicos da sociologia, franceses, alemães, italianos. $^{8}$

Ou seja, Bastide teve uma formação intelectual diversificada que não se restringiu somente à sociologia francesa, mas abarcou as contribuições da sociologia de outros países da Europa como, por exemplo, a de Georges Gurvitch. Nascido na Rússia em 1894, Gurvitch após se iniciar na fenomenologia e tornar-se professor da Universidade de Praga, foi para a França em 1925 onde entrou em contato com Mauss, Halbwachs e LévyBruhl. De formação marxista, Gurvitch propõe que o domínio da sociologia é a realidade social onde os fenômenos sociais são pluridimensionais, dispostos em camadas em profundidade. Para ele, o problema da sociologia é entender como as totalidades sociais (os grupos, as instituições etc.) se estruturam e se modificam continuamente a partir de dois movimentos básicos: o de ruptura e o de evolução (Pereira de Queiroz, 1983:50-51).

\section{O Itinerário Brasileiro de Roger Bastide}

As décadas de 20 e 30 presenciaram no Brasil grandes transformações nos campos político, cultural e econômico. Nos anos 20, houve o surgimento das condições necessárias para as mudanças que só se efetivaram nos anos $30 \mathrm{em}$ diversas áreas. Nas palavras de Antonio Candido:

Isto ocorreu em diversos setores: instrução pública, vida artística e literária, esiudos históricos e sociais, meios de difusão cultural como o livro e o rádio (que teve desenvolvimento espetacular). Tudo ligado a uma correlação nova entre, de um lado, o intelectual e o artista; do outro, a sociedade e o Estado - devido as novas condições econômico-sociais. (Candido, 1987:182)

A reforma educacional iniciada nos anos 20 levou à criação de universidades como a Universidade de São Paulo e a Escola Livre de Sociologia e Política nos primeiros anos da década de 30. Todas as aspirações dos educadores e pensadores preocupados em construir o cidadão e a consciência nacional tiveram o solo apropriado para a sua implantação e desenvolvimento. A preocupação residiu em preparar uma nova elite que "deverá compor de homens de cultura e ciência, capazes de exercer um domínio 'natural' sobre a massa'" (Oliveira, 1979:81). ${ }^{9}$

As renovações cultural, educacional e política consistiram nos objetivos dos intelectuais nesse período, que diagnosticaram a inadequação das instituições e a necessidade urgente de realizar reformas mediante o treinamento de novas elites. Nesse contexto, a ciência, principalmente a sociologia, conforme Lúcia Lippi Oliveira, surgiu como "ca-

8 Depoimento concedido à Eliane Veras em 23/05/91.

9 A USP, em especial, foi o projeto de um grupo político paulista coordenado pela família Mesquita, que estava em franca competição com o governo federal, pois "o objetivo era dotar São Paulo de um lugar aonde seus filhos diletos pudessem estudar, e que os tornasse capazes de assumir, a longo prazo, a liderança nacional a que o estado estava destinado, graças a seus recursos econômicos e empresariais. Considerado a uma distância de meio século, este projeto parece ter alcançado uma dose considerável de sucesso" (Schwartzman, 1987:59). Vide também Limongi (1989). 
paz de orientar a ação do Estado e a ação organizadora da sociedade, mostrando-se ainda apta a despertar as forças vivas adormecidas"' (Oliveira, 1979:81-82). ${ }^{10}$

Os professores estrangeiros foram recrutados para atender a essa demanda. Motivados pelas amplas possibilidades que o Brasil representava tanto pelo início de uma carreira universitária como pelos inúmeros campos de pesquisa ainda não explorados, os professores estrangeiros vieram para a Universidade de São Paulo, para a Escola Livre de Sociologia e Política e para a Universidade do Distrito Federal (Massi, 1989:432-
433).

Roger Bastide encontrou pois um mundo intelectual em grande ebulição. A sua permanência no Brasil caracterizou-se por uma ampla participação não somente na universidade como também fora desta, escrevendo artigos e resenhas sobre os mais diversos assuntos e participando de inúmeros fóruns. Segundo seu próprio relato, percorreu um itinerário espiritual e intelectual durante o tempo em que esteve no Brasil. ${ }^{12}$ A sua trajetória foi marcada por dois movimentos básicos em seu pensamento: a crise de consciên-
cia e o encantamento.

Ocorreu nesse momento o avivamento de seu interesse por uma cultura que contiespecial com o mundo do candomblé em suas primeiras pesquisas, Bastide constatou a dificuldade em entender esta cultura tão diversa. Os estudiosos anteriores do candomblé, bem como ele no princípio, posicionavam-se de forma etnocêntrica ante o objeto de estudo. Percebeu Bastide que havia a necessidade de "converter", não no sentido de aceitar a existência do pensamento pré-lógico e negar a unidade e identidade das estruturas mentais, mas de "deixar-me penetrar por uma cultura diversa da minha. A pesquisa científica exigia de mim a passagem preliminar pelo ritual da iniciação' (Bastide, 1973:xi).

Isto o levou à adoção de uma abordagem totalmente contrária à seguida pelos outros pesquisadores, o que lhe permitiu entender o candomblé tanto pelos seus aspectos africanos como pelo seu sincretismo, possibilitando o questionamento de suas próprias

categorias lógicas enquanto pesquisador com uma mentalidade formada pelo cartesianismo.
O segundo momento derivou da descoberta, a partir desta nova atitude metodológica, ao contrário dos estudos anteriores que caracterizavam o candomblé como meras superstições, que este era um sistema de conhecimento complexo. As pesquisas de Bastide, que os chamados povos primitivos possuem um sistema de conhecimento tão complexo

10 Conforme Oliveira (1979:91), o bacharel nesse momento já não tinha o valor que era atribuído na República Velha. Os que criticavam o bacharelismo apesar de formados em direito, preferiam se apresentar como sociólogos, pois " (...) representa, entre outros aspectos, a valorização da posse de um conhecimentas, foi, por isso mesmo, saudada como louvável exemplo a se proliferar em 1933 , pelos intelectuais paulis-

11 Massi (1989) também acredita que o conhecimento a se proliferar em outros estados".

pelos historiadores ligados ao grupo dos Annales. Inclusive Lucien Febvre em ução de novos paradigmas Brasil em 1949, ressaltou a consideração e o interesse que os historiadores franceses tinham pelas peresta no quisas realizadas pela Universidade de São Paulo (Febvre, 1949).

12 Bastide inclusive esclarece o uso da expressão “ "itimerăio espiritual

va talvez uma virtude - enquanto expressão de uma "itinerário espiritual". Em seu entender esta "(...) preserbrasileiros de hoje, esses jovens que certamente não conheço, mas pelos - a ser apreciada pelos moços serem a promessa dos dias gloriosos de amanhã para seu país"' (Bastide, 1973:x). 
quanto o ocidental. Em sua avaliação, a sua grande descoberta naquele momento foi ter constatado a existência de uma metafísica no candomblé.

O encantamento que propiciou essa descoberta levou-o a uma visão original e profunda do mundo e do homem. No entender de Pereira de Queiroz (1983) houve o...

encantamento da descoberta, da penetração num universo mental, repleto de riqueza metafisica, desvendando sistemas de conhecimento subjacentes às contradições, nascimento de uma nova visäo original e profunda, não apenas do Brasil, mas do mundo e do homem em geral. (Pereira de Queiro\% 1983:14-15)

Contrapondo-se aos primeiros estudiosos do candomblé, Nina Rodrigues c Arthur Ramos, que em suas obras consideraram-no como um fenômeno marcado pela falta de raízes e com características folclóricas, Bastide possibilitou com suas análises uma reorientação das pesquisas e incentivou novos estudos.

Lm pesquisador europeu que descobriu a África no Brasil e toda sua ternura maternal e que, acima de tudo, questionou-se de sua dignidade no contato com sabedoria afrobrasileira. Um sociólogo que se conscientizou da necessidade de um novo método e de novos conceitos para a apreensão da heterogeneidade do mundo social brasileiro. Esses dois primeiros movimentos na trajetória espiritual/intelectual de Bastide no Brasil desaguaram em um terceiro momento que é o da elaboração do método. Temos, nesse sentido, a transformação espiritual/intelectual de Bastide, que de um pesquisador etnocêntrico tornou-se um pesquisador antietnocêntrico.

O seu contato com os primeiros pensadores brasileiros e suas obras produzidas até aquele período ocorreu de forma distinta. A orientação mais freqüente entre os pesquisadores estrangeiros e brasileiros desse período era a desconsideração da produção intelectual anterior por julgá-la marcada pelo autodidatismo e pelo pouco rigor analítico.

Roger Bastide, ao contrário, interessou-se em conhecer o acervo de pesquisas reali zado até então, atitude geralmente incomum entre os cientistas sociais estrangeiros. ${ }^{13}$ Esse importante acervo de pesquisas, caracterizado pelo ecletismo, na verdade possibilitou a consolidação das ciências sociais nos anos 30 conforme os novos padrões. Essa produção intelectual, assim, foi...

verdadeiro quadro de referências para os estudiosos subseqüentes, edificando uma sólida base sobre a qual podiam se elevar novas contribuiçôes do saber. Não importava que fossem obras de autodidatas: na Europa a formação especializada em ciências sociais se organizou na mesma época que no Brasil... (Pereira de Queiroz, 1989:383)

Quando os professores estrangeiros aqui chegaram, já havia um manancial de estudos preparado por longa tradição de pensadores brasileiros. Seus alunos tinham uma leitura das obras fundamentais que se baseavam em uma reflexão com ampla base empírica. Os professores estrangeiros não encontraram um País inculto, apesar de alguns assim pensarem, mas um País que já possuía um rico acervo de estudos.

Estas observações reforçam mais uma vez a necessidade de reformular as interpretações existentes sobre a produção intelectual dos primeiros pensadores nacionais, reco-

13 Pereira de Queiroz (1977) ressalta que a atitude de ignorar a produção realizada pelos autores nacionais é freqüente entre os cientistas sociais que estudam o Terceiro Mundo. 
locando a perspectiva de considerar o contexto histórico-social e econômico na análise do desenvolvimento das ciências sociais nos países periféricos bem como a comparação com o que é produzido na Europa no momento, segundo a argumentação de Pereira de Queiroz (1989).

Para esta autora, os cientistas sociais brasileiros, na angústia em escrever e reescrever a história das suas disciplinas, praticam um "etnocentrismo às avessas". Isto é, ao desprezar a produção dos primeiros pensadores nacionais, por considerá-la muitas vezes subordinada intelectualmente ao que era produzido na Europa, não percebem a riqueza e a originalidade de muitos estudos. Os pensadores brasileiros percorreram um caminho inverso ao dos cientistas sociais europeus. Dedicaram-se à investigação empírica coletando dados sobre a sociedade e a cultura brasileira. A preocupação teórica com os grandes problemas das ciências sociais, muito presente entre os pensadores europeus naquele momento, não se colocava como fundamental.

Este "etnocentrismo às avessas" necessita ser revisto, conforme observa Pereira de Queiroz:

Não percebem que estão sendo vítimas de uma forma sutil pela qual se manifestam a posição hegemônica do intelectualismo estrangeiro, por um lado, e, por outro, seu próprio complexo de inferioridade de subdesenvolvidos. Urge lembrar que, em qualquer situação de dominação, há sempre intersticios de cantinhos em que se aninham pesquisas e interpretações originais, as quais vicejam e dão frutos. (Pereira de Queiroz, 1989:386)

As ciências sociais brasileiras precisam romper com este "etnocentrismo às avessas" e valorizar não somente a contribuição dos cientistas sociais estrangeiros como também a dos pensadores brasileiros. Por isso, privilegiamos a análise de um pensador que personificou dois mundos: nascido e formado na França e, posteriormente em contato com o Brasil, considerado também brasileiro, ensinou aos jovens cientistas sociais uma atitude inovadora e criativa em diferentes níveis.

Bastide optou por analisar e incorporar várias interpretações para depois elaborar uma nova atitude metodológica em seus estudos. Ao chegar no Brasil e iniciar suas pesquisas, deparou com o predomínio das interpretações dualistas da sociedade brasileira, presentes principalmente nas obras de Gilberto Freyre e Euclides da Cunha. ${ }^{14}$

Esses autores dividiam o Brasil em dois mundos heterogêneos e subordinados. Bastide, no entanto, ao analisar o dualismo entre brancos e negros, litoral e sertão, senhores e escravos, percebeu que esses próprios grupos se subdividiam e formavam novas dualidades. A sociedade brasileira não era somente dual, mas múltipla. Assim:

Em lugar de uma única dualidade cultural branco-negro, descoberta por Nina Rodrigues, ou da dualidade cidade-sertão desvendada por Euclides da Cunha, ou da dualidade de estrato superior branco e estrato inferior negro, de que fala Gilberto Freyre, Roger Bastide descobre uma pluralidade de oposiçóes sociais e de processos diversos, imbricados uns nos outros, seu número e importância variando conforme o lugar e a época. (Pereira de Queiroz, 1977:1359)

14 Também destacamos Raimundo Nina Rodrigues, considerado por Bastide o fundador da antropologia cultural no Brasil por ter descoberto a existência do sincretismo religioso entre os santos católicos e os deuses africanos, e Manuel Querino, que inaugurou uma visão otimista acerca da integração racial brasileira, entre outros pensadores (vide Pereira de Queiroz. 1977, 1978). 
Apoiado em seu enorme conhecimento da sociologia francesa e alemã, da antropologia, da psicanálise e da história e também das importantes contribuições dos pensadores nacionais, Bastide pôde desenvolver no Brasil procedimentos metodológicos que exprimem a abordagem relativista e crítica que marcou de forma profunda a sua trajetória intelectual e espiritual. Durante as várias décadas em que esteve constantemente em atividade, Bastide produziu muito e de forma variada, refletindo sobre temas e questões de sua época e sobretudo contribuindo para o enriquecimento cada vez maior das ciências sociais. ${ }^{15} \mathrm{Na}$ próxima seção, abordaremos com maior cuidado a contribuição metodológica de Bastide, tendo em vista que tal perspectiva esclarecerá em muitos aspectos seu pensamento e seu interesse por uma grande diversidade de temas, em especial pelos estudos afro-brasileiros.

\section{O Pluralismo Metodológico de Roger Bastide}

Quando Roger Bastide iniciou sua produção intelectual ainda nos anos 20, a herança de Émile Durkheim estava presente de forma muito incisiva. Inclusive, a escolha de seus primeiros temas de estudo sobre o misticismo no campo da sociologia religiosa reflete esta orientação predominante. Ele próprio reconhece esta herança já quase no final de sua carreira acadêmica em 1971: "Pertenço à velha geração de sociólogos formada por Durkheim que acredita num determinismo, numa natureza social submetida a leis" (Bastide, 1971:29). ${ }^{16}$

Entretanto, a influência de outros pensadores foi fundamental para a redefinição de seu projeto acadêmico, ocorrida com a sua vinda para o Brasil. Aqui, ele percorreu um caminho que o levou a uma nova compreensão da sociedade brasileira e de seus problemas, bem como a uma reformulação de sua formação teórica e metodológica, momento em que a herança de Durkheim foi rediscutida e reelaborada. Roberto Cardoso de Oliveira (1988) especifica que os mais conhecidos antropólogos não se filiam a nenhum paradigma em especial, pois preferem viver a tensão enriquecedora entre eles. Acreditamos que Bastide se coloca entre os cientistas sociais que se orientam por tal procedimento.

Ao se identificar com os grupos oprimidos, em especial os negros, Bastide teve em conta, na definição de seu papel de cientista, a reabilitação da criatividade humana cole-

15 De forma sucinta, a obra de Bastide pode ser dividida em três períodos: o primeiro, que consistiu em seus primeiros anos de formação e início de sua carreira acadêmica na França (1920-1938), com a publicação de dois livros c 42 artigos. No segundo período, iniciado $\mathrm{cm} \mathrm{1938,} \mathrm{com} \mathrm{sua} \mathrm{vinda} \mathrm{ao} \mathrm{Brasil} \mathrm{e} \mathrm{encerra-}$ do com retorno definitivo à França em 1954. Publicou inúmeros artigos e 10 livros. No terceiro período (1955-1974), Bastide além de concluir e publicar sua tese Les Religions Afro-brésiliennes (1960), que se tornou sua obra mais conhecida, também divulgou 13 livros e 308 artigos.

16 Pereira de Queiroz (1983) assinala que apesar de reconhecer explicitamente a influência de Durkheim, Bastide desde o início não concordou com o mestre em relação ao predomínio do social sobre o individual. As pesquisas realizadas mais tarde no Brasil fizeram-no discordar totalmente de Durkheim nesse aspecto, conforme nos relata: "As pesquisas empíricas efetuadas por Roger Bastide no Brasil levaramno a se contrapor cada ve $z$ mais àquele que considerava, no entanto, como influindo basicamente em seu pensamento sociológico. Flas the mostravam a importância do individuo como elemento modificador, em todos os procedimentos e processos sociais; a presença da ordem como a característica mais marcante das coletividades, para presidir diretamente à operação das representações coletivas; a necessidade de desvendar os mais sutis julgamentos de valor negativos, referentes às maneiras de ser e de agir de sociedades que não as ocidentais" (Pereira de Queiroz, 1983:54). 
tiva e individual, identificação esta possível de ser detectada devido a sua origem protestante em uma França essencialmente católica. Beylier (1977) assinala com precisão que nas ciências sociais é decisiva a formação, a educação e a personalidade do pesquisador em sua relação com o objeto. Na análise da obra brasileira de Roger Bastide, seu objeto principal, afirma que:

acreditamos que existe na pesquisa de Roger Bastide no Brasil, e conseqüientemente em sua obra, uma apreensão da realidade que é original, e que pode ser compreendida, apenas porque trata-se dele próprio, de sua formação e educação. Mas é necessário acrescentar que sua 'praxis' é também um reflexo da realidade que ele encontrou no Brasil. (Beylier, 1977:36) ${ }^{17}$

No caso de Roger Bastide, os anos de formação ocorridos principalmente na França explicam muitas de suas características de pensador e pesquisador plural e essencialmente humanista. $O$ fato de ter nascido numa região da França marcada por conflitos religiosos e pertencer a uma minoria protestante definiram muitos dos aspectos essenciais de sua personalidade, como o inconformismo e a identificação imediata com as minorias.

Roger Bastide também se transformou em um francês bem-educado que incorporou de seus professores de filosofia e sociologia o espírito crítico, o rigor acentuado e um grande interesse pelo desvendamento dos fenômenos sociais e humanos.

Entretanto, o fato também de pertencer a uma região meridional da França o levou a desenvolver uma grande sensibilidade às artes, principalmente à poesia, interesse que o marcou profundamente e o deixou...

sempre mais sensivel às belezas da poesia e do imaginário do que às grandes promessas das descobertas cientificas. Ele teria com certeza, de bom grado, subscrito as palavras de uma certa rainha provençal: 'A poesia aquela ciência, a mais exata de todas as ciências'. Convencido de que existe na realidade social uma verdade que apenas uma alma de poeta pode descobrir, ele não procurará reduzir a vida das sociedades às aparências e ao manifesto. O 'mar interior', carrefour de povos, de raças $e$ de civilizações, abrindo-lhe as portas através da poesia. ao além-mundo, o introduzia também ao mundo do outro. Muito além das aparências visiveis, ele se mostrará sensivel às alterações nas quais se enraizam as diferenças, as oposições que geram o espirito dos povos. (Beylier, 1977:39-40)

E, para isso, usou procedimentos variados como a observação participante, a observação controlada e a intuição poética, conforme lembra Pereira de Queiroz (1983). A intuição sendo entendida como o esforço de simpatia estabelecido entre o pesquisador e seu objeto, levando-o a ultrapassar os limites superficiais, a observação participante consistindo na vivência de seu objeto, a adesão ao fato analisado e a observação controlada, a vigilância epistemológica necessária ao tratamento do seu objeto (Pereira de Queiroz, 1983).

Beylier (1977), que fez uma análise extremamente criteriosa dos procedimentos metodológicos na obra de Bastide, chama a atenção para o fato de que a relação entre o

17 Charles Beylier elaborou a sua tese de doutorado sobre Bastide nos anos 70 e esta até o momento não foi traduzida para o português. Todas as citações da tese de Beylicr presentes neste artigo foram traduridas por Luci Viegas Cardoso. 
cientista social e o seu objeto, defendida por Bastide, não corresponde à seguida pela Escola Francesa de Sociologia. Ao contrário, para ele os fatos sociais necessitam ser entendidos a partir da atividade humana e dos interesses que os motivam. Por isso, o cientista social deve utilizar a observação participante, a observação controlada e a intuição poética como formas de aproximação da realidade social. O dom da empatia deve ser aliado à sensibilidade poética como forma de aproximar o pesquisador o máximo possível de seu objeto. Segundo Beylier, a problemática da relação entre o sujeito e o objeto nas ciências sociais para Bastide tinha que ser encarada de outra forma:

Ao invés de se interrogar para saber como é possivel se chegar a uma objetividade perfeita, nunca alcançada, ou à descoberta da verdade em si mesma, nunca dominada, seria melhor, acredita ele, mudar os termos: sendo dado que a única observação que permite descobrirmos o real social é a 'observação participante', reconheçamos que a sabedoria do homem está limitada ao campo que ele ocupa no espaço e no tempo, no seu lugar em uma certa estrutura e procuraremos descobrir como utilizar da melhor forma possivel este condicionamento para chegar a um conhecimento o mais científico possivel. (Beylier, 1977:214)

O sociólogo, portanto, tem que estar a par dos motivos de suas escolhas, de suas preferências por tais objetos e dos valores presentes em suas análises. Para Bastide, a psicanálise auxilia na descoberta dos condicionamentos sociais que estão presentes nos pesquisadores. Nesse sentido, o conhecimento do método psicanalítico é fundamental para o uso adequado da observação controlada. A psicanálise assume para Bastide uma grande importância. Cabe esclarecer que o interesse de Bastide pela psicanálise aparece desde os anos 30. Em 1940, ele ofereceu um curso na Faculdade de Filosofia, Ciências e Letras, ocasião em que procurou sistematizar suas preocupações sobre tal tema ao traçar um quadro geral das relações entre a sociologia e a psicanálise. Bastide entende que a psicanálise tem condições de oferecer uma contribuição nova e original à sociologia ${ }^{18}$

Somente assim o sociólogo terá condições para se auto-analisar e romper com o senso comum tanto vulgar como científico, pois na construção do objeto é preciso, como Bourdieu diria mais tarde,

romper com o senso comum, quer dizer, com representações partilhadas por todos, quer se trate dos simples lugares-comuns da existência vulgar, quer se trate das representações oficiais, freqüentemente inscritas nas instituições, logo, na objectividade das organizações e nos cérebros. (Bourdieu, 1989:34)

Para nós, Bastide pode ser definido como um pesquisador que antecipou questionamentos sobre a prática sociológica que só décadas mais tarde seriam discutidos com maior cuidado. Ou melhor, tratou de questões que a sociologia, então essencialmente positivista, ainda não conseguia enxergar. O uso da intuição poética pelo pesquisador é um exemplo relevante desses novos procedimentos ainda nem assinalados pelas ciências sociais naquele período. Em um pequeno texto publicado em 1946, Bastide, de forma muito criativa, discute esta questão com um crítico imaginário. Para ele, apesar de ser acusado de uma tendência grave na ótica positivista que é uso da poesia como método

18 Somente em 1948 foi publicado o livro Sociologia e Psicanálise, fruto desse curso ministrado na USP (Bastide, 1948). 
sociológico, a poesia e a literatura têm muito a oferecer aos sociólogos, pois "propõem métodos de trabalho, habituam-nos a certas maneiras em geral por nós pouco utilizadas para penetrar o social"' (Bastide, 1983:81).

Segundo a sociologia positivista, o poeta não ultrapassa as aparências dos objetos, pois apenas apreende a superfície dos fenômenos ou coisas. Bastide, ao contrário, ressalta que o próprio Durkheim afirmou que a simples reunião de homens pensantes possibilita o aparecimento de fenômenos novos e originais. O sociólogo não deve apenas adequar os fenômenos em determinados quadros, mas mergulhar no seu objeto através da intuição poética. É preciso aproximar-se do seu objeto, não se transformando nele pois isto não é possível, mas "apelando para um ato de amor transcender nossa personalidade para aderir à alma que está ligada ao fato a ser estudado"' (Bastide, 1983:84).

A complexidade social exige o uso de métodos variados, entre estes o método poético. Bastide denomina esse procedimento de princípio dos projetores convergentes no qual o objeto é analisado a partir de diferentes faces. Se a sociologia pretende apenas conhecer o racional na sociedade, ela será uma ciência parcial. A sociologia, para ser uma ciência total, deve utilizar também a intuição poética que possibilita conhecer os elementos irracionais, o imaginário e o inconsciente coletivo.

O sociólogo pode utilizar a expressão poética no sentido de uma poesia sociológica que tem o objetivo de oferecer a imagem mais exata da sociedade. Nas palavras de Bastide:

Trata-se pois de uma expressão poética especial - a expressão da poesia sociológica.(...) A expressão poética é uma forma de exatidão científica. Ela só intervém quando a detém uma seriação conceitual, ela não deve intervir onde não tenha o que fazer. A sociologia é exatamente aquele edificio de relações racionais do qual o senhor falava, [o crítico imaginário], um conjunto de conceitos e de leis, de pesquisas causais e de definições objetivas. Mas uma linha melódica deve cercar esse conjunto para dar a impressão do que existe em toda a sociedade de vida, de harmonia, ou mesmo de notas falsas, enfim. de vida criadora, de sua organização em movimento, de seu equilíbrio no decorrer dos tempos (...) É essa poesia tão diferente - a poesia sociológica - que eu tentava traduzir. Neste caso a poesia não é traição, mas a vontade de alcançar uma fidelidade mais precisa. (Bastide, 1983:86-87)

Isto fica bastante transparente em suas análises da poesia e literatura negras, conforme visto no momento anterior deste artigo. Bastide, em nosso entender, antecipou reflexões críticas sobre o paradigma positivista e a sua viabilidade para o estudo do mundo social. Já nos anos 40, Bastide construiu posicionamentos teóricos e metodológicos que caminharam no sentido de buscar um modelo de compreensão e de intervenção na realidade a partir de diferentes instrumentos existentes nas ciências sociais, na história, na psicanálise, na arte e na poesia.

\section{CONSIDERAÇÕES FINAIS}

Precursor nos campos teórico e metodológico, Bastide, sem qualquer preconceito, utilizou procedimentos pouco usuais desde que estes possibilitassem um entendimento mais exato do fenômeno estudado. Interessou-se por temas pouco aceitos nas ciências sociais naquele período, como os fenômenos estéticos. Antecipou reflexões sobre a prática do cientista social, como a vigilância epistemológica, e defendeu a aproximação com a psicanálise. Dialogou com diferentes campos do conhecimento sem a menor restrição. 
Bastide propôs uma concepção de ciência mais global que não se restringe somente ao conhecimento racional. De certa forma, sua concepção se aproxima daquela que bem mais tarde Robert Nisbet (1979) formulou sobre a sociologia. Segundo Nisbet, a sociologia é ao mesmo tempo uma ciência e uma arte, pois se alimenta das mesmas fontes de imaginação criadora presentes na poesia, na música, na pintura e no teatro. Tanto os sociólogos como os artistas preocupam-se em traduzir a universalidade e a individualidade da experiência humana através da elaboração de paisagens e retratos.

É claro que a arte e a ciência têm as suas próprias identidades e meios de expressão. No entanto, o cientista e o artista procuram conhecer a realidade, iluminar e interpretar o desconhecido. Os jovens cientistas precisam superar a visão restrita sobre a construção metodológica e teórica das ciências propiciada pela burocratização intelectual. Tal concepção já se encontrava presente na obra de Bastide nos anos 30 e 40 .

Fomentador de uma visão plural do Brasil, Bastide, em seus estudos sobre a situação racial brasileira, não se ateve ao manifesto que geralmente procura mostrar a existência de uma suposta democracia racial. Ao contrário, procurou na fronteira entre o consciente e o inconsciente as concretas manifestações do preconceito racial. Tanto na análise das manifestações literárias como do material empírico coletado no Projeto UNESCO/ANHEMBI, constatou a presença inequívoca da discriminação e do preconceito racial no Brasil.

Relembrando suas considerações sobre Machado de Assis e sua aproximação com esse escritor, percebemos a identificação imediata de Bastide com obra machadiana, em especial com a representação que esta traz do novo modo de vida brasileiro, essencialmente urbano. O nativismo de Machado de Assis sustenta-se na mistura das raças e na nova estruturação da sociedade brasileira, não se apegando somente ao exotismo de suas paisagens.

Com olhos brasileiros Bastide percebeu não somente o manifesto dos fenômenos, mas a essência da cultura brasileira. Com a humildade que todos os grandes pensadores necessitam possuir, afirmou que o homem não é um Deus que tudo pode, mas um "questionador" que precisa compreender a resposta dos fatos. Bastide, assim como Machado de Assis, foi também um dos maiores paisagistas do Brasil.

\section{REFERÊNCIAS BIBLIOGRÁFICAS}

BASTIDE, R., 1939. Gaston Richard. Revista Sociologia, 1:92-95.

BASTIDE, R., 1940. Machado de Assis, paisagista. Revista do Brasil, 3.

BASTIDE, R., 1943. A Poesia Afro-Brasileira. São Paulo: Martins.

BASTIDE, R., 1948. Sociologia e Psicanálise. São Paulo: Instituto Progresso Editorial.

BASTIDE, R., 1971. As Religiões Africanas no Brasil. 2 vol. São Paulo: Pioneira.

BASTIDE, R., 1973. Estudos Afro-brasileiros. São Paulo: Perspectiva.

BASTIDE, R., 1983. 1) A propósito da poesia como método sociológico. Primeira conversa com o crítico. 2) A propósito da poesia como método sociológico. Segunda conversa com o crítico. In: Roger Bastide (M. I. Pereira de Queiroz, org.), pp. 81-87. São Paulo: Ática.

BASTIDE, R. \& FERNANDES, F., 1955. Relações Raciais entre Negros e Brancos em São Paulo. São Paulo: Anhembi. 
BEYLIER; C., 1977. L'oeuvre Brésilienne de Roger Bastide. Thèse de Doctorat de 3o Cycle, 2 vols. Paris: Ecole de Hautes Etudes en Sciences Sociales.

BRAGA, M. L. S., 1994. A Sociologia Pluralista de Roger Bastide: um Itinerário. Dissertação de Mestrado, Brasília: Universidade de Brasília.

BOURDIEU, P., 1989. O Poder Simbólico. Rio de Janeiro: Editora Bertrand do Brasil.

CANDIDO, A., 1987. A Educação pela Noite e Outros Ensaios. São Paulo: Ática.

DUARTE, P., 1955. Prefácio. In: Relações Raciais entre Negros e Brancos em São Paulo (R. Bastide \& F. Fernandes, orgs.). São Paulo: Anhembi.

FEBVRE, L., 1949. O homem do século XVI. O Estado de São Paulo, 3 de setembro de 1949.

HEILBRON, J. 1985. Les métamorphoses du durkheimisme, 1920-1940. Revue Française de Sociologie, 26(2):206-230.

LIMONGI, F. 1989. Mentores e clientelas da universidade de São Paulo. In: História das Ciências Sociais no Brasil (S. Miceli, org.), pp. 217-233. São Paulo: Vértice: Editora Revista dos Tribunais: Idesp.

MASSI, F. P., 1989. Franceses e norte-americanos nas ciências sociais brasileiras 1930-1960. In: História das Ciências Sociais no Brasil (S. Miceli, org.), pp. 410-456. Vol.1. São Paulo: Vértice: Editora Revista dos Tribunais: Idesp

NISBET, R., 1979. La Sociologia como Forma de Arte. Madrid: Espasa - Calpe S.A.

OLIVEIRA, L. L., 1979. Elite intelectual e debate político nos anos 30. Dados, 22:75-93.

OLIVEIRA, R. C., 1988. Sobre o Pensamento Antropológico. Rio de Janeiro: Tempo Brasileiro/Brasília: CNPq.

PEREIRA DE QUEIROZ, M. I., 1977. A sociologia brasileira na década de 40 e a contribuição de Roger Bastide. Ciência e Cultura, 29(12):1353-1361.

PEREIRA DE QUEIROZ, M. I., 1978. Uma nova interpretação do Brasil: A contribuição de Roger Bastide à sociologia brasileira. Revista do Instituto de Estudos Brasileiros, pp. 101-121.

PEREIRA DE QUEIROZ, M. I., 1983. Roger Bastide. São Paulo: Ática.

PEREIRA DE QUEIROZ, M. I., 1989. Desenvolvimento das ciências sociais na América Latina e contribuição européia: o caso brasileiro. Ciência e Cultura, 41(4):378-388.

RICHARD, G., 1912. La Sociologie Générale et les Lois Sociologiques. Paris: Octave Doin et Fils, Editeurs.

SCHWARTZMAN, S., 1987. A força do novo: por uma sociologia dos conhecimentos modernos no Brasil, Revista Brasileira de Ciências Sociais, 2:47-66.

\section{DEPOIMENTOS}

Depoimento à Eliane Veras:

Florestan Fernandes, Brasília, 23 de maio de 1991.

Depoimento à autora:

Antonio Candido, São Paulo, 26 de maio de 1994. 


\section{A QUESTÃO RACIAL NO PENSAMENTO DE GUERREIRO RAMOS \\ Marcos Chor Maio}

\section{INTRODUÇÃO}

O objetivo deste trabalho é abordar o tema das relações raciais na obra de Guerreiro Ramos tendo como pressuposto que esta questão encontra-se intimamente vinculada a determinados aspectos da trajetória social e intelectual do sociólogo. Sugiro que a militância no movimento negro e a participação na burocracia estatal foram postos privilegiados a partir dos quais Guerreiro promoveu uma releitura do pensamento social brasileiro, identificando-se com uma matriz de pensamento que alguns estudos têm caracterizado como iberismo (Vianna, 1991, 1994; Lima, 1994; Morse, 1988). O tema do negro aparece então associado a um ideal comunitário e integracionista.

Baiano, mulato e oriundo das classes subalternas: eis a origem de Guerreiro Ramos. ${ }^{1}$ Nascido em Santo Amaro da Purificação, cidade próxima a Salvador, Guerreiro fez o curso secundário no Ginásio da Bahia, tradicional instituição freqüentada pelas elites baianas e localizado na capital do estado. Na juventude participou do ambiente cultural da classe média baiana, escreveu no jornal diário $O$ Imparcial e publicou dois livros: O Drama de Ser Dois e Introdução à Cultura. Foi militante do movimento integralista e, em seguida, do Centro de Cultura Católico. Além dos contatos com Rômulo de Almeida, Afrânio Coutinho e José Valadares, jovens intelectuais à época, Guerreiro trabalhou para Isaías Alves, político e intelectual de grande influência na área da educação, futuro secretário de Educação do Estado da Bahia, criador da Faculdade de Filosofia da Bahia e irmão do Interventor no estado, Landulfo Alves.

Em 1939, Guerreiro Ramos migrou para o Rio de Janeiro com uma bolsa de estudo do Governo do Estado da Bahia para cursar ciências sociais. Pertenceu à primeira turma da recém-criada Faculdade Nacional de Filosofia (1939) da Universidade do Brasil. Em 1942, ao finalizar o curso de ciências sociais, o sociólogo baiano, segundo sua própria versão, foi preterido tanto na cadeira de sociologia como na de ciência política. O passado integralista teria sido um forte instrumento de pressão de seus desafetos para impedir a continuidade de sua carreira acadêmica num período em que o Brasil declarava sua entrada na guerra ao lado das Forças Aliadas. Da universidade à burocracia estatal: esta foi a solução. Por indicação do então diretor da Faculdade Nacional de Filosofia (FNFi), San Tiago Dantas, Guerreiro ministrou aulas no curso "Problemas Econômicos e Sociais do Brasil", no Departamento Nacional da Criança, e logo depois tornou-se funcionário do Departamento de Administração do Serviço Público (DASP). 
No final dos anos 40 engaja-se no movimento negro por meio do Teatro Experimental do Negro. No começo dos anos 50, com a volta de Getúlio Vargas ao poder, Guerreiro, como funcionário do DASP, é convidado a trabalhar na assessoria econômica do gabinete civil da presidência, junto com Rômulo de Almeida, Jesus Soares Pereira e Inácio Rangel. Ao analisar este período, Guerreiro afirma que a atuação no Governo Vargas foi de suma importância para a sua compreensão do Brasil (Oliveira, 1995a). Por essa ocasião torna-se membro do Instituto Brasileiro de Economia, Sociologia e Política (IBESP), futuro Instituto Superior de Estudos Brasileiros (ISEB).

\section{REFLEXÕES INICIAIS SOBRE OS INTERCURSOS ÉTNICOS}

As primeiras incursões de Guerreiro Ramos pelo campo das relações raciais no Brasil estiveram sob a influência da sociologia americana, especialmente aquela difundida pelo sociólogo Donald Pierson. Em cursos e trabalhos no DASP, o sociólogo pensou a questão racial por meio de Robert Park. W. I. Thomas, Florian Zanieck e Emory Borgardus. É nesta fase de identificação com a "Escola Sociológica de Chicago" que Guerreiro considera que o preconceito étnico no Brasil seria de natureza mais econômica e cultural do que racial (Azevedo, 1955). Concomitantemente o sociólogo revela interesse pelos temas da "assimilação" e da "aculturação", além de valorizar o processo de institucionalização das ciências sociais a partir da década de 30, especialmente em São Paulo (Ramos, 1948; Ramos \& Garcia, 1949). Neste sentido, Guerreiro afirma que Donald Pierson...

trouxe para o Brasil o estilo das universidades americanas, especialmente o da Universidade de Chicago, onde se doutorou. A atuação deste scholar americano deve ser ressaltada como das mais eficientes, pois, graças a ela, se tem criado em São Paulo uma equipe de jovens treinados em pesquisa sociológica, que estão sendo aproveitados em estabelecimentos oficiais e particulares e contribuindo para a criação, naquele estado e no País, de um ambiente tecnicamente exigente e adverso a improvisações (...) Seu estudo publicado em português com o título de Brancos e Pretos na Bahia, sobre ser uma análise lúcida e clara das relações de raça naquele estado, revelounos a riqueza da metodologia sociológica americana. (Ramos \& Garcia, 1949:9-16)

A aproximação de Guerreiro Ramos da sociologia americana deve-se também à própria inserção do sociólogo em uma instituição criada nos primórdios do Estado Novo com o intuito de modernizar o aparato estatal. Para tanto, o DASP necessitava de um novo tipo de técnico, munido de conhecimentos racionais e científicos. Guerreiro Ramos esteve profundamente enfronhado nos problemas de administração e sempre por meio de uma ótica política (Soares, 1995). No entanto, viveu constantemente a tensão entre o seu lado acadêmico e a sua condição de funcionário (Oliveira, 1995a). Poucos anos adiante, em 1952, o sociólogo tornou-se professor da Escola Brasileira de Administração Pública (EBAP) da Fundação Getúlio Vargas.

Entretanto, é importante ressaltar que a apreciação de Guerreiro Ramos sobre as ciências sociais no Brasil sofrerá uma solução de continuidade com o seu engajamento político no Teatro Experimental do Negro (TEN). Instituição criada em 1944, no fim do regime autoritário estadonovista, sob a liderança de Abdias Nascimento, o TEN procurou resgatar em um novo patamar a luta política dos negros da década de 30 , cuja refe- 
rência mais importante era a Frente Negra Brasileira (1931-1937). A princípio, o TEN constituiu-se como movimento cultural, politizando-se em seguida com a democratização do pós-Segunda Guerra Mundial, a luta contra o racismo em escala mundial e a eclosão dos movimentos africanos de libertação nacional. Foi esta instituição que patrocinou as Convenções Nacionais do Negro em 1945 (São Paulo) e 1946 (Rio de Janeiro), a Conferência Nacional do Negro (1949) e o I Congresso do Negro Brasileiro (1950), os dois últimos eventos realizados também no Rio de Janeiro (Nascimento, 1982).

Ideologicamente o TEN viveu durante os anos 40 e 50 uma situação ambígua. Em vários momentos, sua liderança política e intelectual oscilou entre o reconhecimento dos legítimos direitos dos negros à cidadania plena e o diagnóstico da incapacidade temporária dos mesmos ao exercício da política por terem uma mentalidade pré-lógica, pré-letrada. ${ }^{2}$ Ademais, o TEN acreditava que os negros deveriam seguir os caminhos trilhados pelas classes médias e dominantes no Brasil. Portanto, o TEN viveu o dilema entre a afirmação política da identidade negra e a influência do etnocentrismo europeu adaptado à realidade brasileira, ou seja, a "ideologia do branqueamento" (Mauês, 1988).

Alberto Guerreiro Ramos conheceu Abdias Nascimento em 1939. Estes dois intelectuais não brancos tinham alguns aspectos em comum: participaram da Ação Integralista Brasileira e sofreram forte influência da religião católica (Nascimento \& Nascimento, 1991; Oliveira, 1995a). Guerreiro só se engajou no movimento negro em sua fase áurea, na virada da década de 40 para 50 (Costa Pinto, 1953), quando a associação procurou ampliar seu raio de ação. Inicialmente Guerreiro demonstrou desconfiança, motivada pela natureza do movimento, de expressão racial e reivindicatório. Ao mesmo tempo, havia uma preocupação com a sua própria inserção social, um mulato "pegado de mau jeito pela sorte (...) com a vida por organizar"' (Ramos, 1950:35-36). Guerreiro só veio a participar do TEN quando já havia se estabelecido profissionalmente e começava a obter reconhecimento social. Neste sentido, seu engajamento se traduziu em maior visibilidade para um mulato em processo de ascensão social.

Em 1949, Guerreiro assume a direção do recém-criado Instituto Nacional do Negro, órgão do TEN que estaria voltado para a pesquisa sociológica. O Instituto tinha o intuito de ampliar as atividades do movimento negro, reforçando os aspectos pedagógicos e culturais (Nascimento, 1950):

Em maio desse mesmo ano, o sociólogo do DASP participou da Conferência Nacional do Negro, na qual foi eleito para o comitê organizador, junto com Abdias Nascimento e Édison Carneiro, do Primeiro Congresso Negro Brasileiro, que seria realizado em agosto de 1950 .

O intelectual baiano inicia sua militância considerando que o "problema do negro" deveria ser visto a partir das diferenças regionais, de classe e da divisão rural/urbano. Ademais, aponta a existência de uma "psicologia diferencial do negro brasileiro", advinda de um "forte ressentimento" do negro das "classes inferiores" com relação aos

Mauês (1988) lembra que as lideranças negras à época estariam influenciadas pelo pensamento antropológico de Tylor e Frazier, além das idéias filosóficas de Lévy-Bruhl. As elites intelectuais negras viriam a condição do negro nos seguintes termos: afirmação dos limites do negro em pensar abstratamente acrescido da idéia de que suas tradições e crenças estariam no limiar da ingenuidade e do primitivismo, reforçando assim as qualidades da emotividade, passionalidade e a teatralidade inerente aos negros. 
negros "de elevada categoria social", que o leva a acreditar que pelo emprego de "métodos da sociologia psicodinâmica" este fenômeno poderia ser melhor compreendido. Em sua perspectiva, o preconceito em relação ao negro seria de cor e não de raça e que não haveria uma linha de casta no Brasil. Por fim, Guerreiro critica a valorização das "sobrevivências africanas" por parte de sociólogos e antropólogos, considerando que os negros estariam mais preocupados em ascender socioculturalmente (Ramos, 1948).

O sociólogo considerava que o melhor caminho para os negros atingirem o padrão de comportamento das elites dominantes seria "transformar a luta de classe num processo de cooperação, [...] num fator de equilíbrio e de compreensão social [...]" (Ramos, 1950c:23-24). A proposta do TEN lembraria, em muito, "o famoso Grupo de Oxford com seus intentos de renascença religiosa e o grupo francês de L'Ordre Nouveau, inspirado pelo saudoso filósofo Arnaud Dardieu e também orientado para a reconstrução social através da pessoa humana'" (Ramos, 1950c:23-24).

Ascensão social por meio de um processo cooperativo e grupoterápico que resgatasse a pessoa humana. O projeto de Guerreiro lembra em muito a visão do ex-militante católico do final dos anos 30 quando escreveu Introdução a Cultura (Ramos, 1939).

Este livro oferece uma proposta conservadora de resgate da pessoa, crença muito comum nas hostes católicas e integralistas nesse período, em detrimento da versão liberal de indivíduo. O olhar para o medievo, holístico e hierarquizado indica também a influência da idéia de restauração. ${ }^{3}$ Conforme Oliveira:

trata-se de uma proposta de transformação que pode ser compreeendida pela abordagem de alguns pares de conceitos: cultura versus civilização; pessoa versus individuo; orgânico versus mecânico; sentimento trágico de vida versus sentimento burguês da existência; sofrimento versus ressentimento. (Oliveira, 1995a:30)

Neste sentido, o teatro era um instrumento de valorização, de integração dos negros à nacionalidade (Nascimento, 1950), diante das marcas ainda presentes do passado escravocrata, associadas aos efeitos perversos da modernização capitalista. $O$ uso do psicodrama e do sociodrama são indicadores precisos da secularização do catolicismo de Guerreiro nos anos 50, inspirado agora no sociólogo e psicoterapeuta judeu austríaco, radicado nos E.U.A., Jacob L. Moreno. A psicologia social tão em voga no pós-guerra, diante do esforço de tornar inteligível o genocídio nazista, deveria ser a marca de distinção do movimento negro. Afinal,

o TEN não é orientado truculenta e agressivamente contra o preconceito de côr. Ao contrário, proclama, pela palavra de seu criador [Abdias Nascimento], não ser esta a tática acertada a ser usada em 'nossa' questão racial, tão diferente da norte-americana. Ele é um campo de polarização psicológica, onde o homem encontra oportunidade de eliminar as suas tensões e os seus recalques. (Ramos, 1950c:24)

É interessante observar que Guerreiro, não destoando da preocupação de outros sociólogos que estudaram as relações raciais no Brasil, está atento ao padrão dos intercursos étnicos estabelecido nos Estados Unidos e faz questão de registrar a diferença entre as experiências americana e brasileira. dade (1979). 
Como já mencionado, em 1949 Guerreiro tornou-se diretor do Instituto Nacional do Negro, órgão do TEN que estaria voltado para a pesquisa sociológica. Nesta fase aprofunda sua análise do enfoque político-ideológico do TEN afinado com a visão integracionista de Abdias Nascimento. Este seria o melhor caminho para os negros ascenderem socialmente até atingirem o comportamento da classe média e superior. Para a realização desse projeto, não destituído de ambigüidades, a solução preconizada por Guerreiro seria a formação de uma "elite negra'. Qual seria o papel dessa elite?

O TEN, segundo Guerreiro, deveria se transformar em uma elite política e intelectual negra que tivesse por missão superar o descompasso existente entre a simbólica condição de cidadão livre adquirida pelo negro após a abolição e sua adversa situação econômica e sociocultural, ainda presente sessenta anos depois. A solução seria uma pedagogia da cidadania que, além de socializar os negros nas novas condições geradas após a Abolição, alterasse a estrutura de dominação da sociedade brasileira (Ramos, 1953a).

Assim, o TEN formaria uma intelligentsia com o objetivo de "ganhar a confiança dos poderosos desta terra. Que eles reconheçam em nosso movimento uma expressão de elite, um princípio de equilíbrio e de harmonia social'" (Ramos, 1950d:50).

É interessante observar que o conceito de intelligentsia utilizado por Guerreiro para representar um determinado segmento da sociedade, apesar de inspirar-se originalmente na idéia de um grupo de intelectuais "que produz e difunde idéias que contribuam para a reforma social ou para o processo revolucionário" (Oliveira, 1995a:53), é apropriado em um sentido muito especial, ou seja, a de um "intérprete em geral da sociedade" (Vianna, 1994:379). Por isso mesmo Guerreiro recusa qualquer solução do tipo "partido de negros", na medida que "o homem de côr, entendido como homem-massa, não estaria habilitado às funções de mando, as quais, como é sabido, supõe uma longa aprendizagem" (Ramos, 1950:38). Caberia a intelligentsia negra a elevação social e sem conflitos da "massa negra".

Desse modo, a agenda política de Guerreiro era composta pelos seguintes tópicos: afirmação da singularidade dos negros com a eliminação dos recalques advindos do passado, ascensão social e econômica, constituição de uma intelligentsia, ou seja, de "uma espiritualidade e uma missão" (Ramos, 1950d:50). Só assim haveria a redução da enorme distância entre o "negro legal" e o "negro real". Este programa foi sintetizado por Guerreiro em sua interpretação do "mito da negritude" em consonância com o movimento negro das ex-colônias francesas na África (Sartre, 1965).

$\mathrm{Na}$ visão do sociólogo, o Brasil deveria liderar a política de democracia racial em escala mundial pois seria o único país a oferecer, em matéria de relações raciais, uma solução adequada. Os negros no Brasil gozariam formalmente dos mesmos direitos políticos que os brancos, embora esses direitos não fossem exercidos em sua plenitude devido à desigualdade na distribuição de bens econômicos e culturais. Desse modo, o TEN assumiria a vanguarda desse movimento por meio do "mito da negritude", mito este que se traduziria por uma subjetividade,

um elemento passional que se acha inserido nas categorias clássicas da sociedade brasileira. (...) Humana, demasiadamente humana, é a cultura brasileira, por isto que, sem desintegrar-se, absorve as idiossincrasias espirituais, as mais variadas. E até compõe com elas a sua vocação ecumênica à sua indole compreensiva e tolerante. A cultura brasileira é, assim, essencialmente católica, no sentido que nada do que $e ́$ humano lhe é estranho. (Ramos, 1950b:11) 
Portanto, o "mito da negritude" no Brasil seria uma versão atualizada, elaborada pela intelligentsia negra, do legado da cultura democrático-racial brasileira sob a égide de um catolicismo adocicado, à Gilberto Freyre. Caberia a essa intelligentsia negra junto com as elites brancas articular esse processo democratizante.

Coerente com essa nova visão, Guerreiro apresenta no final do ano de 1950 sua crítica aos trabalhos acadêmicos até então elaborados sobre o negro. $O$ autor considerava que esses estudos estariam defasados e envoltos pelo academicismo. Assim, as investigações de natureza histórica, folclórica ou antropológica, apesar de seu valor documental, partiriam do princípio de que o problema do negro veio a ser resolvido com a abolição e que caberia apenas pesquisar as "sobrevivências africanas" como se fossem "peças de museu", em vez de elevar os negros à condição de "forças operativas".

Considerando a insistência na preservação da tradição religiosa africana como um indicador de atraso, de inadequação aos desafios do desenvolvimento capitalista no Brasil, Guerreiro propõe mecanismos assimilativos, que favorecessem a ascensão social, econômica e cultural da população negra. Esta assimilação, católica ou protestante, ao espírito capitalista aproximaria brancos e negros, o que exigiria também uma "reeducação das camadas brancas e brancóides"' (Ramos, 1950a:2). Neste cenário, já não haveria espaço somente para a afirmação de uma questão racial: revelava-se a premência da construção de uma verdadeira identidade nacional. Para tanto seria necessário remover o racismo dos setores dominantes da sociedade, em sua expressiva maioria, brancos.

Se há determinadas noções que contribuiriam para o fortalecimento de certos estigmas sobre o negro (mentalidade pré-lógica, pré-letrada, crítica à influência das religiões africanas sobre os negros), é importante ter em vista que Guerreiro mantém seus preconceitos em constante tensão com a proposta de formação de uma intelligentsia negra, preocupada em superar as adversidades sofridas pelos negros.

A partir dos primórdios da década de 50 as críticas ao pensamento social brasileiro, a disputa político-acadêmica no interior do campo das ciências sociais e a busca de alternativas políticas, tendo como referência central a atuação dos intelectuais, tornam-se os eixos fundamentais do trabalho sociológico de Guerreiro. Esta fase se inicia com a sua participação no Governo Vargas e se desenvolve na formação do IBESP. Pelo menos até 1955, as reflexões de Guerreiro sobre a intelectualidade brasileira não prescindirão da análise sobre o negro, só que cada vez mais próxima, até se confundir com a questão nacional.

\section{O DEBATE NOS ANOS 50}

No início dos anos 50 Guerreiro Ramos trabalhou na Casa Civil do Governo Getúlio Vargas (Oliveira, 1995a). Em 1953 Guerreiro começa a participar de reuniões com um grupo de intelectuais (Hélio Jaguaribe, Ignácio Rangel, Roland Corbisier, Juvenal Osório Gomes, Hermes Lima e outros) que criaram posteriormente o Instituto Brasileiro de Estudos Sociais e Políticos (IBESP), futuro ISEB. Fazia parte da pauta de discussões do IBESP, segundo Schwartzman,

(...) o subdesenvolvimento brasileiro, a busca de uma posição internacional de não alinhamento e de 'terceira força', um nacionalismo em relação aos recursos naturais do País, uma racionalização maior da gestão pública [e uma] maior participação de setores populares na vida politica. (Schwartzman, 1981:3) 
No início de seu envolvimento com o IBESP, Guerreiro Ramos escreveu O Processo da Sociologia no Brasil (1953), trabalho que reflete a nova fase de sua atuação intelectual e política. Logo na introdução, o autor afirma que "assumi[u] diante das obras dos sociólogos brasileiros uma atitude de naturalista [...]' (Ramos, 1953:5), num esforço de construção de sua identidade nos embates no campo acadêmico.

Partindo do princípio de que a sociologia deveria ser "um instrumento de construção nacional" (Ramos, 1953:9), Guerreiro traça uma linha divisória entre as correntes sociológicas que informariam o mundo intelectual brasileiro. A primeira delas, a "autenticamente nacional", preocupada com a singularidade brasileira e dotada de um caráter funcional seria representada por Silvio Romero, Euclides da Cunha, Alberto Torres e Oliveira Viana. A segunda tendência, denominada "'heteronômica", "consular", "enlatada", seria uma "glosa das orientações doutrinárias vigentes nos centros de cultura estrangeiros" (Ramos, 1953:10). Os intelectuais identificados com essa corrente estariam mais voltados para os conteúdos abstratos sem a atenção devida aos aspectos programáticos, operacionais. Fariam parte deste segundo grupo: Tobias Barreto, Pontes de Miranda, Tristão de Ataíde, Pinto Ferreira e Mario Lins (Ramos, 1953:11-12).

É interessante observar que o sociólogo baiano cria "um sub-ramo desta última corrente" (Ramos, 1953:12) que estaria voltada para os estudos do negro, ou seja, que faria do negro "material etnográfico" e da qual pertenceriam Nina Rodrigues, Gilberto Freyre, Arthur Ramos, Alfred Métraux, Donald Pierson, Roger Bastide, Emilio Willems e outros (Ramos, 1953:12-17). Estes autores veriam o negro "como uma espécie de múmia, e não na sua problematicidade política e social. Daí que, até certo ponto, eles tenham cooperado para distrair a atenção das elites do país do sentido programático do movimento abolicionista, tal como tinha sido delimitado por homens como Joaquim Nabuco" (Ramos, 1953:17).

Este novo exercício de classificação dos intelectuais no interior das ciências sociais revela uma mudança radical do sociólogo ante os escritos anteriores, especialmente Notícias sobre as Pesquisas e os Estudos Sociológicos no Brasil (1940-1949). Esta guinada se revela no cancelamento da divisão, cujo marco seria os anos 30, entre produção sociológica institucionalizada e a considerada "pré-científica", "ensaística". " Esta questão é bem evidente nas reflexões sobre o negro. Guerreiro considera que a sociologia acadêmica, ao fazer do negro "objeto de estudo", lembraria as pesquisas sobre as "sobrevivências africanas", tão criticadas por ele.

A partir de O Processo da Sociologia no Brasil suas indagações estarão embasadas no resgate de uma produção sociológica que viria desde o final do século XIX articulando questão racial e questão nacional. Neste sentido, a nova sociologia do negro de Guerreiro Ramos "contribui decisivamente para restabelecer a ponte de comunicação intelectual entre o passado e o presente no pensamento social brasileiro" (Schwartzman, 1983:31).

O sociólogo divide esta tradição entre aqueles que procuravam incorporar o negro à nação, embora com uma série de equívocos, de natureza racista, como os de Oliveira Viana; e os que com uma visão racista e pessimista, como a de Nina Rodrigues, não con- 
seguiam encontrar "um lugar para o negro" já que este ameaçaria a identificação entre os destinos da nação e a civilização branca e ocidental.

A identificação de Guerreiro com a vertente "'autenticamente nacional' sugere a existência de uma certa tensão, no pensamento do autor, entre o reconhecimento da diversidade étnica existente no País e a necessidade de sua diluição diante da necessidade de se construir uma identidade nacional. Esta posição seria reforçada em julho de 1953 no 11 Congresso Latino-americano de Sociologia ocorrido no Rio de Janeiro e em São Paulo no qual o sociólogo apresenta, como presidente da Comissão de Estruturas Nacionais e Regionais nesse Congresso, uma série de teses, recusadas em sua totalidade, sobre o que deveria ser o trabalho sociológico num país em processo de desenvolvimento. Isso faz com que Guerreiro estabeleça uma discussão pública, por meio do jornal Diário de Notícias, a respeito de suas idéias. Dentre as teses derrotadas pelo Congresso encontra-se uma especialmente dedicada a questão étnica:

\footnotetext{
É francamente desaconselhável que o trabalho sociológico, direta ou indiretamente. contribua para a persistência, nas nações latino-americanas, de estilos de comportamento de caráter préletrado. Ao contrário, no que concerne às populações indigenas ou afro-americanas, os sociólogos devem aplicar-se no estudo e na proposição de mecanismos de integração social que apressem a incorporação desses contingentes humanos na atual estrutura econômica e cultural dos países latino-americanos. (Ramos, 1957:78)
}

Pode-se observar, pelo texto acima, que a visão integracionista de Guerreiro, calcada no suposto êxito do processo de mudanças estruturais nas sociedades latino-americanas, encontra-se ainda fundamentada numa ambígua compreensão do significado do tema dos intercursos raciais em processo de desenvolvimento em contextos nacionais. Guerreiro reconhece o problema mas, ao mesmo tempo, cancela suas especificidades em face da importância da questão nacional.

O Congresso de 1953 teve conseqüências definitivas no pensamento de Guerreiro Ramos. A partir de então "a luta ideológica sobre o papel da sociologia e sobre os cânones necessários à produção dessa disciplina entram na ordem do dia" (Oliveira, 1995a:93-94). O tema das relações raciais não esteve ausente dos intensos debates ocorridos naquele momento.

A radiografia de Guerreiro Ramos do pensamento social brasileiro feita em 1953 foi aprofundada no ano seguinte, em virtude de sua reação às críticas de Costa Pinto ao TEN expostas em seu livro O Negro no Rio de Janeiro: relações de raças numa sociedade em mudança (Costa Pinto, 1953). Além de transformar textualmente o sociólogo mulato em objeto de estudo, na medida que o mesmo seria um dos ideólogos do TEN, Costa Pinto caracteriza o movimento negro como uma elite mergulhada num profundo dilema por estar nos estratos superiores da sociedade, mas não ser aceita de fato pelas "elites brancas". Além disso, afirma que a "ideologia da negritude" seria um "racismo às avessas" e que a "elite negra" se constituiria numa minoria totalmente descolada da "massa negra", não percebendo que a dicotomia entre raça e classe seria uma falsa questão. A análise de Costa Pinto, típica do marxismo dos anos 50, deslegitimaria um movimento de corte racial. Portanto, este estudo só viria a confirmar mais uma vez, segundo Guerreiro, a idéia de que a sociologia estaria impregnada de estudos no qual o negro seria transformado em "material etnográfico". 
A resposta de Guerreiro veio com o artigo entitulado O Problema do Negro na Sociologia Brasileira, concluído em fevereiro de 1954, dois meses após o lançamento do livro de Costa Pinto e publicado no primeiro semestre do mesmo ano em Cadernos de
Nosso Tempo, revista do IBESP, futuro ISEB.

Em O Problema do Negro, o autor retoma suas críticas, agora de modo mais detalhado, da literatura sobre as relações raciais no Brasil, afim de desnudar um tipo de trabalho antropológico e sociológico dominante até então. Com estas críticas, o sociólogo teve a intenção de apresentar o seu programa de uma sociologia nacional.

Logo na introdução, Guerreiro afirma que os estudos raciais são, em geral, alienados por seguirem parâmetros sociológicos voltados para a realidade européia e norteestariam comprometidos com "uma concepção quietista da sociedade e, assim, contribu[iriam] para a ocultação da terapêutica decisiva dos problemas humanos em países
subdesenvolvidos"' (Ramos, 1957:125).

Desse modo, lembrando O Processo da Sociologia no Brasil, Guerreiro aprimora que teria diferenças entre si, congregaria Silvio Romero, Euclides da Cunha, Alberto
Torres e Oliveira Viana. Eles estariam mais interessados em formular:

uma teoria do tipo étnico brasileiro do que em extremar as características peculiares de cada um dos contingentes formadores da nação. No que diz respeito ao elemento fecer qualquer tendência para ser ele considerado do anguto contribuiram para arrealgo estranho na comunidade. (Ramos, 1957:127-128) ângulo do exótico, ou como

Guerreiro ressalta nesses autores as idéias de evolução, de contexto histórico, de mudança presentes em seus escritos e, portanto, importantes de serem resgatadas. É o que se depreende da comparação que Guerreiro faz entre Euclides da Cunha e Nina Ro-
drigues:

[...] em matéria de relações de raça no Brasil, Euclides da Cunha equivocou-se tanto
quanto, por exemplo, Nina Rodrigues. E o que, entretanto, o diferencia do último e dos seus
seguidores são duas coisas: em primeiro lugar, a sua atitude crítico-assimilativa em face
da ciência estrangeira, que ele utilizou, sem passividade e sem basbaquice, mas com plena
lucidez, repensando os conceitos e as teorias, à luz dos fatos que coletava.
[...] Em segundo lugar, embora Euclides da Cunha tenha adotado os preconceitos da
antropologia racista, soube superar as suas conotações depressivas para os brasilei-
ros. Viu, por exemplo, o mestiço exatamente ao contrário do modo como Nina Rodri-
gues e Arthur Ramos viram o negro; viu os mestiços como brasileiros 'retardados',
como 'patrícios', como 'nossos irmãos' e não como elemento exótico, estranho out
mumificado. Ao contrário dos africanistas de mentalidade estática, acentuou o cará-
ter provisório de nosso quadro de relações de raça e apontou a terapêutica para alte-
rá-lo. (Ramos, 1957:132)

Cunha e Oliveira Viana positivos da história do país e sua sociedade, átém nesses autores a crença nos aspectos gularidade. Logo, o passado não condenaria além de chamarem a atenção para a sua sinLima, 1994). Portanto, Guerreiro poderia ser identuro da nação (Vianna, 1991, 1994; 
exerceu grande influência em autores como Silvio Romero, Alberto Torres, Oliveira Viana e Gilberto Freyre. O iberismo, segundo Vianna (1994:381), seria embasado nas "concepções organicistas e comunitaristas da ordem nacional e [teria] as suas reservas quanto ao individualismo e ao mundo livre dos interesses".

A tradição de pesquisa inaugurada por Nina Rodrigues seria atualizada, segundo Guerreiro, nos anos 30 com os estudos das "sobrevivências africanas" orientados por Arthur Ramos e por todos aqueles envolvidos nos congressos afro-brasileiros de Recife e Salvador em 1934 e 1937, respectivamente, entre os quais estariam Gilberto Freyre, Édison Carneiro e Aydano do Couto Ferraz. Esta lista foi acrescida por antropólogos brasileiros e estrangeiros inscridos no mundo universitário, o das ciências sociais institucionalizada, como Donald Pierson, Charles Wagley, Florestan Fernandes, Thales de Azevedo e Costa Pinto.

É interessante observar que parte dos cientistas sociais criticados por Guerreiro Ramos pertenciam ao projeto patrocinado pela UNESCO sobre as relações raciais no Brasil. Este projeto suscitou uma interessante confluência entre os propósitos da UNESCO e a presença de um grupo de pesquisadores brasileiros e estrangeiros que chegavam, em graus variados, à maturidade intelectual e profissional. Este processo não antecipado entre o desenvolvimento das ciências sociais no Brasil e a luta contra o racismo no contexto internacional possibilitou, no processo de democratização do País vivido entre 1946-1964, o surgimento de novas interpretações sobre as relações raciais no País e especialmente a revelação da discriminação racial em diversos níveis, frustrando, em parte, a expectativa inicial da UNESCO. ${ }^{5}$

$\mathrm{Na}$ verdade, Guerreiro coloca-se na contramão do padrão de institucionalização das ciências sociais vigente no Brasil à época. Afinal, este padrão veria o negro como objeto de estudo e, portanto, sem interesse algum em "transformar a condição humana do negro na sociedade brasileira (...)" (Ramos, 1957:128).

Nesse sentido, o aspecto mais importante a ser revisto pela "sociologia de intervenção" (Vianna, 1994:378) proposta por Guerreiro seria a própria idéia de conceber o negro como um problema na sociedade brasileira. Se os negros e mestiços professariam em sua maioria a religião católica, se alguns dos fenômenos sociais como a criminalidade adviriam da sua condição socioeconômica e não étnica, se não haveria nada de especificamente negro em sua conduta quer na vida associativa, conjugal, profissional ou mesmo no processo de competição econômico e político e, por fim, se o comportamento do negro é "sempre essencialmente como brasileiro, embora, como o dos brancos, esse comportamento se diferencie segundo as contingências de região e estrato social" (Ramos, 1957:149), qual seria o problema particular do negro?

A resposta de Guerreiro ao "problema do negro" comporta duas linhas de reflexão. A primeira diz respeito aos limites da democracia racial, que se revelariam na "ideologia da brancura" e na "patologia social do branco brasileiro". A "ideologia da brancura" foi definida por Guerreiro como uma crença de que "a cor da pele do negro parece constituir o obstáculo, a anormalidade a sanar. Dir-se-ia que na cultura brasileira o branco é o ideal, a norma, o valor, por excelência', (Ramos, 1957:150). (1953) e Ribeiro (1956). 
No centro desta ideologia estaria a estética branca assimilada pelas sociedades que sofreram a dominação colonial. Influenciado pelo etnocentrismo europeu, o brasileiro,

e especialmente, o letrado, adere psicologicamente a um padrão estético europeu e vê os acidentes étnicos do país e a si próprio, do ponto de vista deste. Isto é verdade, tanto com referência ao brasileiro de côr como ao claro. (Ramos, 1957:153)

Portanto, os estudos sociológicos e antropológicos sobre o negro elaborados até então não passariam de "documentos ilustrados da ideologia da brancura ou da claridade" (Ramos, 1957:154).

Ao incluir os brancos entre aqueles que seriam influenciados pela "ideologia da brancura", Guerreiro vai mais além afirmando que os mesmos sofreriam de uma verdadeira "patologia social". Esta "patologia', que seria uma crítica direta a Costa Pinto, grassaria especialmente no Nordeste, pontuado pela enorme dificuldade da classe dominante, inclusive os intelectuais, em reconhecer o cadinho racial brasileiro presente não somente no outro, mas em si próprio. Em outras palavras, segundo Guerreiro "o nosso branco é, do ponto de vista antropológico, um mestiço, sendo, entre nós, pequena minoria o branco não portador de sangue negro"' (Ramos, 1957:180).

A atitude reativa da minoria branca, ávida por preservar a sua condição de estirpe, de pureza racial, ante a um povo nitidamente mestiço, mascararia seu complexo de inferioridade, revelando assim uma combinação de anomalia e atraso. Diante de uma nação em intenso processo de urbanização e industrialização, que se traduziria pela mobilidade social vertical, contemplando em cheio os negros, a "patologia social do 'branco' brasileiro" seria sinônimo de antinação, "já que [inidicaria assim um] sintoma de escassa integração social de seus elementos..." (Ramos, 1957:191).

O sociólogo baiano acreditava que só uma sociologia operacionalizada por uma elite negra poderia atingir uma solução satisfatória no terreno das desigualdades raciais. Para isso, o pesquisador deveria " partir de uma situação vital [...] aberto à realidade fática e, também, aberto interiormente para a originalidade" (Ramos, 1957:156).

Dessa maneira, haveria o negro como objeto de estudo da sociologia institucionalizada e o negro como uma vivência, como uma subjetividade, enfim, como fonte essencial de uma "sociologia do negro em mangas de camisa". O Teatro Experimental do Negro representaria esta nova fase político-intelectual dos estudos sobre o negro. Ao elucidar as origens do TEN, Guerreiro apresenta o roteiro de uma possível história do movimento negro desde a colônia, por meio das diversas associações, insurreições, resistências e lutas pela libertação do negro.

A identificação dos limites da democracia racial no Brasil e a proposta de que os negros fizessem uma sociologia a partir de sua própria experiência converge para uma segunda linha de reflexão de Guerreiro sobre o "problema do negro". Esta reflexão contemplaria os estreitos vínculos entre relações raciais, desenvolvimento e identidade nacional. A valorização do negro estaria em sintonia com o momento vivido no Brasil na década de 50, no qual o País

por força do desenvolvimento de sua riqueza material e de sua crescente emancipação econômica, começa a ter o que se chama de caráter nacional, um orgulho nacional e, na medida em que este processo avança, torna-se verdadeiro imperativo categórico de nosso quadros intelectuais procurar aplicar-se na estilização, na valorização de nossos tipos étnicos. (Ramos, 1957:158) 
A perspectiva positiva da associação entre relações raciais e conformação definitiva de uma identidade nacional vislumbrada por Guerreiro a partir do processo de desenvolvimento econômico corresponderia

a nova fase dos estudos sobre relaçôes de raça no Brasil, fase que se caracteriza pelo enfoque de tais relações, desde um ato de liberdade do negro.

É minha conviç̧ão que desta mudança de orientação resulte, não um conflito insolível entre brancos e escuros, mas uma liquidação. de equivocos de parte a parte $e$. conseqüentemente, uma contribuição para que a sociedade brasileira se encaminhe para o rumo de sua verdadeira destinação histórica - a de tornar-se, do ponto de vista étnico, uma conjunctio oppositorium. (Ramos, 1957:159)

Pelo que se pode observar, esta "unidade de contrários" (conjunctio oppositorium) não seria a diluição das especificidades raciais e sim, como "água e azeite" (Araújo, 1994), a afirmação da diversidade num contexto de desenvolvimento econômico nacional. Só assim estaríamos diante da possibilidade de realização de uma democracia racial plena intimamente associada à construção definitiva da identidade nacional.

\section{DA RAÇA À NAÇÃO}

Na abordagem da temática racial há dois aspectos a serem destacados na sociologia militante de Guerreiro Ramos. O primeiro consiste na influência da psicologia social tendo em vista a valorização positiva da identidade negra ante a persistência da inferioridade social dos negros. Esta preocupação se consubstancia nas atividades culturais, nos exercícios de grupoterapia, nos concursos de beleza da mulher negra (Turner, 1992) e no concurso do Cristo Negro (Nascimento, 1966), remetendo assim a dimensão espiritual, católica, presente em Guerreiro, que se torna secular a partir do final dos anos 40 .

$\mathrm{O}$ segundo aspecto, de natureza eminentemente política, integracionista, apresentaria a seguinte questão: como incorporar plenamente os negros ao mundo da cidadania? Em vez de considerar a abolição da escravidão como ato político que alçaria o negro à condição cidadã, como as elites brancas acreditavam, Guerreiro supunha que a assimilação definitiva dos negros ao universo dos direitos ainda estaria por se realizar. Caberia a uma elite negra identificada com a tradição ocidental, de corte católico ou protestante, induzir a "massa negra" a lutar por direitos sociais e sensibilizar a classe dominante branca diante dessas demandas. Conforme o entendimento de Guerreiro, o Teatro Experimental do Negro, "uma elite de intelectuais de cor" (Ramos, 1952:1), teria assumido esta tarefa de superar a distância entre o "negro legal" e o "negro real", entre a libertação política formal e a manutenção das disparidades sociais e econômicas, em sintonia com a especificidade brasileira, que se traduziria por uma tradição católica tolerante e integradora, acompanhada de uma história de intensa miscigenação. Só assim haveria a implantação definitiva de uma verdadeira democracia racial no País.

Com a onda nacionalista dos anos 50 e a participação de Guerreiro no segundo Governo Vargas, a questão do negro aparece em sua obra com dois significados: primeiro, passa a ser um instrumento de posicionamento de Guerreiro no campo intelectual, com o surgimento da febre classificatória da intelectualidade brasileira, na qual a questão étnica será um referência central pelo menos até 1955; segundo, o tema das relações raciais passa a ser uma questão nacional. 
À crítica as "sobrevivências africanas" soma-se agora uma visão que não diluiria as especificidades raciais mas, pelo contrário, apostaria na superação do atraso, pré-condição para a constituição política do povo brasileiro. Como afirma Guerreiro:

Desde que se define o negro como um ingrediente normal da população do Pais, como povo brasileiro, carece de significação falar de problema do negro puramente económico, destacado do problema geral das classes desfavorecidas ou do pauperismo. O negro é povo, no Brasil.. [...] O negro no Brasil não é uma anedota, é um parâmetro da realidade nacional. (Ramos, 1952:157)

Portanto, os contrangimentos provocados pela " patologia social do 'branco' brasileiro" revelariam uma das contradições fundamentais pensadas à época: o conflito entre o padrão tradicional, atrasado, arcaico e o padrão moderno de desenvolvimento econômico-social. Elites brancas de regiões atrasadas não conseguiriam reconhecer a legitimidade do compósito racial existente no País. Esta situação de atraso se associaria com a "ideologia da brancura" que não seria mais do que a força do colonialismo, do etnocentrismo europeu sobre as nações em busca de seus próprios destinos. O padrão tradicional e etnocêntrico, diante da necessidade de se construir um caminho nacional autóctone, seria sinônimo de tudo que fosse antimoderno c antinação.

Guerreiro Ramos, identificado com a "herança ibérica", acreditava na existência de uma cultura democrática racial brasileira convivendo com doses elevadas de racismo no País. Esta tensa e contraditória realidade só seria resolvida a partir do momento que se levasse às últimas conseqüências o desafio de Alberto Torres, referência central de Guerreiro, de se construir em definitivo uma identidade nacional brasileira. Caberia aos intelectuais "como estrato social na vida pública" (Vianna, 1994:376) assumir essa tarefa.

Ao enfrentar este desafio, a partir de uma "sociologia pen[sada] com as mãos" (Villas-Bôas, 1989:2), Guerreiro apostou no fortalecimento de uma democracia substantiva (Vianna, 1994:379) inspirado no modelo nacional-desenvolvimentista cepalino. ${ }^{6} \mathrm{~A}$ sociologia de Guerreiro Ramos tem várias marcas do contexto histórico dos anos $40 \mathrm{e}$ 50. No entanto, as reflexões e desafios elaborados pelo intelectual baiano ainda são de extrema atualidade.

\section{AGRADECIMENTOS}

Agradeço a Nísia Trindade Lima e a Ricardo Ventura Santos pelas críticas ao texto.

\section{REFERÊNCIAS BIBLIOGRÁFICAS}

AZEVEDO, T., 1955. As Elites de Cor. São Paulo: Companhia Editora Nacional.

ARAÚJO, R. B., 1994. Guerra e Paz: Casa Grande \& Senzala e a Obra de Gilberto Freyre nos Anos 30. Rio de Janeiro: Editora 34. 
ARAÚJO, R. B., 1988. Totalitarismo e Revolução: O Integralismo de Plínio Salgado. Rio de Janeiro: Jorge Zahar Editor.

BASTIDE, R. \& FERNANDES, F., 1955. Brancos e Negros em São Paulo. São Paulo: Editora Anhembi.

COSTA PINTO, L. de A., 1953. O Negro no Rio de Janeiro: Relações de Raças numa Sociedade em Mudança. São Paulo: Companhia Editora Nacional.

LIMA, N. T., 1994. O passado nos condena? A herança ibérica no pensamento de Oliveira Vianna, Gilberto Freyre e Sergio Buarque de Holanda. XVIII Encontro Anual da ANPOCS, Caxambu, Minas Gerais.

MAIO, M. C., 1992. Nem Rothschild, Nem Trotsky: o Pensamento Anti-Semita de Gustavo Barroso. Rio de Janeiro: Editora Imago.

MAUÊS, M. A. da M., 1988. Entre o branqueamento e a negritude: o TEN e o debate da questão racial. Dionysios, 28:89-101.

MICELI, S., 1989. História das Ciências Sociais no Brasil, vol.1. São Paulo: IDESP, EduSP, FINEP.

MORSE, R., 1988. O Espelho de Próspero. São Paulo: Companhia das Letras.

NASCIMENTO, A., 1950. O teatro experimental do negro e seu instituto de pesquisa sociológica. In: Relações de Raça no Brasil (A. G. Ramos, org.), pp. 27-32. Rio de Janeiro: Edições Quilombo.

NASCIMENTO, A., 1950a. Cartaz: Guerreiro Ramos. Rio de Janeiro: Quilombo, ano II, no 9, p.2.

NASCIMENTO, A., 1966. Teatro Experimental do Negro: Testemunhos. Rio de Janeiro: Editora GRD.

NASCIMENTO, A., 1982. O Negro Revoltado. Rio de Janeiro, Editora Nova Fronteira, 2a edição.

NASCIMENTO, A., 1995. Abdias Nascimento (Depoimento a Marcos Chor Maio).

NASCIMENTO, A. \& NASCIMENTO, E. B., 1991. Africans in Brazil: A Pan-African Perspective. New Jersey: Africa World Press, Inc.

OLIVEIRA, L. L., 1995a. A Sociologia do Guerreiro. Rio de Janeiro: Editora da UFRJ.

OLIVEIRA, L. L., 1995b. As Ciências Sociais no Rio de Janeiro. In: História das Ciências Sociais (S. Miceli, org.), pp. 233-307, vol.2. São Paulo: Editora Sumaré/FAPESP.

PEIRANO, M. G. e S., 1981. The Anthropology of Anthropology: the Brazilian Case. Ph.D Thesis, Harvard University.

RAMOS, A. G., 1939. Introdução à Cultura. Salvador: Cruzada da Boa Imprensa.

RAMOS, A. G., 1948. Imigração e preconceito. Rio de Janeiro: A Manhã, 4/7/1948.

RAMOS, A. G., 1950. O negro no Brasil e um exame de consciência. In: Relações de Raça no Brasil (A. G. Ramos, org.), pp. 33-46. Rio de Janeiro: Edições Quilombo.

RAMOS, A. G., 1950a. Os estudos sobre o negro brasileiro. Rio de Janeiro: A Manhã, 10/12/1950. 
RAMOS, A. G., 1950b. Apresentação da negritude. Rio de Janeiro: Quilombo, ano II, no 10 p.11.

RAMOS, A. G., 1950c. Uma experiência de grupo-terapia. In: Relações de Raça no Brasil (A. G. Ramos, org.), pp. 21-25. Rio de Janeiro: Edições Quilombo.

RAMOS, A. G., 1952. Um herói da negritude. Diário de Notícias, 06/04/1952, Suplemento Literário, p.1.

RAMOS, A. G., 1953. O Processo da Sociologia no Brasil. Rio de Janeiro (Edição do Autor).

RAMOS, A. G., 1957. Introdução Crítica à Sociologia Brasileira. Rio de Janeiro: Editorial Andes Limitada.

RAMOS, A. G. \& GARCIA, E. da S., 1949. Noticias sobre as Pesquisas e os Estudos Sociológicos no Brasil. Rio de Janeiro: Conselho de Imigração e Colonização.

RIBEIRO, R., 1956. Religião e Classes Sociais. Rio de Janeiro: Ministério da Educação e Cultura.

SANTOS, W. G., 1978. Ordem Burguesa e Liberalismo Político no Brasil. São Paulo: Duas Cidades.

SARTRE, J. P., 1965. Reflexões sobre o Racismo. São Paulo: Difel.

SCHWARTZMAN, S., 1983. Contribuição de Guerreiro Ramos para a sociologia brasileira Primeiro Painel. Revista de Administração Pública, 17:30-32.

SCHWARTZMAN, S., 1981. O Pensamento Nacionalista e os Cadernos de Nosso Tempo. Brasília: Editora da Universidade de Brasília.

SOARES, L. A., 1995. Guerreiro Ramos: a trajetória de um pensamento. Revista de Administração Pública, 29:33-50.

TURNER, D. J., 1992. The teatro experimental do negro and its black beauty contests. AfroHispanic Review, 11:76-81.

TRINDADE, H., 1979. Integralismo: o Fascismo Brasileiro na Década de 30. São Paulo: Ed. Difel.

VILLAS BÔAS, G., 1989. O sentido das mudanças na sociologia dos anos 50. XIII Encontro Anual da Anpocs, Caxambu, Minas Gerais.

VIANNA, L. W.; CARVALHO, M. A. R. \& MELO, M. P. C., 1994. Ciências sociais e vida pública. Dados, 37:357-403.

VIANNA, L. W., 1991. Americanistas e iberistas: a polêmica de Oliveira Vianna com Tavares Bastos. Dados, 34:145-189.

WAGLEY, C:, 1952. Race and Class in Rural Brazil. Paris: Unesco. 


\title{
11 DILEMAS DO BRASIL MODERNO: A QUESTÃO RACIAL NA OBRA DE FLORESTAN FERNANDES
}

\author{
Maria Arminda do Nascimento Arruda
}

No conjunto da reflexão de Florestan Fernandes sobre as relações raciais no Brasil, o livro A Integração do Negro na Sociedade de Classes ocupa posição incontestável. Trabalho mais alentado nascido da lavra do sociólogo neste campo, a obra expressa o amadurecimento das suas análises referentes à condição social dos ex-escravos e descendentes e demarca um momento de viragem na sua compreensão do Brasil. A Integração do Negro na Sociedade de Classes coroa um processo de reflexão e, ao mesmo tempo, aponta para problemas e temas futuros, a serem contemplados pelo autor.

Se as preocupações de Florestan com o preconceito racial originam-se das suas primeiras pesquisas sobre o folclore na cidade de São Paulo, realizadas entre 1941 e 1944 , apenas no decênio de 1950, a partir do Projeto UNESCO, o assunto ganha corpo no âmbito da sua sociologia (Fernandes \& Bastide, 1959). A questão percorreu a sua vida intelectual anos a fio, transformando-se em fonte para vários trabalhos voltados ao entendimento dos impasses oriundos da experiência da escravidão, na gênese e desenvolvimento da sociedade brasileira (Cardoso, 1962; Ianni, 1962; Franco, 1964). Florestan dirigiu as suas indagações na caracterização dos dilemas presentes na constituição da ordem capitalista no Brasil, evidentes na marginalização dos negros e mulatos, desembocando na realização parcial dos requisitos inerentes à sociedade moderna. É no quadro dessas perguntas que se insere $A$ Integração do Negro na Sociedade de Classes.

Situando a problemática na passagem da sociedade tradicional para a sociedade de classes, o sociólogo investiga a situação dos negros no prisma das formas sociais excludentes e das possibilidades de integração. A eleição da cidade de São Paulo como universo empírico privilegiado justifica-se, por tratar-se do...

primeiro centro urbano especificamente burguês. Não só prevalecia entre os homens uma mentalidade marcadamente mercantil, com seus corolários característicos - $o$ afã do lucro e a ambição do poder pela riqueza. Pensava-se que o 'trabalho livre' e a 'iniciativa individual' e o 'Iiberalismo econômico' eram os ingredientes do 'progresso', a chave que iria permitir superar o 'atraso do País' propiciar a conquista dos foros de 'nação civilizada' pelo Brasil. (Fernandes, 1965, 1:4-5)

Nesse quadro, a obra analisa as vicissitudes dos negros e mulatos para inserirem-se na nova ordem social, pontuada pelo "estilo de vida individualista e competitivo", construído pelo "novo regime de relações de produção" (Fernandes, 1965, I:8). Nesse andamento, o ordenamento do texto segue a proposta de análise.

Publicada em dois volumes, a obra encerra dois momentos periodizadores, segundo a dinâmica histórica inaugurada após a abolição. O primeiro volume - $O$ Legado da 
Raça Branca - compreende três capítulos, quais sejam, O Negro na Emergência da Sociedade de Classes; Pauperização e Anomia Social; Heteronomia Racial na Sociedade de
Classes:

A primeira parte, abrange o periodo que vai de 1880 a 1930. O primeiro capítulo toma a fase crucial da desagregação do regime servil e da emergência da ordem social competitiva - 1880 a 1900. Os dois capítulos subseqüentes lidam com a fase imediatamente ulterior, de consolidação da ordem social competitiva, sob forte persistência da concepção tradicionalista do mundo, de 1900 a 1930. (Fernandes, 1965, I:XII)

Neste volume, em suma, o autor parte da desagregação da relação escravista, da formação da ordem capitalista que se mescla a uma visão tradicionalista de mundo. $O$ período seguinte, 1930 a 1960, quando se consolida e expande a ordem social competitiva, objeto do segundo volume, Florestan reavalia as formas de absorção do negro no âmbito da industrialização. O volume - No Limiar de uma Nova Era - é composto dos seguintes capítulos: Os Movimentos Sociais no "Meio Negro"; Impulsões Igualitárias de Integração Racial; O Problema do Negro na Sociedade de Classes, que anunciam a perspectiva adotada, segundo os próprios títulos aludem. No todo, a referência conceitual reside na noção de ordem social competitiva, a guiar a interpretação e a organizar a nar-
rativa.

No primeiro volume o autor centra o foco de análise na condição de marginalidade dos negros ante aos novos padrões sociais inerentes à sociedade capitalista. $\mathrm{O}$ ex-escravo "surgia como uma figura deslocada e aberrante no cenário tumultuoso que se forjava graças à 'febre do café' (Fernandes, 1965, I:5). A rápida transformação da cidade de São Paulo, ocorrida entre o fim do século XIX e começo do século XX, impossibilitou a inserção dos negros ao estilo urbano de vida. Deixados à própria sorte, os egressos da situação cativa não seriam capazes de mobilizar as novas regras sociais, condição indispensável na sua transformação em agentes livres de trabalho. Deslocados da seara da competição por ocupações, os negros não conseguiram enfrentar os imigrantes, por estarem infensos às normas intrínsecas da sociedade em emergência. Marcados pela pau-
perização e desorganização,

viveram dentro da cidade, mas não progrediram com ela e através dela. Constituiam uma congérie social, dispersa pelos bairros, e só partilhavam em comum uma existência árdua, obscura e muitas vezes deletéria. Nessa situação, agravou-se, em lugar de corrigir-se, o estado de anomia social transplantado do cativeiro. (Fernandes,
1965, I:71)

Em outros termos, a heteronomia da "situação de castas" impediu aos negros assimilarem as potencialidades presentes numa "situação de classes".

O ritmo intenso de urbanização da cidade de São Paulo impunha a reintegração, após a extinção da escravatura, exigindo formas de ajustamento ao regime da produção capitalista nas suas expressões econômica, social e política. A exclusão dos negros e mulatos desse processo corroeu os fundamentos jurídicos e morais das relações contratuais,

projetando-os no seio da plebe sem livrá-los dos efeitos diretos ou indiretos dessa classificação. Em plena fase de consolidação da ordem social competitiva e do regime de classes, a 'população de cor' subsiste numa posição ambígua, representada, confusamente, como se constituisse um estamento equivalente ocupado pelos 'libertos' na velha estrutura social. (Fernandes, 1965, I:193) 
O centro dinâmico da sociedade em formação girará em torno das personagens centrais do fazendeiro e do imigrante, aguçando as dificuldades de ajustamento dos negros, vedando-lhes o acesso aos princípios da socialização emergente. $\mathrm{Na}$ base de tal processo, encontram-se o "desajustamento estrutural" e a "desorganização social" típicos da condição de negros e mulatos, não se operando a reclassificação no âmbito da sociedade. A vivência dos estados de anomia e heteronomia, por parte desse contigente de marginalizados, diluiu a construção da nova identidade que, em última instância, sequer se forma. Relegados após a escravidão, produziram, no momento seguinte, situação aberrante nos quadros da nova sociedade, por perpetuarem princípios passadistas de formação das posições e papéis sociais.

O regime extinto não desapareceu por completo após a abolição. Persistiu na mentalidade, no comportamento e até na organização das relações sociais dos homens, mesmo daqueles que deveriam estar interessados numa subversão total do antigo regime. (Fernandes, 1965, I:193)

Explicita-se, nessas passagens, determinada compreensão da história brasileira, cujo ritmo de transformação não se fez pela eliminação dos ditames da velha sociedade, ao contrário, mesclam-se à nova dinâmica. A convivência de tempos diversos...

indica claramente que a ordem social e a ordem racial da sociedade inclusiva se transformavam com intensidade bem desiguais ... Como se o modelo da organização de castas ainda imperasse, o setor constituido pelo estoque racial 'branco' engrenava-se nos fluxos das transformações históricas da ordem social, enquanto o estoque racial 'negro' permanecia estagnado e as interrelações dos dois continuavam a ser reguladas pelos velhos padrões. Proscrito da história e da participação das pugnas sociais que decidiam do seu curso, o 'homem de cor' estava bloqueado em uma zona estagnada e estática da sociedade. Por isso, em contraste com a alteração tumultuosa do cenário histórico-social, a ordem racial tendia a manter-se em estado estacionário. (Fernandes, 1965, I:206)

A esse fenômeno de demora cultural, de persistência de relações arcaicas, corresponde à identidade negra não constituída e à captura da condição de sujeitos:

Desse ângulo, as debilidades históricas, que cercaram a formação e o desenvolvimento inicial do regime de classes, contam como muito mais decisivas para a preservação de grande parte da antiga ordem racial, que as predisposições do 'branco' de precaver-se do 'negro livre'. Pura e simplesmente, aquele não se defrontou com semelhante alternativa histórica, como aconteceu, por exemplo, em situação análoga nos Estados Unidos. (Fernandes, 1965, I:195)

A contraface da ausência de lugar do negro na nova ordem reside no mito da democracia racial, analisado no último capítulo.

A desmontagem da crença numa sociedade racialmente aberta faz-se na demonstração da ausência de correlação entre estrutura social e organização racial, patente na transformação da ordem jurídico-política, porém de caráter formal e restrito.

Como as oportunidades de competição subsistiam potencialmente abertas ao 'negro', parecia que a continuidade do paralelismo entre a estrutura social e a estrutura racial da sociedade brasileira constituía uma expressão clara das possibilidades relativas dos diversos estoques raciais de nossa população ... Imposto de cima para baixo, como algo essencial à respeitabilidade do brasileiro, ao funcionamento nor- 
mal das instituições e ao equilibrio da ordem nacional, aquele mito acabou caracterizando a 'ideologia racial brasileira', perdendo-se por completo as identificações que o confinavam à ideologia e às técnicas de dominação de uma classe social. (Fernandes, 1965, I:198)

Caracterizada como consciência falsa a construção racial imperante no Brasil, o autor conecta-a à realidade das classes dominantes que, por essa via, mantinham seus privilégios e prerrogativas, aguçando a distância social e retendo o desenvolvimento da ordem social competitiva. A dominação patrimonialista correspondente atesta, em suma, o caráter cambiante do estilo de vida democrático e da ordem social com ele sincronizada.

No quadro dessas considerações, explicitam-se concepções do autor: a noção de ordem social competitiva, ou de sociedade capitalista, enquanto forma de estratificação aberta e tendencialmente democrática; ${ }^{1}$ a identificação do mito à ideologia, numa acepção mais restrita a esse fenômeno de natureza simbólica. Nesse sentido, Florestan trabatha com a noção de mito no sentido diverso da tradição antropológica, ou seja, enquanto universo de representações exclusivas. De outro lado, a discussão do mito da democracia racial permite-lhe ultrapassar certas visões dominantes e "representa uma recusa à visão conservadora que marca o debate não somente sobre a questão racial, mas também na Sociologia no Brasil" (Bastos, 1987:141). No interior desses parâmetros analíticos, o sociólogo desenvolve a segunda parte da sua reflexão, quando a ordem social competitiva expande-se no sentido capitalista no momento da segunda revolução industrial, o que possibilita o reequacionamento das formas de integração do negro.

O entrecruzamento entre cor e estratificação socioeconômica, ao pautar o desenvolvimento do segundo volume, leva o autor a pensar as modalidades de inserção dos negros e mulatos que começam a ocorrer de modo paulatino, através da distribuição das ocupações. Trata-se de compreender como as relações raciais, pervertidas e assimiladas pelos padrões tradicionalistas, passam cada vez mais a ser alteradas através dos movimentos oriundos do meio negro. Um processo social que, embora tímido, representava formas de reação ao modus-vivendi. No passado,

o 'negro' vivia numa sociedade organizada em classes sem participar do regime de classes. O termo 'preto' permitia selecionar a cor como marca racial para distinguir, a um só tempo, um estoque racial e uma categoria social em situação societária ambigua, para não dizer francamente marginal. (Fernandes, 1965, I:219)

Em outros termos, impunha-se acompanhar os desdobramentos dos dois grandes dilemas sociais, vividos pelos negros, no período anterior.

Primeiro, havia o dilema da absorção da 'população de cor' às formas de vida social organizadas imperantes na ordem social competitiva ... Segundo, havia o dilema do 'preconceito de cor' ou seja, no que isso significa na sociedade brasileira, da perduração da velha associação entre cor e posição social infima a qual excluía o 'negro', de modo parcial ou total (conforme os comportamentos e os direitos sociais considerados) da condição de gente. (Fernandes, 1965, II:1)

Pude explorar esta dimensão da análise de Florestan após a leitura do texto de Guimarães (neste volume). 
O protesto negro, muito embora não fosse suficientemente forte para superar as desigualdades raciais, explicita a construção de uma nova era histórica, na qual os herdeiros do cativeiro começam a afirmar-se como homens livres e cidadãos.

A emergência plena dos direitos, todavia, enfrentava as barreiras de uma sociedade pouco permeável aos movimentos de integração, visíveis na rejeição à participação coletiva, mantendo o desequilíbrio entre ordem social e sistema racial dominante. Impôs-se formas individuais de ajustamento que ultrapassavam, com atraso considerável, certos entraves à classificação, mesmo que as posições auferidas se situassem no nível inferior da estratificação:

Por pouco que isso pareça, em termos sociológicos estamos diante de uma ten-
dência bem definida. À medida que ela se concretiza, o 'negro' supera, graças ao seu
esforço, a antiga situação de pauperismo e de anomia social, deixando de ser um
marginal (em relação ao regime de trabalho) e um dependente (em face do sistema
de classificação social). (Fernandes, 1965, II:134)

Em síntese, a desocupação e a semi-ocupação perdem intensidade, o que não significa ipso-facto a eliminação de atitudes descriminatórias. A via individualizada de ascensão social faz dos descendentes dos escravos presas do preconceito, visto que buscam, muitas vezes, se livrar da "condição de negro". A luta por uma situação de classe travada pelos negros delineia possibilidades de instituir um novo destino social, de absorver as "oportunidades potenciais de uma sociedade aberta" (Fernandes, 1965, II:278).

Apesar da tendência à assimilação, o prestígio e o poder permanecem enleados aos princípios sociais dominantes herdados do passado e encarcerados pela ordem branca. A lentidão e descontinuidade do ritmo da integração apontam para os dilemas de uma história que não rompe as cadeias do passado. No âmbito da sociedade de classes, apesar do nuançamento da relação entre negro e condição social ínfima, os egressos da escravidão não se constituíram em ameaça às posições do branco e sequer entraram no universo das percepções deste. "Por conseguinte, não são interesses de classe que interferem nas manifestações do 'preconceito de cor'" (Fernandes, 1965, II:288). Na impossibilidade de constituir-se, efetivamente, em sujeito da sua trajetória social, o negro vivencia uma realidade do preconceito contraditória, que pode ser tanto neutralizada, quanto acirrada, em função da tradição cultural da sociedade. Esta via de ligação entre o passado, o legado cultural da sociedade escravista e o presente sofre as injunções de circunstâncias e não foi gestada na dinâmica intrínseca à ordem social competitiva. A atualização dos estereótipos resultam de traços culturais e, na medida em que os negros não se transformaram em uma realidade que se antepôs aos brancos, estes puderam ignorá-la, acentuando a inércia da integração. A ética mascarada, característica dos brancos, expõe a insensibilidade diante da discriminação e do descompasso entre estereotipação negativa e princípios ideais; exprime a tenacidade do modelo tradicionalista de relação racial; atesta a autocomplacência do branco que só rejeita as manifestações ostensivas, mas não o pre-
conceito.

As expressões de preconceito do branco se não nascem completamente do presente, não romperam integralmente com o passado:

A mudança social progressiva afetou o antigo sistema de relações raciais, sem contudo abalá-lo profundamente ou substitui-lo por algo mais ajustado aos requisitos materiais e morais da ordem social competitiva. Em conseqüencia, as técnicas de 
controle social, que canalizam, disciplinam e orientam os mecanismos de reação societária ao 'preconceito de cor', ou são obsoletas e anacrônicas (como expressão direta de um estado extremo de demora cultural), ou são inconsistentes e débeis, estando longe de responder às exigências de uma ordem social competitiva (e, por isso mesmo, aberta e democrática pelo menos em alguns níveis da organização social). (Fernandes, 1965, II:381)

Se as manifestações ostensivas do preconceito são afastadas, no andamento da crise da visão tradicionalista, não se desvenda a realidade das relações raciais e o "preconceito de não ter preconceito" é o véu que encobre a visão dos que não querem perceber, daqueles que ignoram, pois imaginam que o problema reside em controlar a discriminação por ser um dever humanitário. O preconceito de não ter preconceito particulariza as expressões de alheamento do branco em relação ao drama do negro e revela a especificidade da discriminação no Brasil, cujo reconhecimento rompe a construção mítica da democracia racial.

No andamento desta análise, Florestan Fernandes constrói o problema crucial do livro, presente no modo como relacionou a condição do negro na formação e expansão da sociedade de classes. A persistência do padrão de relações étnicas do passado impede a que a ordem social competitiva controle e redirecione as formas de ajustamento racial, criando obstáculos à realização plena da nova moralidade, transformando-a em "autêntico e fechado mundo dos brancos" (Fernandes, 1965, II:389). Em suma, não se construiu no Brasil uma ordem burguesa aberta e democrática, como ocorreu em outros países, mas uma ordem burguesa enrijecida e tendente ao autoritarismo. Na gênese da sociedade de classes no Brasil imiscuem-se os traços do passado, dificultando a plena constituição da ordem social competitiva, apesar do paulatino movimento de integração. Configura-se o dilema racial brasileiro patente no modo fragmentário e incompleto de absorção; evidente na crença da inexistência do preconceito, conformando um fenônemo social de natureza "sociopática". Em outros termos, na história da formação da ordem competitiva estabelecem-se descontinuidades, uma junção de elementos em si mesmos distintos, responsáveis pela criação de uma síntese de contrários. No interior dessa realidade contraditória, o encaminhamento da questão do negro é decisivo para fundamentar uma sociedade moderna e democrática.

O enquadramento do tema, no âmbito da dinâmica histórica, produz uma visão abrangente da sociedade brasileira que será retrabalhada em obras como Sociedade de Classes e Subdesenvolvimento, Capitalismo Dependente e Classes Sociais na América Latina, culminando em A Revolução Burguesa no Brasil:

O estudo do negro e das relações raciais ... não representa, pois, algo secundário ou marginal, mas ... o problema concreto de onde partem as suas reflexões posteriores, sua análise da formação e da evolução da sociedade brasileira. (Lépine, 1987:130)

Por essa razão, A Integração do Negro é obra de clivagem, não apenas no que tange à maneira como Florestan enfrenta a questão das relações raciais, mas, sobretudo, no que se refere ao caráter maduro e ao olhar ampliado vertido sobre a sociedade brasileira. O tema da revolução burguesa, manifesto no livro, será objeto de reflexão exclusiva no futuro. A noção de ordem social competitiva, central ao andamento das suas análises e que the permite trabalhar com as especificidades da nossa constitui- 
ção histórica, através da formação do mercado capitalista e das classes, encontra-se desenvolvida no texto.

Ao longo das páginas de $A$ Integração do Negro, o autor enfrenta um problema iminentemente sociológico, qual seja, o da emergência das classes no contexto de uma sociedade pontuada pelo tradicionalismo, defrontando-se com uma questão de difícil equacionamento: a conciliação entre civilização burguesa que envolve ética racional, competição, igualdade legal-formal, mobilidade e a persistência de princípios estamentais de estratificação e do patrimonialismo. A classificação social emerge, assim, no interior da ordem social competitiva como expressão do mundo burguês, onde constitui-se o plano propriamente do social. Aí ocorrem o funcionamento e a diferenciação do sistema produtivo e as modalidades de adaptação às potencialidades econômicas e socioculturais. As formas de proximidade e de afastamento entre estas dimensões respondem pela historicidade, ao produzirem padrões típicos de estruturação. No caso da análise da inserção dos negros na sociedade de classes ocorreu um fracionamento das exigências de adaptação à nova realidade, limitando o acesso às oportunidades. A demora cultural é indício da dificuldade de integração e da ausência de efetiva assimilação. A raiz do problema subjaz nestes descompassos.

No livro Sociedade de Classes e Subdesenvolvimento a análise do regime de classes revela peculiaridades, ao não dar...

origem a um mínimo de homogeneidade e de eqüidade na distribuição das probabilidades de valorizar no mercado o poder de possessão de bens e de trabaIho', base na qual se poderá construir um estratificação social de fundamentos univocamente económicos. (Fernandes, 1968:80)

Em Capitalismo Dependente e Classes Sociais na América Latina a mesma pontuação aparece ao não se produzir um processo de homogeneização social "quanto a padrões de vida, aspirações sociais e orientações de valor" (Fernandes, 1973:93). E em $A$ Revolução Burguesa no Brasil a particular relação ocorrida impediu o florescimento da ordem social competitiva, isto é, de posições sociais e de condutas orientadas segundo os princípios correntes do "capitalismo como estilo e vida" (Fernandes, 1975:146). O drama desenrolado na emergência do tipo social burguês desemboca na presença de uma burguesia sem utopia, que não constrói a nação e não desenvolve os requisitos inerentes ao seu mundo. No terreno destas identidades difusas, a sua compreensão da história do Brasil exprime-se na problemática do bloqueio do moderno, dos mecanismos que entravam a modernização, construindo o universo das especificidades da nossa sociedade. Este sentido último da história brasileira gestou-se no solo da crise da ordem escravista e senhorial, quando as estruturas arcaicas articularam-se às modernas e restringiram a difusão das relações contratuais. A análise da situação social do negro, por isso, é fundamental ao entendimento da "questão do destino que se pretendia dar à ordem social competitiva e à sociedade de classes no Brasil'" (Fernandes, 1965, I:18).

E aqui delineia-se a importância de $A$ Integração do Negro no universo das reflexões de Florestan Fernandes sobre o Brasil. Enquanto nessa obra o autor localiza as dificuldades para a realização dos princípios da ordem social competitiva e que envolvem a existência de uma estrutura de classes aberta e tendencialmente democrática, nos livros posteriores o diagnóstico é diverso. Ou seja, acentua-se a presença dessa identidade problemática, de difícil enquadramento, restritiva quanto à efetivação dos processos sociais 
típicos. Se na primeira obra não havia motivos para grande otimismo, nas posteriores o pessimismo é flagrante e expressa-se na descrença sobre a possibilidade de vigência da estratificação aberta das classes, diante da constatação do enrijecimento da estrutura social combinado à realidade autocrática de exercício do poder político. Às dificuldades internas da modernização acopla-se a ingerência externa, inibindo o pleno florescimento da ordem social competitiva e dissociando capitalismo e democracia. Daí, a noção de capitalismo dependente, no qual o Estado passa a ser a espinha dorsal das transformações e a distribuição do poder migra da ordem social competitiva. Nesse passo, a compreensão da ordem social competitiva, se estava primordialmente inspirada em Max Weber, através da categoria de ordem econômica, cede lugar para a compreensão das classes na acepção de Marx que envolve a presença das relações de dominação, inerentes ao caráter desigual da estratificação formada na produção.

A forte presença externa no desenvolvimento da história brasileira, desde a sua origem, torna a análise de Florestan Fernandes tributária de Caio Prado Júnior, da noção de "“sentido da colonização', categoria analítica básica, é apreendido através da inserção do objeto ... num todo maior, ou seja, os mecanismos comerciais da expansão européia" (Novais, 1986: 19). No bojo desta expansão, a escravidão, peça fundamental do empreendimento, aloja-se destruindo a cultura dos escravos, transformando-os em agentes passivos, "deturpa-se pelo estatuto social, material e moral a que se vê reduzido seu portador' (Prado Jr., 1961:270). Em A Integração do Negro os estados de heteronomia e anomia dos egressos da escravidão seriam agravados pelo passado que desenraizou a cultura negra, destruidor da identidade do africano. Nos livros posteriores, a dependência da sociedade brasileira dos centros dinâmicos do capitalismo enfraquece, ainda mais, os princípios da ordem social competitiva e rebaixa o caráter da "civilização burguesa", acentuando as suas perversidades. O resultado é a persistência "de três padrões distintos de desenvolvimento econômico, social e cultural, cada um comportando, por sua vez, padrões correspondentes de funcionamento e de crescimento da economia, da sociedade e da cultura" (Fernandes, 1975:75). Por isso, a ordem social competitiva, em sociedades como a brasileira, é fluída do ponto de vista das diferenças e da solidariedade de classes, além de diversificar aspirações e valores sociais. Nesse diapasão, Florestan Fernandes consegue elucidar as relações contraditórias subjacentes a uma totalidade composta por elementos em si mesmos diversos, aproximando-se de sugestões presentes na obra Raizes do Brasil, pois, segundo Antônio Cândido, Sérgio Buarque de Holanda rompe com visões dicotômicas e trabalha, dialeticamente, com as oposições (Cândido, 1963, Prefácio).

O dilema racial brasileiro, tal como caracterizado por Florestan, espelha o drama de uma história singular, por não desenvolver as possibilidades mais avançadas contidas na dinâmica da sua transformação. E o avanço identifica-se com as formas democráticas e de participação igualitária, configurando uma análise lastreada na perspectiva das classes populares. O próprio autor reconhece em A Integração do Negro a presença de "um constante esforço de projeção endopática na situação humana do negro e do mulato", mas alerta que procurou "evitar, cuidadosamente, que esse estado de espírito interferisse nas interpretações" (Fernandes, 1965, I:XIV). Em texto posterior, assumiu:

aceitávamos, abertamente, uma identificação moral e política com o negro, como condição intelectual para que nóssa contribuição se inserisse no processo de criação 
de uma verdadeira democracia racial - mas por mais que preteridessemos nos superar, tivemos que cair nas malhas do conhecimento científico, circunscrito e especializado. (Fernandes, 1976:68)

A nuance encerrada nos dois depoimentos exprime o percurso da sua reflexão, no qual A Integração do Negro na Sociedade de Classes é ponto de chegada e de partida.

\section{REFERÊNCIAS BIBLIOGRÁFICAS}

BASTOS, É. R., 1987. A questão racial e a revolução burguesa. In: O Saber Militante. Ensaios sobre Florestan Fernandes (Maria Angela DIncao, org.), pp.140-150, São Paulo: Editora Paz e Terra/UNESP.

CÂNDIDO, A., 1963. Prefácio. In: Raizes do Brasil (S. B. de Holanda), pp. IX-XI. 4a ed. Brasília: Editora Universidade de Brasília.

CARDoso, F. H., 1962. Capitalismo e Escravidão no Brasil Meridional. São Paulo: Difusão Européia do Livro.

FERNANDES, F., 1965. A Integração do Negro na Sociedade de Classes. 2 vol. São Paulo: Editora Dominus/USP.

FERNANDES, F., 1968. Sociedade de Classes e Subdesenvolvimento. Rio de Janeiro: Editora Zahar.

FERNANDES, F., 1973. Capitalismo Dependente e Classes Sociais na América Latina. Rio de Janeiro: Editora Zahar.

FERNANDES, F., 1975. A Revolução Burguesa no Brasil. Ensaio de Interpretação Sociológica. Rio de Janeiro: Editora Zahar.

FERNANDES, F., 1976. Circuito Fechado. Quatro Ensaios sobre o "Poder Institucional". São Paulo: Editora Hucitec.

FERNANDES, F. \& BASTIDE, R., 1959. Brancos e Negros em São Paulo. São Paulo: Companhia Editora Nacional.

FRANCO, M. S. C., 1964. Homens Livres na Ordem Escravocrata. São Paulo: Inst. de Est. Brasileiros, USP.

IANNI, O., 1962. As Metamorfoses do Escravo. São Paulo: Difusão Européia do Livro.

LÉPINE, C., 1987. A imagem do negro. In: O Saber Militante. Ensaios sobre Florestan Fernandes (Maria Angela D'Incao, org.), pp. 129-139, São Paulo: Editora Paz e Terra/UnesP.

NOVAIS, F. A., 1986. Caio Prado Jr. na historiografia brasileira. In: Inteligência Brasileira (M., Antunes e Ferrante, org.), pp. 9-27, São Paulo: Editora Brasiliense.

PRADO Jr., C., 1961. Formação do Brasil Contemporâneo. Colônia. São Paulo: Editora Brasiliense. 


\section{Parte IV}

\section{PERSPECTIVAS CONTEMPORÂNEAS ACERCA DA QUESTÃO RACIAL}




\section{AS RELAÇÕES RACIAIS EM CASA-GRANDE E SENZALA REVISITADAS À LUZ DO PROCESSO DE INTERNACIONALIZAÇÃO E GLOBALIZAÇÃO \\ Lívio Sansone}

\section{INTRODUÇÃO}

O sistema racial, formado pela terminologia classificatória da cor e pelas "regras" do sistema de relações raciais, é historicamente determinado e, ao mesmo tempo, reformula-se no dia-a-dia das relações raciais. No caso brasileiro, no qual ao racismo pouco se opõe uma identidade negra politicamente manifesta, a complexidade deste sistema deve-se não somente a desenvolvimentos recentes, como também à história das relações.

Desde a época colonial, as relações raciais, como também as outras relações de poder, parecem ter sido caracterizadas pela relativa ineficácia de regras universais com respeito aos direitos de cidadania (Viotti da Costa, 1985) e, do ponto de vista dos negros e mestiços, pela preferência de soluções individuais para fazer frente à opressão racial, combinada com momentos de resistência silenciosa e, por vezes, de rebelião. Esta situação produziu no Brasil, de forma semelhante aos outros países da variante ibérica do colonialismo (Hoetink, 1967), um sistema racial não polar, caracterizado por um alto grau de miscigenação; uma tradição sincrética no campo da religião e cultura popular; um continuum de cor e uma norma somática hegemônica que têm historicamente colocado os fenótipos negros na escala inferior da noção de "boa aparência". Em torno deste sistema, como produto das tradição das relações raciais, tem-se constituído um conjunto de de habitus racial.

No Brasil, este sistema reflete o conflito e a negociação ao redor da cor e, mais amplamente, as várias formas como a ideologia racial é vivenciada nas diferentes camadas sociais e nas instituições. Ele reflete os discursos oficiais - do Estado, da Igreja Católica, dos políticos - e, em época recente, os discursos da indústria do lazer, do turismo, da propaganda, da mídia e das ciências sociais sobre as relações raciais. O desenvolvimento da identidade negra também influencia este sistema racial. Tudo isso produz um sistema absolutamente não estático, com regras sujeitas a mudanças, onde o conflito de interesses fortalece um certo ecletismo e as "normas somáticas" (o tipo físico e a "aparência" preferidos) são menos estáticas do que normalmente assumido.

O que aqui pretendo salientar é como o habitus está descrito na obra de Gilberto Freyre: Casa-Grande \& Senzala (C\&S), uma primeira e monumental tentativa de traçar as origens das relações raciais brasileiras dentro da sociologia das relações sociais na sociedade escravocrata. Dando prosseguimento, procuro distinguir discurso luso-tropicalis- 
ta - com seus momentos lusófilos - e etnografia. Em seguida, baseado em minha própria pesquisa em Salvador e em sua região metropolitana, passo a analisar quanto do quadro dado por C\&S é ainda reconhecível no cotidiano das relações raciais de hoje e que aspectos deste quadro, por sua vez, vêm mudando por efeito da modernização da sociedade brasileira e, mais ainda, em conseqüência do processo de globalização das culturas e das identidades (negras).

\section{O HABITUS RACIAL EM CASA-GRANDE E SENZALA}

O Brasil de Freyre é aquele do Nordeste açucareiro e escravocrata. As relações raciais desenvolviam-se então num contexto onde a economia da escravidão baseia-se em relações de status (mais do que de "contrato"), altamente hierárquicas e repletas de procura de respeito e de re-afirmação da subalternidade dos escravos e, muitas vezes, dos não brancos em geral. É uma escravidão que Freyre apresenta não somente como pré-industrial, mas também como um grande exemplo de despotismo oriental implantado no Novo Mundo.

Freyre não poupa críticas irônicas a aspectos do comportamento e da personalidade dos senhores: a moleza e a preguiça feitas arte, a tendência para o deboche sexual e culinário, a perversidade, a violência, a crueldade inútil e substancialmente sádica para com os escravos. Mas talvez a coisa que mais o irritou foi a conclusão de que os senhores falharam, sobretudo, na própria tarefa de patriarca: não conseguiram dar o bom exemplo, nem em termos de comportamento correto nem em termos de postura perante o trabalho. E quando o patriarca falha, as pessoas a ele sujeitas assumem parte destas falhas. Assim, por exemplo, a ética do trabalho e a postura perante os luxos dos senhores influenciaram profundamente os gostos e comportamentos dos escravos.

Mas há outros aspectos deste caldeirão da brasilidade e da nova "raça" brasileira que é o conjunto da casa-grande e da senzala na obra de Freyre que ele, de forma mais ou menos explícita, elogia, nele identificando o núcleo da futura personalidade brasileira - elástica, plástica, adaptável ao meio ambiente a às circunstâncias socioeconômicas, bem como ambígua - que constitui o tipo "luso-tropical". Neste trabalho enfoco sobretudo os aspectos mais diretamente relacionados às relações raciais e que levam à criação do habitus racial.

Em primeiro lugar, há uma grande hibridez tanto na composição fenotípica de um crescente número de brasileiros quanto na cultura que os acompanha. O Brasil de Freyre seria definido hoje por muitos pesquisadores do mundo caribenho como um país creóleou seja, "algo que vem do Velho Mundo, mas cresce no Novo Mundo" (Mintz \& Price, 1985:6) -, uma sociedade caracterizada pela miscigenação e pelo sincretismo, apta a englobar e a transformar símbolos e influências que provêm de outros lugares.

Outros importantes aspectos dizem respeito à relativa permeabilidade e relatividade das categorias raciais, que podem ser contornadas e iludidas por meio do uso de outras caraterísticas e qualidades de forma a ajudar a superar as barreiras de raça. Assim, simpatia, inteligência, riqueza e beleza podem ser utilizadas com astúcia pelos negros para adquirir, digamos diagonalmente, o que eles sabem não poder obter de forma mais direta. Esta forma direta implicaria num conflito ę num enfrentamento polarizante entre os diferentes grupos de cor, algo que, pelos motivos mencionados a seguir, tanto brancos quanto não brancos tentam não deixar ocorrer. 
O funcionamento da sociedade escravocrata de tipo patriarcal tende, efetivamente, a favorecer o desenvolvimento de laços que unem senhores, homens livres e escravos numa rede de trocas desiguais, que pode levar à forma material do paternalismo - o apadrinhamento. O objeto desta troca entre partidos com diferentes poderes e status pode ser tanto o sexo como o respeito, ambos trocados (ou comprados) por favores.

Não obstante, a subalternidade e a desigualdade embutidas neste tipo de troca levariam a uma certa intimidade entre pessoas de diferentes grupos sócio-raciais. Neste contexto, a cordialidade, mais do que a alma das relações sociais entre brasileiros, têm funções - o óleo que permite ao mecanismo funcionar, um código de comportamento, a etiqueta que permite aos indivíduos se movimentaram com habilidade dentro do sistema de relações raciais.

Um último ponto importante nesta listagem de caraterísticas das relações raciais à brasileira descritas por Freyre é que os diferentes partidos no sistema de relações raciais tendem a ter sonhos e expectativas comuns com relação a alguns aspectos, como as posturas perante trabalho, luxo, lazer e Deus. Como resultado, os negros brasileiros vivem muito menos em esferas separadas, com valores e códigos próprios, e têm conseguido seduzir mais os brancos do que os negros norte-americanos. Para Freyre, como mais tarde para Jorge Amado e muitos outros, na realidade a cultura negra ou afro-brasileira, mais do que como uma (sub)cultura de resistência, pode ser vista como a espinha dorsal da cultura brasileira, com as "maneiras" dos negros figurando como um componente essencial do "ser brasileiro".

Gostaria de destacar em particular duas interessantes contribuições tanto do discurso quanto da etnografia de C\&S. Por um lado, a ênfase na coexistência de diferentes estratégias utilizadas pelos oprimidos no seu relacionamento com os opressores, num contínuo que vai da resistência à negociação e à sedução [uma ênfase que se percebe mais tarde nos trabalhos de Genovese nos E.U.A. (Genovese, 1972) e, aqui no Brasil, nos de João Reis e outros (Reis \& Silva, 1989)]. Por outro, Freyre salienta a existência de um quadro no qual a hegemonia cultural nem sempre se dá, devido ao fascínio recíproco, mesmo que mutável, entre opressor e oprimido, que deve ser reconquistado no dia-a-dia.

Em suma, o fato do habitus racial ter tido sua própria origem num tipo de escravidão dura e altamente exploradora - mas também paternalista e pré-moderna, no sentido da economia capitalista, em lugar de um tipo de escravidão mais racional e racionalizante, aludindo, na maioria dos casos implícitas, à sociedade norte-americana - significa para Freyre que no Brasil chega-se a regras bem específicas no jogo das relações raciais. Sem esta constante comparação com uma grande sociedade escravocrata do hemisfério norte, muitas das observações de $\mathrm{C} \& \mathrm{~S}$ não teriam sentido (Benzaquen de Araújo, 1994:97-98). O específico brasileiro nas relações raciais, seja na obra de Freyre ou na de outros autores, somente emerge de forma contrastante e relacional. Como poderia ser de outra maneira? Existe hibridez no Brasil, é a tese, porque em outra terra há nitidez e linhas bem demarcadas.

A linguagem de Freyre, como também sua tenacidade em fazer da apresentação da enorme quantidade de detalhes etnográficos instrumento de um discurso - a ponto de alguns críticos definirem sua história social do patriarcado escravocrata como uma saga (Lemaire, 1989) - são, sem dúvida, elementos que têm enormemente colaborado para a perda de atualidade de sua obra. Não obstante todos os pontos mencionados acima, 
uma parte do quadro das relações raciais fornecido por Freyre e a apresentação de alguns dos dilemas embutidos nestas relações continuam atuais. Isso é o que procuro explicar a seguir.

\section{O HABITUS RACIAL CONTEMPORÂNEO}

Quais aspectos do quadro das relações raciais em C\&S são constatáveis hoje num Brasil que, ainda que não plenamente, é governado por relações ditadas pelo "contrato" mais do que pelo status?

As relações raciais no Brasil passaram, depois dos anos trinta, por mais duas fases, uma que eu denominaria como de modernização e outra de globalização. A primeira corresponde ao crescimento econômico, abarca a ditadura e depois o processo de democratização; a segunda está associada tanto à consolidação da democratização e à revolução educacional que leva a um crescimento generalizado do nível escolar e das expectativas em termos de emprego, quanto à duradoura crise econômica e ocupacional.

Minha pesquisa está sendo desenvolvida no contexto desta última fase. Seu título é "Cor, Classe e Modernidade" e tem sido realizada em duas áreas da Região Metropolitana de Salvador (Sansone, 1992, 1993). Abrange a classe baixa e média-baixa - ou seja, não inclui a nova casa-grande, os senhores e a elite - e enfoca os discursos e as práticas através das quais a maioria do povo negro-mestiço vivencia as relações raciais no cotidiano. Trata, ademais, do processo de criação de uma nova identidade negra e de como tem mudado a terminologia da cor nas novas gerações.

Como funcionam as relações raciais nas áreas que tenho pesquisado? Um dos principais achados é aquele que sugere as relações raciais como que compostas por fatias. A partir das falas dos entrevistados, delineia-se um quadro no qual a cor é vista como importante no orientar as relações de poder e sociais em algumas áreas e momentos (áreas "duras"), enquanto é desproblematizada em outras (áreas "moles"). Nas áreas "moles" as distinções são vistas sobretudo como ligadas à classe, idade, sexo e bairro. As áreas "duras" pela relações de cor são: (1) o trabalho e a procura do trabalho em particular; (2) o mercado matrimonial e da paquera e (3) os contatos com a polícia. ${ }^{1}$ A primeira é aquela indicada pelo maior número de pessoas; a segunda abrange a criação do gosto e da noção de beleza em geral, bem como no âmbito específico das aulas, turmas, famílias e rua; a terceira interessa exclusivamente a uma parte dos homens, em particular aqueles com um estilo de vida "arruaceiro". Já as áreas "moles" são todos aqueles espaços no qual ser negro não dificulta e pode às vezes até dar prestígio. Abrange o domínio do lazer, em particular o botequim, o dominó, o baba, o bate-papo com os vizinhos na esquina, o sambão, o carnaval, o São João (as quadrilhas, o forró, as visitas aos vizinhos), a torcida, a seresta e naturalmente a própria turma - grupo de "iguais" com os quais se

Carlos Hasenbalg (neste volume) sugere que a escola é também um componente da "área dura" das relações raciais. Eu tendo a considerar o mundo da escola como um espaço intermédio já que, normalmente, é percebido pelos jovens negro-mestiços como um espaço que corresponde a um momento de vida mais livre, mais permeável pelos símbolos da cultura negro-juvenil baiana e menos discriminante do que o mundo do trabalho. 
compartilha uma boa parte do lazer em público. Há também a Igreja Católica, as crentes e os círculos espíritas. Estes podem ser considerados espaços negros implícitos, lugares nos quais ser negro não deveria ser um obstáculo. Há também os espaços negros mais definidos e explícitos, os lugares nos quais ser negro pode ser uma vantagem: o bloco afro, a batucada, o terreiro de candomblé e a capoeira. Estes são freqüentemente denominados com o termo abrangente de "cultura negra". Nestes espaços implícitos geralmente evita-se falar em termos de cor e menos ainda de racismo; o importante é ser cordial e se dar bem com todas as pessoas compartilhando o mesmo contexto. Os espaços explícitos funcionam ao redor daquelas atividades consideradas como típicas da "raça" (negra), nas quais desde sempre o negro pode e deve brilhar. São os momentos nos quais uma parte importante dos negros - sobretudo os de classe baixa - mais se sentem à vontade, capazes de manifestar abertamente caraterísticas das suas próprias personalidades e criações culturais que em outros momentos seriam consideradas fora de lugar. Nestes espaços é o negro que manda e são os não negros que devem negociar a própria participação com os negros, que detêm a posição hegemônica. A presença desta hierarquização de domínios e espaços em relação à importância da cor - percebida através de entrevistas conduzidas com pessoas de diferentes cores - cria um continuum: na procura de trabalho há o máximo de racismo; nos espaços negros explícitos, o mínimo.

Neste âmbito, o uso de terminologia da cor, como também as estratégias para gerir as relações raciais, varia por contexto (trabalho, lazer, família) ou momento do dia ou da semana, como também em relação ao tipo de conversa, e de quem e com quem se fala (Sansone, no prelo).

Assim, a cada âmbito da vida privada parecem estar associados alguns termos de cor e uma particular preocupação com a norma somática, seja na família ("eu sou mais ou menos escuro do que o meu irmão"; "puxei pela parte branca/negra da família"), na turma (negão), numa briga ou insulto ("coisa de preto"), no carnaval ou no universo da música e da religião (a "cultura negra", o baiano e a baiana) ou no namoro (neguinho e neguinha).

O lugar no qual se fala é também importante. A própria rua e a vizinhança são vistos geralmente como espaços liminares nos quais é preciso mediar menos com os códigos "brancos". Esta liminaridade é constituída em oposição ao mundo de fora, sobretudo a "cidade alta", onde estão localizados os mais ricos. Esta é a "pätria" dos termos de compromisso, como moreno e escuro, com os quais se contorna as diferenças raciais e, substancialmente, nega-se a polaridade branco-negro.

O uso dos termos da cor varia também com relação ao horário e dia da semana. Durante o dia, quando se encara o mundo de fora, "na luta" ou "correndo atrás do trabalho", a tendência é minimizar as diferenças de cor, apelando-se ao universalismo que deveria governar as regras do contrato social e, se necessário, utilizando os termos tidos como oficiais, sobretudo moreno, escuro e pardo. De noite e nos finais de semana, quando o assunto é descansar ou curtir, os termos da cor podem ser utilizados com mais liberdade, expressando amizade ("meu preto"' ou "brancão") ou com veemência ("seu preto" ou "branquelo"').

O status, o grau de proximidade e a ausência ou presença da outra pessoa no momento da fala são três outros importantes fatores. Uma mesma pessoa pode ser chamada de moreno ou negão caso esteja presente ou se "tiver moral" no pedaço (ou seja, é respeitado), assim como de escuro em sua ausência ou até escurinho, se o intuito for enfati- 
zar seu baixo status. Assim, é mais frequiente o uso do termo escurinho para um servente de pedreiro do que para um profissional liberal. As relações de amizade, assim como o medo da fofoca, podem levar a classificar uma família vizinha por meio de termos tido como positivos, quais sejam, moreno em lugar de preto, ou mista ou misturada em lugar de exclusivamente branca ou negra.

A maneira do indivíduo se mover dentro destes âmbitos e momentos muda por faixa de idade, de educação e de renda, como também pelo seu caráter individual e pelas contingências específicas de cada caso.

Para a complexidade das relações raciais por mim pesquisadas na Bahia contribui o fato destas, longe de se constituirem em um universo estável, estarem mudando em alguns aspectos. Fatores importantes de mudança, sobretudo ligados a crescentes diferenças geracionais e ao surgimento de uma nova identidade negra entre uma parte dos jovens negro-mestiços, são, evidentemente, a internacionalização e globalização de uma série de símbolos associados com a cultura negra. Isto acontece por efeito da atuação da mídia e da indústria cultural, assim como, de forma crescente, em decorrência do trabatho de organizações não-governamentais, igrejas, grupos de militantes e intelectuais negros e não negros.

É necessário salientar que alguns aspectos das relações raciais no Brasil, em particular os que dizem respeito à posição do negro na sociedade, sempre foram relativamente internacionais, no sentido de serem parecidos com a situação do negro em outros países do Novo Mundo. A sobre-representação dos negros entre os pobres e os "marginais" (the underserving poor) e as práticas de auto-exclusão de certo tipo de trabalho ou espaço na cidade (seja porque percebidos como negrófobos pelos próprios negros), são impressionantemente parecidos, mesmo quando comparando países com sistemas raciais bem diferentes, como aqueles que pertencem à variante Ibérica ou protestante das relações raciais (Hoetink, 1967). Somente um olhar cego influenciado pela retórica luso-tropicalista pode deixar de notar estas similitudes transnacionais. São mais suscetíveis de globalização alguns aspectos das relações raciais, em particular aqueles mais associados com as práticas culturais e o lazer, como o gosto musical (refiro-me a influência de reggae, merengue e soul/hip hop, respectivamente no samba-reggae, na lambada e no funk), o uso do visual negro (desenvolvimento de novas estéticas negras) e o universo das idéias e dos ideais [aquele conjunto que Arjun Appadurai (1990) chama de ideoscape]. Penso, neste caso, em slogans como "negro é bonito", affirmative action, empowerment, "reparação", assim como a "reafricanização", dentro do sistema religioso afrobrasileiro e, mais em geral, a procura de essencialismo por parte do movimento negro. Outro importante conjunto de ideais que tende a globalizar diz respeito às expectativas de vida, em termos de consumo e de cidadania, por exemplo.

Outros aspectos das relações raciais detectados na minha pesquisa estão ligados mais especificamente à chamada variante ibérica e tendem a estar mais tenazmente atrelados a circunstâncias locais. Por exemplo, embora existam as diferenças anteriormente mencionadas na forma de perceber as relações raciais e de encarar o racismo, algo que pode ser feito mais ou menos explicitamente pela grande maioria dos informantes, parece existir consenso ao redor das regras gerais do jogo nas relações raciais. Sobre estes aspectos, que definiria como "locais", trato a seguir.

Mesmo diante de uma forte e crescente mestiçagem, revelada também no constante aumento no número de "pardos" segundo dados do Censo, persiste o racismo, mesmo 
que na maioria das vezes de forma mais sutil do que há uma geração, e, entre os mais pobres, a preferência somática pelo tipo caucasóide claro, numa postura que chamaria de "xuxofilia"' (Simson, 1994).

Embora a grande maioria declare que o homem/mulher ideal é moreno, de forma geral quanto mais traços negróides uma pessoa tiver, quanto mais, segundo esta ideologia racial, tal pessoa deverá tentar compensar a conotação negativa destes traços. Tal compensação poderá se dar através de outras qualidades, como elegância, corpo escultural, cortesia, simpatia, bondade, bom papo, símbolos de status etc. Quer dizer, em geral, na paquera uma menina branca deve se esforçar menos do que uma menina negra.

Esta preferência por traços caucasóides claros, incluindo olhos azuis e cabelo liso, coexiste com um discurso sobre a cor articulado em três pontos. Primeiro, pelo menos na própria rua não existe - ou não deveria existir - preconceito de cor "porque gente pobre não tem preconceito e é solidária'. Segundo, na rua há “'gente boa e gente ruim', e não pessoas de cor diferente. Terceiro, ninguém se pode permitir não gostar de negros na Bahia. Segundo este último discurso, a mistura de cor é tão grande que na Bahia já não há brancos: "todo o mundo tem um pé na cozinha" e mesmo os brancos têm sempre um negro na família; os brancos "legítimos" vêm de fora.

A presença da cor na linguagem cotidiana é muito forte, mesmo se, por vezes, de forma indireta. O uso de termos referentes à cor é cauteloso, mas parecem existir poucos tabus em seu emprego. Pode acontecer que se fale mal de um preto dentro de sua própria família e até em sua presença. De fato, nota-se a coexistência de proximidade e antagonismo no mesmo espaço: negros e não negros compartilham, até com genuína cordialidade, muitos espaços no bairro, mas isso não exclui a recorrência de tensões ao redor da cor. Estas tensões não alcançam quase nunca a forma de protesto explícito ou briga, porque existe embutido nas pessoas, negras ou não, uma atitude que previne a escalada da tensão, qual seja, a consciência de que polarizar na base da cor "não leva a nada" e que as pessoas de baixa renda de um mesmo bairro devem "se dar bem e se ajudar", ou seja, ser solidárias umas com as outras. É como se nestes momentos se afirmasse uma sutil e pouco politizada consciência de classe.

Na própria rua - no "pedaço" - os moradores procuram e mantêm momentos de confraternização, em particular naquelas situações percebidas como liminares ou anti-estruturais: o lazer na praia, o botequim, a conversa na própria turma, as festas de aniversário. O valor de cada um destes espaços fica na possibilidade de oferecer não somente aconchego e igualdade, mas também variedade. Um botequim visitado somente por um tipo social e/ou racial de moradores é destinado, no curso do tempo, ao fracasso. Da mesma forma, o status de uma festa de aniversário onde compareçam somente negros é baixo. Um dos motivos pelos quais os moradores apreciam este tipo de variedade é que nestas ocasiões são tecidas as redes, menos forte do que uma geração atrás, do apadrinhamento e da procura de (pequenos) favores em troca de serviço e prestígio. É evidente que esta confraternização é interpretada de formas diferentes pelas partes; não obstante, quem procura favores (geralmente os mais escuros) e quem os oferece (geralmente os mais claros) concordam na necessidade de alimentá-la.

A cordialidade é a linguagem das relações raciais entre pobres e entre eles e os mais ricos. Ao mesmo tempo que representa uma estratégia alternativa à polarização racial e ao uso político-coletivo da identidade negra, é instrumental à articulação de soluções individuais. 
Para neutralizar ou "driblar" os possíveis obstáculos apresentados pelo fenótipo negro no cotidiano, os informantes com traços mais negróides desenvolvem estratégias individuais e, em medida muito menor, lançam mão de estratégias coletivas. A força das estratégias individuais e a fraqueza das coletivas relacionam-se com o sistema de classificação da cor - que oferece possibilidades individuais para os negros adquirirem um certo respeito entre não negros - e com a situação política brasileira-baiana, caracterizada pelo desencanto político, a ambigüidade e a negociabilidade do apoio político e do voto. O desenvolvimento de qualidades compensatórias como vestir-se "certinho", simpatia, cordialidade ou brilhar na própria profissão - aquele jogo de cintura que permite conviver com o preconceito - tem a grande vantagem de oferecer muitas variações e de ser conhecida ou previamente experimentada. Estas estratégias individuais podem ser consideradas a versão moderna daquele "jeitinho negro" criado para resistir no dia-a-dia aos escravistas brancos ou para negociar com eles uma vida melhor ante uma posição de poder desfavorável (Reis \& Silva, 1989). Ser hiperelegante, bom músico ou bom falador sempre foram maneiras de seduzir, iludir ou até mesmo enganar quem tinha em princípio o domínio absoluto sobre a vida e/ou corpo do negro, como também foram maneiras de adquirir status e dignidade (Genovese, 1972). Como em muitos outros aspectos da vida, nas relações de cor as soluções individuais parecem mais fáceis e as pessoas acreditam que o jeitinho individual é o método mais eficaz. No fundo, uma parte dos negros prefere um sistema de relação de cor confuso e não polarizado, como aquele detectado nas duas áreas. Por um lado, isto decorre do fato de que eles não acreditam que o problema da cor tenha solução. Por outro, através da manipulação ou alteração dos próprios atributos físicos (alisando os cabelos, por exemplo), conseguem deslocar e redefinir a própria posição tos ou como "pessoa legal".

$\mathrm{Na}$ maioria das falas a postura perante raça e muitos aspectos do gosto (o gosto musical ou o carnavalesco, por exemplo) premia a "mistura" mais que a pureza (penso na popularidade de termos como samba-reggae, axé music, música breganeja ou sambaneja) (Da Matta, 1984:35-48). O sucesso tanto de um tipo de beleza quanto de um estilo ou das letras de uma música depende sobretudo do fato de serem percebidos como capazes de englobar componentes e origens diversos. Originalidade, ainda que seja uma categoria extremamente relativa ao contexto, não representa o fator mais importante nesta da cor, também podem mudar segundo o contexto: os tipos físicos ou de música preferido "sensual", do "moreno", do "tempero" e até do "nia. À noite há mais aceitação apolíneo, tendendo ao "branco".

Neste sentido, a mestiçagem, além de fenômeno biológico, pode também ser considerada um estilo de vida e uma maneira de pensar o mundo, envolvendo cordialidade, produzindo momentos de confraternização e criando discursos na direção do mito da democracia racial. A força deste mito reside nas suas múltiplas e diferentes interpretações - cultas e vulgares, negrófobas e universalistas (Wade, 1993; Sansone, 1995a) -, a grande maioria das quais articulando uma linguagem própria na qual o termo "democracia racial" não se faz presente. Termos utilizados com freqüência incluem baianidade, "tempero e mistura de cor", ou aqueles relativos ao culto da morenidade, presentes, por exemplo, nas letras da música axé, de pagode e nas convocatórias de alguns blocos de trio elétrico. 
Se a democracia racial é um mito - como sem dúvida o é - trata-se de um mito fundador das relações sócio-raciais, que se inspirou, nas suas origens, na "fábula da mistura mágica das três raças: a branca, a negra e a índia', (Da Matta, 1982). Tal mito é aceito por uma grande parte do povo, que o reproduz no próprio cotidiano, articulando-o numa série de discursos populares a respeito das relações raciais. Nestes discursos, como sugerido também pela pesquisa de Sheriff (1994), a democracia racial, mais do que ser associada à situação da sociedade de hoje, é transformada num valor, num marco de um sonho de uma sociedade melhor, mais justa e menos discriminatória, na qual todo mundo "é gente'". Por meio deste sonho tenaz e popular, a sedução universalista atinge as camadas populares, demonstrando que existe uma certa troca entre os discursos raciais das elites e os da massa dos negro-mestiços (Viana, 1995; Ribeiro, 1995). Inspirando discursos, sonhos e, às vezes, práticas, o mito da democracia racial tem um componente de realidade, não podendo ser simplesmente apagado da análise antropológica como se fosse um disfarce imposto para mascarar uma realidade de racismo. Em alguns âmbitos, como a família e o lazer, este mito popular coexiste também com a relativização da cor nas práticas sociais, com momentos de intimidade extra-racial e com a produção de estratégias individuais de gerir o aspecto físico negro na vida cotidiana.

\section{CONCLUSÕES}

São estes aspectos que defini como mais tenazmente locais que mais nos lembram, em alguns momentos, o quadro das relações raciais descrito em Casa-Grande \& Senzala. Não são poucos os pontos nas situações esboçadas neste trabalho que podem ser associados a categorias freyreanas, como hibridez, plasticidade e adaptabilidade. Como nas descrições em C\&S, encontra-se nas áreas pesquisadas uma mistura de racismo, forte e criativa cultura negra e uma identidade negra que é politicamente fraca e nem sempre antagônica.

Estes são aspectos freqüentemente descuidados pelo olhar "lusófobo" daqueles pesquisadores - penso sobretudo em Skidmore (Skidmore, 1994), cuja maior preocupação parece ser a crítica da "ambigüidade" das relações raciais à brasileira -, que parecem fascinados por uma hipotética polarização racial no Brasil. ${ }^{2}$ Não procurar entender o funcionamento destes segredos baianos no que tange às relações raciais, em particular os aspectos mais especificamente ligados às realidades soteropolitana, brasileira e até latino-americana, pode significar descrever os negros brasileiros como uma massa de "não assumidos" (o que, hoje, quase equivale a estúpidos) e as relações raciais como farsa ambígua e hipócrita.

2 A forte convicção de que um sistema racial bipolar, como aquele nos E.U.A., favorece a emancipação do negro, por estimular a formação de um lobby negro e, mesmo dentro de um contexto racialmente segregado, de uma classe média e de uma liderança negra, já estava presente no pensamento de Talcott Parsons. Para este autor, a ideologia calvinista produz instrumentos para a participação de diferentes grupos subalternos no jogo democrático moderno, muito mais do que o pensamento católico (Parsons, 1968). Esta postura, e a tendência a considerar o sistema racial dos países da variante ibérica da colonização como mais "atrasado" e "ambíguo", encontra-se também em dois recentes trabalhos de envergadura comparativa sobre as relações raciais no Brasil e nos Estados Unidos (Winant 1994; Hanchard 1994). 
Evidentemente, hoje não se pode abordar o estudo das relações raciais na Bahia urbana unicamente com base nas categorias freyrianas - o culturalismo, o provincianismo e a tendência à elegia no uso destas categorias têm contribuído para torná-las obsoletas. Ademais, hoje é menos do que nunca possível reconduzir as relações raciais a uma unicidade de origem e de tipo de comportamento, como foi feito em C\&S. A tendência é rumo a uma pluralidade crescente de discursos e práticas raciais, nas quais cordialidade e novos sincretismos podem se desenvolver ao lado de um aumento da conflitualidade na identidade negra e do processo de de-sincretização do universo simbólico afro-brasileiro. Por exemplo, hoje a redescoberta das raízes pode tomar rotas que cruzam o oceano diversas vezes em várias direções. ${ }^{3}$

O cuidado pelos aspectos internacionais e pelo processo de globalização da identidade negra (e do racismo) não deve significar a diminuição da curiosidade pelo segredos no jogo das relações raciais no Brasil. As relações raciais têm experimentado mudanças e desprovincialização, mas não de forma unívoca na direção de uma maior polarização como nos E.U.A. Cor, pobreza e discriminação racial não combinam da mesma forma em todos os países. Por exemplo, na Bahia esta tríade nem sempre conduz a tornar-se ne-
gro assumido.

Diria que a herança mais importante de Casa-Grande \& Senzala, no que tange ao estudo das relações raciais, é a importância do habitus racial. Este define a forma pela qual o símbolos internacionais e internacionalizantes são reinterpretados e combinados com os próprios símbolos mais locais.

\section{REFERÊNCIAS BIBLIOGRÁFICAS}

APPADURAI, A., 1990. Disjuncture and difference in the global cultural economy. In: Global Culture. Nationalism, Globalisation and Modernity. A Theory and Society Special Issue
(M. Featherstone, ed.), pp. 295-310. London: Sage.

BENZAQUEN DE ARAÚJO, R., 1994. Guerra e Paz. Casa-Grande \& Senzala e a obra de Gilberto Freyre. Rio de Janeiro: Editora 34.

DA MATTA, R., 1982. Relativizando. Petrópolis: Vozes.

DA MATTA, R., 1984. O que Faz o Brasil, Brasil? Rio de Janeiro: Rocco.

GENOVESE, E., 1972. Roll, Jordan, Roll. The World the Slaves Made. New York: Pantheon.

HANCHARD, M., 1994. Orpheus and Power. The Movimento Negro of Rio de Janeiro and

São Paulo, Brazil, 1945-1988. Princeton: Princeton University Press. HOETINK, H., 1967. Caribbean Race Relations. A Study of Two Variants. New York: Ox-
ford University Press.

LEMAIRE, R., 1988. Freyre' Masters and the Slave as a saga. Unpublished manuscript. Amsterdam: Faculteit der Letteren, University of Amsterdam.

Sobre a relação entre globalização e cultura negra, tanto na Europa como no Brasil, vide Sansone (1994,
1995b). 
MINTZ, S. \& PRYCE, S., 1985. "Introduction”. In: Caribbean Contours (Mintz, S. \& S. Pryce, eds.). Baltimore: John Hopkins University Press.

PARSONS, T., 1968. The problem of polarization on the axis of color. In: On Color and Race (J. H. Franklin, ed.). pp. 349-369. Boston: Houghton Mifflin Company.

REIS, J. \& SILVA, E., 1989. Negociação e Conflito. A Resistência Negra no Brasil Escravista. São Paulo: Companhia das Letras.

RIBEIRO, F., 1995. A sociedade plural: imersa no fluxo da nação (Brasil) ou encarcerada no país dividido (África do Sul). XIX Encontro Anual da Anpocs. Caxambu, Minas Gerais.

SANSONE, L., 1992. Cor, classe e modernidade em duas áreas da Bahia. Estudos Afro-Asiáticos, 22:143-174.

SANSONE, L., 1993. Pai preto, filho negro. Trabalho, cor e diferença de geração. Estudos Afro-Asiáticos, 25:73-98.

SANSONE, L., 1994. The making of black culture. Critique of Anthropology, 14:173-198.

SANSONE, L., 1995a. Mudar o imutável. Políticas públicas e desigualdade raciais no Brasil e em alguns outros países. XIX Encontro Anual da Anpocs. Caxambu (MG).

SANSONE, L., 1995b. O local e o global na cultura afro-baiana. Revista Brasileira de Ciências Sociais, 29:65-84.

SANSONE, L., no prelo. Nem sempre preto ou negro. O sistema de classificação racial no Brasil que muda. Afro-Ásia, Salvador.

SHERIFF, R., 1994. Woman/slave/saint: a parable of race, resistance and resignation from Rio de Janeiro. Manuscrito Inédito. Rio de Janeiro: Núcleo da Cor, IFCS, UFRJ.

SIMSON, A., 1994. Xuxa: Megamarketing do Sexo, da Raça e da Modernidade. São Paulo: Sumaré.

SKIDMORE, T., 1994. O Brasil Visto de Fora. São Paulo: Paz e Terra.

VIANA, H., 1995. O Mistério do Samba. Rio de Janeiro: Zahar.

VIOTTI DA COSTA, E., 1985. The Brazilian Empire. Myths and Histories. Chicago: Chicago University Press.

WADE, P., 1993. Blackness and Racial Mixture. The Dynamics of Racial Identity in Colombia. Londres: The John Hopkins University Press.

WINANT, H., 1994. Racial Conditions. Minneapolis: University of Minnesota Press. 


\section{O NEGRO COMO LUGAR \\ Joel Rufino dos Santos}

\section{INTRODUÇÃO}

Parece, hoje, indiscutível, à luz da ciência, que no caso dos seres humanos não há raças. Em apenas um sentido, que Lévi-Strauss chamou "raças invisíveis", a antiqüíssima palavra quer dizer alguma coisa quando se refere a nossa espécie - são os conjuntos de freqüências genéticas que fazem, ocasionalmente, uma pessoa loiríssima estar mais perto de outra preta retinta do que de outra também loira.

Não há raças e entretanto há relações raciais. Paradoxo? Não. Na realidade, a expressão "relações raciais" acoberta outras relações, corresponde a um eufemismo. Racismo pode ser definido então como a imposição de relações de dominação disfarçadas sob a crença de que são raciais, isto é, de que há raças.

Até aqui nenhum problema. Ocorre, porém, que os oponentes do racismo, a começar, no Brasil, pelos movimentos negros, valem-se do conceito de raça e, por vezes, na sua versão oitocentista. São racialistas anti-racistas. Falam em nome da raça negra e aos atributos negativos que o preconceito afirma serem dos negros contrapõem os seus atributos positivos. A luta organizada contra o racismo - pois disso se trata - justificaria o uso de um conceito cientificamente superado? Boa ciência é aquela que serve aos homens na luta pela justiça social?

Esse é o primeiro problema: Ciência e Política. Há, contudo, um segundo: no âmbito da Política, o racialismo não tem feito avançar a luta organizada contra o racismo. Pelo contrário, ele conduziu os movimentos negros a um beco sem saída. $O$ item raça não saiu apenas do censo, saiu do jogo político e já nenhum círculo de poder se deixa impressionar pelas denúncias de racismo em si mesma.

Freqüentemente, lideranças de movimento negro são acusadas de "racismo às avessas". A acusação tem algum fundamento uma vez que a tendência de encarar a questão étnico-racial em separado, despegada da estrutura social e das relações de poder político era, até recentemente, dominante entre aquelas lideranças. Ora, num país de incrível pauperização, marcado por insolúveis problemas sociais, a pretensão de destacar do social o que quer que seja, suscita imediatas desconfianças.

As lideranças de movimento negro vêem-se, assim, sistematicamente obrigadas a combater em duas frentes: contra o mito da democracia racial e contra o estigma de "racistas ao avesso". E o que é pior, com uma arma duvidosa recolhida no arsenal oitocentista - a idéia de raça.

Como se não bastasse têm, aquelas lideranças, de enfrentar o reducionismo do pensamento convencional de esquerda, que só esporadicamente admitem as interações raciais e étnicas. É o que explica a dificuldade, hoje amenizada, de os movimentos negros estabelecerem alianças com os agrupamentos marxistas. Aquele reducionismo, aliado à 
visão do "preconceito racial como resquício da escravidão", bem como à expectativa que o desenvolvimento econômico tende a neutralizar o fator raça/cor, se encaixa perfeitamente, aliás, no arcabouço do mito da democracia racial, comprovando-lhe a eficácia e consensualidade. A democracia racial é, basicamente, o pacto nacional, supraideológico, de não considerar a interação racial como significativa. O movimento negro como tal é a ruptura desse pacto.

Não por acaso, as alianças mais resistentes dos movimentos negros, na fase que começa com a Frente Negra, há sessenta anos, têm sido com o que se convencionou chamar de populismo - ela também uma ruptura de pacto; populismo no poder ou fora dele. É verdade que tão logo se instalou, o Estado Novo fechou a Frente Negra, como é verdade também que a vertente mais política do movimento costuma atacar duramente a manipulação das comunidades negras por chefes populistas. Foi, no entanto, sob a ditadura estado-novista que o maior número de negros, proporcionalmente, ingressou no aparelho de Estado; o Partido Trabalhista Brasileiro durante a sua primeira existência (1945-64) concentrou a maioria do voto negro urbano, oferecendo, mais que qualquer outro, legenda a candidatos negros, assumidos ou não; e, enfim, foi à sombra de um remanescente populista, Leonel Brizola, que, há poucos anos, o movimento negro - na definição lata e restrita - obteve seus maiores ganhos (Soares, 1984).

Temos, pois, um impasse, a saber: a categorização do negro como raça condena a luta organizada contra o racismo à ineficácia; e uma pista para escapar dele, a saber: a aliança do movimento negro com o populismo pode instituir os parâmetros para uma recategorização do negro.

\section{POPULISMO REVISITADO}

O que se convencionou chamar de populismo - constante de medidas concretas de governo, de uma ideologia, de uma estratégia de desenvolvimento econômico-social, de uma linguagem e de uma cultura - afirmou-se entre o final do Estado Novo e o golpe militar de 1964, embora seus antecedentes venham pelo menos desde a Revolução de 30. Há certo consenso de que foi, sumariamente, a forma política assumida pela sociedade de massas no País, legitimando a entrada das massas nas estruturas de poder e funcionando como mecanismo de politização delas.

Enquanto movimento (que permeou diversos partidos políticos, governos e lideranças) o populismo apresentou, em cerca de vinte anos, quatro modalidades principais que, como esfinges desafiam a inteligência política brasileira: queremismo getulista, trabalhismo, juscelinismo e janguismo.

Até aí chega um certo consenso dos observadores. O que veio depois e como dar prosseguimento hoje ao que se costuma chamar democracia populista?

Creio haver, na atualidade, dois conjuntos principais de interpretação do nosso processo político que, embora não antagônicos, disputam a supremacia no auto-intitulado campo progressista.

Primeiro, para os intérpretes situados no interior da ordem moderna (inclusive no lugar da classe operária), o populismo nada mais foi que uma etapa na história das relações entre as classes sociais no Brasil. A liquidação da democracia populista, consumada pelo movimento militar de 64 , teria inaugurado a etapa presente de luta de classes não 
disfarçada. Essa etapa chegará também um dia aos seus limites, quando o aguçamento das suas contradições abrirá condições para a instalação da democracia socialista, potencialmente anunciada por certos elementos da etapa precedente (o intervencionismo estatal, a planificação econômica, a política de massas, certos valores culturais etc.). Essa avaliação é que serviu de teoria à geração guerrilheira que a partir de 1968 enfrentou a ditadura militar na América Latina e constitui, com um ou outro desvio, o balizamento teórico do Partido dos Trabalhadores (PT).

A segunda maneira de ver começa concordando que a democracia populista foi uma etapa vencida do desenvolvimento social e político do país, mas nega que tivéssemos passado - salvo no plano do desejo - a uma etapa subseqüente de aprofundamento da luta de classes. O que, sumariamente, teria ocorrido no Brasil após 64 e até hoje foi o aprofundamento da contradição entre ordens, ou estados: classificados (nas ordens moderna e oligárquica) versus desclassificados (ordem do povo).

Para essa segunda corrente, não se trata de negar, ingenuamente, a verdade das classes no Brasil; desde que houve aqui um padrão capitalista de acumulação (e isso houve desde a Colônia) tivemos obviamente classes. O equívoco, supõem os partidários daquela segunda maneira de ver, está em supor que classe é a forma preferencial de inserção no Brasil, no passado como no presente. Os fatos da sociedade brasileira - históricos, sociais, políticos, culturais - se organizam mais facilmente se utilizamos a categoria de inserção por ordem. Povo, por exemplo, seria uma ordem ou estado: grupo social instituído pela ausência de certos privilégios e certa maneira de estar no mundo (cultura). Estamos distante, nessa definição, do discurso político vulgar, o do hupokrisis e mesmo do sociológico comum, que dá o povo como sujeito da pobreza, e da vulgata marxista que o identifica com os produtores de bens materiais (com o que ficam de fora funcionários e intelectuais, por exemplo). (Se bem, deve-se reconhecer, é também do marxismo o conceito de povo que leva em conta o seu desenho em diferentes fases históricas e, ao mesmo tempo, os seus traços permanentes: "Em todas as situações, o povo é o conjunto das classes, camadas e grupos sociais empenhados na solução objetiva das tarefas do desenvolvimento progressista e revolucionário na área em que vive" (Sodré, 1978:191)).

A essa luz, a idéia de que constituiríamos no Brasil uma sociedade de classes é uma espetacular "idéia fora de lugar", transplantada das ciências sociais do primeiro mundo nas quais fazia perfeito sentido. "Fora de lugar", esclareça-se, não quer dizer inútil. De um lado, a teoria da luta de classes serviu para orientar, desde o começo do século, sangrentas e gloriosas lutas pela justiça social; de outro, exercendo função contrária, tem servido para recalcar o sentido profundo dessas mesmas lutas, enrijecendo mecanismos ideológicos de dominação. Está nesse caso, por exemplo, a questão racial, como sabem os que lutam organizadamente contra o racismo e vêem seus esforços reiteradamente criticados no seio da esquerda como diversionistas da luta maior, a de classes.

\section{GUERREIRO RAMOS}

Para os que se dedicam à história das idéias políticas no Brasil há um fato intrigante: por que um pensador do porte de Guerreiro Ramos, desaparecido há menos de quinze anos, está esquecido? Esquecido, advirta-se, das editoras e cursos universitários. 
A primeira explicação é que houve nos últimos quarenta anos um forte deslocamento das relações de classe entre nós e, conseqüentemente, mudou a pauta sociológica. (Outros brilhantes pensadores, como Nelson Werneck Sodré, mestre de uma geração inteira, teriam sucumbido a esse deslocamento). Há, contudo, uma explicação menos óbvia: Guerreiro foi um intelectual orgânico da democracia populista, talvez o mais original, e jaz sob montanha da modernidade triunfante (vide Maio, neste volume).

De fato, Guerreiro Ramos, como sociólogo e pensador do político, se inscreve na base da segunda maneira de ver que apontamos acima. O marxismo não passou para ele, sobretudo nos seus últimos anos de vida, de uma "idéia fora de lugar". Para usar uma expressão da moda, ele foi um pensador seminal da democracia populista. Não se pode garantir que ele estava certo, nem os outros, mas diga-se a seu favor que a democracia populista é a nossa única linhagem político-ideológica original. Ou a negamos sumariamente, como em geral costumam fazer os convictos da modernidade como caminho único, ou nos valemos dela para claborar novas estratégias de justiça social, na atualidade.

Guerreiro foi acusado, já em sua ćpoca, de negar a vertente psicológica do racismo. Eis a sua defesa:

\begin{abstract}
A partir desta situação vital / negro e o povo no Brasil são sinônimos/, o problema efetivo do negro no Brasil é essencialmente psicológico e secundariamente econômico. Explico-me: Desde que se define o negro como um ingrediente normal da população do País, como povo brasileiro, carece de significação falar do problema do negro puramente econômico. destacado do problema geral das classes desfavorecidas ou do pauperismo. O negro é povo no Brasil. (Guerreiro Ramos. 1957:157)
\end{abstract}

Portanto, ao invés de negritude, povidade. É possível que se fosse vivo hoje, Guerreiro Ramos criticasse uma espécie de "sociologia de resultados", de corte norte-americano, que se esmera sadicamente em medir o "lugar do negro no mercado de trabalho", para chegar sempre à mesma conclusão, já dada no início, de que os negros ocupam os piores lugares e são os mais mal pagos dentre os brasilciros. com a mesma veemência com que criticou a "antropologia da negritude" do seu tempo, culturalista, medrosa de enfrentar a questão das relações de poder.

Os estudos sobre o negro e a questão racial desenvolveram-se muito nos anos após sua morte (1982), mas não o bastante, suponho, para encontrar uma fórmula melhor que a sua para essa equação dupla: não há raças, mas há relações raciais; e negro é povo, mas a luta contra o racismo necessariamente depende da afirmação de negritude. Sumariamente, esta foi a sua fórmula:

Sou negro, identifico como meu o corpo em que o meu eu está inserido, atribuo à sua cor a susceptibilidade de ser valorizado esteticamente e considero a minha condição étnica como um dos suportes do meu orgulho pessoal - eis ai toda uma propedêtica sociológica, todo um ponto de partida para a elaboração de uma hermenêutica da situação do negro no Brasil. (Guerreiro Ramos, 1957:157)

Desse ponto de partida, desse lugar, eis o que ele pode enxergar:

Então, em primeiro lugar percebo a suficiência postiça do sócio-antropólogo brasileiro, quando trata do problema do negro no Brasil. Então, enxergo o que há de ultrajante na atitude de quem trata o negro como um ser que vale enquanto 'aculturado'. Então, identifico o equivoco etno-centrismo do 'branco' brasileiro ao sublinhar a presença do negro mesmo quando perfeitamente identificado com ele 
pela cultura. Então, descortino a precariedade histórica da brancura como valor. Então, converto o 'branco' brasileiro, sôfrego de identificação com o padrão estético europeu, num caso de patologia social. Então, passo a considerar o preto brasileiro. ávido de embranquecer se embaraçando com a sua própria pele. também como ser psicologiamente dividido. Então, descobre-se-me a legitimidade de elaborar uma estética social de que seja um ingrediente positivo a cor negra. Então, afigura-se-me possivel uma sociologia científica das relações étnicas. Então, compreendo que a solução do que, na sociologia brasileira, se chama o 'problema do negro', seria uma sociedade em que todos fossem brancos. Então, capacito-me para negar validade a esta solução. (Guerreiro Ramos, 1957:156-157)

Para Guerreiro Ramos, negro não é, pois, uma raça (a rigor raça não existe), mas, se fosse, a nada de progressista levaria tomá-lo como tal. Negro é uma configuração social, um lugar que pode ser ocupado mesmo por não negros (assim como o lugar do branco pode ser ocupado por um preto ou mulato). Como se descreve esse lugar?

As coordenadas para fixar o negro como lugar seriam: o fenótipo (crioulo), a condição social (pobre), o patrimônio cultural (popular), a origem histórica (ascendência africana) e identidade (autodefinição e definição pelo outro). A coordenada mais fraca é o fenótipo, uma vez que a maioria da nossa população tende para o escuro. Brasileiro é, como se deduz, o melhor sinônimo de negro; e branco um sinônimo de não brasileiro.

Estamos diante de uma radicalidade maior do que a de tomar o negro como raça discriminada em luta pelos seus direitos. Essa radicalidade consiste em apresentar o problema do negro como o problema do Brasil; e, conseqüentemente, abrir condições de inserir os seus problemas na agenda nacional. É uma radicalidade também no sentido em que produz duas críticas profundas: da crise brasileira e dos movimentos negros conforme se desenvolveram até hoje. Desse ponto de vista, desse lugar, os próprios movimentos negros são entendidos como produto da crise brasileira. a serem superados eles também dialeticamente.

\section{REFERÊNCIAS BIBLIOGRÁFICAS}

GUERREIRO RAMOS, A., 1957. Introdução Crítica à Sociologia Brasileira. Rio de Janeiro: Andes.

SOARES, G. A. D., 1984. O charme discreto do socialismo. Jornal do Brasil, junho.

SODRÉ, N. W., 1978. Introdução à Revolução Brasileira. 4a ed. São Paulo: Livraria Editora Ciências Humanas. 


\title{
14 "AQUELES A QUEM FOI NEGADA A COR DO DIA": AS CATEGORIAS COR E RAÇA NA CULTURA BRASILEIRA
}

\author{
Yvonne Maggie
}

\author{
Passamos o limite aonde chega \\ O Sol, que para o Norte e os carros guia, \\ Onde jazem os povos a quem nega \\ O filho de Clymene a cor do dia. \\ Aqui gentes estranhas lava e rega \\ Do negro Sanagá a corrente fria, \\ Onde o cabo Arsinario o nome perde, \\ Chamando-se dos nossos Cabo Verde. \\ (Os Lusiadas. Camões, 1925:canto v)
}

\section{INTRODUÇÃO}

Desde tempos imemoriais, mas sobretudo a partir da expansão colonial européia no século XVI, a cor dos povos que iam sendo encontrados pelos viajantes e exploradores tornou-se objeto do pensamento. A imaginação de escritores, poetas e daqueles que tomavam contato com essas populações cumulou-se de termos ou categorias que serviram para marcar essas diferenças. Assim, Camões em Os Lusíadas (canto v), refere-se aos africanos como "aqueles a quem o filho de Clymene " negou a cor do dia". Em outra passagem do mesmo canto o poeta diz "hum estranho...de pelle preta".

As terras novas descobertas ou o novo hemisfério perturbou a mente de poetas e gente comum, que falaram não só sobre o céu onde brilha o Cruzeiro do Sul, como sobre as características dos povos aí encontrados. De lá para cá, passando por séculos de escravização "daqueles a quem foi negada a cor do dia", essa característica física das pessoas passou a ser objeto de classificação, gerou novas formas de representação da diferença e serviu a novos mecanismos de produção da desigualdade e hierarquização.

As grandes navegações e a descoberta do Novo Mundo conduziram a representação das diferenças e a troca simbólica a níveis talvez jamais vistos anteriormente. Não só a cor das pessoas como seus modos de vida, maneiras de sentir e pensar passaram a ser objeto de reflexão e classificação tanto por parte de colonizadores quanto de colonizados. Como sabemos, as diferenças são a própria matéria do pensamento desde a passa-

Ninfa, mãe de Fetonte, Lampécia e Lampetusa. O filho de Clymene é Fetonte. 
gem da natureza à cultura, mas foi nesse encontro entre povos distantes que se levou a troca simbólica a níveis tão intensos.

Sendo a lógica das classificações o próprio objeto da Antropologia desde seu nascimento, podemos dizer que os sistemas classificatórios, a partir dos quais são decalcados significados, marcam distinções no social. O que significa que as distinções não estão contidas na natureza das coisas ou dos seres. Na natureza, tomam-se diferenças para construir, através das oposições binárias, distinções sociais fundamentais.

Cada sociedade é, assim, resultado ou marca das suas escolhas classificatórias, não havendo sociedade humana pré-lógica ou sem lógica. Todo o sistema classificatório tem sua lógica interna e cada sociedade é portanto escrava e senhora, ao mesmo tempo, do sistema classificatório que preside sua existência. A classificação não é uma essência, e o social é sempre construção.

A importância de desvendar as maneiras e os significados dados às categorias de classificação de cada grupo ou sociedade é ponto de partida para a compreensão do sistema, entendido como um todo, onde cada parte tem relação com as outras partes e com o todo.

Dito isso, proponho neste trabalho focalizar uma das muitas formas de se pensar essas diferenças que, no Brasil, parece ser um objeto predileto do pensamento.

\section{COR E RAÇA COMO MATÉRIAS DO PENSAMENTO}

A cor das pessoas, que tanto impressionou viajantes e poetas como Vasco da Gama e Camões, tem sido no Brasil um dos lados da cultura ou da sociedade escolhido para ser focalizado. No entanto, como diz o ditado, tudo se passa como se quanto mais se tivesse medo do diabo mais ele aparecesse.

Qualquer pessoa pode notar numa conversa de bar ou no vocabulário da gente comum um número excessivo de termos de cor usados na referência a terceiros, próximos ou a si mesmo. O diminutivo e a gradação de cor, de claro a escuro, enchem as frases e aquilo que é dito, encobre ou "escurece" termos para nós quase indizíveis: preto e branco.

Qual a razão ou melhor, quais as muitas formas desse resvalar por tantos termos como negrinho, pretinho, alva, alvacenta, branca de neve, pelé, em vez de se dizer simplesmente branco e preto? Como se dá, na cultura brasileira, o modo de evitar, ou "recalcar', essa diferença preto versus branco que só aparece na piada, no ato falho ou nas frias estatísticas dos censos demográficos?

Nossa sociedade funda-se em mitos que falam de raça e cor. De um lado o mito ou a fábula das três raças - no dizer de Roberto Da Matta (1980), nosso mito de origem -, que conta que viemos de três raças: negros, brancos e índios. Outro mito básico fala de nossa "democracia racial", do paraíso dos mestiços, onde o racismo e a segregação não existem. Há, finalmente, outra premissa que chamarei aqui de mito do branqueamento. $\mathrm{O}$ ideal de branqueamento fala na cor e evita a oposição preto versus branco, fundando uma sociedade povoada de claros e escuros que deve ser um dia totalmente branca, sem diferenças.

Esse mitos criam a linguagem da mistura, da indistinção no ideal de branqueamento e organizam o discurso da sociedade como um todo, afetando pessoas de todas as classes e cores. No entanto, as pessoas comuns evitam sempre oposições, preferindo as 
pontes ou as categorias que não falem na diferença preto e branco e até mesmo negro e branco, termos preferenciais dos movimentos negros e do discurso acadêmico. Os mitos estruturam uma sociedade que já teve no século passado o maior contingente populacional de pretos fora da África e que hoje tem metade da população que se autoclassifica nos censos demográficos como não branca. Seria possível pensar que essa sociedade com tantos não brancos preferisse outro caminho? Por que não marcar a diferença dos povos a quem o filho de Clymene negou a cor do dia opondo-os àqueles a quem deu a cor do dia?

Esse enorme contingente populacional de origem africana não vive uma cultura à parte, própria e autônoma. No Brasil foi construída, desde tempos coloniais, uma cultura que passou a ser chamada na literatura especializada de cultura afro-brasileira ou cultura negra, mas da qual participam tanto brancos quanto negros e cujos símbolos são marca da nacionalidade, ou seja, de todos, independentemente de sua cor ou raça.

Os termos raça e cor no Brasil têm uma história mas foram, em geral, usados para definir "os povos a quem o filho de Clymene negou a cor do dia", gente de cor, população de cor, gente da raça.

Desde a Colônia os escravos trazidos da África eram classificados com termos de cor como preto mina, preto angola etc... embora só no século XIX, ${ }^{2}$ e especialmente depois da abolição, a questão da diferença entre aqueles a quem o filho de Clymene negou a cor do dia e aqueles a quem deu a cor do dia tenha sido colocada na cor com um significado biológico. A cor do escravo definia o seu lugar social, preto e escravo eram quase sinônimos. Preto livre e pardo até mesmo no início do século, embora fossem termos de cor, decalcavam o lugar social. Os pardos eram os pretos forros. ${ }^{3}$ No período escravista o escravo era definido por sua origem africana ou crioula, da terra. A classificação de cor, preto $=$ escuro, passou a ser um problema mais contundente quando todos os escravos viraram homens livres como os brancos. Como definir a diferença então? A diferença entre as pessoas livres agora devia ser designada através da homologia entre cor e biologia. Os pretos eram diferentes porque biologicamente inferiores.

Mariza Correa (1982), analisando como essa homologia entre cor e biologia foi construída, inverte a premissa de Marx de que o escravo só eventualmente foi negro. Diz Mariza Correa que no Brasil o escravo passou a ser negro, racial e biologicamente definido, depois da abolição. Foi nesse período que o termo negro, e não preto, passou a ser usado na literatura especializada, definindo aqueles que eram biologicamente inferiores aos brancos.

Não discutirei aqui o sistema de classificação do século XIX, pois implicaria em outra problemática. O vocabulário escravista é repleto de termos que definem a origem social do escravo, um estrangeiro - angola, congo, mina, jeje ou crioulo, nascido no Brasil etc. Talvez, como diz João Reis (1986), para a Bahia a distinção mais significativa fosse localizada na diferença entre africanos e crioulos. Por isso as classificações de cor

Sobre essa discussão vide Célia Marinho (1988), que descreve a história da homologia entre cor e biologia como tendo sido iniciada no começo do século XIX. No início do século XIX a desnaturalização do escravo já cra discutida e por isso a diferença foi sendo construída cm outros termos.
}

3

Sobre essa questão, vide Castro (1995). 
ou raça, como homologia biológica, e mais encompassadoras não dessem conta dessa outra distinção mais significativa - nacionais e estrangeiros. Outra razão para as diferenças na ciassificação de cor foi dada por Lilia Schwarcz (1990). Através da análise dos jornais do século XIX verifica-se que a categoria negro começa ser mais empregada na segunda metade do século e para designar aquele escravo fora do seu lugar, o escravo fujão, rebelde.

A cor, distinção biológica que desde o final do século passado definia aqueles que eram biologicamente inferiores, e que foi discutida pelos intelectuais das primeiras décadas do século XX foi associada, mais tarde, a uma diferença e hierarquização cultural. Os pretos ou negros eram culturalmente inferiores e os antropólogos passaram muitas décadas discutindo a inferioridade cultural e não biológica desses desiguais negros e não mais escravos. Os termos cor e raça passaram a definir não só seres biologicamente inferiores como também culturas hierarquicamente concebidas. No Brasil falar em cor ou raça significa também falar em desigualdade biológica e cultural. ${ }^{4}$

No nosso mito de origem, na fábula das três raças, essas se misturaram em razão da democracia racial. Os seres diferentes biologicamente se cruzaram fazendo surgir uma gama de cores e culturas distintas e hierarquizadas.

A literatura sociológica contemporânea abandonou esse tema em favor do estudo das culturas negras, retirou de seu jargão muitos termos e premissas de nosso intrincado sistema classificatório de cor. Enquanto os estudiosos falam em carnaval e samba, candomblé e futebol como locus de culturas negras e definem todos os segmentos não brancos como negros, o discurso cotidiano das pessoas comuns é repleto de termos como claros e escuros, neguinhos e neguinhas, morenos e alvacentos.

Este sistema classificatório tem enorme vigor na linguagem cotidiana, embora geralmente ausente da discussão acadêmica. Quais os significados desse gradiente de cor? Estará ele falando também de diferenças sociológicas? Os mais claros são pensados como aqueles que têm melhores posições sociais? Os mais escuros como os que têm menos chances de vida? Em que situações essas diversas formas de classificar as pessoas pela cor são acionadas? O ideal do branqueamento ou o mito do branqueamento institui esse sistema que hierarquiza as cores?

\section{RAÇA, COR, CULTURA E SOCIEDADE}

Nossa sociedade funda-se nesses mitos que falam em raça e cor e que forjam um pensamento voltado para a natureza de nós mesmos. Somos ruins ou bons por sermos mestiços? Mas cada um dos mitos constrói um tipo de sistema classificatório e de representação da diferença. Vejamos.

A oposição negro versus branco remete à origem cultural do brasileiro, ao mito fundador da nacionalidade, pois somos fruto do encontro entre negros africanos, brancos

Raça também tem um sentido de força - a raça rubro-negra. Mas em geral e no contexto de definição de diferenças entre as pessoas significa a biologia ou a cultura do outro, daqueles a quem o filho de Clymene negou a cor do dia. 
portugueses e indígenas. Toda vez que nos referimos ao lugar cultural daqueles a quem é negada a cor do dia, falamos em negros e brancos. O "movimento negro" escolheu essa forma de definir seus participantes. Os intelectuais e toda a literatura brasileira escolheu também essa maneira de decalcar diferenças. Escolhendo esse caminho não se fala nas diferenças sociológicas, mas nas diferenças culturais entre pessoas de origens étnicas diferentes.

Uma segunda forma de se referir àqueles que não têm a cor do dia opõe brancos e pretos. Brancos e pretos diferenciam-se na estrutura da sociedade e esses termos classificam pessoas distantes, terceiros. Entre os pretos e os brancos estão os pardos e mais uma vez aparece o mito de origem que fala $\mathrm{cm}$ origens e mistura. No entanto, esses termos aparecem quase sempre como atos falhos, ou no provérbio racista, ou no xingamento. Nosso ideal de democracia racial, nosso mito de democracia racial, obriga-nos a desviar o olhar dessa oposição porque ela decalca posições sociais desiguais entre pretos e brancos. Tanto é assim que esse também é o sistema classificatório escolhido pelos que fazem os censos demográficos e as estatísticas oficiais. Pretos são os pobres, aqueles que têm menos chances de vida.

A saída do sistema e a escolha mais confortável é aquela que descreve um gradiente de cores, hierarquias que tentam desfazer tanto as oposições preto versus branco como negro versus branco, mas que contêm tanto elementos de uma quanto de outra. Claros e escuros no limite são pretos e brancos porque a classificação refere-se à luz e à ausência de luz como preto e branco. Mas claros e escuros referem-se também à cultura porque ao se referir a mais ou menos claros e mais ou menos escuros, aquele que classifica está fazendo um julgamento de valor.

Essas categorias e sistemas de classificação são como um resíduo não explicado na literatura sociológica. A ausência de reflexão sobre o sistema que preside a constituição do campo produziu um silêncio sobre o assunto. Os estudiosos tomaram, com algumas exceções, ${ }^{5}$ o dado como não significativo e a questão racial no Brasil passou a não ser referida. O silêncio sobre as desigualdades raciais e a falta de informação sobre a questão na enorme literatura sobre os "dominados", produzida desde os anos 60, é gritante. Alguns sociólogos vêm chamando a atenção sobre isso, como Carlos Hasenbalg e Nelson do Valle e Silva, que desde dos anos 70 têm produzido um conjunto de trabalhos sobre as desigualdades e a discriminação racial no Brasil (vide Hasenbalg, neste volume).

Os sistemas de classificação de cor e a discriminação e desigualdade raciais deixaram de ser pensadas como assunto relevante na litertura sociológica porque acreditou-se que não era relevante para os informantes. Alguns pesquisadores afirmavam até que a cor era ausente nas entrevistas porque as pessoas comuns não pensavam em si como pretos e brancos. Outros disseram que a questão racial era uma questão da sociologia norteamericana e, portanto, não tinha sentido no Brasil. Todos os argumentos levaram ao mesmo lugar. A questão racial, como já disse mais acima, transformou-se em questão de "cultura negra" e a produção sociológica sobre o tema encheu as prateleiras de nossas bibliotecas.

Em outro trabalho (Maggie, 1993) discuto de maneira mais detida os estudos que desde os anos 50 analisaram as formas brasileiras de classificação da cor das pessoas e os impasses produzidos. 
Mas há outra conseqüência deste silêncio que afetou tanto intelectuais como homens práticos. As relações entre brancos e não brancos e os mecanismos de reprodução dessas relações se desenvolveram sem crítica e sem lei, organizados como foram desde a abolição pelos próprios indivíduos que vivem a experiência no cotidiano. O ministério que se ocupa do assunto é o Ministério da Cultura e em 1970 o quesito cor foi retirado do censo demográfico apesar dos protestos de alguns poucos denunciadores e com o beneplácito e aquiescência de intelectuais de renome.

A retirada do quesito cor do censo de 1970 produziu muita discussão. A partir deste debate, a Pesquisa Nacional por Amostra de Domicílios (PNAD) de 1976, visando levantar dados sobre cor e mobilidade social incluiu em uma de suas sessões uma pergunta aberta sobre a cor do informante. Essa PNAD e o resultado dessa questão, por se haver chegado a 135 termos de cor, são acionados em algumas situações a favor do silêncio sobre o tema das relações raciais. No entanto, analisando mais detidamente as respostas, Nelson do Valle e Silva (1988) desvenda um universo carregado de significados que nos faz repensar nosso sistema de classificação das diferenças baseado na cor das pessoas. Volto-me a este trabalho de Nelson do Valle e Silva para discutir a questão.

\section{HIERARQUIA E OPOSIÇÃO NO SISTEMA CLASSIFICATÓRIO}

Os dados da Pesquisa Nacional por Amostra de Domicílios, levantamento anual realizado pela Fundação Instituto Brasileiro de Geografia e Estatística - FIBGE , baseiase em uma amostra de 120 mil domić́lios em todo o território nacional. Na PNAD de 1976, que cobriu uma subamostra de 1/3 dos 120 mil domicílios, foi feita uma mensuração do quesito cor para verificar a validade da medida através de duas perguntas.

A primeira, em aberto, perguntava a cor do entrevistado: "Qual a cor do senhor?". A segunda repetia a pergunta que era sempre feita nos censos para classificar a cor do entrevistado: "Entre branca, preta, amarela e parda como classificaria a cor do senhor?". A resposta deveria ser dada pelo entrevistado e o entrevistador não deveria corrigi-la mesmo que lhe parecesse estranha.

$\mathrm{Na}$ primeira pergunta foram extraídas 135 designações diferentes. Esse resultado, como disse acima, foi e ainda é tomado por muitos intelectuais e pelo senso comum como exemplo da quase impossibilidade de medir as desigualdades raciais no Brasil. $\dot{E}$ quase um consenso que essa medida é pouco eficaz porque diante de tantos termos evidencia-se um sistema de classificação racial "ambíguo".6

Insistindo em buscar a lógica de nosso sistema classificatório, Nelson do Valle e Silva (1988), analisando os resultados da PNAD-76, encontra aproximadamente $95 \%$ das respostas concentradas em apenas sete designações de cor diferentes "sendo quatro delas comuns às usadas no quesito fechado: branca, preta, amarela ou parda. As outras três categorias são as designações clara, morena clara e morena. Essa última recebendo cerca de 1/3 do total de respostas dadas' (Silva, 1988). As respostas à primeira pergunta Thomas Skidmore (1991), por exemplo, como a maior parte dos pesquisadores norte-americanos, define
nosso sistema como multirracial e ambíguo. 
revelam que os entrevistados demonstraram dúvidas quanto ao que se queria e que " a indagação na forma fechada aliviou o entrevistado, constituindo-se dessa forma na resposta mais confiável entre as duas" (Silva, 1988). O fato de as respostas abertas se concentrarem nas categorias do censo aponta para a validade e confiabilidade da "maneira pela qual os entrevistados se autoclassificavam no que tange a sua cor' (Silva, 1988). Essa miríade de termos, na verdade, espelha, na concentração das respostas, uma coincidência entre as categorias do censo e as categorias do senso comum. Ou seja, não considerando o que vem antes, se o ovo ou a galinha, o fato é que há uma coincidência entre as representações da maioria dos brasileiros e as categorias do censo a respeito da autoclassificação segundo a cor.

Nelson do Valle e Silva, nesse importantíssimo trabalho, diz que a pergunta aberta suscitou dúvida por parte dos informantes. No entanto, colocados diante das perguntas fechadas a dúvida se esvaía. Nelson do Valle e Silva, no entanto, refere-se à importância da categoria moreno que representa $1 / 3$ das respostas na pergunta aberta. Essa categoria, segundo Silva, aponta para uma ambigüidade do sistema já que conota não apenas a cor da pele como dos cabelos. No entanto, segundo este autor, essa ambigüidade não afeta a segunda pergunta, a fechada, porque o entrevistado não tem dúvida ao se classificar em uma das três opções - branco, preto e pardo. A cor amarela, como diz Silva, revela pouco sobre a origem étnica do informante, enquanto as outras três designam uma autoclassificação também de origem.

Pensarei essa questão a partir das conclusões de Nelson do Valle e Silva, voltando aos três domínios de significação que existem no nosso sistema classificatório (a oposição que revela origem - negro e branco, a dimensão que revela o lugar social - preto, pardo e branco, e o gradiente claro e escuro).

A PNAD-76 fazendo a pergunta aberta, fora de contexto, apresentou ao informante a possibilidade de fugir da oposição branco, preto, colocando um termo do gradiente - moreno - que contém tanto de cor quanto de valor cultural. O termo amarelo neste contexto da pergunta aberta não levou o informante a pensar no mito das três raças.

À pergunta aberta os entrevistados responderam com uma miríade de distinções que no limite referem-se de um lado à oposição preto e branco, já que $95 \%$ das respostas caíram nas categorias da pergunta dos censos. Brancos e pretos tendo no meio os pardos. De outro lado, os $15 \%$ restante das respostas caíram numa miríade de pequenas oposições alva/alva rosada/alva escura; bem branca/bem morena; bronze/bronze escura; café com leite/café; morena bem-chegada/morena-clara; negra/negrota; retinta/rosa que diluem as oposições preto/branco e apresentam uma valoração da cor morena bem-chegada, negrota, retinta etc...

Essa forma de descrever cores através de uma pergunta aberta e sem um contexto definido apresentou ao entrevistado a possibilidade de falar como no cotidiano, falando na cor sem falar em oposição, mas através de muitas complementariedades. Mas a concentração de $1 / 3$ das respostas na categoria moreno é instigante. Será o mulato como válvula de escape, de Degler (1971)? Essa categoria é como uma chave para se falar em cor e raça sem falar de cor e raça, pois moreno contém em si mesmo tanto cor, como ausência de cor. Tanto pode ser um negro retinto, quanto uma alva de cabelos pretos e é uma categoria que tanto revela sobre a cultura quanto pode ser usada para conotar o lugar social das pessoas. Moreno contém em si o gradiente, a oposição negro/branco e a 
oposição preto/branco. Ela é a categoria que por excelência fala do nosso modo particular cotidiano de falar nas raças e nas oposições, sem falar delas.

A concentração de $1 / 3$ das respostas na categoria morena revela ainda uma dimensão insuspeita. Charles Wood (1991), ao comparar o censo de 1950 com o de 1980, observa uma tendência na classificação racial de pessoas que se identificavam no passado como pretas, a se redefinirem como pardas posteriormente. A reclassificação de preto para pardo entre os censos de 1950 e 1980 foi de aproximadamente $38 \%$ (mais ou menos 10 pontos percentuais), e não há dados que possam dizer se os pardos se reclassificaram como brancos.

Os resultados de Wood também revelam que "uma pequena proporção da população branca pode ter se reclassificado como parda entre 1950 e 1980". Wood chama a atenção para a necessidade de se repensar a classificação de pretos e pardos em uma mesma categoria nas análises quantitativas. A mobilidade ascendente de pretos, de acordo com esses dados, seria maior que a de pardos e, assim, a junção dos dois em uma mesma categoria poderia estar sujeita a erro. Wood afirma, como Silva, que as categorias do censo são boas e adequadas para medir as desigualdades sociais por cor. Além de ser instrumento confiável de medida para os censos, o que a PNAD-76 revelou foi que o moreno é uma categoria que revela pouco da cor, mas muito da situação social daqueles pode significar a possibilidade de ascenção.

O método empregado nos censos demográficos, de perguntas induzidas, embora imperfeito, é satisfatório porque falando em cor não só faz com que o entrevistado seja remetido para o domínio da oposição propriamente social mas, ao mesmo tempo, induz o bora parecendo confundir, revelou que as perguntas do censo pretendem abarcar tanto o gulo. A análise de Wood (1991) aponta ainda para o fato de que as respostas às periântas do censo também mostram um ideal de ascenção e branqueamento e uma preferência

pelos mais claros, já que $38 \%$ dos pretos se autoclassificaram como pardos.
Mas se pretos podem se classificar como pardos parece que nem pretosia podem se classificar como brancos. Assim, o limite social imposto pelos nem pardos pelas oposições preto versus branco, limite que impede que pretos pela cor é definido brancos ocupem o lugar de brancos. Essa maior mobilidade de pretos des ou os não Wood a partir da comparação entre os censos de 50 e 80 é um indicador de que as perguntas do censo podem ainda, se analisadas diacronicamente, revelar a movimentação
das pessoas nessas categorias. O mito do branqueamento, o operador lógico que organiza nossa sociedade, faz com que os entrevistados na busca de se identificarem com os mais historicamente as respostas vê-se que a barreira imposta ao branqueamento na passagem de pretos e pardos a brancos, confirma o dito popular: "passou de branco é preto", ou na quase pretos",

As perguntas do censo e a PNAD-76 com a pergunta em aberto revelam um sistema classificatório de cor e raça que foge das oposições que conotam o lugar social buscando aquelas categorias que falam do valor: mais, quase, menos etc... Nosso sistema classificatório, que Degler (1971) viu como tendo no mulato sua válvula de escape, é revelado, nas respostas a estes dois instrumentos de medida de alcance nacional, como um 
sistema organizado por um princípio de hierarquia que procura encobrir a oposição que revela posição social. Esse sistema falando de hierarquia e não de oposição é bem diverso de outros que buscam a oposição e não falam em hierarquia, como bem demonstrou Peter Fry (1991).

A hierarquia que constrói diferenças valorizando os mais claros e constrangendo os mais escuros não é senão um outro modo de expressar oposição. As cores das pessoas no Brasil são referências fundamentais porque ao falar nas cores e na ausência de cor estamos conotando distinções no social e, ao mesmo tempo, falando de origem, dos vértices de um triângulo imaginário que fala de nossos heróis fundadores.

O censo de 1991, refinando esse quesito, fez os entrevistados responderem à pergunta: "Qual a sua cor ou raça?" e escolherem entre branco, preto, amarelo, pardo e indígena. Dessa forma, o entrevistado foi induzido a se colocar em um dos vértices do triângulo fazendo com que o termo amarelo não fosse residual mas definisse realmente os asiáticos, que estão fora do triângulo originário, mas que significam uma origem étnica possível.

Voltando aos nossos navegadores e viajantes, aos poetas e exploradores do passado, pode-se dizer que de lá para cá, embora a cor - a emissão de luz - tenha produzido representações e povoado a mente de classificações repletas dessas categorias, muitos significados foram conotados a estas distinções da natureza. Camões usou a metáfora mítica do filho de Clymene negando a cor do dia. E por que não concedendo a cor da noite? No século XX e no Brasil esses muitos termos servem ora para designar o lugar social, ora a origem, ora a dimensão do branqueamento, da metonímea, da contigüidade. A dimensão do gradiente, da hierarquia que se constrói por aproximação tem no moreno o seu ponto de maior síntese. O moreno é a metonímea por excelência porque o termo pode ser usado para falar dos três domínios de classificação. Moreno é preto, mas também branco de cabelo escuro. Moreno é preto, mas também pardo ou preto mais claro. A categoria moreno revela também a cultura. ${ }^{8}$

O sistema de classificação ou de identidade, agora podemos chamar de racial ou étnica, do Brasil contemporâneo foge dos textos acadêmicos e enche o discurso das pessoas comuns, nas ruas, nos botequins, na voz dos narradores de partidas de futebol e nas diversas situações sociais de uma sociedade que se pensa misturada e não segregada. Através da discussão de um instrumento de medida usado para quantificar indicadores sociais vimos o alcance e a complexidade desse intrincado modo de falar muito de cor sem falar de oposição.

\section{REFERÊNCIAS BIBLIOGRÁFICAS}

CAMÕES, L., 1925. Os Lusíadas. Rio de Janeiro: Livraria Imprensa/Civilização Editora.

CASTRO, H. M. M., 1995. A cor inexistente. Relações raciais e trabalho rural no Rio de Janeiro pós-abolição. Estudos Afro-Asiáticos, 28:101-127.

Na Serra da Barriga, em 1988, uma senhora vendedora de uma barraca de bebidas ao ser perguntada que festa era aquela disse, "é a festa dos morenos". 
CORREA, M., 1982. As Ilusões da Liberdade: a Escola Nina Rodrigues e a Antropologia no Brasil. Tese de Dooutorado, São Paulo: Antropologia, Universidade Estadual de Campinas.

DA MATTA, R., 1980. Relativizando: Uma Introdução à Antropologia. Petrópolis: Vozes.

DEGLER, C. M., 1971. Nem Preto, nem Branco: Escravidão e Relações Raciais no Brasil e nos Estados Unidos. Rio de Janeiro: Editorial Labor no Brasil.

FRY, P., 1991. Politicamente correto em um lugar, incorreto em outro? (Relações raciais no Brasil, nos Estados Unidos, em Moçambique e em Zimbábue). Estudos Afro-Asiáticos, 21:167-177.

HASENBALG, C., 1991. Notas sobre a pesquisa das desigualdades raciais e bibliografia selecionada. In: Desigualdade Racial no Brasil Contemporâneo (P. A. Lovell, org.). Belo Horizonte: Cedeplar/Face/UFMG

MAGGIE, Y., 1993. Florestan Fernandes e as categorias nativas: análise do sistema de classificação racial no Brasil. In: Encontros com a Antropologia. I. Identidade, Imigração $e$ Memória (M. C. S. Costa \& Pinto, M. T., orgs.), pp. 73-83, Curitiba: Curso de Mestrado em Antropologia Social do Departamento de Antropologia, Universidade Federal do Paraná.

MARINHO, C., 1988. Onda Negra Medo Branco. Rio de Janeiro: Brasiliense.

PNAD (Pesquisa Nacional por Amostra de Domicílio), 1976. Fundação Instituto Brasileiro de Geografia e Estatística. Rio de Janeiro: IBGE.

REIS, J. J., 1986. Rebelião Escrava no Brasil; a Revolta Malê (1835). São Paulo: Brasiliense.

SILVA, N. V., 1988. Cor e processo de realização sócio-econômica. In: Estrutura Social, Mobilidade e Raça (C. Hasenbalg \& N. V. Silva, orgs.), pp. 144-163, Rio de Janeiro: Vértice.

SCHWARCZ, L. M., 1990. Retrato em Preto e Branco. São Paulo: Companhia das Letras.

SKIDMORE, T. E., 1991. Fact and myth: discovering a racial problem in Brazil. Population, nationalism and ethnic conflict. Institute for International Studies, Brown University. U.S.A. (mimeo.)

WOOD, C. H., 1991. Categorias censitárias e classificações subjetivas de raça no Brasil. In: Desigualdade Racial no Brasil Contemporâneo (P. A. Lovell, org.). Belo Horizonte: Cedeplar/Face/UFMG. 


\title{
15 ENTRE O MITO E OS FATOS: RACISMO E RELAÇÕES RACIAIS NO BRASIL ${ }^{1}$
}

\author{
Carlos Hasenbalg
}

As imagens sobre a peculiaridade e a originalidade das relações entre brancos e negros no Brasil vem de longa data. Desde os anos finais do Império e início da República já se falava que o Brasil tinha escapado do problema do preconceito racial. Esta idéia surgia da comparação implícita ou explícita com a situação racial observada nos Estados Unidos naquela época. As elites de outros países da América Latina faziam a mesma comparação, chegando a conclusões semelhantes (Rout, 1976; Andrews, 1980; Wright, 1990).

No que diz respeito à experiência histórica dos descendentes de escravos africanos e às relações entre brancos e negros, o Brasil, longe de ser um caso original, apresenta uma série de características em comum com os países da América Latina de língua espanhola. Pode-se então falar de um tipo latino de relações raciais, diferente dos padrões raciais vigentes nos Estados Unidos e no Caribe de colonização não ibérica. ${ }^{2}$

Dois parecem ser os pontos centrais em torno dos quais se estabelecem as semelhanças entre o Brasil e os outros países latino-americanos. O primeiro deles é o embranquecimento, ou ideal do branqueamento, entendido como um projeto nacional implementado por meio da miscigenação seletiva e políticas de povoamento e imigração européia. ${ }^{3} \mathrm{O}$ segundo é a concepção desenvolvida por elites políticas e intelectuais a respeito de seus próprios países, supostamente caracterizados pela

Agradeço a Nelson do Valle Silva pelas sugestões no início da elaboração deste trabalho. Sou grato também pelos comentários, sugestões e críticas feitas à primeira versão por Peter Fry, Fernando Rosa Ribeiro, Luiz Werneck Vianna e Cesar Guimarães. Este trabalho foi originalmente apresentado no IV Congresso Afro-Brasileiro, realizado na Fundação Joaquim Nabuco, Recife, 17-20 de abril de 1994, e posteriormente publicado em Dados - Revista de Ciências Sociais, 38(2):355-374, 1995.

2 Uma interpretação diferente da variante ibérica das relações raciais pode ser encontrada em Hoetink (1967). Sansone (1994:3) sintetiza assim o padrão latino ou ibérico: "As relações raciais na América Latina podem ser caracterizadas por um alto grau de miscigenação, uma tradição sincrética no campo da religião e da cultura popular, um continuum de cor e uma norma somática hegemônica que tem historicamente colocado os fenótipos negros e índios na escala mais inferior da noção de 'boa aparência'.[...] Esse tipo de relações raciais tem oferecido espaço para a manipulação da identidade étnica assim como não tende a fomentar a mobilização étnica" (vide também Sansone, neste volume).

3 Na análise de Peter Wade do caso colombiano, que não deixa de fazer sentido para o Brasil, miscigenação ou mistura racial (mestizage) não são apenas ideologias, mas também um conjunto de práticas sociais. Branqueamento é a versão hierárquica e discriminatória da mistura racial (Wade, 1993:19 e 42). Em outros termos, miscigenação aponta para homogeneidade e inclusão e se contrapõe às normas de separação e pureza vigentes em outros sistemas raciais. Mas a mistura racial é também um passo no caminho ao branqueamento, resultado final esperado que implica hierarquia e valorização negativa de negros $\mathrm{e}$ índios. O lado mais visível do branqueamento como projeto nacional encontra-se nas políticas de promoção e subsídio à imigração européia (mais ou menos bem-sucedidas nos diferentes países da região) e na recorrência da legislação que proibiu a imigração de africanos e asiáticos (vide Ramos, neste volume e Seyferth, neste volume). A ausência de dados oficiais e censitários sobre cor ou raça da população na maioria dos países do continente é também sugestiva. Ora a composição racial destes países é considerada socialmente irrelevante (devido à propalada democracia racial), ora se trata de reforçar a invisibilidade do segmento negro e mestiço da população. 
harmonia e tolerância racial e a ausência de preconceito e discriminação racial. Notando desde já a distância entre representações e realidade, esta última concepção coexiste, em todos os casos, com a subordinação social ou a virtual desaparição dos descendentes de africanos.

O ideal do branqueamento tem sido interpretado como resultado da tensão existente entre as teorias racistas oriundas da Europa e dos Estados Unidos e assimiladas na região, e a realidade racial desses países, caracterizada pela forte presença de populações negras, indígenas e racialmente misturadas (Skidmore, 1974; Wright, 1990):

A crença na inferioridade genética das raças não brancas e na sua incapacidade de ascender à civilização foi contrabalançada por uma crença na seleção natural e social, que, através da mestiçagem, conduziria a um povo branco (pelo menos na aparência) num futuro próximo. (Seyferth, 1986:54)

O branqueamento, como projeto nacional dos países da região, configurou-se claramente no final do século XIX. Contudo, seus fundamentos mais longínquos podem ser encontrados no funcionamento dos sistemas coloniais português e espanhol. Nesses sistemas, caracterizados pela ausência de distinções raciais dicotômicas e regras de hipodescendência racial, foi possível a um certo número de não brancos a ascensão paulatina em uma sociedade altamente hierárquica e pigmentocrática. O primeiro degrau dessa longa trajetória era sair da condição de escravo mediante alforria ou fuga; o último, só plausível para uns poucos mestiços claros, consistia em ter aceitação no seio do grupo branco dominante. Fora do Brasil, e a partir de 1795, foi possivel tornar-se legalmente branco por meio de cédulas de gracias al sacar, vendidas pela Coroa espanhola.

Com todos os pressupostos racistas que o caracterizaram, o ideal do branqueamento propunha como solução harmoniosa para o problema racial dos países da região a desaparição gradual dos negros pela via de sua absorção pela população branca.

Como resultado da derrota do nazismo na Segunda Guerra Mundial e da emergência, no Terceiro Mundo, de nações independentes de população não branca, o ideal do branqueamento perde legitimidade intelectual por volta da década de 1950. Contudo, essa perda de legitimidade não evitou que esse ideal criasse raizes profundas no grupo cuja desaparição era esperada, levando tendencialmente o próprio negro à sua autonegação.

No passado como agora, a contrapartida de sistemas raciais que admitem o deslocamento lento ao longo do contínuo de cor é uma estética branca racista que desvaloriza o extremo negro do espectro e condiciona atitudes e comportamentos dos não brancos. "Naturalmente, a hierarquização das pessoas em termos de sua proximidade a uma aparência branca ajudou a fazer com que indivíduos de pigmentação escura desprezem a sua origem africana"' (Rout, 1976:132). Expressões como "cabelo ruim", "cabelo bom" e "melhorar a raça" são comuns ao português e ao espanhol falados nas Américas. Não é estranho que esta forte pressão no sentido do branqueamento resulte em que "[...] negros e mulatos fazem o melhor possível para parecer mais brancos e procuram com energia dissimular ou desenfatizar suas origens negróides" (Rout, 1976:245).

A tentativa de uma parte da população negra e mestiça de se aproximar tanto quanto possível do extremo branco do espectro e a própria percepção social da raça por meio de um contínuo de cores leva a uma fragmentação das identidades raciais, que pode ser captada na imensa variedade de categorias usadas para designar variações de aparência física. Deve ser ressaltado, por sua vez, que essa fragmentação se relaciona com as difi- 
culdades notadas na construção de identidades coletivas baseadas no critério racial e o baixo grau de politização do conflito racial nos países da região. O Partido Independiente de Color, no início deste século em Cuba (reprimido e eliminado violentamente em 1912), e a Frente Negra Brasileira da década de 1930 (também fechada em 1937 pela ditadura do Estado Novo) aparecem no panorama histórico deste século mais como exceções à tendência geral da região. Acrescente-se a isso as não poucas dificuldades que os movimentos negros contemporâneos encontram para mobilizar um apoio de massa.

Parece possível afirmar que nenhum outro país latino-americano construiu um dogma tão elaborado e persistente como o da democracia racial brasileira. O que existe nesses outros países é uma versão fraca do mito racial brasileiro, como pode ser comprovado nos estudos recentes de Winthrop R. Wright (1990), sobre a Venezuela, e de Peter Wade (1993), sobre a Colômbia. ${ }^{4}$

Um dos componentes do mito racial, tanto na sua versão forte, a brasileira, como na versão fraca, no resto da América Latina, é a reconstrução idílica do passado escravista. É difícil pensar em qualquer país latino-americano onde inexista um grupo de historiadores tradicionais que deixe de proclamar a benevolência superior do sistema escravista de suas respectivas sociedades.

Outro forte ingrediente desse mito racial é a ênfase na miscigenação, tida como indicadora de tolerância racial, e a apologia da mestiçagem. Ainda está para ser feito um estudo aprofundado sobre o paralelismo existente entre a noção freyreana de metarraça brasileira, a de "raça cósmica" do mexicano José Vasconcelos e a imagem do café con leche que os venezuelanos usam para descrever a cor da população (vide Martínez-Echazábal, neste volume).

Contudo, como sugere Hanchard (1992:24), os teóricos da miscigenação e da democracia racial parecem ter confundido a mistura racial no plano biológico com as interações raciais no sentido sociológico. Supondo que a primeira ocorreu sem conflito (o que é empiricamente falsificável), sugerem que as últimas também existiriam sem conflito.

As noções acerca da democracia racial foram formuladas por intelectuais a partir de idéias preexistentes e, no caso do Brasil, foram cncampadas pelo Estado e oferecem a definição oficial da situação. Mais ainda, essas idéias estão parcialmente incorporadas ao senso comum racial da população. Ao se falar ou agir contra essa definição pode-se incorrer em custos políticos e sociais elevados. Um desses custos é a sempre repetida acusação de se tentar importar um problema que inexiste na sociedade brasileira.

No final deste trabalho serão feitas algumas considerações sobre a forma como a população processa e assimila as idéias dominantes no campo racial. O que interessa destacar, neste momento, é que esse núcleo comum do mito racial latino-americano

$\Lambda$ noção de mito para qualificar a "democracia racial" é aqui usada no sentido de ilusão ou engano e destina-se a apontar para a distância entre representação e realidade, a existência de preconceito, discriminação e desigualdades raciais c a sua ncgação no plano discursivo. Esta noção não corresponde, por"tanto, ao conceito de mito usado na Antropologia. Em comunicação pessoal, Peter Fry sugeriu-me que a "democracia racial" pode ser também entendida como mito no sentido antropológico clássico. Este mito ou conjunto de representações scria aquilo que é especilicamente brasileiro, informando a vida cotidiana e ensinando-nos que a cordialidade é melhor que o confronto. Contudo, subsiste a possibilidade que em sociedades complexas, como a brasileira, os mitos fundantes apresentem um componente de "falsa consciência", dissimulando ou representando como naturais e inevitáveis certas formas de dominação. 
preenche uma importante função de controle social, apontando para a unidade e homogeneidade nacional e ocultando a existência de divisões raciais e sociais.

Enfim, como aponta Agier (1992:103-104), para o Brasil “" [...] o mito da democracia racial se firmou, progressivamente, como uma imposição política: a proibição social, ou até institucional, de se falar em racismo e preconceito racial"'. Trata-se então de desvendar o papel político desse mito.

Em um ensaio clássico de 1960, E. E. Schattschneider chamava a atenção para o fato de que o problema crucial da política é a administração do conflito. Uma das maneiras mais eficientes de controlar um conflito é não providenciar uma arena para o mesmo, nem criar uma agência pública com poder para fazer algo a seu respeito. Chamou a isto de "mobilização do viés".

Todas as formas de organização política têm um viés a favor da exploração de certo tipo de conflitos e a supressão de outros porque organização é a mobilização do viés. Algumas questões são organizadas dentro da política ao mesmo tempo que outras são excluidas dela. (Schattschneider, 1960:70)

Esta perspectiva permite sugerir que o mito racial brasileiro e latino-americano funciona como o viés mobilizado pelos grupos dominantes para manter a questão do racismo como um conflito que permanece em estado apenas latente, sem que ele irrompa na esfera pública do debate político.

O resultado disso, como aponta Wade ao analisar o caso da Colômbia, é que:

Os negros muito provavelmente se encontram encurralados entre, de um lado, ideologias de branqueamento que privilegiam a brancura (ou as misturas de cor clara) e discriminam contra a negritude e, de outro lado, idéias de homogeneidade nacional que retoricamente incluem os negros como iguais mas, pelo mesmo motivo, lhes negam um status especifico (isto é, de alvo da discriminação racial). A discriminação contra os negros e, de fato, os próprios negros, retiram-se para o fundo da cena. (Wade, 1993:37)

As representações a respeito das relações raciais no Brasil, elaboradas na primeira metade deste século, particularmente aquelas sobre o caráter harmonioso e não-conflitivo dessas relações (Freyre, 1933; Pierson, 1942; Tannenbaum, 1946) só começam a ser desmontadas no campo das Ciências Sociais na década de 1950 . Foi no início desta década que a UNESCO, então empenhada em refutar os dogmas racistas que haviam culminado no nazismo, patrocinou um conjunto de pesquisas sobre esse tema, destacando a situação do Brasil. A intenção original desses estudos era a de poder transmitir para o resto do mundo a receita brasileira de relações raciais harmoniosas. O resultado dos mesmos não confirmou as expectativas originais; pelo contrário, a auto-imagem e idealizações raciais do Brasil sofreram danos de não pouca monta. As pesquisas foram realizadas no Norte, Nordeste e Sudeste do País e em todas elas foi constatada uma forte associação entre cor ou raça e status socioeconômico.

Nos trabalhos antropológicos sobre o Norte e o Nordeste, ainda influenciados pela ótica de Freyre e Pierson, a raça foi relegada a um lugar secundário na atribuição da posição dos indivíduos no sistema de estratificação social: as condições generalizadas de subdesenvolvimento e pobreza explicariam a concentração de negros e mestiços na base da hierarquia social (vide Guimarães, neste volume). Já nos estudos realizados no Sudeste, particularmente em São Paulo, produziu-se ampla documentação confirmando a exis- 
tência de preconceitos e discriminação racial. Pela primeira vez na história dos estudos sobre o negro e as relações raciais no Brasil, a produção acadêmica desmentia frontalmente o mito da democracia racial. O trabalho, inicialmente patrocinado pela UNESCO, teve seqüência nos anos 50 e $60 \mathrm{com}$ as pesquisas da chamada escola paulista de relações raciais, desenvolvida, entre outros, por Florestan Fernandes, Fernando Henrique Cardoso e Octávio Ianni (vide Arruda, neste volume).

O período que vai de aproximadamente 1965 até o final da década de 1970 não foi dos mais estimulantes para pesquisar e escrever sobre rclações raciais no Brasil: o tema racial passou a ser definido como questão de "segurança nacional". Em 1969, as aposentadorias compulsórias atingiram os mais destacados representantes da escola paulista de relações raciais. Além disso, houve a falta de dados: por " motivos técnicos" a pergunta sobre cor foi eliminada do censo demográfico de 1970.

Com a abertura política iniciada no Governo Geisel e a disponibilidade de novos dados oficiais (Pesquisa Nacional por Amostra de Domicílios - PNAD de 1976 e Censo Demográfico de 1980) foi possível retomar os estudos sobre relações raciais no Brasil. Este não é o espaço para resenhar detalhadamente a produção acadêmica que se acumula desde o final dos anos 70, contudo, devo assinalar que essa produção ampliou tematicamente e refinou tecnicamente as áreas de investigação desenvolvidas no projeto da UNESCO e continuadas pela escola paulista. Em matéria de interpretação das desigualdades raciais, essa produção mais recente deixou de enfatizar a herança ou legado do passado escravista e deu destaque às práticas racistas e discriminatórias do presente, que atuam no sentido de perpetuar essas desigualdades.

Os resultados das pesquisas mais recentes são de estarrecer os que ainda acreditam na neutralidade do critério racial em matéria de apropriação das oportunidades sociais. Eles demonstram que negros e mestiços (pretos e pardos na denominação oficial do Instituto Brasileiro de Geografia e Estatística - IBGE, ou não brancos, como serão chamados aqui alternativamente) estão expostos a desvantagens cumulativas ao longo das fases do ciclo de vida individual, e que essas desvantagens são transmitidas de uma geração para outra.

Estudos demográficos demonstraram as disparidades raciais quanto às probabilidades de superar o primeiro ano de vida e na esperança de vida ao nascer. Em 1980, a mortalidade infantil por mil nascidos vivos era de 77 para brancos e 105 para o conjunto de pretos e pardos; esta taxa de pretos e pardos em 1980 correspondia a do grupo branco em 1960 (Tamburo, 1987). Igualmente, a expectativa de vida ao nascer de pretos e pardos é significativamente inferior a dos brancos; em 1980 era de 66,1 anos para brancos e 59,4 para pretos e pardos, sendo que essa diferença de 6,7 anos é muito próxima a de 7,5 anos existente em 1950 (Wood \& Carvalho, 1988; Berquó et al., 1986; Berquó, 1988; Tamburo, 1991).

As pesquisas sobre educação indicam que crianças não brancas completam menos anos de estudo do que as brancas, mesmo quando se considera crianças da mesma origem social ou renda familiar per capita (Barcelos, 1992a, 1992b; Hasenbalg \& Silva, 1990; Rosenberg, 1987a, 1987b, 1990, 1991). Uma ilustração das disparidades educacionais entre brancos e não brancos pode ser feita ao considerar o grupo etário de 15 a 19 anos que, pelo critério legal, já deveria ter completado o ensino de Primeiro Grau. A proporção de analfabetos nessa faixa etária, em 1990, ainda era de 4,9\% para os brancos e $14,4 \%$ para pretos e pardos. Apenas $34,8 \%$ dos brancos e $15,4 \%$ dos pretos e pardos dessa 
idade tinham completado o Primeiro Grau. As disparidades no acesso ao ensino superior são ainda mais acentuadas. Em 1990, a proporção de pessoas em idade ativa que tinha completado 12 ou mais anos de estudos era de $11,8 \%$ de brancos e somente $2,9 \%$ de pretos e pardos. A desigualdade educacional entre brancos e não brancos irá se refletir posteriormente em padrões diferenciados de inserção desses grupos de cor na estrutura ocupacional.

Em termos de etapas do ciclo de vida, à obtenção de educação formal seguem-se a incorporação no mercado de trabalho e a constituição de novas famílias, que formam as unidades básicas do sistema de estratificação social. Começando por este último aspecto, sabe-se que no Brasil os casamentos inter-raciais são mais freqüentes do que em outras sociedades multirraciais, e que é por meio desses casamentos que o processo de miscigenação racial, iniciado no período colonial, tem continuidade no presente. Contudo, os poucos estudos sobre o tema mostram que aproximadamente $80 \%$ dos casamentos no Brasil são racialmente endogâmicos e que este padrão de endogamia está longe do que seria de esperar se o critério cor ou raça fosse irrelevante na seletividade conjugal (Berquó, 1991; Lazo, 1988; Scalon, 1992; Silva, 1987, 1991).

O tema da participação dos grupos raciais ou de cor no mercado de trabalho é um dos que está melhor estudado e mais tem atraído a atenção dos pesquisadores. Não poderia ser de outra forma, dado o papel determinante que as modalidades de inserção no mercado de trabalho têm na alocação de individuos e famílias na hierarquia de classes e estratos sociais. Resumindo e simplificando, este conjunto de estudos indica que negros e mestiços estão expostos a diversas práticas discriminatórias no mercado de trabalho. Além de ingressar nele com uma dotação menor de educação formal que a dos brancos, os negros e mestiços estão expostos à discriminação ocupacional, pela qual a avaliação de atributos não-produtivos, como a cor das pessoas, resulta na exclusão ou acesso limitado a posições valorizadas no mercado de trabalho. Soma-se a isso a discriminação salarial, evidenciada nas menores taxas de retorno à educação e à experiência obtidas por não brancos, sendo que a diferença na taxa de retornos nos níveis educacionais aumenta. Há ainda evidências de que quando já ocupam empregos no mercado formal de trabalho, os não brancos enfrentam bloqueios na mobilidade dentro de suas ocupações. As barreiras raciais existem no recrutamento para os empregos como nas promoções dentro dos empregos. Fsse conjunto de fatores resulta em uma concentração desproporcional de pretos e pardos nas ocupações manuais urbanas, particularmente nas menos qualificadas e pior remuneradas, como é o caso da construção civil, emprego doméstico e prestação de serviços pessoais. Como contrapartida, há uma participação proporcional pequena de não brancos nas ocupações não manuais, sendo a exclusão mais acentuada no topo da hierarquia ocupacional. Estes padrões diferenciados de participação dos grupos de cor no mercado de trabalho se traduzem em uma valorização altamente desigual do trabalho desses grupos: a renda média do trabalho de pretos e pardos é pouco menos da metade da dos brancos (Bairros, 1986, 1987; Bairros et al. 1992; Batista \& Galvão, 1992; Castro \& Guimarães, 1993; Chaia, 1988; Hasenbalg, 1992; Lovell, 1989, 1992; Oliveira et al., 1983; Porcaro, 1988; Silva \& Lima, 1992; Silva, 1985; Telles, 1990, 1994).

A ausência, no Brasil, de guctos raciais nitidamente delineados tem levado com freqüência a idéia de que existe nos espaços urbanos uma segregação residencial das classes sociais, mas não dos grupos raciais. Contrariando essa noção, o único trabalho disponível sobre o tema (Telles, 1993) indica que existe no País uma segregação residencial moderada entre os grupos de cor e que essa segregação aumenta junto com os níveis 
de renda. Como aponta o autor, este padrão, associado ao tamanho reduzido da classe média negra, permite que os bairros de classe média continuem sendo predominantemente brancos. Ao mesmo tempo, a menor segregação por cor entre os pobres urbanos é relacionada a níveis comparativamente mais altos de interação inter-racial, sendo este o caso da maior freqüência de amizades e casamentos inter-raciais (Telles, 1993:16-17).

Por último, as pesquisas sobre mobilidade social e raça, levando em conta o conjunto de processos sociais acima referidos, enfocam o papel da filiação racial na transmissão intergeracional das desigualdades sociais. Os resultados mais relevantes apontam não só para as menores taxas de mobilidade ascendente para os estratos médios e altos experimentadas pelos não brancos, como também para as maiores dificuldades encontradas pelas famílias não brancas de classe média para transmitir aos filhos as posições sociais conquistadas (Silva, 1981; Hasenbalg, 1985; Hasenbalg \& Silva, 1988).

O conjunto de investigações que acaba de ser referido vasculhou e esmiuçou os principais mecanismos que levam a sociedade brasileira a produzir resultados desiguais para brancos, negros e mestiços. Como tais, eles apresentam implicações importantes para a eventual formulação de políticas públicas que pretendam diminuir as desigualdades raciais existentes.

Por outro lado esse tipo de estudos conta com uma limitação que deriva da natureza dos dados utilizados. A quase totalidade dos trabalhos revisados foi produzida a partir dos dados dos censos demográficos e pesquisas domiciliares realizados pelo IBGE. $O$ procedimento das pesquisas consiste em estabelecer relações estatísticas entre a cor declarada pelas pessoas entrevistadas nas pesquisas do IBGE e outras características socioeconômicas e demográficas dessas mesmas pessoas.

Pela sua própria natureza, esses dados são inadequados para estudar tanto a forma como as pessoas vivenciam o racismo e as relações raciais na vida cotidiana quanto a operação de práticas racistas dentro de determinados contextos institucionais e organizacionais. ${ }^{5}$ Aqui são claras as vantagens das abordagens menos quantitativas e mais antropológicas, mas esta área de pesquisa se encontra ainda em uma fase incipiente. Alguns estudos sobre racismo institucional, particularmente nos locais e na esfera do trabalho, foram feitos recentemente na Bahia (Guimarães \& Agier, 1990; Guimarães, 1993; Castro \& Guimarães, 1993; Silva, 1993). São também da Bahia alguns dos estudos etnográficos mais recentes sobre relações raciais no espaço urbano (Agier, 1990, 1992; Sansone, 1992, 1993, 1994). Vários outros temas não foram ainda estudados. Não há constância, por exemplo, de trabalhos publicados que analisem os mecanismos intra-escolares que limitam as oportunidades educacionais das crianças não brancas ou as práticas discriminatórias do aparelho policial (freqüentemente noticiadas pela imprensa) e do sistema judiciário.

Ilustrativo da riqueza do enfoque antropológico do racismo e das relações raciais na vida cotidiana é o trabalho de Sansone (1993), que faz parte de um projeto de pesquisa ainda em andamento (vide também Sansone, neste volume). Baseado no relato de seus

Não pode passar desapercebida neste ponto a longa tradição de pesquisas antropológicas sobre cultura negra, particularmente centrada no estudo das chamadas religiões afro-brasileiras. Não obstante seu valor intrínseco, essas pesquisas nem sempre oferecem clementos de informação sobre a trajetória e a identidade social dos participantes desses contextos culturais na sociedade global, fora dos âmbitos específi-
cos estudados. 
entrevistados em Salvador, Bahia, Sansone delimitou as áreas nas quais a cor das pessoas assume maior ou menor importância na orientação das relações sociais. Distingue assim entre as áreas duras e as áreas moles das relações raciais. As áreas duras são as do trabalho, particularmente a procura do trabalho, o mercado matrimonial e da paquera e os contatos com a polícia. As áreas moles ou espaços negros implícitos estão vinculados ao domínio do lazer, mas incluem também a Igreja Católica, as igrejas de crentes e os círculos espíritas. Nestes espaços ser negro não deveria ser um obstáculo e neles pouco se fala sobre raça ou racismo. Haveria ainda os espaços negros explícitos, geralmente chamados da "cultura negra" (blocos afro, batucada, terreiros e capoeira). Neles, ser negro pode constituir uma vantagem; de fato, os negros são hegemônicos nestes espaços ao tempo que os brancos devem negociar as suas condições de participação (Sansone, 1993:162-163).

Esta interessante distinção entre áreas duras e moles de relações raciais sugere alguns comentários. Em primeiro lugar, o que o antropólogo chama de áreas duras - trabalho e mercado matrimonial - remetem o sociólogo para dois elementos cruciais do sistema de estratificação social: a família e o mercado de trabalho. É na complexa interrelação família, educação e mercado de trabalho que se define o lugar que as pessoas irão ocupar na hierarquia social. É aqui que para uma maioria de negros e mestiços se estruturam as suas condições de exclusão e subordinação. Outros, em número mais reduzido e a título individual, são aceitos via mobilidade ocupacional e social ascendente e casamentos inter-raciais, fatos normalmente associados ao processo de branqueamento.

A terceira área dura de relacionamentos ainda está indiretamente relacionada ao mercado de trabalho e seus desajustes. Desemprego e formas precárias ou ilícitas de integração nesse mercado, amplificadas por uma ótica preconceituosa, dão lugar à distinção popular entre "trabalhadores" e "vadios". Nisto pode estar configurada parte do problema do relacionamento com a polícia.

Por sua vez, as áreas moles de relacionamento, excluindo o espaço das religiões cristãs, são as que alimentam formas antigas e novas de preconceitos e visões estereotipadas do negro. Como o próprio Sansone indica:

A divisão cultural-racial [dos espaços] funciona através de novas visões naturalizantes das diferenças de cor - associar à cor características psicológicas e culturais. [...] Na base desta divisão reside a idéia que ao negro pertence uma natureza diferente, mais genuina, natural, sensual, associada ao corpo e, para alguns, lúdica. $O$ negro teria o que o branco deixou de ter: proximidade à natureza. (Sansone, 1994:14)

Além disso, o fascínio e a atração de muitos brancos por manifestações da cultura negra os leva a participar dessas práticas culturais (escolas de samba, carnaval, pagode, capoeira, umbanda e candomblé, para citar apenas algumas dessas práticas). O convívio inter-racial nesses âmbitos culturais, bem como no domínio geral das atividades de lazer, acaba reforçando as imagens da cordialidade brasileira, da fluidez e brandura das relações raciais no País.

Por trás dessas imagens permanece o fato de que as áreas duras e moles de relacionamento estão estruturadas assimetricamente: os não brancos têm limitado seu acesso às áreas duras (hierarquia ocupacional e casamentos inter-raciais), ao passo que os brancos têm menos restrições no acesso aos espaços da cultura negra. Mesmo as áreas moles da 
cultura e do lazer funcionam assimetricamente, havendo a possibilidade para os brancos de se retirarem aos seus domínios exclusivos de sociabilidade.

Nesta altura cabe ainda arriscar uma especulação sobre o caráter ambivalente dos usos da cultura negra. Para muitos militantes negros essa cultura se constitui no principal instrumento de resgate da auto-estima e da reconstrução positiva de uma identidade racial abalada pela ideologia do branqueamento. Ao mesmo tempo, a cultura negra pode florescer e até ser oficialmente promovida em contextos caracterizados pelo domínio de oligarquias regionais e de práticas de clientelismo político. ${ }^{6}$ Isto aponta para a possibilidade de que a legitimação e mesmo a cooptação da cultura negra e seus símbolos (Fry, 1982) não seja acompanhada de uma mudança significativa na posição relativa dos segmentos negro e mestiço da população na estrutura social do Brasil. Como observou Yvonne Maggie (1989:27) ao analisar os eventos do centenário da abolição em 1988 "[...] o negro no Brasil é assunto do Minc [Ministério da Cultura] e não do Ministério do Trabalho, da Saúde ou da Justiça".

Afinal de contas, para o Estado resulta muito mais econômico destinar migalhas de seu orçamento a sancionar símbolos da cultura negra (tombar a Serra da Barriga e declará-la patrimônio nacional, criar a Fundação Cultural Palmares ou imprimir na moeda a tradicional figura da baiana, como na nota de CR $\$ 50.000,00)$ do que implementar políticas destinadas a corrigir as desigualdades raciais. A integração simbólica do negro, via cultura, pode caminhar e caminhou pari passu à sua subordinação e exclusão social.

Por último, cabe retomar o tema da forma como as pessoas comuns, alheias aos mundos da academia e da militância negra, se apropriam das idéias raciais dominantes. As observações que seguem estão baseadas na pouca evidência disponível a respeito de assunto tão relevante.

Em primeiro lugar pode-se assinalar uma experiência reportada por vários pesquisadores sobre seu trabalho de campo. Trata-se da situação de constrangimento e embaraço inicial criada quando o pesquisador pergunta a seus entrevistados ou informantes sobre a sua cor e sobre as situações de discriminação racial que já vivenciaram. O constrangimento, sentido particularmente por entrevistados de baixa educação, já é uma indicação de que as pessoas não estão acostumadas a falar com naturalidade sobre questões relativas às relações raciais. Em um texto pequeno e extremamente perceptivo, a antropóloga norte-americana Robin E. Sheriff, que durante quase dois anos estudou os discursos cotidianos sobre raça e racismo em uma favela do Rio de Janeiro, conclui que o mito da democracia racial desempenha um papel na contenção dos discursos sobre racismo. $\mathrm{O}$ silêncio e a censura cultural seriam, segundo cla, elementos fundamentais da contraditória cultura racial brasileira. Mas a idéia racial dominante não tem apenas a função de silenciar, já que ela apresenta duas faces, a do mito e a do sonho:

A democracia racial é certamente um mito, mas é também um sonho em que a maioria dos brasileiros de todas as cores e classes sociais deseja acreditar com paixão. Enquanto ele obviamente permite uma tremenda hipocrisia e ofusca a realidade do racismo, o mito da democracia racial é também um discurso moral que afirma que o racismo é nocivo, desnatural e contrário à brasilidade [...] foi somente quando 
afro-brasileiros pobres insistiram repetidamente em que 'todas as pessoas são iguais', que 'o sangue é o mesmo', como eles costumam dizer, que eu fui capaz de reconhecer o poder prescritivo e moral do sonho. Não estavam me falando sobre o mundo social tal como pensam que ele de verdade é, mas como acham que verdadeiramente deveria ser. Ao mesmo tempo que o mito nega a realidade de sua própria opressão, também lhes dá a certeza de sua igualdade inerente, fundamental e lembra a seu opressor como deve se comportar um bom brasileiro. Ele oferece aos afro-brasileiros nho, parece operar como uma totalidede democracia racial, como mito e como sonho, parece operar como uma totalidade, sem que sejam feitas as distinções entre as suas pretensões descritivas e os seus imperativos morais. Como tal, os afro-brasileiros não podem aceitá-lo nem rejeitá-lo totalmente. Eles ficam aprisionados entre a esperança e o silêncio, entre a resistência e a resignação. (Shcriff, 1993:5)

Em outras palavras, as pessoas não se iludem com relação ao racismo no Brasil; sejam brancas, negras ou mestiças, elas sabem que existe preconceito e discriminação racial. O que o mito racial brasileiro faz é dar sustentação a uma etiqueta e regra implícita de convívio social pela qual se deve evitar falar em racismo, já que essa fala se contrapõe a uma imagem enraizada do Brasil como nação. Transgredir essa regra cultural não explicitada significa cancelar ou suspender, mesmo que temporariamente, um dos pressupostos básicos que regulam a interação social no cotidiano, que é a crença na convivência não conflituosa dos grupos raciais. Por um lado, o mito racial brasileiro parece ter funcionado como um elemento de dissuasão para a emergência de grupos e movimentos racistas de extrema direita como os que existem há muito tempo nos Estados Unidos e os que ganharam notoriedade mais recentemente na Europa. Por outro lado, ele individuais e coletivas. Neste sentido, o mito está continuame linhas de ação reivindicatórias do sonho.

Esta interpretação encontra ressonância empírica nos dados de um survey eleitoral realizado em 1986 no município de São Paulo, que incluiu um conjunto de perguntas sobre temas raciais. ${ }^{7} \mathrm{~A}$ análise destes dados indica que a maioria das pessoas tem uma clara percepção dos mecanismos de discriminação racial no Brasil (Hasenbalg \& Silva, funcionamento do mercado de trabalho. Verificou-se que aproximadamente do regras de dos respondentes (67,3\% de brancos e $66,9 \%$ de pretos e pardos) acreditam dois terços minação racial no mercado de trabalho. A segunda pergunta considerada trata discricomponente central dos direitos civis: a questão do tratamento diferenciado de brancos e

Trata-se do projeto "Identidades Coletivas e Democratização: as cleições de $1986 \mathrm{~cm}$ São Paulo". Nos 30 dias que antecederam as cleições de 15 de novembro desse ano foram entrevistadas 573 pessoas de 18
anos e mais, com a seguinte distribuição por cor 408 baulo". Nos amarclos $(2,4 \%)$. As perguntas que aqui interessam foram assim form 151 pretos e pardos $(26,3 \%)$ e 14 zem que existe discriminação contra pretos e mulatos no trabalho - que é muito mais difícil pessoas dirumarem um bom emprego do que para um branco. Outros acham que para progredir cil para eles arpende só da pessoa e não tem nada a ver com a cor da pele. acham que para progredir na vida tudo deas pessoas de cor ou a oportunidade de subir na vida é igual para brancos e pretos?" "2) "Uninação contra os pretos e mulatos são muito mais visados pela policia do que os brancos. Outros dizem que a polícia
investiga qualquer pessoa suspeita, seja qual for a sua cor. $O(A)$ Sr.(a) acha que os pretos e mulatos são
mais visados ou que a cor das pessoas não mais visados ou que a cor das pessoas não tem nada que ver com a ação da polícia?"; 3) "Na sua opi-
nião, o que os pretos e mulotos nião, o que os pretos e mulatos deveriam fazer para defender os seus direitos?"'; 4) "O(A) Sr.(a) é a fa-
vor ou contra a greve de trabalhadores como forma de pressão nas necivor ou contra a greve de trabalhadores como forma de pressão nas negociações salariais?"'. 
não brancos por parte da polícia. Quase três quartos dos entrevistados $(73,5 \%$ de brancos e $73,1 \%$ de pretos e pardos) concordam com o fato de que pretos e pardos são mais visados pela polícia. Observe-se que a percepção da discriminação não varia segundo a cor das pessoas. Brancos e não brancos acreditam que existe discriminação racial. Entre os entrevistados com nível educacional mais elevado aumenta a proporção dos que percebem a discriminação, sugerindo que a educação ajuda a apreender a experiência alheia, melhorando o entendimento dos mecanismos de funcionamento da sociedade.

Estes resultados levam a relativizar a noção de democracia racial na medida em que há uma clara percepção de que as pessoas recebem um tratamento diferenciado segundo a sua cor. Deveria então se esperar que a raça pudesse ser base para movimentos reivindicatórios e a adoção de medidas políticas corretivas. Isto é o que pretendia captar a pergunta a respeito das estratégias a serem adotadas pelo grupo discriminado. As respostas à pergunta admitiam as possibilidades de (1) cada um exigir sozinho que os seus direitos sejam respeitados, (2) organizar um movimento no qual só participem pretos e mulatos e (3) organizar um movimento no qual também participem brancos preocupados com o problema. As respostas a essa pergunta indicam clara rejeição à possibilidade de que se relegue ao plano individual a solução do problema percebido (apenas $8 \%$ de brancos e $11,3 \%$ de não brancos aprovam esta alternativa), o que implica, em contrapartida, que a solução desse problema deve ser encontrada mediante a mobilização coletiva. No entanto, também é forte a rejeição à idéia de que esse movimento coletivo seja restringido ao grupo discriminado (somente $5,2 \%$ de brancos e $7,2 \%$ de não brancos aprovam esta alternativa). A solução endossada pela grande maioria $(83,1 \%$ de brancos e $75,3 \%$ de não brancos) é a de um movimento amplo, de caráter interétnico ou inter-racial, baseado portanto na empatia por parte dos brancos em relação ao problema racial. A implicação disso é que se está rejeitando a possibilidade de um movimento baseado na confrontação entre os dois grupos raciais.

Harmonia e evitação do confronto racial parecem ser a expressão da natureza da ideologia racial no Brasil. Existe um problema racial e ele demanda ação coletiva para ser corrigido. Por outra parte, existe o valor ou ideal de convivência harmônica entre grupos raciais e esse ideal é comum a brancos e não brancos. Cabe indagar se a harmonia é um valor geral no sistema de representações da sociedade brasileira, no sentido de ser uma norma aplicável a todas as áreas de convívio social. Sobre isto, foi interessante considerar as respostas a uma pergunta sobre a greve como instrumento legítimo para encaminhar o conflito de classe. Notou-se que a greve conta com elevado grau de legitimidade para dirimir os conflitos entre capital e trabalho; mais da metade dos respondentes é favorável à greve como instrumento de pressão nas negociações salariais. Isto permite questionar a necessidade de relações harmônicas como norma generalizada de convívio social. A impressão que emerge é que a idéia de harmonia é algo relativamente restrito ao plano da ideologia racial brasileira (Hasenbalg \& Silva, 1993:153-157).

Este talvez seja um fato digno de ser levado em conta por todos aqueles que adotam uma postura contrária ao racismo no Brasil. A ênfase em relações raciais desprovidas de confronto pode estar relacionada às dificuldades enfrentadas pelo movimento social dos negros para epcaminhar as suas reivindicações específicas e ampliar a sua base social.

É possivel que o dilema racial brasileiro possa ser redefinido nestes termos: como legitimar a diversidade cultural e ao mesmo tempo assegurar a integração social igualitária dos grupos étnicos e raciais? 
Nos últimos 20 anos o movimento social dos negros e estudiosos das relações raciais têm posto ênfase tanto no particular e na diferença, recortados no plano cultural, quanto no universal, que aponta para a cidadania. Isto tendeu a ser feito predominantemente a partir de uma leitura externa do Brasil, inspirada nas experiências dos Estados Unidos e da descolonização dos países africanos. Talvez a nova agenda deva preservar o equilíbrio entre o particular e o universal, mas partindo de uma interpretação do Brasil nos seus próprios termos e não de uma leitura a ele externa.

\section{REFERÊNCIAS BIBLIOGRÁFICAS}

AGIER, M., 1990. Espaço urbano, família e status social. o novo operariado baiano nos seus bairros. Cadernos do CRH, 13.

AGIER, M., 1992. Etnopolítica. A dinâmica do espaço afro-baiano. Estudos Afro-Asiáticos, 22.

ANDREWS, G. R., 1980. The Afro-Argentine of Buenos Aires 1800-1900. Madison: The University of Wisconsin Press.

BAIRROS, L., 1986. O negro na força de trabalho. Cadernos do CEAS, 140.

BAIRROS, L., 1987. Pecados no Paraíso Racial. O Negro na Força de Trabalho da Bahia: 1950-1980. Dissertação de Mestrado, Salvador: Faculdade de Filosofia e Ciências Humanas, Universidade Federal da Bahia.

BAIRROS, L., et al. 1992. Negros e brancos num mercado de trabalho em mudança. Ciências Sociais Hoje 1992, Rio de Janeiro, Anpocs.

BARCELOS, L. C., 1992a. Educação: Um Quadro das Desigualdades Raciais. Estudos AfroAsiáticos, 23.

BARCELOS, L. C., 1992b. Raça e Realização Educacional no Brasil. Tese de Mestrado, Rio de Janeiro: Iuperj.

BATISTA, M. A. R. \& GALVÃO, O. M. R., 1992. Desigualdades raciais no mercado de trabalho brasileiro. Estudos Afro-Asiáticos, 23.

BERQUÓ, E. S., 1988. Demografia da desigualdade: Algumas considerações sobre os negros no Brasil. Anais da Abep, 3.

BERQUÓ, E. S., 1991. Como se casam negros e brancos no Brasil. In: Desigualdade Racial no Brasil Contemporâneo (P. A. Lovell, org.). Belo Horizonte: Cedeplar/Face/UFMG.

BERQUÓ, E. S., et al., 1986. Estudos da dinâmica demográfica da população negra no Brasil. Textos Nepo, 9.

CASTRO, N. A. \& GUIMARÃES, A. S., 1993. Desigualdades raciais no mercado e nos locais de trabalho. Estudos Afro-Asiáticos, 24.

CHAlA, M. W., 1988. Negro, entre o trabalho forçado e o trabalho restrito. São Paulo em Perspectiva, 2(2).

FREYRE, G., 1933. Casa Grande \& Senzala. Rio de Janeiro: Maia \& Schmidt.

FRY, P., 1982. Para Inglês Ver. Rio de Janeiro: Zahar. 
GUIMARÃES, A. S., 1993. Opcrários e mobilidade social na Bahia: Análise de uma trajetória individual. Revista Brasileira de Ciências Sociais, 8(22).

GUIMARÃES, A. S. \& AGIER, M., 1990. Identidades em conflito, técnicos e peões na petroquímica na Bahia. Revista Brasileira de Ciências Sociais, 18.

HANCHARD, M., 1992. Taking exception: narratives of racial equality in Brazil, Mexico and Cuba. Seminário Internacional Racismo e Relações Raciais nos Países da Diáspora Africana. Rio de Janeiro: Centro de Estudos Afro-Asiáticos, abril de 1992.

HASENBALG, C. A., 1985. Race and socioeconomic inequalities in Brazil. In: Race, Class and Power in Brazil (P. M. Fontaine, org.). Los Angeles: Center for Afro-American Studies, University of California.

HASENBALG, C. A., 1992. O negro na indústria, proletarização tardia e desigual. Ciências Sociais Hoje 1992, Rio de Janeiro: Anpocs.

HASENBALG, C. A. \& SILVA, N. V., 1988. Estrutura Social, Mobilidade e Raça. São Paulo: Vértice/Rio de Janeiro: Iuperj.

HASENBALG, C. A. \& SILVA, N. V., 1990. Raça e oportunidades educacionais no Brasil. Estudos Afro-Asiáticos, 18.

HASENBALG, C. A. \& SILVA, N. V., 1993. Notas sobre desigualdade racial e política no Brasil. Estudos Afro-Asiáticos. 25.

HOETINK, H., 1967. Caribbean Race Relations: A Study of Two Variants. Londres: Oxford University Press.

LAZO, A. C. G. V., 1988. A nupcialidade da população feminina negra, estado de São Paulo. Anais da Abep, 3.

LOVELL, P. A., 1989. Racial Inequality and the Brazilian Labor Market. Ph.D. dissertation, Gainesville: Universidade da Flórida.

LOVELL, P. A., 1992. Raça, classe, gênero e discriminação salarial no Brasil. Estudos AfroAsiáticos, 22.

MAGGIE, Y., 1989. Catálogo do Centenário da Abolição. Rio de Janeiro: Acec, Ciec/Núcleo da Cor/Universidade Federal do Rio de Janeiro.

OLIVEIRA, L. E. G. de et al., 1983. O Lugar do Negro na Força do Trabalho. Rio de Janeiro: IBGE.

PIERSON, D., 1942. Negroes in Brazil. Chicago: The University of Chicago Press.

PORCARO, R. M., 1988. Desigualdade racial e segmentação do mercado de trabalho. Estudos Afro-Asiáticos, 15.

ROSENBERG, F. M. de B. M., 1987a. Instrução, rendimento, discriminação racial e de gênero. Revista Brasileira de Estudos Pedagógicos, 68(159).

ROSENBERG, F. M. de B. M., 1987b. Relações raciais e rendimento escolar. Cadernos de Pesquisa, 63.

ROSENBERG, F. M. de B. M., 1990. Segregação espacial na escola paulista. Estudos AfroAsiáticos, 19. 
ROSENBERG, F. M. de B. M., 1991. Raça e educação inicial. Cadernos de Pesquisa, 77.

ROUT, L. B., 1976. The African Experience in Spanish America. Londres: Cambridge University Press.

SANSONE, L., 1992. Cor, classe e modernidade em duas áreas da Bahia. Estudos Afro-Asiáticos, 23.

SANSONE, L., 1993. Pai preto, filho negro. Trabalho, cor e diferenças de geração. Estudos Afro-Asiáticos, 25.

SANSONE, L., 1994. Nem somente preto ou negro. XIX Reunião da Associação Brasileira de Antropologia. Niterói: Universidade Federal Fluminense.

SCALON, M. C. R. da C., 1992. Cor e seletividade conjugal no Brasil. Estudos Afro-Asiáti$\cos , 23$.

SCHATTSCHNEIDER, E. E., 1960. The Semisovereign People. Hindsdale: The Dryden Press.

SEYFERTH, G., 1986. A estratégia do branqueamento. Ciência Hoje, 5(25).

SHERIFF, R., 1993. Woman/slave/saint: A parable of race, resistance and resignation from Rio de Janeiro, Brazil. Manuscrito inédito.

SILVA, D. F. da \& LIMA, M., 1992. Raça, gênero e mercado de trabalho. Estudos AfroAsiáticos, 23.

SILVA, N. do V., 1981. Cor e o processo de realização sócio-econômica. Dados, 24(3).

SILVA, N. do V., 1985. Updating the cost of not being white in Brazil. In: Race, Class and Power in Brazil (P. M. Fontaine, org.). Los Angeles: Center for Afro-American Studies, University of California.

SILVA, N. do V., 1987. Distância social e casamento inter-racial no Brasil. Estudos AfroAsiáticos, 14.

SILVA, N. do V., 1991. Estabilidade temporal e diferenças regionais no casamento inter-racial. Estudos Afro-Asiáticos, 21.

SILVA, N. do V. \& HASENBALG, C., 1993. Relações Raciais no Brasil Contemporâneo. Rio de Janeiro: Rio Fundo Editora.

SILVA, P. C., 1993. Negros à Luz dos Fornos: Representações de Trabalho e da Cor entre Metalúrgicos da Moderna Indústria Baiana. Dissertação de Mestrado, Salvador: Faculdade de Filosofia e Ciências Humanas, Universidade Federal da Bahia.

SKIDMORE, T. E., 1974. Black into White, Race and Nationality in Brazilian Thought. Nova Iorque: Oxford University Press.

TAMBURO, E. M. G., 1987. Mortalidade infantil da população negra brasileira. Textos Nepo, 11.

TAMBURO, E. M. G., 1991. Desiguais perante a morte. In: Desigualdades Raciais no Brasil Contemporâneo (P. A. Lovell, org.). Belo Horizonte: Cedeplar/Face/UFMG.

TANNENBAUM, F., 1946. Slave and Citizen. Nova Iorque: Alfred A. Knopf.

TELLES, E. E., 1990. Características sociais dos trabalhadores informais: O caso das regiões metropolitanas no Brasil. Estudos Afro-Asiáticos, 19. 
TELLES, E. E., 1993. Cor de pele e segregação residencial no Brasil. Estudos Afro-Asiáticos, 24.

TELLES, E. E., 1994. Industrialization and racial inequality in employment: The Brazilian example. American Sociological Review, 59.

WADE, P., 1993. Blackness and Race Mixture. The Dynamics of Racial Identity in Colombia. Baltimore: The Johns Hopkins University Press.

WOOD, C. H. \& CARVALHO, J. A. M., 1988. Racial inequality and child mortality: In: The Demography of Inequality in Brazil (C. H. Wood \& J. A. M. Carvalho, eds.). Cambridge: Cambridge University Press.

WRIGHT, W. R., 1990. Café con Leche, Race. Class and National Image in Venezuela. Austin: University of Texas Press. 


\section{ENDEREÇO DOS AUTORES:}

\section{Antonio Sérgio Alfredo Guimarães}

Departamento de Sociologia - Universidade Federal da Bahia, Estrada de São Lázaro, 197, Salvador, BA, 40230-600.

Endereço eletrônico: asergio@ufba.br

\section{Carlos Alfredo Hasenbalg} Instituto Universitário de Pesquisas do Rio de Janeiro (IUPERJ), Rua da Matriz,
82, Botafogo, Rio de Janeiro, RJ, 22260-100.

\section{Gilberto Hochman}

Departamento de Pesquisa - Casa de Oswaldo Cruz - Fundação Oswaldo Cruz, Avenida Brasil 4036, sala 401, Rio de Janeiro, RJ, $21040-361$.

Endereço eletrônico: hochman@dcc001.cict.fiocruz.br

\section{Giralda Seyferth}

Departamento de Antropologia - Museu Nacional - Universidade Federal do Rio de Janeiro, Quinta da Boa Vista s/n, São Cristóvão, Rio de Janeiro, RJ, 20940-040.

\section{Jair de Souza Ramos}

Departamento de Sociologia e Metodologia de Ciências Sociais - Instituto de Ciências Humanas e Filosofia - Universidade Federal Fluminense, Campus do
Gragoatá, s/n, Niterói, RJ, 24210-350.

\section{Joel Rufino dos Santos}

Fundação Palmares - Quadra 2, bloco F, Edifício Central Brasília, $1^{\circ}$ subsolo, Setor Bancário Norte, Brasília, DF, 70040-904.

\section{John Manuel Monteiro} Centro Brasileiro de Análise e Planejamento (CEBRAP), Rua Morgado de Mateus,
615, Vila Mariana, São Paulo, SP, 04015-902.

\section{Lívio Sansone} Departamento de Sociologia - Universidade Federal da Bahia. Estrada de São Lá-
zaro, 197, Salvador, BA, 40230-600.

Endereço eletrônico: sansone@ufba.br

\section{Lourdes Martínez-Echazábal}

Merrill College - University of California, Santa Cruz, CA, 95064, U.S.A.

Endereço eletrônico: lourdes@macmail.ucsc.edu

\section{Marcos Chor Maio}

Departamento de Pesquisa - Casa de Oswaldo Cruz - Fundação Oswaldo Cruz, Avenida Brasil 4036, sala 401, Rio de Janeiro, RJ, 21040-361.

Endereço eletrônico: maio@dcc001.cict.fiocruz.br 


\section{Maria Arminda do Nascimento Arruda}

Departamento de Sociologia - Faculdade de Filosofia, Letras e Ciências Humanas Universidade de São Paulo, Avenida Professor Luciano Gualberto, 315, Cidade Universitária, Caixa postal 8105, São Paulo, SP, 05508-900.

\section{Maria Lúcia de Santana Braga}

Departamento de Sociologia - Instituto de Ciências Humanas - Universidade de Brasília, Brasília, DF, 70910-900.

\section{Nísia Trindade Lima}

Departamento de Pesquisa - Casa de Oswaldo Cruz - Fundação Oswaldo Cruz, Avenida Brasil 4036, sala 401, Rio de Janeiro, RJ, 21040-361.

Endereço eletrônico: lima@dcc001.cict.fiocruz.br

\section{Omar Ribeiro Thomaz}

Centro Brasileiro de Análise e Planejamento (CEBRAP), Rua Morgado de Mateus, 615, Vila Mariana, São Paulo, SP, 04015-902.

\section{Ricardo Ventura Santos}

Departamento de Antropologia - Museu Nacional, Universidade Federal do Rio de Janeiro, Quinta da Boa Vista s/n, São Cristóvão, Rio de Janeiro, RJ, 20940-040. Endereço eletrônico: santos@dcc001.cict.fiocruz.br

\section{Yvonne Maggie}

Instituto de Filosofia e Ciências Sociais - Universidade Federal do Rio de Janeiro, Largo de São Francisco, 1, Rio de Janeiro, RJ, 20051-070. 


\section{OUTROS TÍTULOS DA EDITORA FIOCRUZ EM CATÁLOGO*}

- Estado sem Cidadãos: Seguridade Social na América Latina. Sônia Fleury, 1994. 249p.

- Saúde e Povos Indigenas. Ricardo Santos e Carlos E. A. Coimbra (orgs.), 1994. 251 p.

- Saúde e Doença: um olhar antropológico. Paulo César Alves e Maria Cecília de Souza Minayo (orgs.), 1994. 174p.

- Principais Mosquitos de Importância Sanitária no Brasil. Rotraut A. G. B. Consoli e Ricardo Lourenço de Oliveira, 1994. 174p.

- Filosofia, História e Sociologia das Ciências I: abordagens contemporâneas. Vera Portocarrero (org.). 1994. 268p.

- Psiquiatria Social e Reforma Psiquiátrica. Paulo Amarante (org.), 1994. 202p.

- O Controle da Esquistossomose. Segundo relatório do Comitê de Especialistas da OMS, 1994. 110p.

- Vigilância Alimentar e Nutricional: limitações e interfaces com a rede de saúde. Inês Rugani R. de Castro. 1995. 108p.

- Hanseniase: representações sobre a doença. Lenita B. Lorena Claro, 1995. 110p.

- Oswaldo Cruz: a construção de um mito na ciência brasileira. Nara Britto, 1995. $111 \mathrm{p}$.

- A Responsabilidade pela Saúde: aspectos juridicos. Hélio Pereira Dias. 1995. 68p.

- Sistemas de Saúde: continuidades e mudanças. Paulo M. Buss e Maria Eliana Labra (orgs.), 1995. 259p.

- Só Rindo da Saúde. Catálogo de Exposição Itinerante de mesmo nome, 1995. 52p.

- A Democracia Inconclusa: um estudo da Reforma Sanitária brasileira. Silvia Gerschman, 1995. 203p.

- Atlas Geografico de las Malformaciones Congenitas en Sudamérica. Maria da Graça Dutra (org.), 1995. 144p.

- Ciência e Saúde na Terra dos Bandeirantes: a trajetória do Instituto Pasteur de São Paulo no período 1903-1916. Luiz Antonio Teixcira. 1995. 187p.

- Profissões de Saúde: uma abordagem sociológica. Maria Helena Machado (org.). 1995. 193p.

- Recursos Humanos em Saúde no Mercosul. Organização Pan-Americana da Saúde, 1995. $155 \mathrm{p}$.

- Tópicos em Malacologia Médica. Frederico Simões Barbosa (org.). 1995. 314p.

- Agir Comunicativo e Planejamento Social: uma crítica ao enfoque estratégico. Francisco Javier Uribe Rivera, 1995. 213p.

- Metamorfoses do Corpo: uma pedagogia freudiana. Sherrine Njaine Borges, 1995. 197p.

- Política de Saúde: o público e o privado. Catalina Eibenschutz (org.), 1996. 364p.

- Formação de Pessoal de Nível Médio para a Saúde: desafios e perspectivas. Escola Politécnica de Saúde Joaquim Venâncio (org.), 1996. 222p.

- O Homem e a Serpente: outras histórias para a loucura e a psiquiatria. Paulo Amarante, 1996. $141 \mathrm{p}$.

- Tributo a Vênus: a luta contra a sifilis no Brasil. da passagem do século aos anos 40. Sérgio Carrara, 1996. 339p.

\section{PRÓXIMOS LANÇAMENTOS}

- Biossegurança: uma abordagem multidisciplinar. Pedro 'Teixeira e Silvio Valle (orgs.).

- Série Avanços e Perspectivas em Doenças Endêmicas.

- Série Conferências Mundiais da ONU.

* por ordem de lançamento/ano. 
IMPRESSÃO E ACABAMENTO

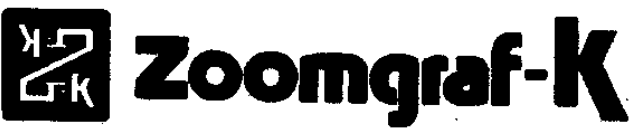

Av. Jansen de Mello, 403 - Niterói CEP: 24030-020 - RJ - Brasil - 1996

Tels.: PABX (021) 620-2277

Fax: 620-5619 